\title{
Upper Ordovician brachiopods from the Anderken Formation, Kazakhstan: their ecology and systematics
}

\author{
L.E. POPOV \\ Department of Geology, National Museum of Wales, Cardiff CF10 3NP \\ L.R.M. COCKS \\ Department of Palaeontology, The Natural History Museum, Cromwell Road, London SW7 5BD \\ I.F. NIKITIN \\ Institute of Geological Sciences, Almaty 480100, Kazakhstan
}

\section{CONTENTS}

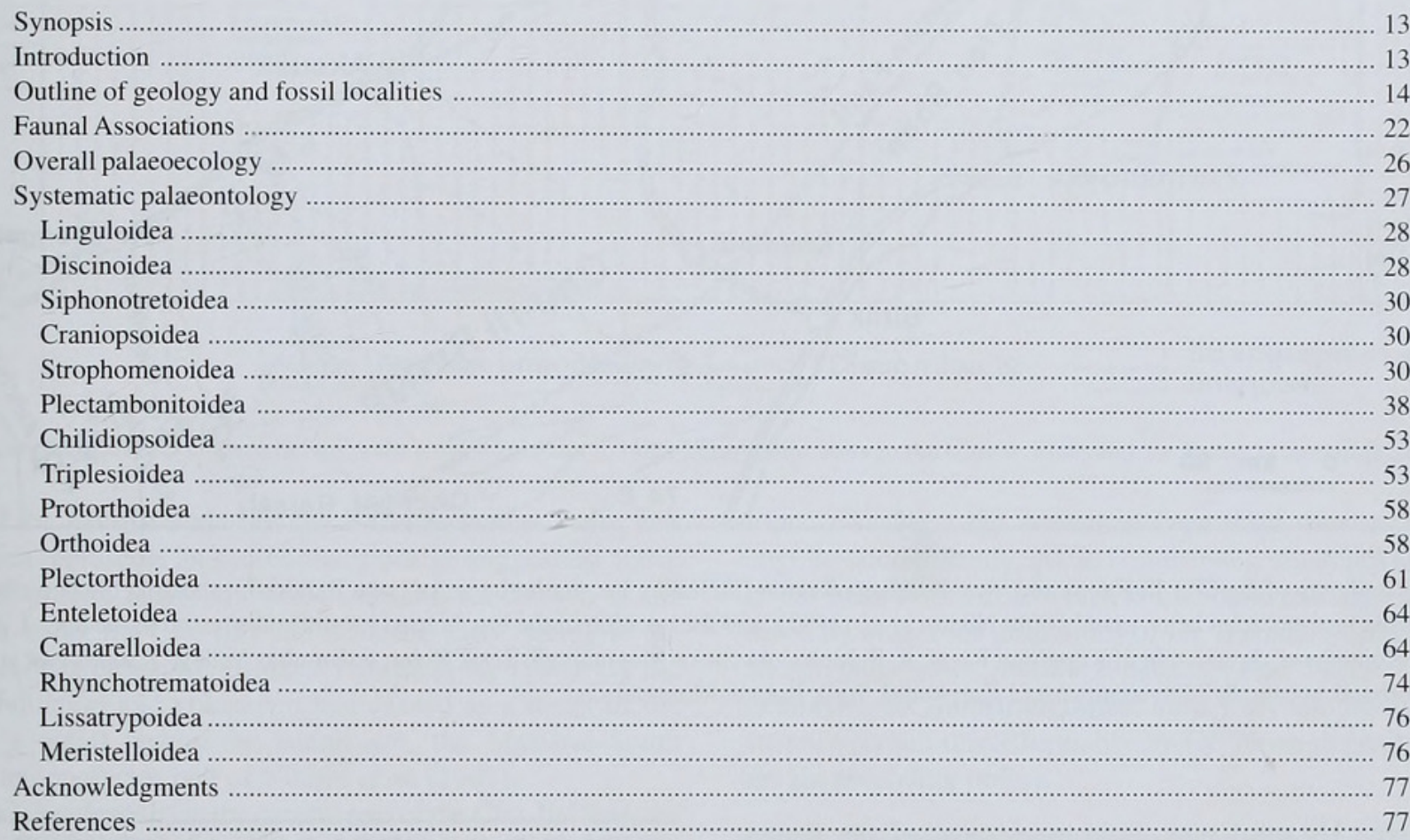

SYNOPSIS. The brachiopod fauna from the Anderken Formation (Lower to Middle Caradoc) of the Chu-Ili Range, south-eastern Kazakhstan, is revised and described systematically. It consists of 62 species in 55 genera, of which the genera Tesikella, Olgambonites and Zhilgyzambonites (all Plectambonitoidea) and Ilistrophina (Camarelloidea) are new, and the species Bellimurina (Bellimurina) sarytumensis, Teratelasmella chugaevae, Foliomena prisca, Acculina kulanketpesica, Dulankarella larga, Kajnaria rugosa, Anoptambonites convexus, Olgambonites insolita, Zhilgyzambonites extenuata, Gacella institata, Placotriplesia spissa, Grammoplecia wrighti, Dolerorthis pristina, Austinella sarybulakensis, Plectorthis? burultasica, Bowanorthis? devexa, Pionodema opima, Parastrophina iliana, Ilistrophina tesikensis, Liostrophia pravula, Plectosyntrophia unicostata, Rhynchotrema akchokense and Nikolaispira guttula are new. Six brachiopod-dominated assemblages are recognised and defined, termed the Ectenoglossa, Tesikella, Mabella-Sowerbyella, Acculina-Dulankarella, Parastrophina-Kellerella and Zhilgyzambonites-Foliomena Associations. The relationships with contemporary faunas are assessed, and the Anderken brachiopods appear to have much in common with those of north-west China.

\section{INTRODUCTION}

The global geography of the Lower Palaeozoic has been the subject of widespread international discussion in recent years (references in Cocks 2001), but much is not yet clear. In the Ordovician, the large area of what is today Kazakhstan was then divided into many separate crustal fragments of variable size. The relative positions of these fragments are contentious; some authors, notably Sengor \& Natalin (1996), consider that most of the fragments made up an enormous island arc, termed the Kipchak Arc, which stretched in a long curve all the way from the substantial craton of Baltica to the central Siberian Angaran craton. Others, for example Nikitin, have subdivided Kazakhstan in other ways, with a more conservative 


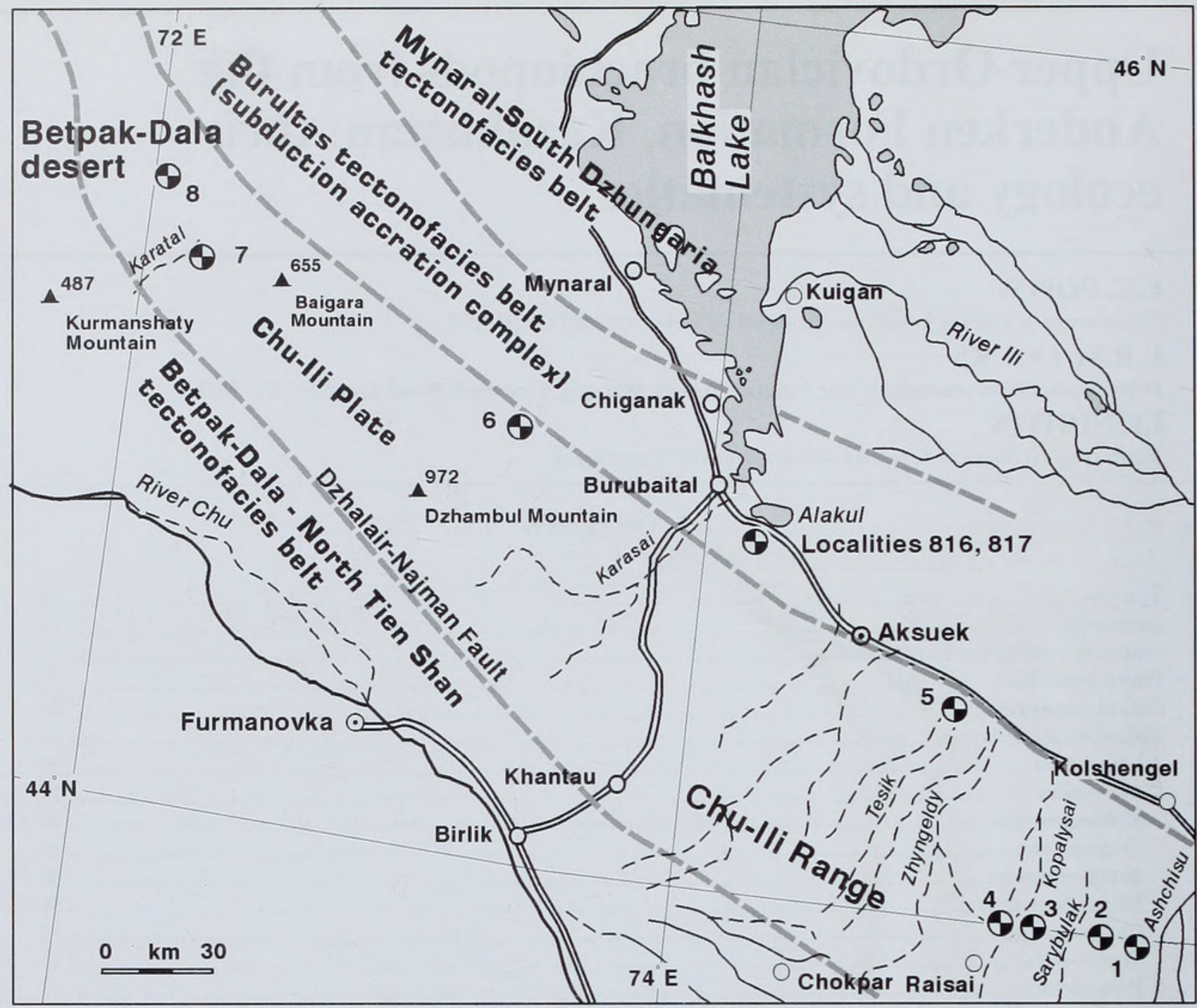

Fig. 1 Generalised map of the Chu-Ili Range and West Balkhash Region (including the southern part of Lake Balkhash), showing the boundaries of the Early Palaeozoic tectonofacies belts, mainly after Nikitin et al. (1991), and the position of the brachiopod localities discussed in the text: 1, AnderkenynAkchoku; 2, Kujandysai; 3, east side of Kopalysai River; 4, Buldubai-Akchoku Mountain; 5, Tesik River; 6, Burultas Valley; 7, south-east side of Karatal River near Sorbulak spring; 8, 7 km southwest of Karpkuduk Well, Kotnak Mountains.

palaeogeography. Up until now, little assessment of the faunas contained within these tectonic plates has been made, particularly in relationship to contemporary faunas from other areas. One such plate is that forming the Chu-Ili Range, and termed here the Chu-Ili Plate (Fig. 1). Within the Chu-Ili Plate the successions have been known for some time (e.g. Nikitin 1972, 1973). However, although a number of papers have been published on aspects of some of the contained Ordovician faunas, much remains to be done. A central formation within the unit is the Anderken Formation of early Caradoc age. This immediately underlies the Dulankara Formation, whose brachiopods from its lowest Otar Member we have recently revised (Popov et al.2000). Although some pioneering descriptions of some of the Anderken brachiopods were published by Rukavishnikova (1956) and some individual species have been published in a number of publications, e.g. Popov $(1980,1985)$ and Nikitin \& Popov (1983), the whole brachiopod fauna from the formation has never been published, and this is the chief purpose of the present paper. In addition, six brachiopod-dominated associations can be identified from the Anderken Formation. LEP and LRMC are responsible for the whole paper and IFN for input into the systematic palaeontology and biofacies sections.

\section{OUTLINE OF GEOLOGY AND FOSSIL LOCALITIES}

The Chu-Ili Plate (Fig. 1), as recognised here, is a small part of Asia today, and is traceable from the Zailiyskiy Alatau Range in the southeast to the northern Betpak-Dala Desert in the northwest, where it disappears under late Palaeozoic and Mezo-Cenozoic deposits. To the southwest it is bordered by the large Dzhalair-Najman Fault and northward-dipping homoclinal sequences of Upper Cambrian and Lower to Middle Ordovician age which are mainly siliciclastic slope rise deposits (e.g. the Dzhambul Formation), indicating passive margin development, and several thrust sheets consisting of dismembered ophiolites of the early Palaeozoic Ashchisu Formation (Toporova et al. 1971). The Dzhalair-Najman Fault mainly follows an early Palaeozoic suture which separates the Lower Palaeozoic Chu-Ili Plate from the Middle to Upper Ordovician volcanic island-arc association traceable along the northeastern margin of the Betpak-Dala-North Tien Shan tectonofacies belt of Nikitin (Nikitin et al.1991), which is the same as the DjezkazaanKirgiz (4.1) tectonofacies unit of Sengör \& Natalin (1996). To the 


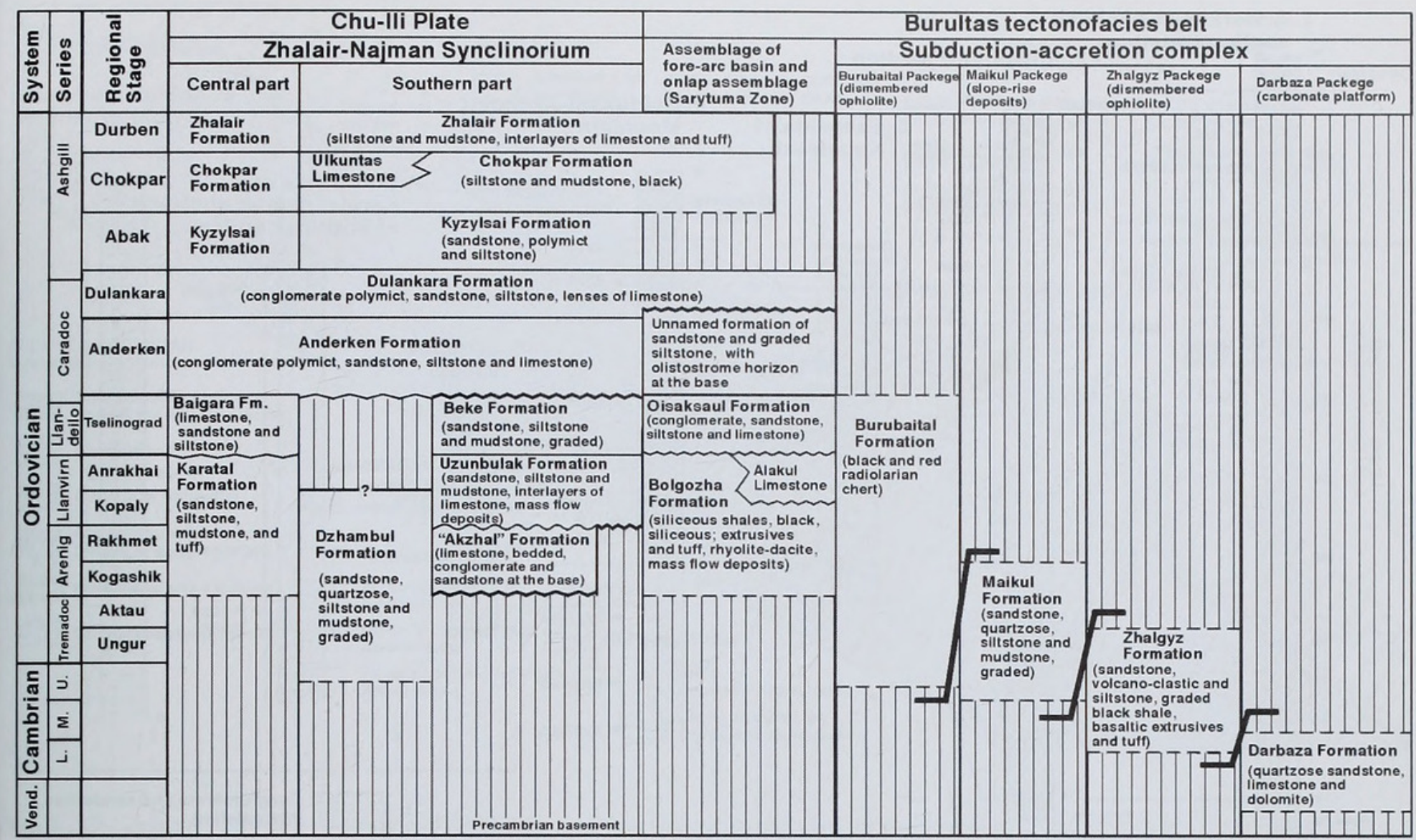

\section{$\oiiint$ Angular unconformity $\leadsto$ Discontinuity $=--\begin{aligned} & \text { Stratigraphic contact } \\ & \text { unknown }\end{aligned}$}

Fig. 2 Chart showing the correlation between the Lower Palaeozoic lithostratigraphic units in the Chu-Ili Plate and the Burultas tectonofacies belt.

north-east of the Chu-Ili Plate lies the Burultas tectonofacies belt (Fig. 2), which represents an accretionary wedge suggesting active margin development, island arc volcanism and subduction of the oceanic crust under the Chu-Ili Plate from the early Arenig to the Llandeilo Pygodus anserinus Biozone (Koren et al. 1993). By the Caradoc, subduction and volcanism had ceased as a result of the docking of a small terrane or island arc, the Mynaral-South Dzhungaria tectonofacies belt of Nikitin et al. (1991).

The Ordovician deposits in the central part of the Chu-Ili Plate, the Dzhalair-Najman Synclinorium, form a nearly continuous sequence of siliciclastic and carbonate rocks from Arenig to Ashgill in age (Fig. 2), which are relatively unmetamorphosed and chiefly dip gently to the northeast. They are covered conformably by Silurian deposits (Nikitin et al. 1980) or unconformably by the Devonian. The Ordovician stratigraphy and major lithostratigraphic units were described by Keller (1956) and Nikitin (1972).

The Lower to Middle Caradoc deposits, which are the main source of the brachiopods described here, are termed the Anderken Formation, which is a transgressive sequence of mainly siliciclastic deposits that contain variably developed lens-like carbonate units in the upper part representing mud mounds or algal build-ups (Nikitin et al. 1974; 1996). They are best developed in the following eight general localities (Figs 1, 3):

\section{Localites 1-2. Area between the Ashchisu and Sarybulak rivers.}

In the south-eastern part of the Chu-Ili Range the best sections of the Anderken Formation are located in a block with faulted margins between the rivers Ashchisu and Sarybulak (Fig. 1, localities 1-2;
Figs 3,4). Here the Anderken Formation overlies, with a slight angular unconformity, graded sandstones, siltstones and mudstones of the Beke Formation, which is Llandeilo to early Caradoc in age, dated by numerous graptolites of the Hustedograptus teretiusculus and Nemagraptus gracilis Biozones (Tsai 1976). The Anderken comprises six lithostratigraphic units traceable up to $40 \mathrm{~km}$ along strike, overlain unconformably by Devonian deposits. These units are (in ascending order):

Unit 1. Polymict, pebbly conglomerate, with sandy matrix and with some beds of sandstone and gritstone. Thickness from $45 \mathrm{~m}$ to 120 $\mathrm{m}$, with maximum values in the Anderkenyn-Akchoku section.

Unit 2. Coarse- to medium-grained sandstone with subhorizontal stratification alternating with abundant cross-bedded sets. Lenses of polymict, pebbly conglomerate represent shallow channels formed by tidal currents. Thickness varying from $52 \mathrm{~m}$ in the Kujandysai section in the west to $180 \mathrm{~m}$ in the Anderkenyn-Akchoku section (Figs 3, 5). The upper part contains the lingulide Ectenoglossa sorbulakensis, the trilobite "Isotelus" romanovskyi Weber and gastropods (Samples 8130-1, 7612). The middle part of the unit in the Anderkenyn-Akchoku section contains a carbonate mud-mound up to $16 \mathrm{~m}$ thick with a core built of light grey micritic limestone. On the flanks there is bedded biomicrite with the brachiopods Skenidioides sp., Christiania sp. and Kellerella misiusi, the trilobites Mesotaphraspis spinosus Lisagor, Selenoharpes sp., Acrolichas sp. Eokosovopeltis romanovskyi and Sphaerexochus aff. hisingeri Warburg. Illaenus sp. was noted from about 1.0-1.5 m below the top of the mud-mound in the eastern part of its exposure (Sample 8226). Cystoid and crinoid columnals are abundant. 


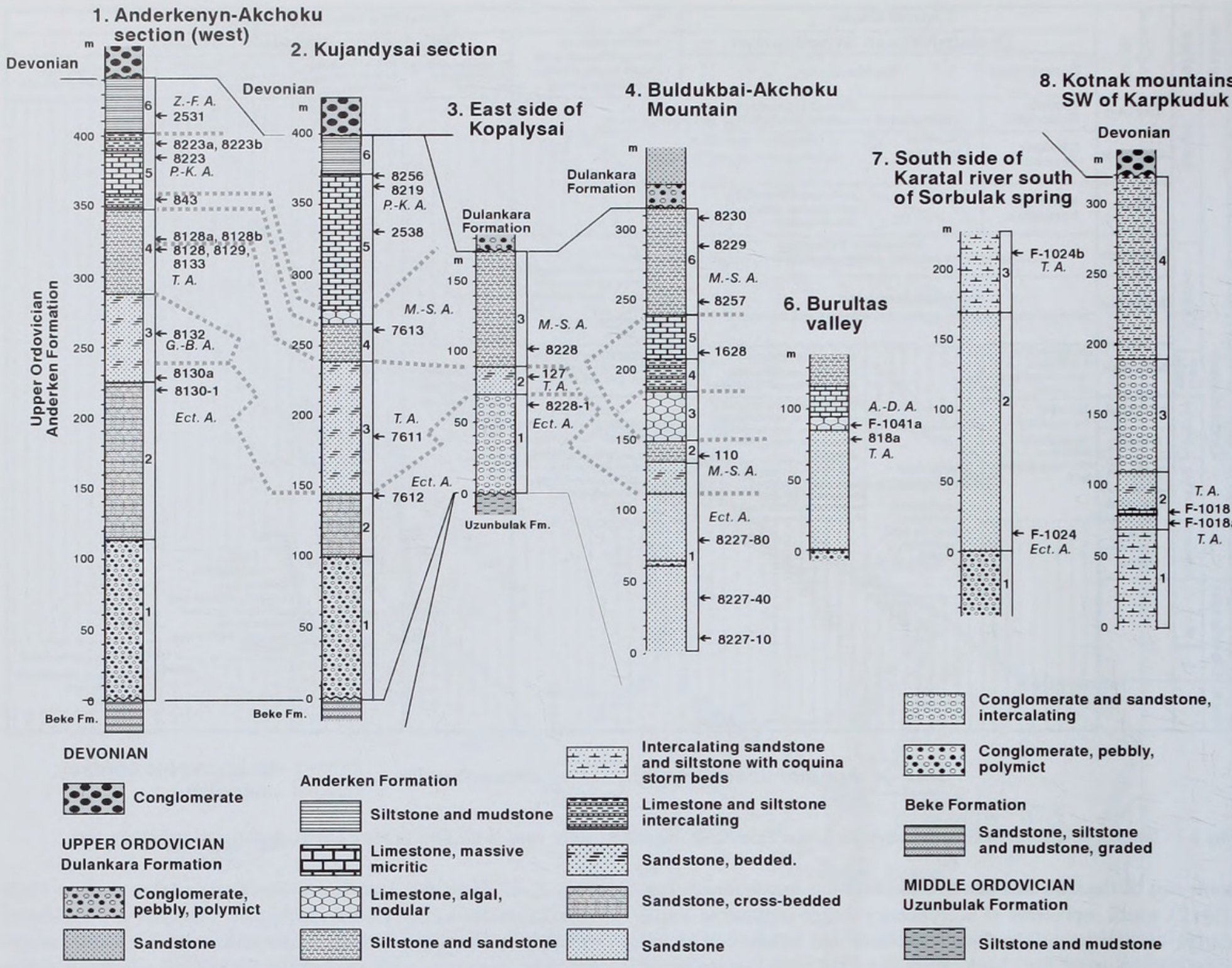

Fig. 3 Columnar sections through the Anderken Formation showing informal units, stratigraphic positions of samples and brachiopod associations: Ect. A.Ectenoglossa Association, T. A., Tesikella Association, M.-S. A., Mabella-Sowerbyella Association, A.-D. A., Acculina-Dulankarella Association, P.-K. A., Parastrophina-Kellerella Association, Z.-F. A., Zhilgyzambonites-Foliomena Association, G.-B. A, Gastropod-Bivalved Molluscs Association. The numbers of the sections are the same as those on Fig. 1.

Unit 3. Coarse- to medium- grained sandstone with mostly subhorizontal stratification, about 40-62 m thick in the AnderkenynAkchoku section and up to $97 \mathrm{~m}$ thick in the Kujandysai section, with some storm beds of coquinas up to $20 \mathrm{~cm}$ thick with concentrations of gastropods and the disarticulated bivalved molluscs Edmondia fecunda Khalfin, Ctenodonta sp. and Orthonota? sp. (Sample 8130a). Gastropods, bivalved molluscs and the trilobite Eokosovopeltis romanovskyi become increasingly abundant in the flank deposits in the upper $20 \mathrm{~m}$ of the unit (Samples 8130,8134 ). In the Kujandysai section concentrations of bivalved molluscs occur in the middle part in association with the rare brachiopod Tesikella necopina and the pelmatozoan columnals Clivosocystis clivosus Stukalina and Ordinacrinus punctatus Stukalina (Sample 7611).

Unit 4. Medium- to fine-grained sandstone replaced gradually upwards by siltstone with numerous trace fossils and symmetrical ripple marks. Thickness varies from 22 to $80 \mathrm{~m}$ in the AnderkenynAkchoku section and is about $28 \mathrm{~m}$ in the Kujandysai section. The lower part contains local concentrations of the coalified plant Akdalaphyton caradoci Senkevich, and gastropod and bivalved mol- luscs in association with the brachiopod Tesikella necopina (Samples $8127-2 b, 8129,8133,8138$ ). The upper part contains an abundant brachiopod fauna of the Sowerbyella-Mabella Association (Samples 100b, 7613, 8128a, 8128b, 8135, 8137) and the trilobites Dulanaspis laevis anderkensis Chugaeva, Lonchodomas tecturmasi Weber, Pliomerina sp., Remopleurides sp., Styginella macrophtalma Pribyl \& Vanek, Bronteopsis extraordinaris Chugaeva, the cystoid and crinoid columnals Clivosocystis clivosus, Digiticrinus levis Stukalina, Ordinaricrinus punctatus Stukalina and Communicrinus communis Stukalina and the starfish Stenaster obtusus (Forbes).

Unit 5. Limestones varying in thickness from 8 to $98 \mathrm{~m}$ forming a chain of carbonate build-ups between the Uzunbulak and the Ashchisu rivers (Fig. 3). The cores of these build-ups rest on a bed of nodular limestone from $2-10 \mathrm{~m}$ thick with abundant dasyclad algae Cyclocrinites nikitini Gnilovskaya and Mastopora reticulata Gnilovskaya (Nikitin et al. 1974). A bed of nodular, algal limestone with dasyclad algae is usually present in the interspaces between the carbonate build-ups and contains brachiopods of the AcculinaDulankarella Association (Samples 100, 8251, 85258), the rare 


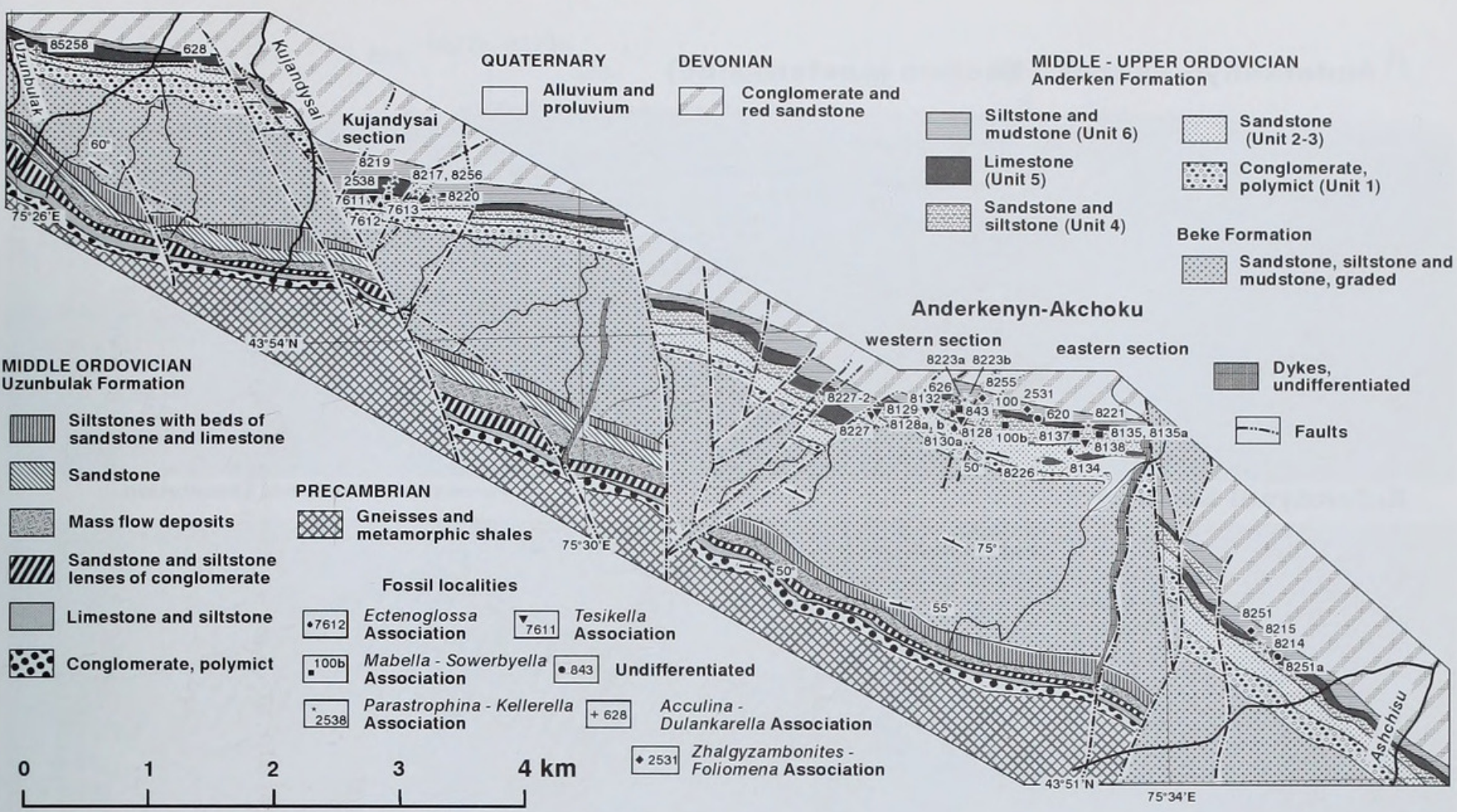

Fig. 4 Geological map showing distribution of the Middle and Upper Ordovician rocks and the positions of measured sections and fossil localities that yielded brachiopods in the area between the Uzunbulak and Ashchisu Rivers, south-eastern Chu-Ili Range (after Nikitin 1972, modified).

tabulate corals Lichenaria? sp. and Amsassia sp., stromatoporoids, and various trilobites and echinoderms. Locally between the Kujandysai and Sarybulak rivers, and on both sides of the Ashchisu River in the eastern part of outcrop area, carbonate build-ups disappear and the unit comprises bedded limestone varying from biomicrite to biosparite intercalating with siltstone and mudstone, with brachiopods of the Parastrophina-Kellerella Association (Tables 4 5 , Samples $628,8223,8223 \mathrm{a}, 8223 \mathrm{~b}$ ). Brachiopods of this association also occur in pockets of bioclastic limestone in the mud-mound core and the overlying bedded limestone together with large spherical or ellipsoidal ooids of radiaxial calcite up to $1 \mathrm{~cm}$ across (Samples $2538,8217,8219,8256)$.

Unit 6. Siltstone and mudstone with up to 6 interlayers of bentonite up to $0.3 \mathrm{~m}$ thick in the lower part, total about $50-60 \mathrm{~m}$ thick, containing brachiopods of the Zhilgyzambonites-Foliomena Association (Samples 8231, 8251, 8255). Abundant trilobites are Granulatagnostus granulatus Kolobova, Sphaeragnostus sp., Microparia speciosa Hawle \& Corda, Hammatocnemis sp., Birmanites almatiensis (Chugaeva), Cyclopyge sp., Cybele weberi Chugaeva and Ovalocephalus sp., and graptolites include Dicranograptus nicholsoni, Diplograptus anderkenensis, Glyptograptus trubinensis and Pseudoclimacograptus scharenbergi, suggesting the Lower to Middle Caradoc Diplograptus multidens Biozone (Keller 1956).

\section{Locality 3. East side of Kopalysai River}

On the east side of the Kopalysai River (Fig. 1) the Anderken Formation is about $160 \mathrm{~m}$ thick and rests unconformably on the siliciclastic Llandeilo Beke Formation (Fig. 2). Detailed description of this section was provided by Keller (1956: 26), who recognised three units (Fig. 3): (1) bed of intercalating polymict conglomerate and coarse- to medium-grained sandstone up to $70 \mathrm{~m}$ thick with bivalves, rare Ectenoglossa sorbulakensis (Sample 8223-1) and numerous plant remains of Akdalaphyton caradoci; (2) intercalating fine-grained sandstone and siltstone about 15-20 m thick with brachiopods of the Tesikella Association (Sample 127), the trilobites Dulanaspis levis anderkensis and Lonchodomas tecturmasi; and (3) mudstones with some siltstones and fine-grained sandstones about 70-80 $\mathrm{m}$ thick with abundant brachiopods of the MabellaSowerbyella Association (Sample 8228). The deposits overlying the Anderken Formation are polymict pebbly conglomerates and sandstones of the Dulankara Formation.

\section{Locality 4. Buldukbai-Akchoku Mountain}

On the west side of the River Kopalysai, the Anderken Formation includes a large carbonate mud-mound which forms the top of Buldukbai-Akchoku Mountain. The lower part of the formation is exposed on the south-western slope of the mountain, north of an eastwest fault (Figs 1, 3, 5-7). It includes, in ascending order:

Unit 1. Medium- to fine-grained sandstone up to $120 \mathrm{~m}$ thick with Ectenoglossa sorbulakensis.

Unit 2. Dark green, bedded siltstones, about $14 \mathrm{~m}$ thick with a few layers of fine grained sandstone $3-10 \mathrm{~cm}$ thick, containing Mabella conferta and Shlyginia fragilis of the Sowerbyella-Mabella Association.

Unit 3. Siltstones with nodules of algal limestone gradually changing into beds of nodular limestone with dasyclad algae towards the top, $38 \mathrm{~m}$ thick in total.

Unit 4. Nodular algal limestone intercalating with siltstone about $0.5-1.5 \mathrm{~m}$ thick, up to $22 \mathrm{~m}$ thick in total, with brachiopods of the Acculina-Dulankarella Association (Sample 8231-40). 


\section{Anderkenyn-Akchoku Section (eastern side)}

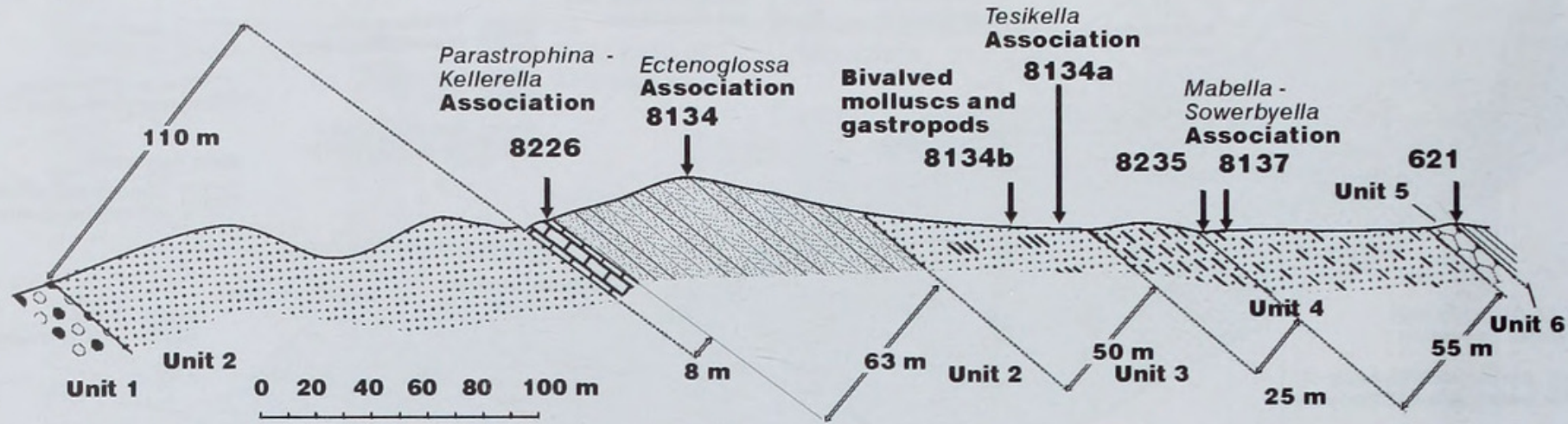

\section{Kujandysai Section}

Parastrophina - Kellerella Association

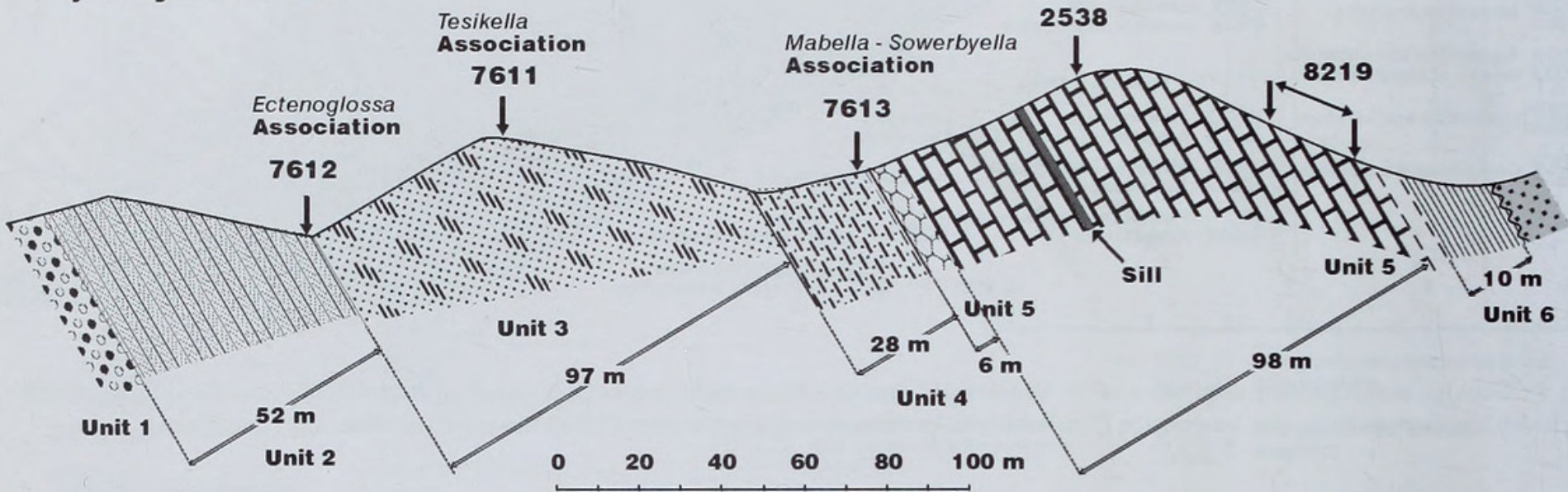

Buldukbai-Akchoku Section

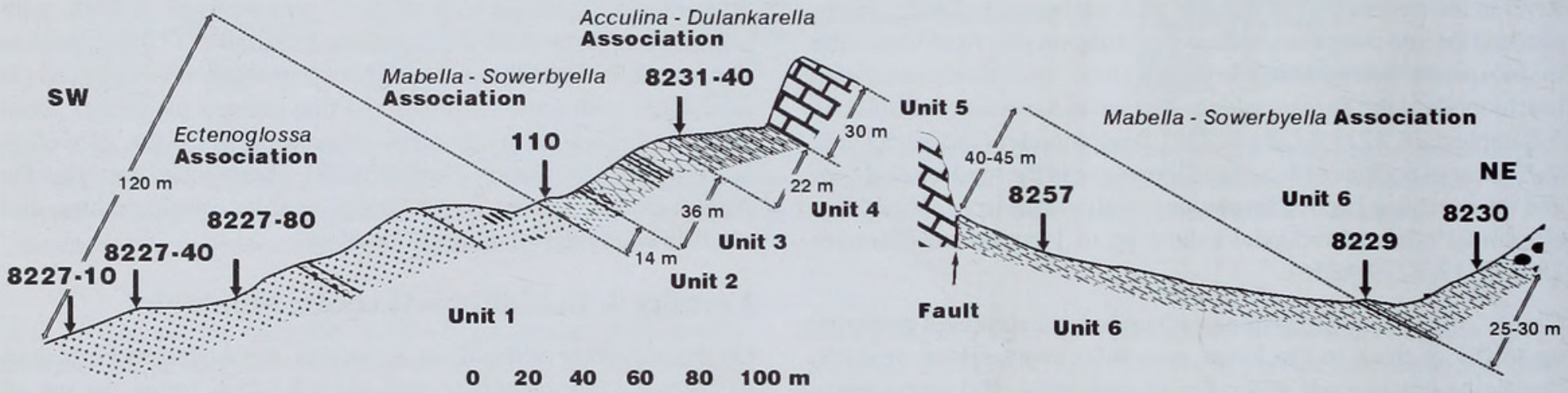

DEVONIAN

$\therefore \because \because \because$ Conglomerate

UPPER ORDOVICIAN

Dulankara Formation

Conglomerate, pebbly, polymict
Anderken Formation

Siltstone and mudstone

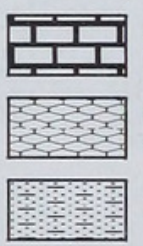

Limestone, massive

micritic

Limestone, algal, nodular

Siltstone

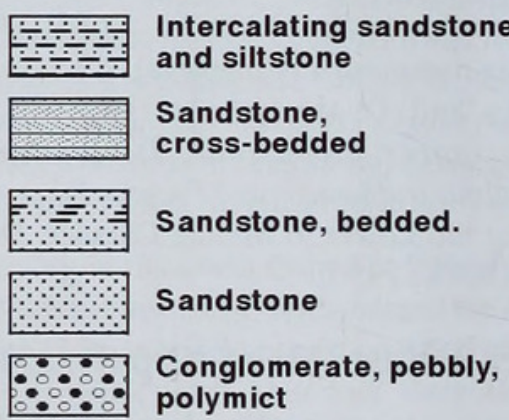

Fig. 5 Schematic stratigraphic sections of the Anderken Formation in the Chu-Ili Range, showing the position of samples and distribution of brachiopod associations. 

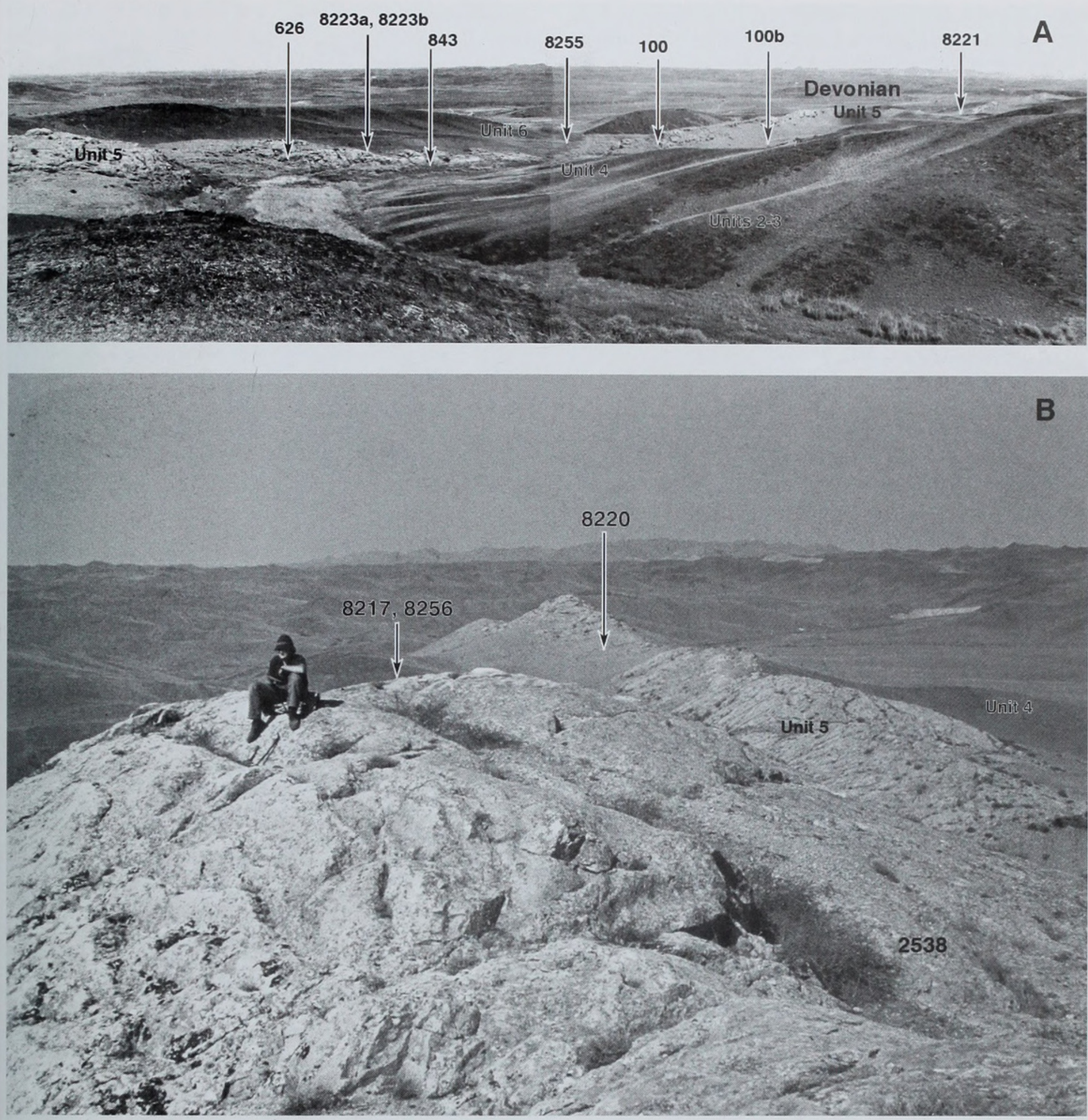

Fig. 6 A, general view of the Anderken Formation at the Anderkenyn-Akchoku section, showing informal lithostratigraphic units discussed in the text and the position of brachiopod localities. B, view of large complex carbonate buildup at Akchoku Mountain in the upper part of the Kujandysai section. Photographs by Igor Nikitin.

Unit 5. Massive micritic limestone forming the core of the carbonate mud-mound at the top of the mountain, about $30 \mathrm{~m}$ thick.

The upper part of the Anderken Formation outcrops along the north-eastern slope of Buldukbai-Akchoku Mountain. It includes:

Unit 6. Laminated, dark green siltstone up to $70 \mathrm{~m}$ thick with storm beds of calcareous sandstone rich in brachiopod coquinas about 10 $15 \mathrm{cms}$ thick and crinoid columnals. The top is a characteristic bed of laminated brownish-violet siltstone about $0.5 \mathrm{~m}$ thick overlain by polymict conglomerate of the Dulankara Formation (Fig. 7B). The unit contains numerous coalified plant remains of Akdalaphyton caradoci concentrated on several bedding surfaces, brachiopods of the Sowerbyella-Mabella Association (Samples 8229, 8230) and the echinoderms Clivosocystis sp., Digitocrinus levis and Ristnacrinus bifidus Stukalina.

\section{Locality 5. Tesik River}

This locality is on the southern side of the River Tesik about $1.5 \mathrm{~km}$ upstream of the bridge crossing the river on the highway from 

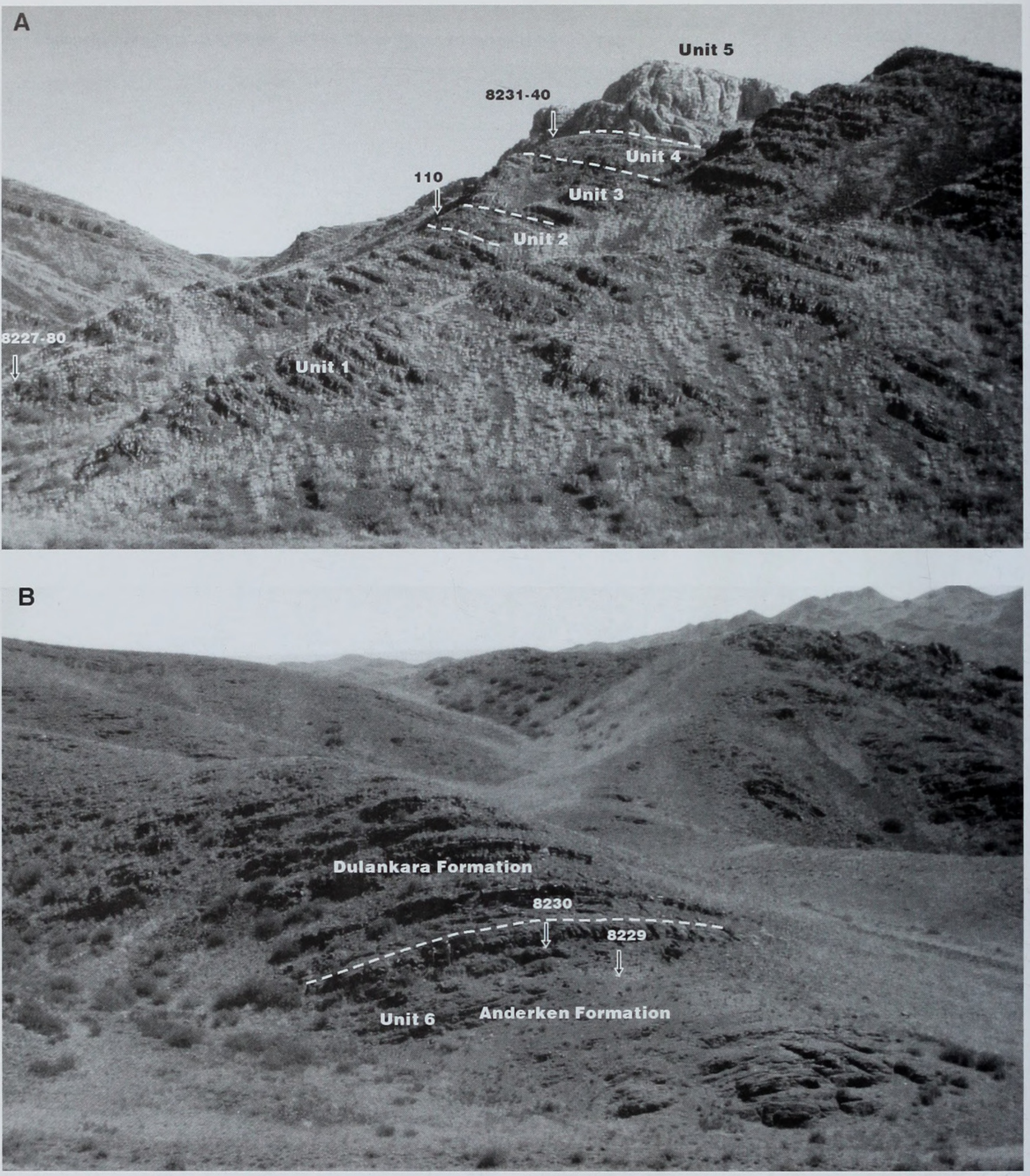

Fig. 7 The Anderken Formation on the south-western slope of Buldukbai-Akchoku Mountain. A, Units 1 to 5, and Sample localities 8227-80, 110 and 8231-8240; B, Unit 6 and the contact with the overlying Dulankara Formation and Sample localities 8229 and 8230 . Photographs by Lars Holmer.

Almaty to Balkhash (Fig. 1, locality 5). It is an isolated natural exposure of about $20 \mathrm{~m}$ of pink to light red rocks of massive micritic limestone forming the core of a mud-mound with lenslike beds of biosparite at the base of the exposure. Most of the bioclasts are fragmented large cystoid columnals. It contains an abundant Parastrophina-Kellerella Association (Sample 948).

\section{Locality 6. Burultas Valley}

The Burultas Valley (Fig. 1, locality 6) is about $42-45 \mathrm{~km}$ west of Chiganak on the western Balkhash coast (northeastern part of 
Quadrangle $73^{\circ} 22^{\prime} 30^{\prime \prime}$ to $73^{\circ} 30^{\prime} \mathrm{E} ; 4^{\circ}$ to $45^{\circ} 05^{\prime} \mathrm{N}$ ). A summary of the Ordovician geology and lithostratigraphy of this locality is in Nikitin et al. (1980, text-figs 18, 20). The Anderken Formation consists mainly of siliciclastic rocks with a thick unit of polymict conglomerates at the base and a number of carbonate mud-mounds in the upper part (Fig. 3). The carbonate unit in the top of the sequence is a bed of nodular algal limestone about 6-10 m thick with numerous Girvanella sp., Cyclocrinites nikitini and Mastopora reticulata and brachiopods of the Acculina-Dulankarella Association (Locality 1041a of Nikitin = Sample 390/76 of Kovalevskii), which underlies a lens of massive, micritic limestone up to $20 \mathrm{~m}$ thick which forming the mud-mound core. The unit thins about 200 m westward from Locality $1041 \mathrm{a}$, where it is represented by bedded and nodular limestone with the brachiopods Pionodema opima, Dulankarella larga and Mabella conferta (Sample 818). The uppermost $10 \mathrm{~m}$ of the underlying unit, of fine-grained sandstone intercalating with siltstone, contains a different brachiopod assemblage with Tesikella necopina (Sample 818a), in association with abundant cystoid columnals.

\section{Locality 7. Sorbulak spring on the east side of the River Karatal}

In the south Betpak-Dala Desert, about $20 \mathrm{~km}$ west of Baigara Mountain, the Anderken Formation is well exposed on both sides of the River Karatal (Fig. 1, locality 7). Here it rests on the graded sandstones and siltstones of the Llandeilo to Lower Caradoc upper Baigara Formation (Fig. 2), or is in contact with intrusives. About 2 $\mathrm{km}$ south-east of the Karatal river, south of Sorbulak spring, it comprises (1) polymict conglomerates more than $50 \mathrm{~m}$ thick, (2) medium- to fine-grained sandstones 169-170 m thick with Ectenoglossa sorbulakensis about $10-15 \mathrm{~m}$ above the base of the unit (Fig. 3, Sample 1024); and (3) intercalating fine-grained slightly calcareous sandstones and siltstones about $60 \mathrm{~m}$ thick with the Tesikella Association in the upper $20 \mathrm{~m}$ of the unit. The upper part of the section is an unfossiliferous unit of intercalating fine-grained sandstones, lilac and red siltstones and mudstones several hundred metres thick, which is overlain by the basal conglomerate of the Dulankara Formation.

\section{Locality 8. Kotnak Mountains}

This incomplete section of the Anderken Formation is situated west of the Kotnak Mountains, about 7 km SW of Karpkuduk Well. There, about $1.5 \mathrm{~km}$ north-east of the salt marsh (Figs 1,3,8), the formation consists of: (1) siltstone about $70 \mathrm{~m}$ thick with some storm beds of calcareous sandstone about $10-20 \mathrm{~cm}$ thick with a coquina of the bivalve Ctenodonta sp. (Samples 1017, 1019); (2) sandstone intercalating with siltstone in the upper part, total $40 \mathrm{~m}$ thick, with brachiopods of the Tesikella Association in the lower $10 \mathrm{~m}$ of the unit

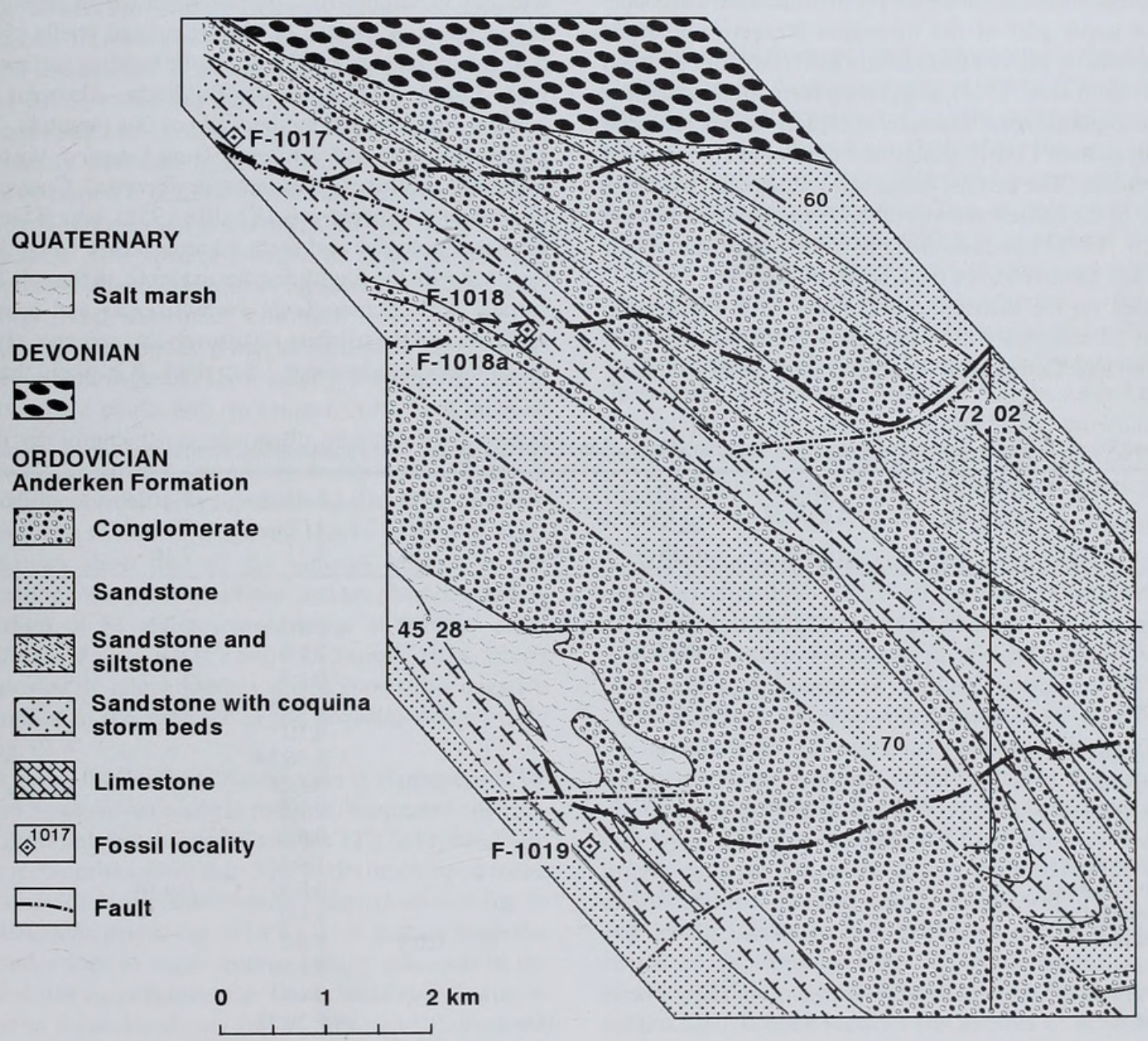

Fig. 8 Geological map showing the distribution of the Anderken Formation and the position of fossil localities in the area about $7 \mathrm{~km}$ south-west of Karpkuduk well, Kotnak Mountains. 
Table 1 Composition of Ectenoglossa Association from the Anderken Formation showing number of complete shells, ventral and dorsal valves respectively.

\begin{tabular}{llllllll}
\hline Sample number & 7612 & $8130 \mathrm{a}$ & $8130-1$ & $8223-1$ & $8227-10$ & $8227-40$ & $8227-80$ \\
Number of specimens & 27 & 1 & 2 & 1 & 6 & 4 & 3 \\
Ectenoglossa sorbulakensis & $24: 3: 2$ & $0: 1: 0$ & $0: 2: 0$ & $0: 1: 1$ & $6: 0: 0$ & $0: 3: 4$ & $0: 3: 3$ \\
\hline
\end{tabular}

(Sample 1018a) below a bed of skeletal calcareous sandstone about $5 \mathrm{~m}$ thick with an allochthonous brachiopod fauna with a mixture of taxa of the Tesikella and Mabella-Sowerbyella Associations (Sample 1018); (3) intercalating beds of sandstone and pebbly polymict conglomerate about 80-90 m thick; and (4) siltstone with a few beds of fine-grained sandstone, total $130 \mathrm{~m}$ thick and overlain unconformably by Devonian conglomerate.

\section{FAUNAL ASSOCIATIONS}

The Anderken Formation is a transgressive sequence from near shore to outer shelf deposits with predominantly siliciclastic deposition. The lower part of the formation, below the main horizon with carbonate build-ups in theAnderkenyn-Akchoku, Kujandysai, Buldukbai-Akchoku and Burultas sections, was formed in tidedominated environments of mostly tidal flat deposits with characteristic sets of pebbly conglomerates, cross-bedded and laminated sands, coquina storm beds and traces of tidal currents. Carbonate build-ups in the upper part of the formation preserve numerous traces of photosynthetic activity and contain a diverse flora of green and red algae (Nikitin et al. 1974); suggesting formation in shallow depths within the euphotic zone. The outer shelf deposits are recorded only in the south-eastern Chu-Ili Range and consist of silt and mud containing graptolites. The benthic fauna is dominated by trilobites but includes one of the earliest records of the Foliomena brachiopod fauna. Apollonov (1975) has described the trilobite associations of the middle and late Ordovician of the Chu-Ili Plate.

A matrix based on the distribution of about 1800 brachiopod specimens from 33 samples within the Anderken Formation was subjected to Principal Component Analysis (Etter 1999). Plots of eigenvectors corresponding to three maximum directions of variation (F1-F3) are illustrated on two two-dimensional diagrams (Fig. 9). The Diversity Index is calculated as the number of species minus 1 divided by the natural logarithm of the number of brachiopod individuals in the sample (for details see Williams et al. 1981). The analysis of taxonomic composition and relative abundance of brachiopod taxa from numerous localities and samples in the Anderken Formation allows recognition of six brachiopod associations characterised below. They are interpreted within the Benthic Assemblage (BA) scheme of Boucot (1975).

1. The Ectenoglossa Association. This is a monospecific lingulide association of BA-1 with Ectenoglossa sorbulakensis in the Anderkenyn-Akchoku, Kujandysai and Buldukbai-Akchoku sections, the east side of the Kopalysai River and on the southern side of the Karatal River south of Sorbulak spring (Table 1). The assemblage shows patchy distribution in lithologies of coarse- to mediumgrained sands with subhorizontal and cross-bedded stratification. In most of the localities shells are disarticulated on the bedding surfaces and only in Sample 7612 do conjoined valves predominate $(89 \%$ of individuals). A cluster of six articulated shells preserved in life position inclined from $62^{\circ}-80^{\circ}$ to the bedding surface was recovered from Sample 8227-40 in the Buldukbai-Akchoku section, which confirms the infaunal mode of life of this lingulide. The gastropods Lophospira sp. and Latitenia kasachstanica Vostokova and the bivalved molluses Endomionia fecinda, Ctenodonta sp. and Cyrtodonta? subcentralis (Khalfin 1958), which are widespread in similar lithologies and form coquina storm beds, do not co-occur together with the lingulides; for example, in Sample 8130 a bedding surface with Ectenoglossa sorbulakensis and a storm bed with molluscs and the trilobite Eokosovopeltis romanovskyi are separated by an interval only about $2.5 \mathrm{~m}$ thick. It is likely that Ectenoglossa

Table 2 Composition of Tesikella Association from the Anderken Formation showing number of complete shells, ventral and dorsal valves respectively.

\begin{tabular}{|c|c|c|c|c|c|c|c|c|c|}
\hline $\begin{array}{l}\text { Sample numbers } \\
\text { Number of specimens } \\
\text { Diversity index }\end{array}$ & $\begin{array}{l}127 \\
18 \\
0.33\end{array}$ & $\begin{array}{l}818 a \\
22 \\
0.65\end{array}$ & $\begin{array}{l}\text { F-1018a } \\
32 \\
0.58\end{array}$ & $\begin{array}{l}7611 \\
7 \\
0.51\end{array}$ & $\begin{array}{l}8128 \\
18 \\
1.38\end{array}$ & $\begin{array}{l}\text { F-1018 } \\
172 \\
3.11\end{array}$ & $\begin{array}{l}\text { F-1024b } \\
20 \\
2.16\end{array}$ & $\begin{array}{l}8127-2 b \\
1\end{array}$ & $\begin{array}{l}8138 \\
2\end{array}$ \\
\hline $\begin{array}{l}\text { Trematis sp. } \\
\text { Tesikella necopina } \\
\text { Longvillia lanx } \\
\text { Glyptomena onerosa } \\
\text { Christiania egregia } \\
\text { Limbimurina sp. } \\
\text { Isophragma imperator } \\
\text { Acculina kulanketpesica } \\
\text { Mabella conferta } \\
\text { Shlyginia fragilis } \\
\text { Anaptambonites orientalis } \\
\text { Sowerbyella rukavishnikovae } \\
\text { Bicuspina rukavishnikovae } \\
\text { Plectorthis burultasica } \\
\text { Dolerorthis expressa } \\
\text { Phragmorthis conciliata } \\
\text { Eodalmanella extera } \\
\text { Pionodema opima } \\
\text { Rhynchotrema } \text { sp. nov. } \\
\text { Didymelasma cf. transversa }\end{array}$ & $\begin{array}{l}0: 0: 1 \\
3: 14: 12\end{array}$ & $0: 13: 12$ & $\begin{array}{l}0: 16: 7 \\
0: 4: 5\end{array}$ & $1: 5: 5$ & $0: 0: 1$ & $\begin{array}{l}1: 4: 3 \\
2: 7: 3 \\
0: 1: 5 \\
0: 7: 18 \\
0: 1: 1 \\
1: 36: 34 \\
0: 1: 2 \\
0: 1: 2 \\
0: 6: 4 \\
1: 4: 3 \\
0: 8: 17 \\
3: 1: 9 \\
1: 6: 7 \\
1: 12: 9 \\
0: 4: 4 \\
1: 28: 22 \\
\\
0: 0: 1\end{array}$ & $\begin{array}{l}0: 9: 10 \\
0: 1: 0\end{array}$ & $0: 1: 0$ & $0: 2: 0$ \\
\hline
\end{tabular}




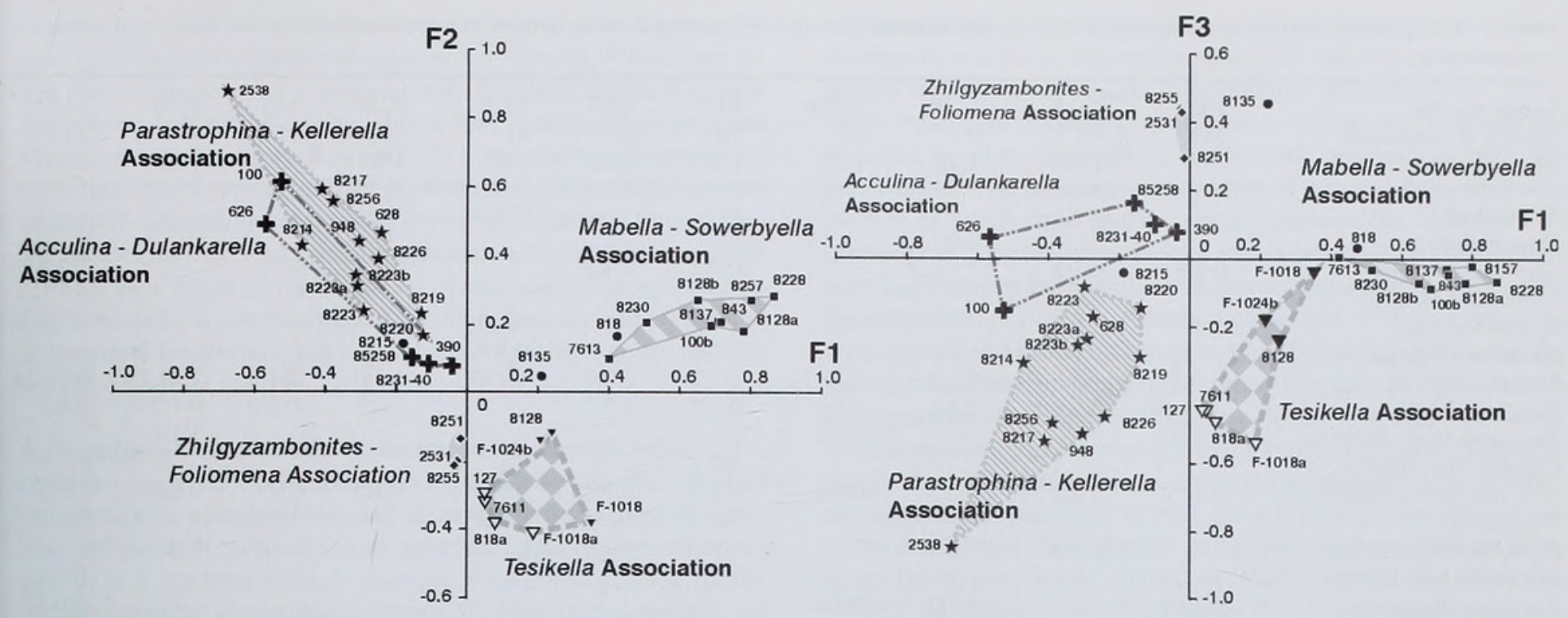

Fig. 9 Two-dimensional principal component analysis plots on first (F1), second (F2) and third (F3) eigenvectors of selected brachiopod samples from the Anderken Formation shown on Tables 1-6.

sorbulakensis formed a separate monotaxic community which inhabited a mobile sandy bottom in peritidal environments, perhaps tidal flats.

2. The Tesikella Association (average Diversity Index 1.18; observed range $0.33-2.16, \mathrm{~N}=7$ ). This is a low-diversity strophomenide-dominated brachiopod association. It is widespread in shallow marine environments of BA-2, which are mainly fine-grained sands with subhorizontal stratification, occasional storm beds with mollusc coquinas and locally abundant plant remains of Akdalaphyton caradoci. This association is defined by the index species Tesikella necopina, an endemic species and genus restricted only to the Lower Anderken Formation. This species pursued an opportunistic life strategy and expanded into environments inhabited mostly by gastropod and bivalved mollusc communities, in which rhynchonelliformean brachiopods, if they occur, are an insignificant component of the assemblage and show patchy distribution. Traces of tidal currents, ripple marks and occasional storm beds suggest rather turbulent environments occasionally affected by seasonal storms. Shells in all the samples are mostly disarticulated (Table 2) and some contamination by allochthonous shells from adjacent associations cannot be excluded. However, results of the Principal Component Analysis show that all the samples referred to the Tesikella Association form a distinct cluster and are characterised by low positive values of $\mathrm{F} 1$ and negative values of the two other maximum directions of variation (F2 and F3). Sample 1018, which may be contaminated by allochthonous shells, shows low negative values of F3 similar to the samples of the Mabella-Sowerbyella Association (Fig. 9).

In its pioneer stage, the Tesikella Association is characterised by the appearance of Tesikella necopina in mollusc-dominated environments, where it is the only brachiopod (Samples $127,7611,8127-2 b$, 8138 ), or where it comprises more than $50 \%$ of the brachiopod fauna together with Longvillia lanx, Sowerbyella rukavishnikovae (up to $34 \%$ ) and Eodalmanella extera (up to $18 \%$ ). At its mature stage the association includes four to eight species usually common in the Sowerbyella-Mabella Association, e.g. Christiania egregia (up to $35 \%$ ), Sowerbyella rukavishnikovae (up to $50 \%$ ) and Pionodema opima ( $56 \%$ in one sample). All the other taxa constitute less than $5 \%$ of individuals in any particular sample. Among other groups bivalved molluscs, the trilobites "Isotelus" romanovskyi, Lonchodomas tecturmasi and Dulanaspis levis anderkensis occur. The echinoderm fauna is dominated by the cystoidean Clivosocystis minusculus Stukalina which is known only from columnals. The abundance of coquinas and plant remains suggests biogenic fixation of a sandy substrate.

Sample 1018 from the Kotnak Mountains is placed within the field of the Tesikella Association (Fig. 9), but differs in high taxonomic diversity and the occurrence of taxa characteristic of the SowerbyellaMabella and Acculina-Dulankarella associations, e.g. Anoptambonites orientalis, Glyptomena onerosa, Limbimurina sp. and Acculina kulanketpesica. This sample came from a bed of bioclastic sandy limestone, which is an atypical lithology for the Tesikella Association, more likely to have been deposited within a bar system, and contains an allochthonous brachiopod coquina representing a mixture of several life associations. The abundance of coarse clastics and storm beds formed mostly by the bivalve Ctenodonta sp. (Samples 1017, 1019) in the Anderken Formation of this section suggest turbulent depositional environments within a shore-face zone comparable with the lower part of the Otar beds in the Dulankara Formation of the Dulankara section in the southeastern Chu-Ili Range (Popov et al. 2000).

3. Mabella-Sowerbyella Association (average Diversity Index 1.30; observed range $0.83-1.86, \mathrm{~N}=9$ ) is another low diversity association of BA-2 dominated by strophomenides. It is recognised in the Anderkenyn-Akchoku, Kopalysai and Buldukbai-Akchoku sections by the predominance of Mabella conferta and Sowerbyella rukavishnikovae which together comprise $40-80 \%$ of individuals in the assemblage. Glyptomena onerosa, Shlyginia fragilis and Anoptambonites orientalis mainly occur in this association (Table 3). As in the mature Tesikella Association, orthides are represented only by Eodalmanella extera and Pionodema opima, which do not usually co-occur. This association is confined to a fine clastic substrate of silts and fine-grained sands, usually with traces of bioturbation and locally abundant concentrations of the plant Akdalaphyton caradoci. In samples from the Anderkenyn-Akchoku section brachiopods are preserved disarticulated, but in the Kopalysai and Buldukbai-Akchoku sections the number of articulated specimens increases up to 50 percent, suggesting rapid burial and lack of significant post-mortem displacement of the shells. The most common trilobites in the associated faunal assemblage are Lonchodomas 
Table 3 Composition of Mabella-Sowerbyella Association from the Anderken Formation showing number of complete shells, ventral and dorsal valves respectively.

\begin{tabular}{|c|c|c|c|c|c|c|c|c|c|c|c|}
\hline $\begin{array}{l}\text { Sample number } \\
\text { Number of individuals } \\
\text { Diversity index }\end{array}$ & $\begin{array}{l}100 b \\
248 \\
1.09\end{array}$ & $\begin{array}{l}7613 \\
50 \\
1.79\end{array}$ & $\begin{array}{l}8128 \mathrm{a} \\
9 \\
1.82\end{array}$ & $\begin{array}{l}8128 b \\
27 \\
1.21\end{array}$ & $\begin{array}{l}8137 \\
10 \\
1.73\end{array}$ & $\begin{array}{l}8257 \\
21 \\
1.31\end{array}$ & $\begin{array}{l}8228 \\
41 \\
1.62\end{array}$ & $\begin{array}{l}8229 \\
5 \\
1.86\end{array}$ & $\begin{array}{l}110 \\
11 \\
0.83\end{array}$ & $\begin{array}{l}8230 \\
36 \\
1.13\end{array}$ & $\begin{array}{l}843 \\
75 \\
1.39\end{array}$ \\
\hline Trematis sp. & & & & & & & $0: 0: 1$ & & & & \\
\hline Paracraniops sp. & & & $0: 0: 1$ & & & & & & & & \\
\hline Glyptomena onerosa & $0: 5: 9$ & $0: 1: 2$ & & & $0: 2: 2$ & $0: 0: 2$ & & $0: 1: 0$ & & & $0: 3: 4$ \\
\hline Christiania egregia & & $0: 0: 1$ & & & & & & & & & \\
\hline Foliomena prisca & & & & & & & $0: 1: 0$ & & & & \\
\hline Dulankarella larga & & & & & & & $0: 1: 0$ & & & & \\
\hline Mabella conferta & $0: 115: 7$ & $1: 0: 0$ & $0: 1: 2$ & $0: 11: 14$ & $0: 1: 2$ & $6: 2: 0$ & $13: 10: 2$ & $1: 1: 0$ & $7: 1: 0$ & $1: 24: 13$ & $0: 15: 24$ \\
\hline Shlyginia fragilis & $0: 15: 10$ & $0: 10: 16$ & $0: 3: 1$ & $0: 2: 0$ & $0: 3: 2$ & $4: 3: 1$ & & & $0: 2: 0$ & $0: 1: 2$ & $0: 0: 1$ \\
\hline Anoptambonites orientalis & $0: 9: 20$ & & & $0: 0: 2$ & & & & & & $1: 1: 1$ & \\
\hline Olgambonites insolita & & & & & $0: 0: 1$ & & & & & & \\
\hline $\begin{array}{l}\text { Sowerbyella rukavishnikovae } \\
\text { Triplesia sp. }\end{array}$ & $0: 28: 79$ & $0: 2: 2$ & $0: 0: 2$ & $0: 4: 5$ & $0: 2: 2$ & $0: 2: 1$ & $\begin{array}{l}0: 5: 2 \\
0: 2: 3\end{array}$ & $0: 1: 0$ & & $0: 2: 2$ & \\
\hline Phragmorthis conciliata & & 1:0:0 & & & & & & & & $0: 0: 1$ & \\
\hline Plectorthis burultasica & & & & & & & & & & & $0: 1: 2$ \\
\hline Eodalmanella extera & $0: 3: 10$ & & $0: 1: 0$ & $0: 2: 4$ & & & & & & & $0: 6: 12$ \\
\hline Pionodema opima & & $1: 24: 24$ & & & & 1:1:0 & $2: 8: 5$ & $1: 1: 1$ & 0:0:1 & $0: 4: 4$ & $1: 24: 24$ \\
\hline Rhynchotrema akchokense & & $0: 2: 1$ & & & & & & & & & $2: 3: 5$ \\
\hline
\end{tabular}

Table 4 Composition of Acculina-Dulankarella and Parastrophina-Kellerella associations from the Anderken Formation showing number of complete shells, ventral and dorsal valves respectively.

\begin{tabular}{|c|c|c|c|c|c|c|c|}
\hline \multirow[b]{2}{*}{ Sample number } & \multicolumn{5}{|c|}{ Acculina-Dulankarella Association } & \multicolumn{2}{|c|}{ Parastrophina-KellerellaAssociation } \\
\hline & F-100 & F-1041a & 626 & 85258 & $8231-40$ & 628 & 8219 \\
\hline Number of individuals & 168 & 113 & 112 & 32 & 11 & 40 & 2 \\
\hline Diversity index & 5.07 & 1.91 & 4.87 & 2.60 & 1.25 & 5.42 & \\
\hline Mezotreta? sp. & $0: 1: 0$ & & & & & & \\
\hline Schizotreta sp. & & & $1: 0: 0$ & & & $0: 0: 1$ & \\
\hline Bellimurina sarytumensis & & $1: 4: 0$ & & & & $0: 0: 1$ & \\
\hline Teratelasmella chugaevae & $12: 0: 0$ & & $4: 0: 2$ & & & $0: 0: 1$ & \\
\hline Furcitellinae gen. et sp. indet. & $1: 1: 1$ & $2: 1: 2$ & $1: 0: 1$ & & & $0: 0: 1$ & \\
\hline Limbimurina? sp. & $0: 0: 1$ & & & & & $0: 1: 1$ & \\
\hline Christiania aff. sulcata & & & & & & $1: 6: 4$ & \\
\hline Christiania egregia & $1: 4: 1$ & $2: 1: 3$ & $0: 2: 0$ & $5: 1: 0$ & & & \\
\hline Craspedelia tata & $7: 2: 0$ & & $6: 4: 0$ & & $0: 1: 0$ & $1: 0: 1$ & \\
\hline Acculina kulanketpesica & $12: 1: 3$ & $32: 3: 1$ & $1: 1: 1$ & $4: 2: 1$ & $1: 5: 1$ & & \\
\hline Dulankarella larga & $25: 1: 0$ & $47: 0: 0$ & $11: 1: 0$ & & 1:1:1 & & \\
\hline Kajnaria rugosa & $2: 0: 0$ & $3: 1: 0$ & 1:0:0 & & & $2: 1: 0$ & \\
\hline Mabella conferta & $1: 0: 0$ & $3: 0: 0$ & & & & $0: 1: 0$ & \\
\hline Shlyginia fragilis & & & & $0: 1: 0$ & & $0: 1: 0$ & \\
\hline Glyptambonites sp. & $0: 2: 0$ & & & & & & \\
\hline Sortanella aff. quinquecostata & $1: 1: 2$ & & $2: 3: 2$ & & & $0: 1: 1$ & \\
\hline Anoptambonites convexus & $12: 1: 3$ & & $13: 6: 3$ & $1: 2: 1$ & 1:0:1 & & \\
\hline Sowerbyella aff. ampla & $0: 2: 3$ & & $2: 8: 0$ & $0: 1: 4$ & & & \\
\hline Gacella institata & $3: 1: 4$ & & $5: 1: 3$ & 2:0:0 & & $0: 0: 1$ & \\
\hline Placotriplesia spissa & $2: 1: 0$ & $3: 2: 1$ & $1: 1: 3$ & $1: 0: 0$ & & & \\
\hline Triplesia aff. subcarinata & & & & & & $0: 0: 2$ & \\
\hline Bicuspina rukavishnikovae & $1: 0: 0$ & & 1:0:0 & & & & \\
\hline Grammoplecia wrighti & & & $1: 0: 1$ & & & $0: 0: 2$ & \\
\hline Skenidioides sp. & & & & & & & \\
\hline Dolerorthis pristina & $1: 4: 2$ & & $0: 1: 0$ & & & $0: 2: 2$ & \\
\hline Glyptorthis sp. & & & $1: 0: 0$ & & & $0: 2: 1$ & \\
\hline Austinella sarybulakensis & & & & $3: 1: 1$ & & & \\
\hline Plectorthis burultasica & & $1: 1: 0$ & & & & $1: 0: 0$ & \\
\hline Phragmorthis conciliata & & & $0: 1: 0$ & & & & \\
\hline Parastrophina iliana & $5: 1: 1$ & $4: 0: 0$ & $7: 0: 0$ & $2: 0: 0$ & & $2: 0: 1$ & \\
\hline Parastrophina plena & $7: 0: 0$ & & & & & & 1:0:0 \\
\hline Liostrophia pravula & $3: 0: 2$ & & & & & $1: 0: 4$ & \\
\hline Plectosyntrophia? unicostata & $2: 0: 0$ & & $4: 0: 0$ & & & & \\
\hline Schizostrophina margarita & $1: 3: 0$ & & 2:0:0 & & & $1: 0: 0$ & $1: 0: 0$ \\
\hline Rhynchotrema akchokense & $2: 0: 0$ & & $1: 0: 0$ & & & $1: 0: 0$ & \\
\hline Pectenospira pectenata & & & $1: 1: 1$ & & & & \\
\hline Kellerella misiusi & $3: 0: 0$ & & $1: 0: 0$ & & & & \\
\hline Nikolaispira guttula & $2: 0: 0$ & & & & & & \\
\hline
\end{tabular}


tecturmasi, Dulanaspis levis anderkensis and Styginella macrophtalma, whereas Bronteopsis extraordinaris, Pliomerina sp. and Remopleurides sp. are relatively rare. Bivalved molluscs include Anderkenia ledomorpha, Clionichia crispa, Edmondia obliqua and Praemyophoris? antiqua (Khalfin 1958), and gastropods are represented mostly by Lophospira cribrosa Vostokova. Other fossils include unidentified fenestrate and ramose bryozoans of at least three different species, cystoid and crinoid columnals identified by Stukalina (1988) as Clivosisystis clivosus, Communicystis communis, Digiticrinus levis, Ordinacrinus punctatus, Ristnacrinus bifidus and Shizocrinus lentiformis, the cystoidean Polycosmites? sp. and the starfish Stenaster obtusus.

4. Acculina-Dulankarella Association (Diversity Index 3.14; observed range 1.25-5.07, $\mathrm{N}=5$ ) is characteristic of a nodular algal limestone with abundant dasyclad algae which was deposited in the base and flanks of carbonate build-ups in the upper Anderken Formation. It is a medium to high diversity association defined by the occurrence of the plectambonitoideans Acculina kulanketpesica and Dulankarella larga. Other brachiopods include Teratelasmella chugaevae, Kajnaria rugosa, Gacella institata and Austinella sarybulakensis which do not exceed $5 \%$ in other associations. Other components of the assemblage are taxa common in the ParastrophinaKellerella Association (Tables 4-5), whereas Christiania egregia is the only abundant species characteristic also of the MabellaSowerbyella Association. Mabella conferta and Shlyginia fragilis occur sporadically and do not exceed $5 \%$ in a particular sample. There are abundant green algae: Apidium parvulum, Cyclocrinites nikitini, Mastopora reticulata, Mastopora nana and Sinuatipora bucera and the red alga Contexta binaria (Gnilovskaya in Nikitin et al. 1974). Small organic build-ups up to $30 \mathrm{~cm}$ across of the algae Girvanella and Renalcis are also characteristic and encrust brachiopod shells and green algae. The substrate was mainly of silt and lime mud with patches of hardground and numerous bioclasts. The abundance of brachiopods preserved as conjoined valves (45-64\%) in combination with the abundant flora of algae suggests quiet environments within the euphotic zone of BA-3. Strophomenides (61-90\%) constitute the most diverse and abundant component of the brachiopod fauna. The second most abundant group is the camarelloideans (4-14\%), mostly Parastrophina iliana and relatively rare Parastrophina plena, Eoanastrophia unicostata, Liostrophia pravula and Schizotretinamargarita, which do not exceed $5 \%$ in a particular sample; and orthides, rhynchonellides and spire-bearing groups form an insignificant part of the association. Among other groups trilobites are the most abundant. These were partly studied by Weber (1948) and Chugaeva (1958), but details remain inadequate. The most characteristic taxa are: Illaenus sp., Acrolichas punctata, Cheirurus sp., Eokosovopeltis romanovskyi, Mesotaphraspis spinosus, Pliomerina sulcifrons and Sphaerexochus sp. A diverse echinoderm fauna was identified mostly from cystoid and crinoid columnals (Stukalina 1988). Among molluscs the most characteristic is the cephalopod Discoceras kazakhstanensis Barskov. The rare corals Amsassia sp. and Lichenaria sp., clathrodictyid stromatoporoids, gastropods and bivalved molluscs are also reported, but remain poorly known.

Table 5 Composition of Parastrophina-Kellerella Association from the Anderken Formation showing number of complete shells, ventral and dorsal valves respectively.

\begin{tabular}{|c|c|c|c|c|c|c|c|c|c|}
\hline $\begin{array}{l}\text { Sample number } \\
\text { Number of individuals } \\
\text { Diversity index }\end{array}$ & $\begin{array}{l}948 \\
200 \\
2.64\end{array}$ & $\begin{array}{l}2538 \\
200 \\
4.91\end{array}$ & $\begin{array}{l}8214 \\
33 \\
2.63\end{array}$ & $\begin{array}{l}8226 \\
12 \\
1.61\end{array}$ & $\begin{array}{l}8217 \\
13 \\
2.34\end{array}$ & $\begin{array}{l}8223 \\
15 \\
2.58\end{array}$ & $\begin{array}{l}8223 \mathrm{a} \\
18 \\
3.11\end{array}$ & $\begin{array}{l}8223 b \\
9 \\
2.76\end{array}$ & $\begin{array}{l}8256 \\
31 \\
2.33\end{array}$ \\
\hline Nushbiella dubia & & $0: 1: 1$ & & & & & $0: 1: 0$ & & \\
\hline Bellimurina sp. & $0: 2: 1$ & $0: 1: 0$ & $1: 2: 0$ & & & & & & $0: 1: 0$ \\
\hline Limbimurina sp. & & $0: 0: 1$ & & & & & & $0: 0: 2$ & \\
\hline Christiania aff. sulcata & & $0: 2: 1$ & $1: 4: 1$ & $0: 1: 0$ & $0: 1: 0$ & $0: 2: 0$ & $0: 1: 1$ & $0: 2: 1$ & \\
\hline Foliomena prisca & & & & & & $0: 0: 1$ & & & \\
\hline Craspedelia tata & $2: 2: 1$ & $8: 4: 3$ & $1: 2: 0$ & & & & $0: 1: 0$ & $0: 1: 0$ & \\
\hline Kajnaria rugosa & & & & & & $1: 1: 0$ & & & \\
\hline Sortanella aff. quinquecostata & $3: 2: 1$ & $4: 0: 2$ & & & & & & & \\
\hline Anoptambonites convexus & & $9: 6: 2$ & & & & $0: 3: 1$ & & & $1: 3: 4$ \\
\hline Sowerbyella aff. ampla & $2: 2: 1$ & $3: 1: 1$ & $2: 2: 2$ & & $0: 2: 0$ & & $3: 1: 0$ & $1: 0: 0$ & \\
\hline Triplesia aff. subcarinata & & $2: 0: 0$ & & & & & & & \\
\hline Placotriplesia spissa & & $3: 1: 7$ & $0: 2: 1$ & & & $1: 1: 0$ & & & $0: 0: 1$ \\
\hline Grammoplecia wrighti & & & $0: 2: 1$ & & & & & & \\
\hline Skenidioides sp. & & & $1: 0: 0$ & $0: 1: 0$ & & & & $0: 1: 0$ & \\
\hline Dolerorthis pristina & $4: 5: 7$ & $0: 1: 1$ & $2: 1: 3$ & & $0: 0: 1$ & $0: 0: 1$ & & $0: 1: 0$ & \\
\hline Glyptorthis sp. & $0: 2: 1$ & $2: 2: 1$ & $3: 1: 1$ & & & & $0: 1: 1$ & & $0: 0: 1$ \\
\hline Plectorthis burultasica & & $3: 1: 1$ & & & & & & & \\
\hline Phaceloorthis sp. & & 1:0:0 & & & & & & & \\
\hline Bowanorthis? devexa & 7:0:0 & $5: 0: 0$ & & & & & & & \\
\hline Phragmorthis conciliata & & $2: 0: 1$ & & & & & $0: 0: 1$ & & \\
\hline Parastrophina iliana & $15: 0: 0$ & $15: 0: 1$ & & & & & & & 2:0:0 \\
\hline Parastrophina plena & $62: 0: 0$ & $17: 0: 1$ & $3: 0: 0$ & $2: 1: 1$ & $2: 0: 0$ & & $1: 0: 0$ & $1: 0: 0$ & $5: 0: 0$ \\
\hline Ilistrophina tesikensis & $14: 0: 0$ & & & & & & & & \\
\hline Liostrophia pravula & $7: 0: 0$ & $13: 0: 1$ & & & & $3: 0: 0$ & & & $3: 0: 0$ \\
\hline Plectosyntrophia? unicostata & & $1: 0: 0$ & & & $0: 0: 1$ & & & & \\
\hline Schizostrophina margarita & & $16: 0: 0$ & & & $0: 0: 1$ & $0: 0: 1$ & & & $5: 3: 2$ \\
\hline Didymelasma cf. transversa & & $1: 0: 0$ & & & & & & & \\
\hline Rhynchotrema akchokense & $2: 0: 0$ & $2: 0: 0$ & & & & & & & \\
\hline Pectenospira pectenata & $14: 1: 1$ & 3:0:0 & $1: 0: 0$ & & & & $3: 0: 0$ & & \\
\hline Kellerella misiusi & $15: 0: 1$ & $39: 0: 0$ & & $2: 0: 0$ & $5: 0: 0$ & & $2: 0: 0$ & & $5: 0: 0$ \\
\hline Nikolaispira guttula & $13: 0: 0$ & 20:0:0 & & $1: 0: 0$ & & & $2: 0: 0$ & & \\
\hline Acculina sp. & & $0: 1: 1$ & & & & & & & \\
\hline
\end{tabular}


5. Parastrophina-Kellerella Association (Diversity Index 3.17, observed range $1.61-5.42, \mathrm{~N}=10$ ) is closely associated with carbonate build-ups and also belongs to BA-3. These build-ups were interpreted by Nikitin et al. (1974) as a chain of bioherms with a frame built by the cyanobacterians Girvanella and Renalcis: however, micritic limestone usually comprises the most significant part of the volume of the rock in the core of a build-up. According to Nikitin et al. (1974), these build-ups form a low ridge, raised about 1.5-3 $\mathrm{m}$ above surrounding areas with fine clastic sedimentation. Fossils are usually concentrated in pockets of bioclastic limestone between individual bioherms and mounds (Samples 948, 2538, 8223a, 8256). Composition of this association is essentially similar to the Acculina-Dulankarella Association, with more than $80 \%$ of recorded species in common. However, the abundance of camarelloideans increases up to $49 \%$ (Sample 948) and the archaic spire-bearing brachiopods Pectenospira pectenata, Kellerella misiusi and Nikolaispira guttula constitute a significant part of the association $(21-42 \%$ in the most representative samples), whereas in the Acculina-Dulankarella Association they are less than $2 \%$ (Table 5). The relative abundance of strophomenides decreases significantly and such genera as Acculina, Dulankarella, Mabella and Shlyginia disappear completely. Christiania is represented by the species $C$. aff. sulcata, which is closely linked to this association. Diminution in the sizes of the strophomenides might reflect the predominance of hard grounds. Taxonomic composition of the association is modified in the bedded bioclastic limestone which has large ooids (up to $1 \mathrm{~cm}$ across) on the top and flanks of the core (Samples 8214, 8217, 8223, 8223 b). Brachiopods are relatively rare and dispersed through the rock. Relative abundance of strophomenides, and especially Christiania aff. sulcata, increases, whereas spire-bearing brachiopods become rare or completely disappear in some samples $(8214,8223$, 9223b). According to the Principal Component Analysis these occupy an intermediate position between the cluster formed by samples of the Acculina-Dulankarella Association and samples 948, 2538, 8256, which represent the fully developed Parastrophina-Kellerella Association (Fig. 8B).

The associated trilobite fauna is only partly known and includes such taxa as Illaenus sp., Acrolichas punctata, Amphilichas punctata, Eokosovopeltis romanovskyi, Glaphurina weberi, Mesotaphraspis spinosus, Pliomerina sulcifrons, Selenoharpes sp. and Sphaerexochus aff. hisingeri (Weber 1948, Chugaeva 1958, Kolobova \& Popov, 1986). Crinoid columnals usually represent the most important source of bioclasts in the rock. They mostly belong to Webericrinus variabilis, Ordinacrinus ordinaris, Malovicrinus depressus, Tatjanicrinus crusciformis, Flexicrinus flexus, Communicrinus communis and Multifidocrinus mulrifidus (Stukalina 1988).

In the eastern part of the Anderkenen-Akchoku section (Sample 8226), isolated carbonate build-ups up to $16 \mathrm{~m}$ thick appear within Unit 2, which is mostly cross-bedded sandstone containing lingulide and mollusc associations. It is likely that these build-ups formed almost intertidally, but, except for a much lower diversity, the brachiopod assemblage retains a relative abundance of spire-bearers (Kellerella misiusi) and camerelloideans (Parastrophina plena) typical of the Parastrophina-Kellerella Association, whereas trilobites such as Acrolichas sp., Eokosovopeltis romanovskyi, Sphaerexochus aff. hisingeri and Illaenus sp. also show close similarity to the assemblage from the carbonate unit in the upper part of the Anderken Formation.

6. Zhilgyzambonites-Foliomena Association (Diversity Index 1.21; observed range $1.14-130, \mathrm{~N}=3$ ) is known from three samples collected from the unit of mudstones and siltstones in the uppermost
Table 6 Composition of Zhilgyzambonites-Foliomena Association from the Anderken Formation showing number of complete shells, ventral and dorsal valves respectively.

\begin{tabular}{llll}
\hline Sample number & 2531 & 8251 & 8255 \\
Number of specimens & 4 & 4 & 15 \\
Diversity index & 1.44 & 0.72 & 1.48 \\
\hline Foliomena prisca & $1: 0: 0$ & $0: 1: 0$ & $1: 3: 3$ \\
Olgambonites insolita & & & $0: 3: 2$ \\
Zhilgyzambonites extenuata & $0: 2: 1$ & $0: 3: 3$ & $2: 5: 5$ \\
Kassinella? sp. & & & $0: 0: 1$ \\
Chonetoidea sp. & & & $1: 0: 0$ \\
Anisopleurella sp. & $0: 1: 1$ & & \\
\hline
\end{tabular}

Anderken Formation in the Anderkenyn-Akchoku section (Figs 3, 5, Unit 6, Table 6). Brachiopods are a minor part of a trilobite-dominated benthic assemblage, which includes Amphitrion cf. radians, Ampixinella sp., Birmanites almatiensis, Bronteopsis extraordinaris, Cheraurus kassini, Cybele weberi, Dionide kazachstanica, Dindymene sp., Hammatocnemis sp., Microparia speciosa, Ovalocephalus sp., Granulatagnostus granulatus and Sphaerognostus sp. (Chugaeva 1958, Nikitin et al. 1974). Co-occurrence of agnostids, cyclopygids and Ovalocephalus allows us to refer this assemblage to the Ovalocephalus fauna of Fortey (1997) which is characteristic of outer shelf trilobite biofacies corresponding to BA 4-5. Cooccurrence of the Foliomena and the Ovalocephalus faunas is common in late Caradoc to early Ashgill deep water benthic communities in South China (Rong et al. 1994). The Zhilgyzambonites-Foliomena Association includes only six strophomenide genera. Two of them (Olgambonites and Zhilgyzambonites) are Kazakhstan endemics, whereas Anisopleurella and Kassinella are characteristic of early Foliomena faunas in the Caradoc of China (Rong et al. 1999) and elsewhere.

\section{OVERALL PALAEOECOLOGY}

The sequence of brachiopod associations in the Anderken Formation shows an onshore-offshore pattern with a monotaxic lingulide community inhabiting mobile sand nearshore, low diversity mollusc and brachiopod associations of BA-2 on a shallow clastic shelf, medium to high diversity faunas of BA-3 linked with carbonate build-ups, and a deep water Foliomena fauna as part of a trilobite-dominated benthic assemblage in BA 4-5. In terms of abundance, diversity and taxonomic composition, the five associations formed by rhynchonelliformean brachiopods can be subdivided into three groups, which show little interaction and apparently evolved independently. They are: 1, low-diversity strophomenide-dominated Tesikella and Mabella-Sowerbyella Associations of shallow clastic shelf corresponding to BA-2; , medium to high diversity AcculinaDulankarella and Parastrophina-Kellerella Associations closely linked to carbonate build-ups; and 3, a deeper-shelf Zhilgyzambonites-Foliomena Association representing an early Foliomena Fauna.

The predominance of strophomenides in environments corresponding to BA-2, which is usually dominated by rhynchonellides and spire-bearing taxa in the late Ordovician and Silurian (Boucot 1975; Ziegler et al. 1968), is a distinctive feature of the Anderken sequence of communities. The Tesikella and Mabella-Sowerbyella Associations share eight brachiopod species but Tesikella necopina (the index species of the former association) does not usually cooccur with Mabella conferta and Shlyginia fragilis. The Tesikella necopina Association also demonstrates significant variations in 
Table 7 Additional list of brachiopod taxa from localities in the Anderken Formation not referred to a particular association

\begin{tabular}{|c|c|c|c|c|c|c|c|}
\hline $\begin{array}{l}\text { Sample number } \\
\text { Number of specimens }\end{array}$ & $\begin{array}{l}42 \\
3\end{array}$ & $\begin{array}{l}818 \\
4\end{array}$ & $\begin{array}{l}1628 \\
4\end{array}$ & $\begin{array}{l}8215 \\
10\end{array}$ & $\begin{array}{l}620 \\
13\end{array}$ & $\begin{array}{l}8251 \mathrm{a} \\
2\end{array}$ & $\begin{array}{l}8135 \\
2\end{array}$ \\
\hline $\begin{array}{l}\text { Glyptomena onerosa } \\
\text { Christiania aff. sulcata } \\
\text { Craspedelia tata } \\
\text { Dulankarella larga } \\
\text { Mabella conferta } \\
\text { Shlyginia fragilis } \\
\text { Anaptambonites orientalis } \\
\text { Sowerbyella? aff. ampla } \\
\text { Sowerbyella rukavishnikovae } \\
\text { Triplesia } \text { aff. subcarinata } \\
\text { Placotriplesia spissa } \\
\text { Grammoplecia wrighti } \\
\text { Plectorthis burultasica } \\
\text { Eodalmanella extera } \\
\text { Dolerorthis pristina } \\
\text { Pionodema opima }\end{array}$ & $0: 1: 0$ & $\begin{array}{l}\text { 1:0:0 } \\
0: 0: 1\end{array}$ & $1: 3: 0$ & $\begin{array}{l}1: 4: 1 \\
0: 1: 0\end{array}$ & $\begin{array}{l}2: 1: 8 \\
1: 0: 1 \\
2: 0: 1\end{array}$ & 2:0:0 & $0: 1: 0$ \\
\hline
\end{tabular}

relative abundance and taxonomic composition from one sample to another, which may reflect its opportunistic character and higher environmental stress, whereas the Mabella-Sowerbyella Association, in spite of its low diversity ( 4 to 8 genera per sample), shows a relatively constant taxonomic composition in most samples (Table 3 ), and this association forms a compact cluster in the Principal Components Analysis (Fig. 9). Comparison with somewhat younger Ctenodonta-Sowerbyella, Altaethyrella-Nalivkinia (Pronalivkinia) and Dinorthis Associations of the lower Dulankara Formation which inhabited similar environments on the shallow clastic shelf on the Chu-Ili Plate in the late Caradoc-early Ashgill (Popov et al. 2000), suggest a rapid faunal turnover. In these younger faunas Sowerbyella and Shlyginia retained their dominant position and Anoptambonites also remained a characteristic minor component, but most of the Anderken genera disappeared (e.g. Tesikella, Eodalmanella and Pionodema) or moved into the middle shelf (Mabella and Glyptomena) and were replaced by rhynchonellides such as Altaethyrella and atrypides such as Nalivkinia (Pronalivkinia). In contrast, the orthides (e.g. Plaesiomys, Bokotorthis and Dinorthis) became increasingly abundant.

The diverse Acculina-Dulankarella and Parastrophina-Kellerella Associations, which were closely linked with carbonate build-ups, have little in common with the faunas which inhabited shallow clastic shelves nearby. In the Acculina-Dulankarella Association strophomenides remain the most abundant brachiopods but they are mostly different genera, such as Bellimurina, Teretelasmella, Craspedelia, Acculina, Dulankarella, Kajnaria and Sortanella. Anoptambonites occurs in both associations, but as different species. Mabella and Shlyginia are mostly confined to the MabellaSowerbyella Association, as well as occurring in a few samples of the Acculina-Dulankarella Association, but as less than $5 \%$ of the sample (Table 4). They disappear in the Parastrophina-Kellerella Association (Table 5), which is possibly the earliest known brachiopod assemblage in which pentamerides together with spirebearing taxa come to a dominant position. In contrast to the brachiopod fauna of the shallow clastic shelf, assemblages associated with carbonate build-ups did not undergo any significant taxonomic change during the Caradoc. The late Caradoc to early Ashgill brachiopod fauna of the Dulankara carbonate mud-mound in the north Betpak-Dala Desert (Nikitin et al. 1996), which was also on the same Chu-Ili Plate, retained a close similarity to the Anderken fauna and contained 14 genera in common including Parastrophina and the early athyridides Kellerella and Nikolaispira. The strophomenide component was largely unchanged and such genera as Bellimurina, Limbimurina, Christiania, Craspedelia, Sortanella and Anoptambonites are common to both faunas.

The significance of the Foliomena fauna was discussed by Cocks \& Rong (1988) and Rong et al. (1994, 1999). In the Lower to Middle Caradoc it was confined mostly to South China and only in the Ashgill did it become cosmopolitan. In Kazakhstan there are no previous reports of the occurrence of Foliomena, but the associated Ovalocephalus trilobite fauna occurs in many outer shelf environments from the Middle Caradoc (Apollonov 1975; Nikitin et al. 1974). In the Anderken Formation Foliomena itself is not restricted to BA 4-5, but occurs occasionally in the Parastrophina-Kellerella (Sample 8223) and Mabella-Sowerbyella (Sample 8228) Associations. However, the other taxa, which include the two new genera and species Olgambonites insolita and Zhilgyzambonites extenuata together with rare Anisopleurella, Chonetoidea and Kassinella, are not present in shallow shelf associations. In addition. there are seven localities (Table 7) whose brachiopods cannot be referred with confidence to any of the six named associations.

Although comprehensive comparisons of the Anderken faunas with other contemporary brachiopods from elsewhere are beyond the scope of this paper, it is worth noting here that the total Anderken assemblage has much in common with that described from northwest China (Fu 1982).

\section{SYSTEMATIC PALAEONTOLOGY}

Figured and cited specimens are housed in the Natural History Museum, London (BB and BC collection numbers), Institute of Geological Sciences, Almaty, Kazakhstan (IGNA collection numbers), and in the CNIGR Museum, St. Petersburg, Russia (CNIGR collection numbers). All the quoted sample numbers are from the Anderken Formation except where stated. Bibliographical references to families and above are omitted if they are in the Treatise on Invertebrate Paleontology (Kaesler 2000).

Abbreviations given in tables of measurements and in the text are: Lv, Ld - sagittal ventral and dorsal valve length; W - maximum width; T - maximum thickness; $\mathrm{Ml}, \mathrm{Mw}$ - length and width of the muscle field; $\mathrm{Sw}, \mathrm{St}$ - width and height of tongue in the ventral valve; $\mathrm{BB} 1, \mathrm{BBw}$ length and distance between outer margins of brachiophores or socket ridges; $\mathrm{Sl}$ - length of median ridge; LPl, 
LPw length and width of lophophore platform; X - mean; S standard deviation from the mean; $r$ - coefficient of correlation; OR - observed range; max. - maximum value; min. - minimum value; $\mathrm{N}$ - number of measured or counted specimens.

Order LINGULIDA Waagen, 1885 Superfamily LINGULOIDEA Menke, 1828 Family OBOLIDAE King, 1846 Subfamily GLOSSELLINAE Cooper, 1956 Genus ECTENOGLOSSA Sinclair, 1945

TYPE SPECIES. Lingula lesueueri Rouault, 1850, from the Arenig of Normandy, France.

\section{Ectenoglossa sorbulakensis Popov, $1980 \quad$ Pl. 1, figs 1-4 \\ 1980 Ectenoglossa sorbulakensis Popov: 142, pl. 1, figs 1-4. 1984 Ectenoglossa sorbulakensis Popov; Nikitin \& Popov in Klenina et al.: 142, pl. 1, figs 1-4.}

HOLOTYPE. CNIGR 1/11523, ventral internal mould, from the Anderken Formation, locality 1024, east side of Karatal valley.

MATERIAL. Six pairs of conjoined valves, 26 ventral and 31 dorsal valves from Sample 8130a, Anderkenyn-Akchoku; Samples 822710, 8227-40 (BC 57370-73), 8227-80, Buldukbai Akchoku; 8228a, east side of Kopalysai; all Chu-Ili Range; Sample 1024, east side of Karatal Valley, south Betpak-Dala.

DESCRIPTION. Shell equivalved, elongate, subrectangular in outline, about $190 \%$ as long as wide with maximum width at mid-length, ornamented by fine concentric fila about $13-15$ per mm. Ventral valve very gently convex with narrow, triangular pseudointerarea, mainly occupied by deep pedicle groove and small propareas crossed by flexure lines. Dorsal valve gently convex, lacking pseudointerarea. Ventral interior with pair of slightly diverging, elongate, suboval umbonal muscle scars flanked laterally by pair of short diverging ridges; pedicle nerve impression well defined. Dorsal interior with weak median ridge.

DISCUSSION. Ectenoglossa sorbulakensis closely resembles Ectenoglossa minor Zhan \& Cocks (1998: 14) from the Lower Ashgill of South China in having a strongly elongate equivalved shell with subparallel lateral margins, rudimentary ventral pseudointerarea and propareas with well defined flexure lines. However, the interiors of both valves are weakly impressed in the Chinese species, which makes precise comparison difficult. The main difference of the Kazakh species from the latter is the less elongate shell outline, which is no more than twice as long as wide. A detailed description, discussion and the basic statistics of this species was provided by Popov (1980).

\section{Superfamily DISCINOIDEA Gray, 1840 \\ Family TREMATIDAE Schuchert, 1893 \\ Genus TREMATIS Sharpe, 1848}

TYPE SPECIES. Orbicula terminalis Emmons, from the Trenton Group (Caradoc), New York, U.S.A.

\section{Trematis? sp}

Pl. 1, figs 5, 6

MATERIAL. Figured dorsal valve, BC 57375 ( $\mathrm{L}=14.8, \mathrm{~W}=14.4$ ) and another dorsal valve, Samples 127, 8228, Kopalysai.

DESCRIPTION. Shell subcircular, ornamented by radial capillae of about 5 per $1 \mathrm{~mm}$ enlarged in number by intercalation and with radially arranged rounded or transversely suboval pits in the interspaces between capillae. Ventral valve unknown. Dorsal valve gently and unevenly convex in transverse profile with maximum height about one-third of the valve length from the marginal umbo. Dorsal interior unknown.

Discussion. These specimens are similar to the shells described by Cooper (1956: 275) as Trematis sp. 3 from the Cyrtonotella Zone of the Edinburg Formation (Caradoc) of Virginia in their pits and radial ornament. The ventral valve in both unnamed species remains unknown, and therefore the generic attribution is provisional.

\section{Family DISCINIDAE Gray, 1840 Subfamily ORBICULOIDEINAE Schuchert, 1929 Genus SCHIZOTRETA Kutorga, 1848}

TYPE SPECIES. Orbicula elliptica Kutorga, presumably Volkhov or Kunda Stage (Upper Arenig-Lower Llanvirn), vicinity of St. Petersburg, Russia.

\section{Schizotreta sp.}

Pl. 1, figs 7-10

MATERIAL. One pair of conjoined valves, one ventral and two dorsal valves from Samples 100 (BC 57590) and 626, AnderkenynAkchoku section; Samples 628(BC 56825), 2538, Kujandysai section

\section{PLATE 1}

Figs 1-4 Ectenoglossa sorbulakensis Popov. Sample 8227-40, Buldukbai-Akchoku section, west side of Kopalysai. 1, BC 57370, ventral exterior, $\times 2.2$, BC 57372, dorsal internal mould, $\times 2$. 3, BC 57371, dorsal exterior, $\times 2.4$, BC57373, ventral internal mould, $\times 2$.

Figs 5, 6 Trematis? sp. Sample 8228, east side of Kopalysai, BC 57375, dorsal exterior and surface ornament, $\times 6, \times 2$.

Figs 7-10 Schizotreta sp. Sample 100, Anderkenyn-Akchoku section, BC 57590, conjoined valves, posterior, dorsal, lateral and ventral views, $\times 2$.

Fig. 11, 12 Mesotreta? sp. Sample 100, Akchoku Mountain, Anderkenyn-Akchoku section, CNIGR 1/12361, ventral exterior and lateral view, $\times 8$.

Figs 13, 14 Nushbiella dubia Popov. Sample 2538, Akchoku Mountain, Kujandysai section, BC 57591; 13, dorsal exterior, $\times 8$; 14, ventral exterior, $\times 8$.

Fig. 15 Paracraniops sp. Sample 8128a, Anderkenyn-Akchoku section, BC 57377, dorsal internal mould, $\times 5$.

Figs 16-21 Longvillia lanx (Popov), Sample 1018, area 7 km southwest of Karpkuduk well, Kotnak mountains, south Betpak-Dala. 16, 17, CNIGR 27/ 11989, latex cast of cardinalia and dorsal interior, $\times 5, \times 2.18-20$, CNIGR 27/11989, dorsal, ventral and lateral views of conjoined valves, $\times 1$. 21,

CNIGR 30/11989, holotype, ventral internal mould, $\times 2$.

Figs 22-28 Bellimurina (Bellimurina) sarytumensis sp. nov. 22, 23, Sample 8214, BC 57379, holotype, Anderkenyn-Akchoku section, ventral exterior and lateral view, $\times 2$. 24, 25, Sample 2538, Akchoku Mountain, Kujandysai section, BC 57378, conjoined valves, dorsal and ventral views, $\times 3.26$, Sample 1041a, Burultas Valley, BC 57364, dorsal internal mould, × 2. 27, Sample 100, Anderkenyn-Akchoku section, BC 57380, ventral exterior, $\times 3.28$, Sample 2538, CNIGR 10/12361, dorsal external mould, $\times 3$

Fig. 29 Dolerorthis expressa Popov. Sample 1018, 7 km southwest of Karpkuduk well, Kotnak Mountains, BC 57368, ventral internal mould, $\times 1.5$.

Figs 30, 31 Furcitellinae gen. et sp. indet. Sample 628, west side of Kujandysai, BC 57381, ventral and dorsal views of conjoined valves, $\times 1.5$. 

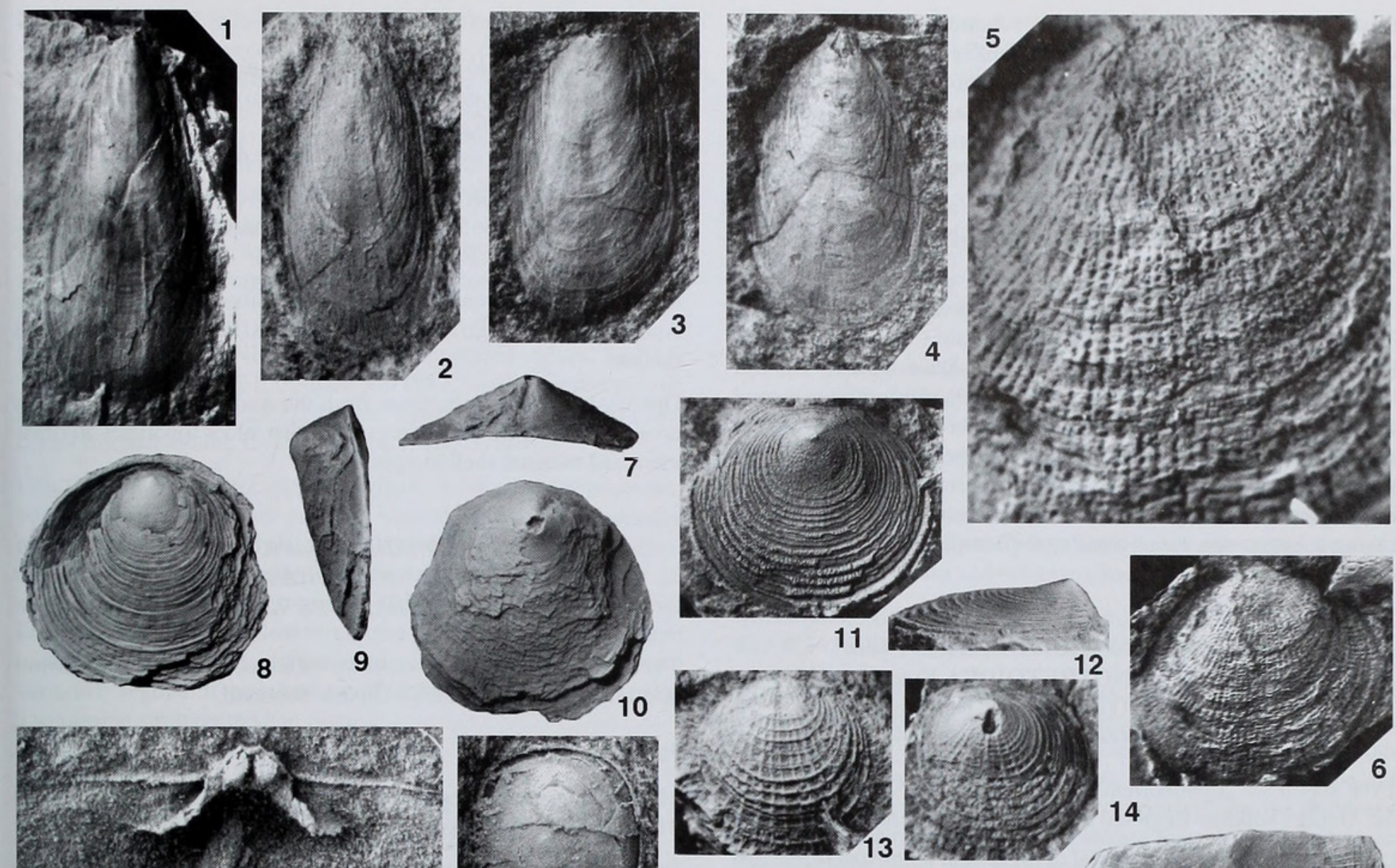

14
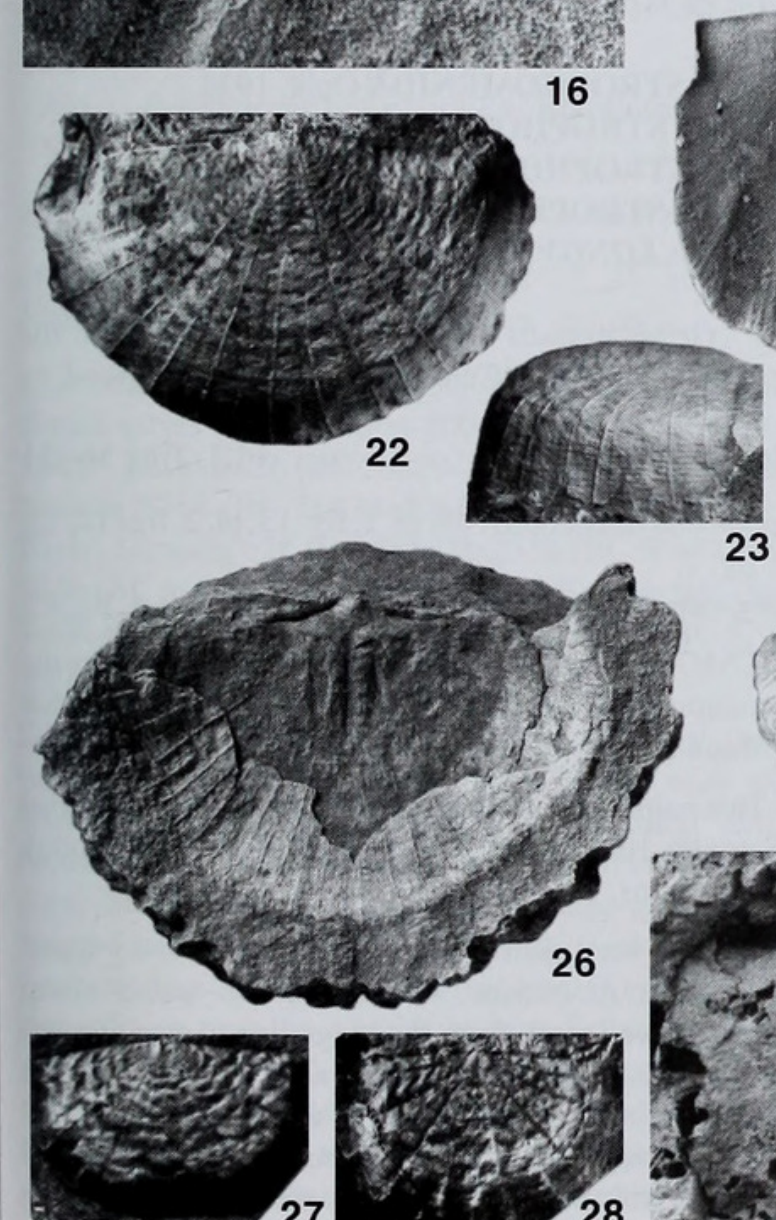

4

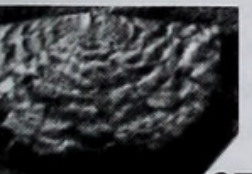

27
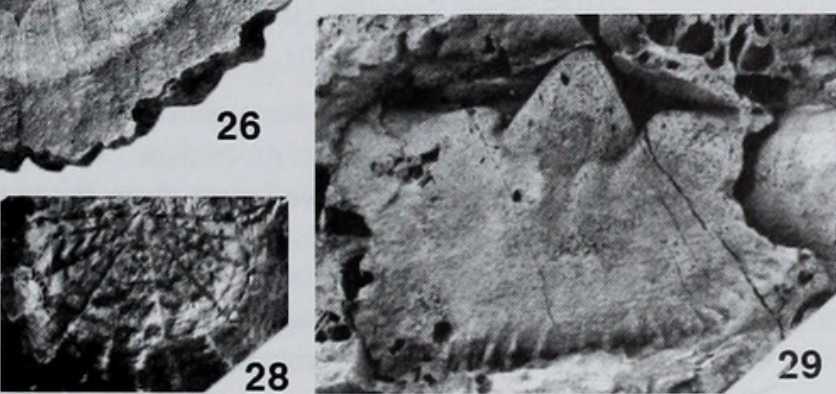
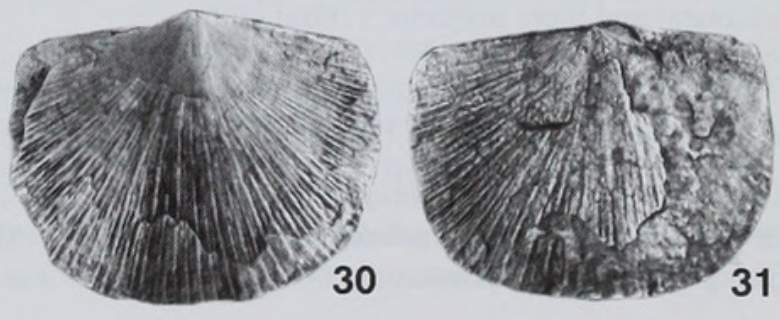
DESCRIPTION. Shell planoconvex, subcircular, ornamented by strong rounded irregular concentric rugellae of $10-11$ per $3 \mathrm{~mm}$. Ventral valve low, subconical with maximum height at the umbo which is situated about $10 \%$ of the valve length from the posterior margin. Pedicle foramen small, rounded, located at the end of narrow pedicle track covered by listrium. Dorsal valve flat with submarginal umbo. Interior of both valves not observed.

MEASUREMENTS. BC 57590, conjoined valves, $\mathrm{L}=14.8, \mathrm{~W}=14.4$, $\mathrm{T}=4.8$.

Discussion. These specimens resemble Schizotreta triangularis Popov (Nikitin et al. 1996: 85) from the late Caradoc Dulankara Regional Stage of the northern Betpak-Dala Desert, Central Kazakhstan, but differ in their subcircular valve outline, ventral umbo situated close to the posterior margin and strong, irregular concentric rugellae. In concentric ornament they somewhat resemble Schizotreta corrugata Cooper (1956: 277) from the Llandeilo Pratt Ferry Formation of Alabama, USA, but can be distinguished in having a larger size, more circular shell outline and more densely spaced concentric rugellae.

\section{Order SIPHONOTRETIDA Kuhn, 1949 Superfamily SIPHONOTRETOIDEA Kutorga, 1848 Family SIPHONOTRETIDAE Kutorga, 1848 \\ Genus MESOTRETA Kutorga, 1848}

TYPE SPECIES. Siphonotreta tentorium Kutorga, 1848: 270, from the Arenig (Volkhov Regional Stage), north-western Russia.

Discussion. The type material of Mesotreta tentorium is lost and its taxonomic position within the Siphonotretoidea is unclear. At present, our knowledge of the type species of this genus is based on a single incomplete ventral valve from the Upper Volkhov Stage (Holmer \& Popov 2000: Fig. 79,2). Mesotreta is unique among the Siphonotretida because of its low conical ventral valve with small, slightly eccentric pedicle foramen, but it possesses the hollow spines characteristic of this order. The ventral interior and dorsal valve of Mesotreta remain unknown.

\section{Mesotreta? sp. \\ Pl. 1, figs 11,12}

1986 Nushbiella dubia (Popov); Kolobova \& Popov: pl. 1, fig. 1, non fig. 2.

MATERIAL. One ventral valve (CNIGR 1/12361) from Sample 100, Anderkenyn-Akchoku section.

DESCRIPTION. Valve slightly transverse, elliptical in outline; low, subconical with eccentric umbo at $20 \%$ of valve length from the posterior margin. Foramen small, slightly elongate, suboval. Concentric ornament of up to 16 thin, evenly spaced, crowded growth lamellae and numerous fine hollow spines. Ventral interior and dorsal valve unknown.

DisCUSSION. This unnamed species resembles Siphonotreta tentorium in having a low conical ventral valve lacking a well-defined pseudointerarea and small umbonal pedicle foramen, but the Kazakhstanian specimen differs in its strongly developed lamellose ornament and more posterior ventral umbo.

Genus NUSHBIELLA Popov in Kolobova \& Popov, 1986

TYPE SPECIES. Multispinula? dubia Popov, 1977; from the Bestamak Formation, Tselinograd Regional Stage (Llandeilo), Chingiz Range, Kazakhstan.
Nushbiella dubia (Popov, 1977)

Pl. 1, figs 13,14

1977 Multispinula? dubia Popov: 104, pl. 25, figs 8-11.

1986 Nushbiella dubia (Popov) Kolobova \& Popov: 251, pl. 1, fig. 2, non fig. 1 .

2000 Nushbiella dubia (Popov) Holmer \& Popov: fig. 79, 6a, b.

HolOTYPE. CNIGR 1/10847, ventral valve, Bestamak Formation (Llandeilo), locality 553a, east side of Chagan River near KonurAulie cave, Chingiz Range, Kazakhstan.

MATERIAL. One ventral and one dorsal valve from Sample 8223a, Anderkenyn-Akchoku section; Sample 2538 (BC 57591), Kujandysai section.

Discussion. The specimens from the Anderken Formation have no significant differences from the rather older topotypes in ornament and external shell morphology.

Order CRANIOPSIDA Gorjansky \& Popov, 1985

Superfamily CRANIOPSOIDEA Williams, 1963 Genus PARACRANIOPS Williams, 1963

TYPE SPECIES. Craniops pararia Williams, 1962, from the Lower Ardmillan Series (Caradoc), Girvan, Scotland.

\section{Paracraniops sp.}

Pl. 1, fig. 15

MATERIAL. One dorsal internal mould, BC 57377, from Sample 8128a, Anderkenyn-Akchoku section.

DisCUSSION. A single specimen represents the earliest record of craniopsides from Kazakhstan. There is little doubt of the generic attribution, but there is insufficient material to allow detailed comparison with other named species of the genus.

\section{Order STROPHOMENIDA Öpik, 1934 Superfamily STROPHOMENOIDEA King, 1846 Family STROPHOMENIDAE King, 1846 Subfamily STROPHOMENINAE King, 1846 Genus LONGVILLIA Bancroft, 1933}

TYPE SPECIES. Orthis grandis J.de C. Sowerby, 1839, from the Cheney Longville Flags (Lower Caradoc), Shropshire, England.

Longvillia lanx (Popov, 1985)

Pl.1, figs 16-21

1985 Strophomena lanx Popov: 58; pl. 1, fig. 13; pl. 2, figs 12, 13; pl. 3, fig. 1 .

1985 Strophomena digna Popov: 67 nomen erratum. pl. 1, fig. 13.

HOLOTYPE. CNIGR 30/11989, ventral internal mould, from the Anderken Formation, Sample 1018a, 7 km south-west of Karpkuduk well, Kotnak Mountains, refigured here (Pl. 1, fig. 21).

MATERIAL. Two pairs of conjoined valves, 11 ventral and 8 dorsal valves from Samples 1018, 1018a, 7 km south-west of Karpkuduk well, Kotnak Mountains.

DESCRIPTION. Shell very gently convexiconcave, slightly transverse, subrectangular in outline with maximum width about one-quarter of the valve length from the hinge line. Anterior commissure rectimarginate. Ventral valve gently and evenly concave in profile with a slightly raised, pointed umbo and steeply apsacline ventral interarea bearing large, convex pseudodeltidium. Dorsal valve evenly convex with flattened umbonal area. Radial ornament 
unequally parvicostellate in posterior half of mature valves with 2 4 parvicostellae between accentuated ribs, becoming near equally parvicostellate anteriorly with 5-8 ribs along the anterior margin. Ventral interior with strong teeth and low, diverging dental plates continuing anteriorly as straight muscle bounding ridges bordering posteriorly the open subtriangular muscle field which is about $30 \%$ as long as the valve. Adductor scars narrow, weakly impressed, flanked laterally by slightly longer diductor scars. Dorsal interior with cardinal process, low, widely diverging, oblique socket ridges and a short median ridge up to $40 \%$ valve length. Adductor field weakly impressed.

MEASUREMENTS. CNIGR 29/11989, conjoined valves, $\mathrm{L}=22.5$, $\mathrm{W}=26.4, \mathrm{Iw}=23.6, \mathrm{~T}=5.1$; CNIGR 30/11989, ventral internal mould, holotype, $\mathrm{L}=26.8, \mathrm{~W}=28.3, \mathrm{Ml}=8.8, \mathrm{Mw}=9.6$; CNIGR 35/11989, dorsal internal mould, $\mathrm{L}=16.7, \mathrm{~W}=18.5, \mathrm{~T}=3.5, \mathrm{Sl}=7.8$.

Discussion. This species was originally referred to Strophomena, but it is characterised by an open ventral muscle field bounded posterolaterally by dental plates and short, diverging bounding ridges, a short dorsal median ridge and the absence of side septa, all suggesting attribution to Longvillia. It differs from the type species Longvillia grandis in its less transverse outline, with the maximum width slightly anterior to the hinge line, the radial ornament becoming nearly regular in the anterior half of the shell, and in possessing a somewhat stronger median ridge.

Subfamily FURCITELLINAE Williams, 1965 Genus BELLIMURINA (BELLIMURINA) Cooper, 1956

TYPE SPECIES. Leptaena charlottae Winchell \& Schuchert, from the Caradoc of Minnesota, U.S.A.

Bellimurina (Bellimurina) sarytumensis sp.nov. Pl. 1, figs. $22-28$.

1986 Bellimurina rudis [sic] Lu; Kolobova \& Popov: pl. 1, fig. 10.

ETymology. After Sarytuma Well in the Betpak-Dala Desert.

HOLOTYPE. BC 57379, Pl. 1, figs 22, 23, a ventral valve from Sample 8214 , Anderkenyn-Akchoku section.

MATERIAL. Two pairs of conjoined valves, ten ventral and four dorsal valves from Samples 100 (BC 56826, BC 57380), 620 (BC 56827-28) and 626 (BC 56829-31), Anderkenyn-Akchoku section; Sample 8214 (BC 56839-40, BC 57379), west side of Ashchisu River; Samples 628 (BC 56837), 2538 (BC 56838, BC 57378) and 8256 (BC 56841), Kujandysai section; Sample 948 (BC 56832-36), Tesik River; Samples 390 (BC 57365), 1041a (BC 57364), Burultas Valley.

DESCRIPTION. Shell concavoconvex, slightly transverse, subrectangular in outline, about $70 \%$ as long as wide with maximum width at mid-length with rounded cardinal extremities and rectimarginate anterior commissure. Ventral valve convex with maximum height at geniculation (about three-quarters valve length). Ventral interarea apsacline with well developed pseudodeltidium perforated apically by a minute foramen. Dorsal valve flattened with geniculation near the anterior margin. Dorsal interarea low, linear, anacline with a well-developed chilidium. Radial ornament unequally parvicostellate with 6-7 accentuated ribs originating at the umbo and up to 7 strong ribs in interspaces. About 4-7 fine parvicostellae per mm along the anterior margin. Concentric ornament
Table 8 Measurements of ventral valves of Beillimurina sarytumensis sp. nov from samples 100, 626 and 8214 from Anderkenyn-Akchoku section, Sample 2538 from Kujandysai section and Sample F-1041a from Burultas valley.

\begin{tabular}{llcc}
\hline & Lv & W & L/W \\
\hline N & 6 & 6 & 6 \\
X & 7.8 & 11.1 & $69.4 \%$ \\
S & 3.62 & 4.35 & 6.8 \\
MIN & 5.2 & 8 & $56.5 \%$ \\
MAX & 14.8 & 19.5 & $75.9 \%$ \\
\hline
\end{tabular}

of fine, slightly uneven rugellae about 2 per mm, covering all the posterior half of the shell.

Ventral interior with small teeth supported by low, divergent dental plates and small, weakly impressed subtriangular muscle field. Dorsal interior with bilobed cardinal process, widely flaring socket plates, poorly impressed median septum extending about one-third valve length, poorly impressed pair of side septa subparallel to the median septum and not extending beyond it.

MEASUREMENTS. (435/12375) conjoined valves, $\mathrm{L}=6.4, \mathrm{~W}=8.3$, $\mathrm{T}=3.0 ;(436 / 12375)$ ventral valve, $\mathrm{L}=15.4, \mathrm{~W}=21.3, \mathrm{~T}=5.4$.

DISCUSSION. These shells are most similar to, and possibly conspecific with, the specimens described by Nikitin \& Popov (1996: 16, figs 6J-N) as Bellimurina? sp. from the Dulankara Regional Stage of north Betpak-Dala in general shell shape and radial ornament with 6-7 accentuated primary ribs, but the dorsal interior in specimens from the Dulankara Stage remains unknown. The Kazakh shells are similar to the specimens described as Kiaeromena longxianensis Fu, 1982 from the Pinling Formation of northwest China in size, ornament and weakly geniculated lateral profile, but further comparison is difficult because of poor description and insufficient illustrations of that species, although it is unlikely to belong to Kiaeromena, which is known only from the Baltic. Cooper (1956) described eight species of B. (Bellimurina) from the Caradoc of Laurentia, of which he named six, but the dorsal interiors do not match $B$. (B.) sarytumensis, nor do those of $B$. (B.) rudis $\mathrm{Xu}$, Rong \& Liu (1974) from the early Caradoc Shitzupu Formation of South China. B. (B.) quadrata Fu (1982) appears more quadrate in outline and its interior is not illustrated (see also under Limbimurina? sp. below).

\section{Genus TERATELASMELLA Laurie, 1991}

TYPE SPECIES. Teratelasmella plicata Laurie, 1991, from the Upper Cashions Creek Limestone (Lower Caradoc), Tasmania, Australia.

\section{Teratelasmella chugaevae sp. nov. Pl. 2, figs 10-20; Figs} $10,11$.

ETYMOLOGY. In memory of the late Marina Chugaeva to honour her outstanding trilobite work.

HolotyPe. BC 57392, Pl. 2, figs 14-18, conjoined valves, from the Anderken Formation, Sample 626, Anderkenyn-Akchoku section.

MATERIAL. 16 pairs of conjoined valves and 3 dorsal valves from the Anderkenyn-Akchoku section, Samples 100 (BC 56842-51, BC 57390-91) and 626 (BC 56853-57, 57392); Kujandysai section, Samples 628 (BC 56858) and 85258 (BC 56852).

DESCRIPTION. Shell strongly dorsibiconvex, transverse, suboval, about $70 \%$ as long as wide, with maximum width at mid-length, and 


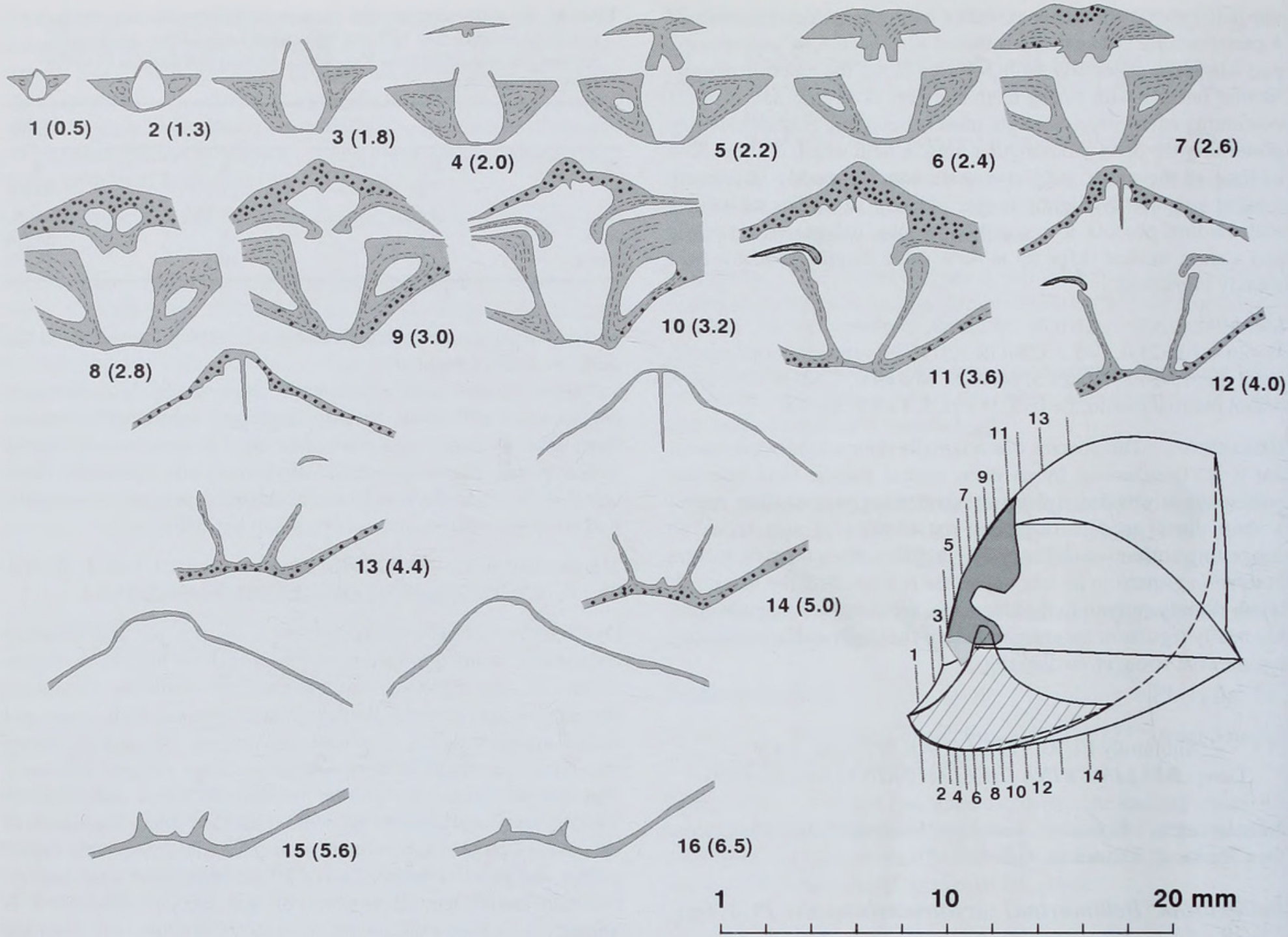

Fig. 10 Transverse serial sections of conjoined valves of Teratelasmella chugaevae sp. nov. from Sample 100. Distance in mm is measured from the posterior tip of ventral beak. Dorsal valve uppermost. Also lateral view to show section positions and schematic reconstruction.

$90 \%$ as thick as long. Anterior commissure strongly uniplicate. Ventral valve moderately convex with maximum thickness near quarter valve length. Interarea high, triangular, apsacline with delthyrium completely covered by pseudodeltidium perforated by a small umbonal foramen. Ventral sulcus originating at the umbonal area, strongly deepening anteriorly and ending with prominent, semielliptical tongue inclined at less than a right angle to the commissural plane. Flanks of the valve flattened, slightly inclined to the commissural plane. Dorsal valve very strongly convex, with a low, anacline interarea. Strong median fold, rounded in cross-section, with steep lateral slopes originating near the beak. Very weak and narrow dorsal median sulcus in the umbonal area of some specimens. Radial ornament coarsely parvicostellate with 5 ribs per $3 \mathrm{~mm}$ along the posterior margin of mature specimens.

Interiors of both valves were studied in transverse sections (Figs $10,11)$. Ventral valve with strong teeth supported by high dental plates continuing anteriorly as muscle bounding ridges. Low median ridge in the anterior half of the ventral muscle field. Dorsal valve interior with bilobed cardinal process and low, curved socket ridges. Median septum high, triangular, blade-like, extending anteriorly to mid-valve, flanked laterally by a pair of short side septa. Adductor field raised anteriorly and bordered by a high rim.

DISCUSSION. This species is similar only to Teratelasmella plicata
Laurie, 1991, but it can be distinguished in being larger (up to 25.6 mm wide), with a strongly dorsibiconvex lateral profile, a deep ventral sulcus, a high dorsal median fold originating in the umbonal area rather than at the mid-valve as in the type species, and coarser radial ornament.

Furcitellinae gen. et sp. indet.

$$
\text { Pl. 1, figs } 30,31 \text {, Pl. 2, figs } 1-4
$$

MATERIAL. Four pairs of conjoined valves, two ventral and six dorsal valves from Samples 100 (BC 56859, 57382, 57384) and 626, Anderkenyn-Akchoku section; Sample 628 (BC 56577, 56863, 57381) and 8220 (BC 56578), Kujandysai section; Sample 1041a (BC 56860-62, 57383), Burultas Valley.

DESCRIPTION. Shell convexoplane, transverse, subrectangular in outline with maximum width near mid-length. Cardinal extremities nearly right angled. Anterior commissure rectimarginate. Ventral valve almost flat with acute and slightly erect beak. Ventral interarea low apsacline with convex pseudodeltidium. Dorsal valve evenly convex with low, orthocline interarea and well-developed chilidium. Radial ornament parvicostellate. Up to $10 \mathrm{~mm}$ from the umbo the ribs are nearly equal in size and are $7-9$ per $3 \mathrm{~mm}$. In larger specimens 2-5 finer costellae become inserted between the larger 

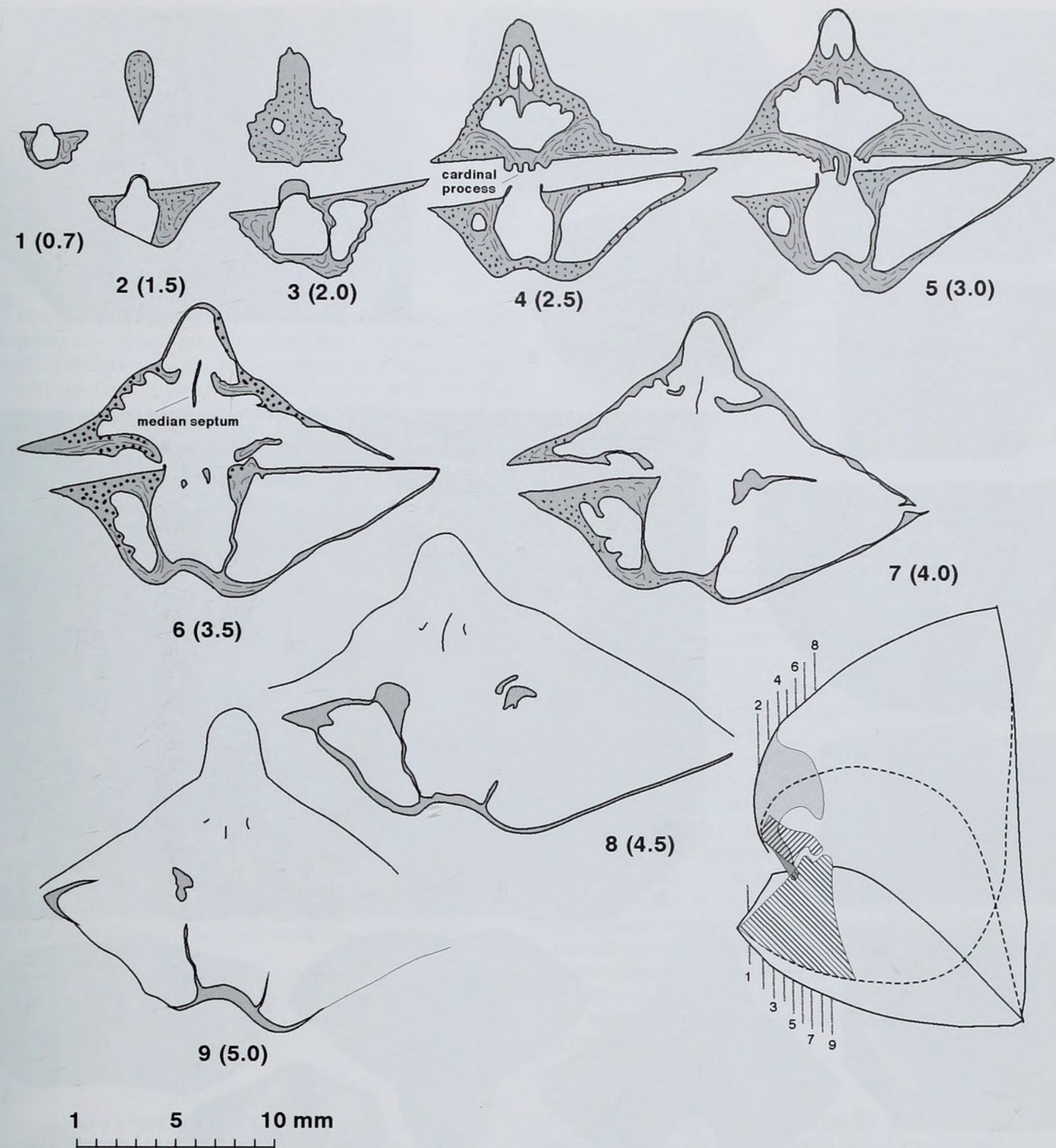

Fig. 11 Transverse serial sections of Teratelasmella chugaevae sp. nov. from Sample 100. Distance in mm is measured from the posterior tip of ventral beak. Dorsal valve uppermost. Also lateral view to show section positions and schematic reconstruction.

ribs and ornament becomes unequally parvicostellate, with up to 4 accentuated ribs and 9-15 parvicostellae per $3 \mathrm{~mm}$ along the anterior margin.

Ventral interior with delicate teeth and long, divergent dental plates. Ventral muscle field subtriangular, open anteriorly. Dorsal interior with bilobed cardinal process. Other characters of dorsal interior unknown.

DisCUSSION. Within the Furcitellidae as revised by Cocks \& Rong (2000) these shells are comparable with Quondongia (Percival 1991:151) and Molongcola (Percival 1991:153) from the Caradoc of
Australia in their planoconvex lateral shell profile and in the absence of geniculation, but they differ from Molongcola in possessing parvicostellate ornament. The absence of information on the dorsal interior makes precise generic attribution impossible.

\section{Family GLYPTOMENIDAE Cooper, 1956 Genus GLYPTOMENA Cooper, 1956}

TYPE SPECIES. Glyptomena sculpturata Cooper, 1956, from the Chatham Hill Formation (Llandeilo), Virginia, U.S.A. 

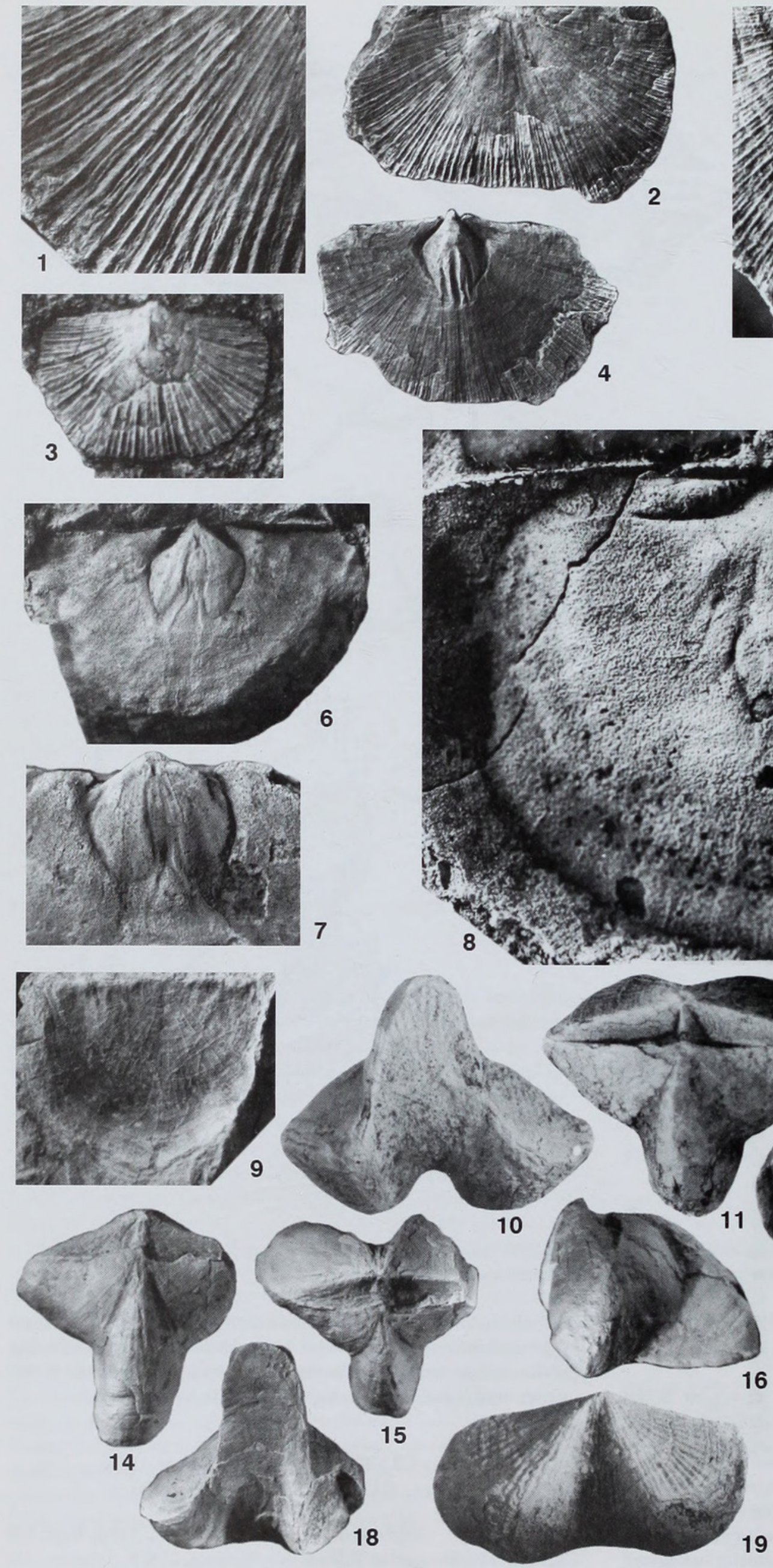
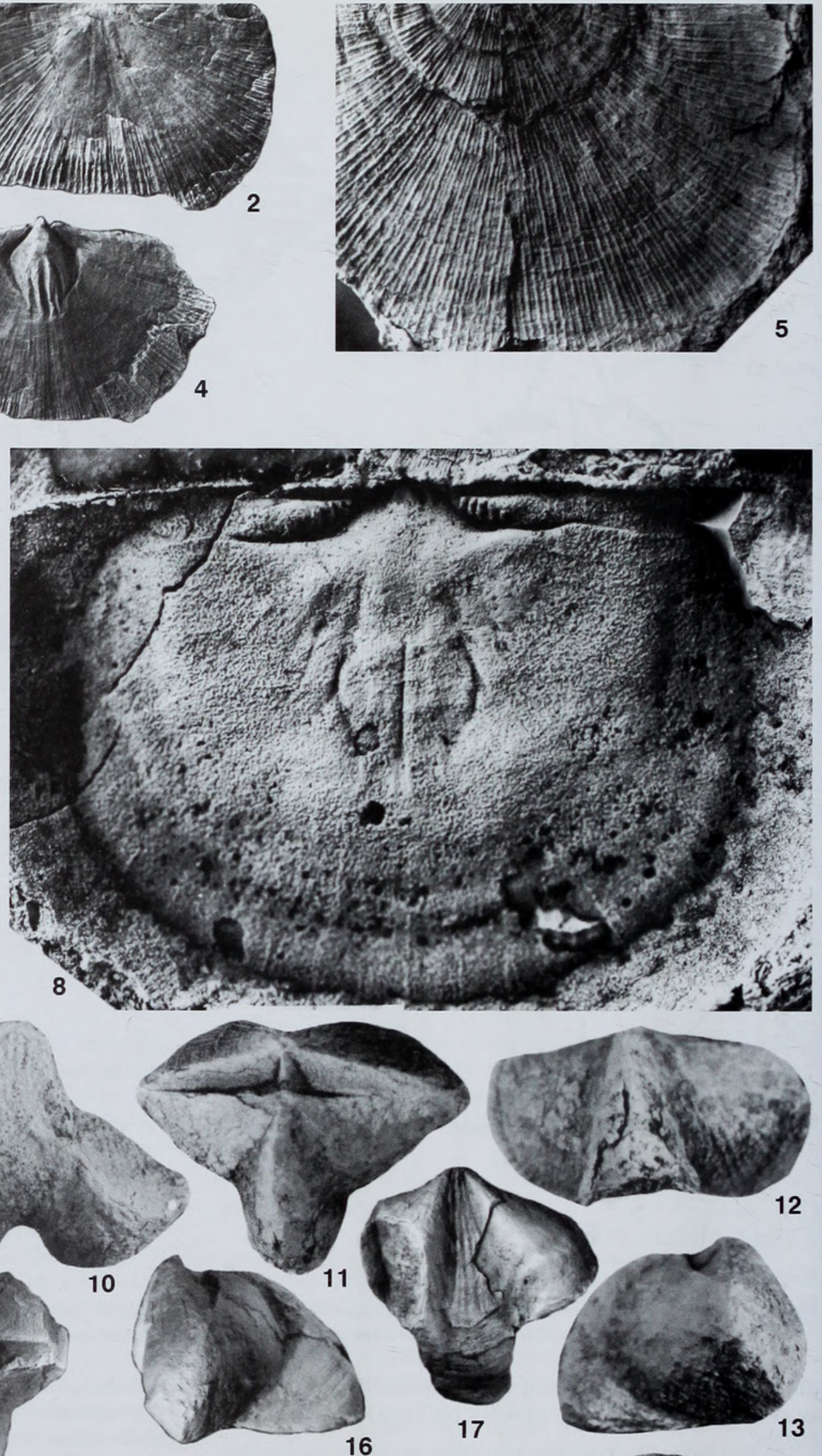

5 
Glyptomena onerosa Popov, 1980

Pl. 2, figs 5-9

1980

Glyptomena onerosa Popov: 152, pl. 2, figs 5-7.

HoLOTYPE. CNIGR 50/11523, Anderken Formation, from Sample 100b, Anderkenyn-Akchoku section.

MATERIAL. 14 ventral and 24 dorsal valves from Samples 100b, 843 (BC 57387), 8135, 8137, 8235 (BC 57386), AnderkenynAkchoku section; Sample 7613 (BC 57388), Kujandysai section; Samples 8229 (BC 57385), 8257 (BC 56864-65), BuldukbaiAkchoku section; Sample 1018, 7 km SW of Karpkuduk well, Kotnak Mountains.

DESCRIPTION. Shell concavoconvex, semielliptical in outline, about $60 \%$ as long as wide, with maximum width at the hinge line. Cardinal extremities slightly acute. Anterior commissure rectimarginate. Ventral valve moderately convex in lateral profile with maximum thickness at about one-third valve length. Ventral interarea low, apsacline, with small apical pseudodeltidium. Dorsal valve flattened with dorsal geniculation at about $75 \%$ of valve length from the umbo. Dorsal interarea low, anacline with well developed, broad, convex chilidium. Radial ornament inequally parvicostellate with up to three generations of accentuated ribs separated by $2-5$ parvicostellae in the interspaces. Number of ribs along the anterior margin of mature specimens varying from 11 to 15 per $3 \mathrm{~mm}$. Concentric ornament of fine, regularly spaced concentric fila, about 20-25 per mm.

Ventral interior with strong teeth bearing rows of crenulations on the outer side and long, widely divergent dental plates. Ventral muscle field heart-shaped about one-third as long as the valve with strongly impressed diductor scar somewhat longer, but not enclosing slightly raised, narrow triangular adductor track. Dorsal interior with bilobed cardinal process on a low notothyrial platform and widely diverging socket ridges subparallel to the hinge line. Sockets deep, transverse, bearing strong vertical ridges on the anterior slope. Adductor scars weakly impressed, bisected by the fine median septum extending anteriorly about $60 \%$ of valve length. Pair of inner side septa about the same length as the median septum, slightly divergent proximally and curved towards the anterior of the median ridge near the mid-valve. Outer side septa very fine or completely absent in some specimens.

DISCUSSION. This species is similar to Glyptomena sculpturata Cooper, 1956, but differs in having a geniculated dorsal valve and more densely accentuated ribs.

\section{Family LEPTAENIDAE Hall \& Clarke, 1894} Genus LIMBIMURINA Cooper, 1956

TYPE SPECIES. Limbimurina insueta Cooper, 1956, from the Nealmont Formation (Caradoc), Pennsylvania, U.S.A.
Limbimurina? sp.

Pl. 3, fig. 1

MATERIAL. One ventral and five dorsal valves from Samples 100, 626 (BC 57395), 8223b (BC 56867-68), Anderkenyn-Akchoku section; Samples 628 and 2538 (BC 56866), Kujandysai section.

DESCRIPTION. Shell flattened, transverse, subrectangular in outline; strongly geniculate ventrally with a trail up to $4 \mathrm{~mm}$ long inclined at nearly right angles to the commissural plane. Cardinal extremities nearly right angled. Ventral valve strongly flattened posteriorly to the geniculation, with gently convex umbonal area. Ventral interarea low, planar, apsacline with apical pseudodeltidium. Dorsal valve with strong angular concentric rugae accentuating the geniculation. Dorsal interarea anacline. Radial ornament unequally parvicostellate with 4-5 parvicostellae per $\mathrm{mm}$ along the anterior margin. Concentric ornament of oblique rugellae crossing each other at less than $30-40^{\circ}$ and covering all the valve surface between hinge line and geniculation. Interior of both valves unknown.

MEASUREMENTS. dorsal valve, $\mathrm{L}=14.1, \mathrm{~W}=29.0$.

Discussion. Generic assignment of the Kazakh specimens to Limbimurina is based mostly on the distinctive shell shape, with strong geniculation enhanced by the characteristic concentric frill and the irregular oblique rugellae forming an interference pattern with concentric rugae in the posterior half of the shell. The specimens from the Anderken Formation differ from Limbimurina brevilimbata Cooper, 1956 from the Edinburg Formation of Virginia and $L$. insueta Cooper, 1956 from the Rodman Formation of Pennsylvania in the strongly transverse outline of the shell. The trail in the Kazakh shells is considerably higher than in $L$. insueta, but not as high as in L. brevilimbata.

Similar shells were also described as Limbimurina? sp. from the Dulankara Regional Stage (Upper Caradoc) of north Betpak-Dala (Nikitin \& Popov 1996). They differ from the Anderken specimens in their more densely spaced parvicostellae, which vary from 11 to 14 per $\mathrm{mm}$ along the anterior margin.

A similar species is Bellimurina quadrata $\mathrm{Fu}, 1982$, from the Pinling Formation of Northwest China, which also possesses a geniculation as well as a characteristic concentric frill, and irregular oblique rugellae forming characteristic interference patterns; but precise comparision is difficult because of the short description and insufficient illustrations. It most likely belongs to Limbimurina, but no detailed information was provided on the dorsal interior ( $\mathrm{Fu}$ 1982:122, pl. 35, figs 20-21).

Family CHRISTIANIIDAE Williams, 1952 Genus CHRISTIANIA Hall \& Clarke, 1892

TYPE SPECIES. Leptaena subquadrata Hall, 1883, from the Caradoc of the U.S.A.

\section{PLATE 2}

Figs 1-4 Furcitellinae gen. et sp. indet. 1, 2, 4. Sample 100, Anderkenyn-Akchoku section; 1, 2, BC 57382, dorsal radial ornament and exterior, $\times 5, \times 2$; 4, BC 57384, ventral internal mould, $\times 2$. 3, Sample 1041a, Burultas Valley, BC 57383, ventral exterior, $\times 2.5$.

Figs 5-9 Glyptomena onerosa Popov. 5, Sample 7613, Akchoku Mountain, Kujandysai section, BC 57388, dorsal valve ornament, $\times 3.6$, Sample 8229, Buldukbai-Akchoku section, west side of Kopalysai, BC 57385, ventral internal mould, × 2. 7, Sample 8235, Anderkenyn-Akchoku section, BC 57386, ventral internal mould, $\times 3.8$, Sample 100b, Anderkenyn-Akchoku section, CNIGR Museum, dorsal internal mould, $\times 4.9$, Sample 843 , AnderkenynAkchoku section, BC 57387, dorsal exterior, $\times 1.5$.

Figs 10-20 Teretelasmella chugaevae sp. nov. Anderkenyn-Akchoku section. 10-13, 19, 20, Sample 100; 10-13, 19, BC 57391, conjoined valves, anterior, posterior, dorsal, lateral and ventral views, $\times 1.5 ; \mathbf{2 0}$, BC 57390, conjoined valves, posterior view, $\times 2$. 14-18, Sample 626, BC 57392, conjoined valves, holotype, dorsal, posterior, lateral, ventral and anterior views, $\times 1.5$. 


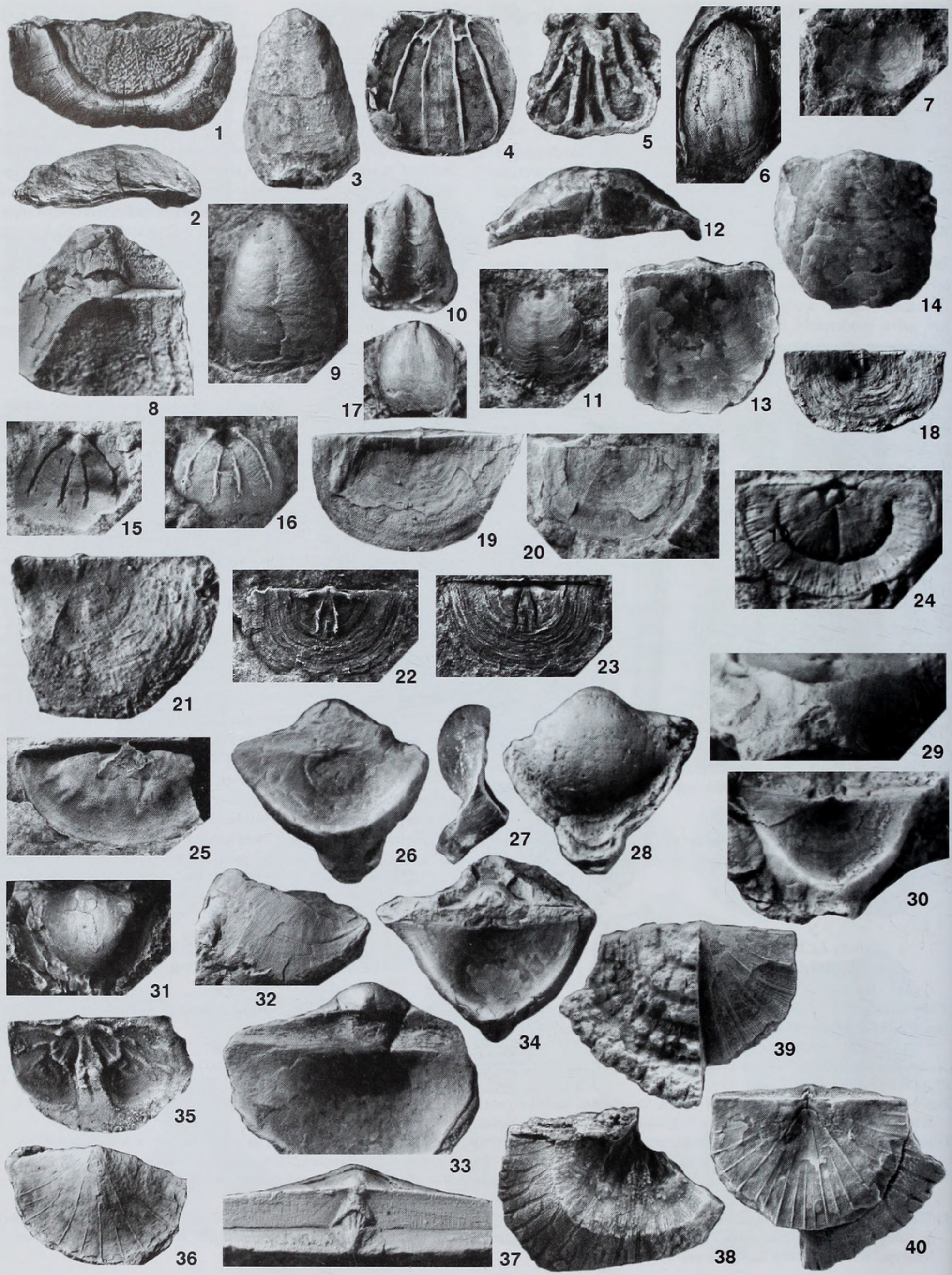




\section{Cristiania egregia Popov, 1985}

Pl. 3, figs $2-6,8$

1985 Christiania egregia Popov: 60, pl. 2, figs 7-11.

HOLOTYPE. CNIGR 25/11989, dorsal internal mould from the Anderken Formation, Sample 1018, 7 km south-west of Karpkuduk Well, Kotnak Mountains.

MATERIAL. Eight pairs of conjoined valves, 17 ventral and 30 dorsal valves from Samples 100 (BC 56875-81), 843, 626 (BC 56869-70), 8214 (BC 56871-2), Anderkenyn-Akchoku section; Samples 7613, 628 (BC 56587, 56886-89), Kujandysai section; Sample 1041a (BC 57396-98), Burultas Valley; Sample 1024b, east side of Karatal River near Sorbulak well; Sample 1018 (BC 5687374), 7 km south-west of Karpkuduk well, Kotnak Mountains.

DESCRIPTION. Shell concavoconvex, strongly elongated, suboval in outline, about $160 \%$ as long as wide with maximum width about two-thirds valve length from the hinge line. Cardinal extremities subrectangular, usually slightly alate. Anterior commissure broadly uniplicate. Ventral valve moderately convex in lateral profile with maximum thickness at about one-third valve length, about $20 \%$ as thick as long. Ventral interarea strongly apsacline to orthocline with a large convex pseudodeltidium perforated apically by a minute, circular foramen. Very weak ventral sulcus originating at the umbonal area. Dorsal valve gently concave with hypercline interarea and complete, convex chilidium. Radial ornament finely parvicostellate, rarely preserved.

Ventral interior with strong, transverse teeth and low, widely diverging dental plates. Muscle field weakly impressed, bilobate, with short, linear adductor scars bisected by a fine median ridge. Dorsal interior with bilobed cardinal process, low, curved socket ridges subparallel to the hinge line and two pairs of strong side septa. Dorsal median septum very fine, about $61 \%$ as long as the valve. Adductor scars bordered anteriorly by strong muscle bounding ridges curved posteriorly.

DISCUSSION. Detailed discussion of this species was provided by Popov (1980: 61). Among the Kazakh species it is most similar to Christiania tortuosa Popov, 1980 from the Lidievka Formation (Llandeilo-Lower Caradoc) of north-central Kazakhstan, but differs in having a weak ventral sulcus, very fine radial ornament and a long dorsal median ridge extending far beyond the mid-valve. There are a large number of nominal Christiania species known globally, and the genus as a whole is due for revision.

Christiania aff. sulcata Williams, 1962 Pl. 3, figs 7, 9-17

MATERIAL. Three pairs of conjoined valves, 23 ventral and 10 dorsal valves from Samples 8223 (BC 56585-6), 8223a, 8223b (BC 57399, 57401), Anderkenyn-Akchoku section; Sample 8215 (BC 56583-4), west side of Ashchisu River; Samples 628 (=K-107/1970) (BC 56593), 2538 (BC 56579, 81, 89), 8217 (BC 57400), 8220 (BC 56592), Kujandysai section.

DESCRIPTION. Shell concavoconvex, elongate and subtrapezoidal in outline, as long as wide with maximum width at three-quarters valve length. Hinge line about $85 \%$ of maximum shell width. Cardinal extremities near right-angled and slightly alate. Lateral commissures near straight, slightly diverging anteriorly. Anterior commissure gently uniplicate. Ventral valve strongly convex in profile with maximum thickness at about one-third valve length. Ventral interarea strongly apsacline to near orthocline with narrow convex pseudodeltidium perforated apically by a minute rounded foramen. Lateral sides of the valve steep inclined near right angle towards the commissural plane. A shallow sulcus $\mathrm{v}$-shaped in crosssection originating near the umbo and flanked by two distinct plications rounded in cross-section. Dorsal valve moderately concave with low and narrow median fold. Dorsal interarea hypercline with a convex chilidium. Shell surface finely and equally parvicostellate with 16 to 18 parvicostellae along the anterior margin of mature specimens.

Ventral interior with small, bilobed muscle field, fine teeth and rudimentary dental plates. Dorsal interior with a double cardinal process, low, curved socket ridges, thin median septum extending somewhat anterior of mid-valve and two pairs of strong side septa.

MEASUREMENTS. (457/12375) ventral valve, $\mathrm{L}=8.2$, $\mathrm{Iw}=5.7$, $\mathrm{W}=6.8, \mathrm{~T}=3.8, \mathrm{Sw}=3.2 ; 458 / 12375$ ), dorsal valve, $\mathrm{L}=5.6, \mathrm{Iw}=5.2$, $\mathrm{W}=5.3, \mathrm{Sw}=2.2$

Discussion. These specimens resemble Christiania sulcata Williams, 1962, from the Stinchar Limestone (Upper Llandeilo-

\section{PLATE 3}

Fig. 1 Limbimurina sp. Sample 626, Anderkenyn-Akchoku section, BC 57395, ventral exterior, $\times 1.5$.

Figs 2-6, 8 Christiania egregia Popov. 2, 3, Sample 1041a, Burultas Valley, BC 57396, lateral and ventral views of exterior, $\times 2$. 4, Sample 1018, area 7 km west of Karpkuduk well, Kotnak Mountains, south Betpak-Dala, CNIGR 22/11989, latex cast of dorsal interior, × 2. 5, Sample 1041a, BC 57397, dorsal valve interior, $\times 2$. 6, Sample 1018, CNIGR 23/11989, ventral internal mould, $\times 2$. 8, Sample 1041a, BC 57398, conjoined valves dorsal view showing interareas, $\times 4$.

Figs 7, 9-17 Christiania aff. sulcata Williams. 7, Sample 628, west side of Kujandysai, BC 56593, dorsal exterior, $\times 4$. 9, Sample 8223b, AnderkenynAkchoku section, BC 57399, ventral exterior, $\times 3$. 10, Sample 8217, BC 57400, ventral exterior, $\times 3$. 11-16, Sample 2538, Akchoku Mountain,

Kujandysai section; 11, BC 56589, dorsal external mould, $\times 3$; 12-14, BC 56579, conjoined valves, posterior view, $\times 8$, dorsal and ventral views, $\times 6$; 15, 16, BC 56581, dorsal internal mould and latex cast, $\times 5.17$, Sample $8223 \mathrm{~b}$, BC 57401, ventral internal mould, $\times 3$.

Figs 18-23, 25 Foliomena prisca sp. nov. 18, 19, 21-23, Sample 8255, Anderkenyn-Akchoku section; 18, BC 57402, latex cast of dorsal exterior, $\times 4$; 19, BC 57403, latex cast of dorsal exterior, $\times 4 ; \mathbf{2 1}$, BC 57404, latex cast of dorsal exterior, $\times 4 ; \mathbf{2 2}, \mathbf{2 3}$, BC 57405 , holotype, latex cast and dorsal internal mould, $\times$ 4. 20, Sample 100, Anderkenyn-Akchoku section, BC 57407, dorsal exterior, $\times 4$. 25, Sample 8217, Kujandysai section, BC 57408, ventral internal mould, $\times 4$.

Fig. 24 Kassinella (Kassinella)? sp. Sample 2531, Anderkenyn-Akchoku section, BC 56497, dorsal internal mould, $\times 8$.

Figs 26-34 Craspedelia tata Popov. 26-28, Sample 626, Anderkenyn-Akchoku section, BC 57409, conjoined valves, dorsal, lateral and ventral views, $\times 4$. 29-30, Sample 100, BC57410, dorsal exterior and anterior views, $\times 3.31$, Sample 8238, CNIGR 9/12361, ventral exterior, $\times 2.32-34$, Sample 626; 32, 34, BC 57411, dorsal anterior and exterior view, $\times 3$; 33, BC 57412, conjoined valves, dorsal view, $\times 5$.

Fig. 35 Isophragma imperator Popov, Sample 1018, 7 km southwest of Karpkuduk well, Kotnak Mountains, south Betpak-Dala, CNIGR 22/11522, latex cast of dorsal interior, $\times 2$.

Figs 36-40 Acculina kulanketpesica sp. nov. 36, Sample 8231-40, Buldukbai-Akchoku section, BC 57416, ventral exterior, $\times 2$. 37-40, Sample 1041a, Burultas Valley; 37, BC 57415, posterior view of ventral and dorsal interareas, $\times 5 ; 38$, BC 12903, ventral interior, $\times 2 ; 39, \mathbf{4 0}$, BC 12904, holotype, conjoined valves, ventral and dorsal views, $\times 3$. 
Table 9 Measurements of ventral valves of Christiania aff. sulcata Williams, Parastrophina-Kellerella Association, Anderkenyn-Akchoku and Kujandysai sections.

\begin{tabular}{lllllccc}
\hline & Lv & W & Iw & Sw & Lv/W & Iw/W & Sw/W \\
\hline $\mathrm{N}$ & 9 & 9 & 6 & 5 & 9 & 6 & 5 \\
$\mathrm{X}$ & 6.5 & 5.6 & 4.8 & 2.5 & $115.0 \%$ & $87.8 \%$ & $42.9 \%$ \\
$\mathrm{~S}$ & 1.91 & 1.15 & 0.85 & 0.73 & 16.1 & 6.4 & 12.4 \\
$\mathrm{MIN}$ & 4.0 & 4.4 & 3.9 & 1.7 & $90.9 \%$ & $82.8 \%$ & $23.0 \%$ \\
$\mathrm{MAX}$ & 9.4 & 7.4 & 6.3 & 3.2 & $147.5 \%$ & $100.0 \%$ & $54.2 \%$ \\
\hline
\end{tabular}

Lower Caradoc) of Girvan, Scotland, but differ in having an elongate subtrapezoidal shell outline and two rounded plications flanking the ventral sulcus. A characteristic feature of the Kazakh specimens is the absence of high ridges bordering the dorsal adductor field anteriorly, which also appear to be absent in $C$. sulcata (Williams 1962: pl. 18, fig. 36). Christiania aff. sulcata also differs from $C$. egregia in having a stronger ventral median sulcus which is $\mathrm{v}$-shaped in cross-section, a distinctive dorsal median fold and significantly smaller size.

\section{Family FOLIOMENIDAE Williams, 1965 Genus FOLIOMENA Havlícek, 1952}

TYPE SPECIES. Strophomena folium Barrande, 1879, from the Králův Dvůr Formation (Ashgill) of Bohemia.

\section{Foliomena prisca sp. nov.}

Pl. 3, figs $18-23,25$

ETYMOLOGY. After priscus, Latin - old.

HolotyPE. BC 57405, Pl. 3, figs 22, 23, a dorsal valve, from the Anderken Formation, Sample 8255, Anderkenyn-Akchoku section.

MATERIAL. 2 pairs of conjoined valves, 4 ventral and 3 dorsal valves from Samples 100 (BC 57407), 2531, 8221 (BC 56890), 8223b, 8251, 8255 (BC 57402-06, 08), Anderkenyn-Akchoku section; 628, 2538, 8217, Kujandysai section.

DESCRIPTION. Shell flat and gently resupinate, transverse, subrectangular in outline, about $60 \%$ as long as wide, with maximum width at hinge line. Cardinal extremities near right angled. Anterior commissure rectimarginate. Ventral valve gently convex in the posterior half and weakly concave anteriorly. Ventral interarea apsacline with a minute, apical pseudodeltidium. Dorsal valve with lateral profile flat to slightly concave in the posterior half and convex posteriorly, with maximum thickness at about three-quarters valve length in mature specimens. Dorsal interarea linear, anacline, with separate chilidial plates flanking narrow notothyrium. Radial ornament of fine capillae rarely preserved. Concentric ornament of numerous slightly uneven fine rugellae.

Ventral interior with delicate teeth lacking dental plates and an open, weakly impressed muscle field. Dorsal interior with a small bilobed cardinal process in the low notothyrial platform and thin widely diverging socket ridges. Thin median septum, about half the length of the pair of strong curved side septa.

MEASUREMENTS. (463/12375) ventral valve, $\mathrm{L}=6.0, \mathrm{~W}=11.7 ;$ (464/ $12375)$ ventral valve, $\mathrm{L}=6.4, \mathrm{~W}=11.4$; (466/12375) dorsal valve, $\mathrm{L}=4.3, \mathrm{~W}=7.2 ;(468 / 12375)$ dorsal valve, $\mathrm{L}=4.6, \mathrm{~W}=8.5 ;(469 / 12375)$ dorsal valve, $\mathrm{L}=3.6, \mathrm{~W}=6.3$.

Discussion. Cocks \& Rong (1988:65) discussed the variation in the ornament of Foliomena and noted that, although all the shells from the type locality in Bohemia were devoid of radial ornament, occasional costae or costellae can be present sporadically in some populations. The presence of fine capillae is a key feature in our new species, as is the resupinate shell shape and the separate chilidial plates, although the features within the interarea are poorly known in Foliomena folium. It is difficult to make a precise comparison of our shells with $F$. inelegans Fu, 1982 from the Pingliang Formation (Upper Caradoc) of North China, because of inadequate information on the interior of the latter species. From $F$. jielingensis, described by Zeng (1987) from the Miapo Formation (Lower Caradoc) of the Yangtze Gorge area, south China, F. prisca differs in the presence of the fine ornament, the resupinate shell shape and in the absence of the ventral internal tuberculae seen in F. jielingensis.

\section{Superfamily PLECTAMBONITOIDEA Jones, 1928 Family PLECTAMBONITIDAE Jones, 1928 Subfamily TAPHRODONTINAE Cooper, 1956 Genus ISOPHRAGMA Cooper, 1956}

TYPE SPECIES. Isophragma ricevillense Cooper, 1956, from the Lower Caradoc of Tennessee, U.S.A.

Isophragma imperator Popov, 1980

Pl. 3, fig. 35

1980 Isophragma imperator Popov: 147, pl. 2, figs 8-12.

Holotype. CNIGR 25/11523, from Sample 1018, 7 km south-west of Karpkuduk Well, Kotnak Mountains.

MATERIAL. One pair of conjoined valves, 36 ventral and 34 dorsal valves from Sample 1018.

Discussion. Popov (1980) provided detailed description and discussion of this species.

Family BIMURIIDAE Cooper, 1956

Genus CRASPEDELIA Cooper, 1956

TYPE SPECIES. Craspedelia marginata Cooper, 1956: 773, pl. 213, figs. 1-20, from the Pratt Ferry Formation (Landeilo), Alabama, U.S.A.

Craspedelia tata Popov, 1980

Pl. 3, figs 26-34

1980 Craspedelia tata Popov: 55, pl. 17, figs 6-9.

1986 Craspedelia tata Popov; Kolobova \& Popov: pl. 1, fig. 9.

HoLOTYPE. CNIGR 8/11098, from the Lidievka Formation (Lower Caradoc), Belyi Kardon, north-central Kazakhstan.

MATERIAL. 25 pairs of conjoined valves, 18 ventral and 5 dorsal valves from Samples 100 (BC 56900-03, 57410, 57597) (=K98/ 1970), 626 (BC 56532, 56907-10, 57409, 57411-12), 8223a (BC 56935), 8223b, Anderkenyn-Akchoku section; Samples 8214 (BC 56925-30, 56932-33, 57598), 8215b (BC 56931), west side of Ashchisu River; Samples 628 (BC 56911), 2538 (BC 56917-24), Kujandysai section; Sample 8231-40, Buldukbai-Akchoku; Sample 948 (BC 56912-16), Tesik River.

DESCRIPTION. Shell smooth, concavoconvex posteriorly, strongly geniculated ventrally with a trail up to $8 \mathrm{~mm}$ long which curves back postero-ventrally; semielliptical in outline, about $80 \%$ as long as wide, with maximum width slightly anterior to hinge line. Cardinal extremities rounded. Anterior commissure uniplicate. Ventral valve strongly convex posteriorly with maximum thickness about onethird anteriorly. Narrow and shallow sulcus anterior to the 
geniculation. Dorsal valve strongly concave with low, planar interarea and notothyrium covered by joined apical chilidial plates. Weak median fold originating anterior to the geniculation. Shell surface smooth with fine growth lines. Ventral interior with strong teeth and vascula media subparallel. Dorsal interior with simple, undercut cardinal process, divided bema, low median ridge and a pair of slightly diverging side ridges bisecting the bema.

Discussion. This species differs from Craspedelia marginata Cooper (1956) and C. gabata Williams (1962: 179), from the Lower Ardwell Formation (Middle Caradoc) of Girvan, in its high (up to 8 $\mathrm{mm}$ ) ventrally directed trail with a well-defined ventral sulcus and dorsal median fold. It differs from $C$. intonsa Potter, 1991, from Member 1 of the Gregg Ranch Unit (Llandeilo), of California, USA, in having a larger shell, up to $12 \mathrm{~mm}$ long, with a less transverse outline and a high trail, which exceeds the thickness of the ventral valve in mature specimens.

Family LEPTELLINIDAE Ulrich \& Cooper 1936 Subfamily LEPTELLININAE Ulrich \& Cooper 1936 Genus ACCULINA Misius, in Misius \& Ushatinskaya,1977

TYPE SPECIES. Acculina acculica Misius in Misius \& Ushatinskaya, 1977, from the Tabylgaty Formation (Lower Caradoc: gracilis Zone), Moldo-Too Range, North Kirgyzstan.

\section{Acculina kulanketpesica sp. nov. Pl. 3, figs 36-40, Pl. 4,} figs $1-5$

ETYMOLOGY. After Kulanketpes ('donkey cannot escape' in Kazakh) Valley on the way from Lake Balkhash to the type locality.

HolotyPE. BC 12904, Pl. 3, figs 39, 40, conjoined valves, from the Anderken Formation, Sample 1041a, Burultas section.

MATERIAL. 50 pairs of conjoined valves, 13 ventral and 10 dorsal valves from Samples 100 (=K98/1970) (BC 56493-5, 56485-90, BC 57414), 620 (BC 56937-39), 626, 8128, Anderkenyn-Akchoku section; Sample 8231-40 (BC 57416, 18), Buldukbai-Akchoku, Sample 1041a (BC 12900-7, 57413, 15, 19), Burultas Valley; Samples 85258 (BC 56491-2, 56941-6), 2538 (BC 56501-02), Kujandysai.

DESCRIPTION. Shell resupinate, transverse, semielliptical in outline, about $70 \%$ as long as wide and $35 \%$ as thick as long. Cardinal extremities near right-angled or slightly acute. Anterior commissure rectimarginate. Ventral valve gently to moderately concave in the anterior half and slightly convex posterior to the mid-valve. Ventral interarea apsacline with a narrow, convex pseudodeltidium. Dorsal valve flat and gently sulcate between the umbo and mid-length, becoming moderately convex anteriorly. Interarea anacline with a narrow, convex chilidium completely covering the notothyrium. Radial ornament unequally parvicostellate with 7 accentuated costae in the umbonal area and 27-30 accentuated costellae along the

Table 10 Basic statistics of complete shells of Acculina kulanketpesica sp. nov. from Sample F-1041a, Burultas valley.

\begin{tabular}{lccclccc}
\hline & $\mathrm{Lv}$ & $\mathrm{Ld}$ & $\mathrm{W}$ & $\mathrm{T}$ & $\mathrm{Lv} / \mathrm{W}$ & $\mathrm{Ld} / \mathrm{W}$ & $\mathrm{T} / \mathrm{Lv}$ \\
\hline $\mathrm{N}$ & 6 & 5 & 6 & 5 & 6 & 5 & 5 \\
$\mathrm{X}$ & 15.5 & 14.7 & 22.6 & 5.4 & $68.9 \%$ & $65.6 \%$ & $34.5 \%$ \\
$\mathrm{~S}$ & 0.89 & 0.92 & 0.85 & 1.13 & 1.9 & 2.1 & 7.0 \\
MIN & 14.0 & 13.5 & 21.3 & 3.8 & 65.7 & 63.4 & 24.1 \\
MAX & 16.4 & 16.1 & 23.5 & 7.0 & $71.2 \%$ & $68.5 \%$ & $42.9 \%$ \\
\hline
\end{tabular}

anterior and lateral margins in full grown specimens. Interspaces between the accentuated costellae occupied by fine parvicostellae about $7-10$ per $\mathrm{mm}$ along the anterior margin. Fine, closely spaced growth lamellae form comae crossed by accentuated ribs in the anterior half of the shell.

Ventral valve with strong teeth with central grooves; lacking dental plates. Ventral muscle field small, rounded pentagonal with strongly impressed diductor scars completely divided by slightly shorter, narrow, triangular adductor scars. Ventral mantle canals saccate with slightly diverging vascula media. Dorsal valve interior with trifid cardinal process situated on the low notothyrial platform. Socket ridges low, widely diverging and slightly incurved posteriorly. Dorsal adductor muscle field subquadrate, bordered laterally by low, subparallel ridges. Median ridge high and strongly thickened, extended anteriorly to the mid-valve, merging with high diaphragm bordering the lophophore platform. Dorsal mantle canals lemniscate.

Discussion. This species also occurs in Betpak Dala, Kazakhstan (the locality in Nikitin \& Popov 1996). It differs from Acculina acculica Misius (in Misius \& Ushatinskaya 1977: 114) in its significantly larger shell, strongly convex anteriorly transverse profile of the dorsal valve and numerous comae (Pl. 3, fig. 39) in the anterior part of full grown specimens. It is also similar to $A$. villosa Nikitina (1985: 24) from the Rgaity Formation (Llandeilo-Lower Caradoc) of the Kendyktas Range, south Kazakhstan, in the development of comae, but can be distinguished in having a well-defined peripheral rim in the ventral valve, a somewhat smaller dorsal lophophore platform, which has a subrectangular, not a flabellate outline, and a pair of fine transmuscle ridges dividing the anterior and posterior adductors. Acculina is the only plectambonitoid in the Anderken Formation to possess comae, and its exterior is also normally covered by encrusting girvanellid algae. Two specimens (BC 56502-3, Pl. 4, figs 7,8) from the Kujandysai section from Sample 2538 differ from other Acculina in having a geniculate shell with the lophophore platform less than half the valve length, and probably represent a separate species.

\section{Genus DULANKARELLA Rukavishnikova, 1956}

TYPE SPECIES. Dulankarella magna Rukavishnikova 1956, from the Dulankara Formation (late Caradoc), Kazakhstan, Chu-Ili Range, Kazakhstan.

Dulankarella larga sp. nov. Pl. 4, figs 9-25, Pl. 5, figs 1-3 ETYMOLOGY. After largus, Latin-rich.

HolotyPE. BC 57421, Pl. 4, figs 9, 10, a dorsal valve interior from Anderken Formation, Sample 8231-40, Buldukbai-Akchoku section.

MATERIAL. 86 pairs of conjoined valves, 3 ventral and 2 dorsal valves, from Samples 100 (=K98/1970) (BC 56514, 16-18, 25-29, 57422, 24, 26), 626 (BC 56522-4), 8223a (BC 56511, 56975), Anderkenyn-Akchoku; Sample 8231-40(BC 57421, 23), BuldukbaiAkchoku; Sample 8228 (BC 56986), east side of Kopalysai River; Samples 1041a (BC 56512, 19-21, 56947-57), 818a, 1041a (BC 56967, 57425), Burultas Valley.

DESCRIPTION. Shell strongly concavoconvex, transverse and semielliptical in outline, on average $73 \%$ as wide as long, with maximum width at the hinge line and $45 \%$ as thick as long. Cardinal extremities slightly acute. Anterior commissure weakly sulcate. Ventral valve strongly and evenly convex in lateral profile, subcarinate posteriorly in transverse profile. Ventral interarea low, planar, anacline 

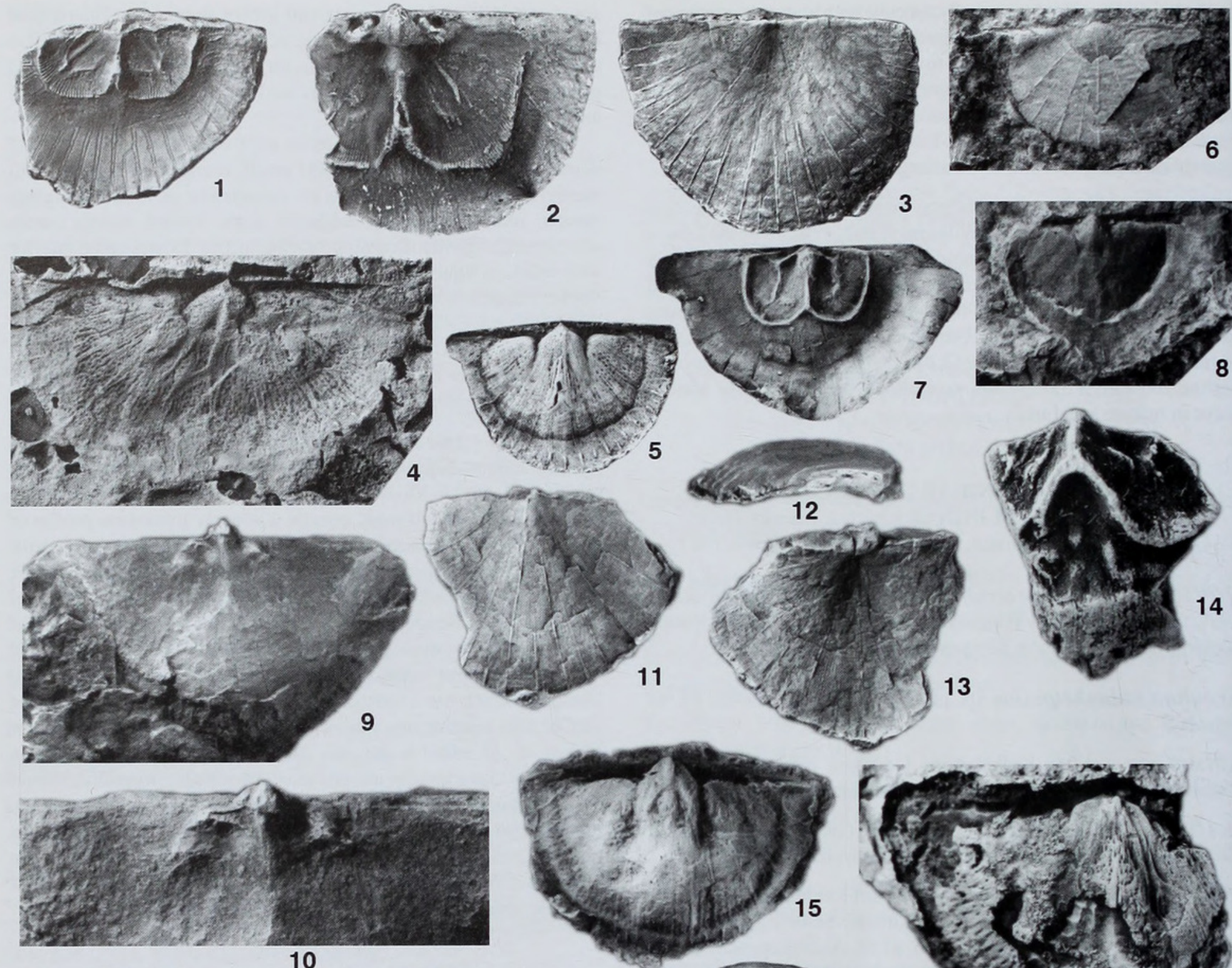

10
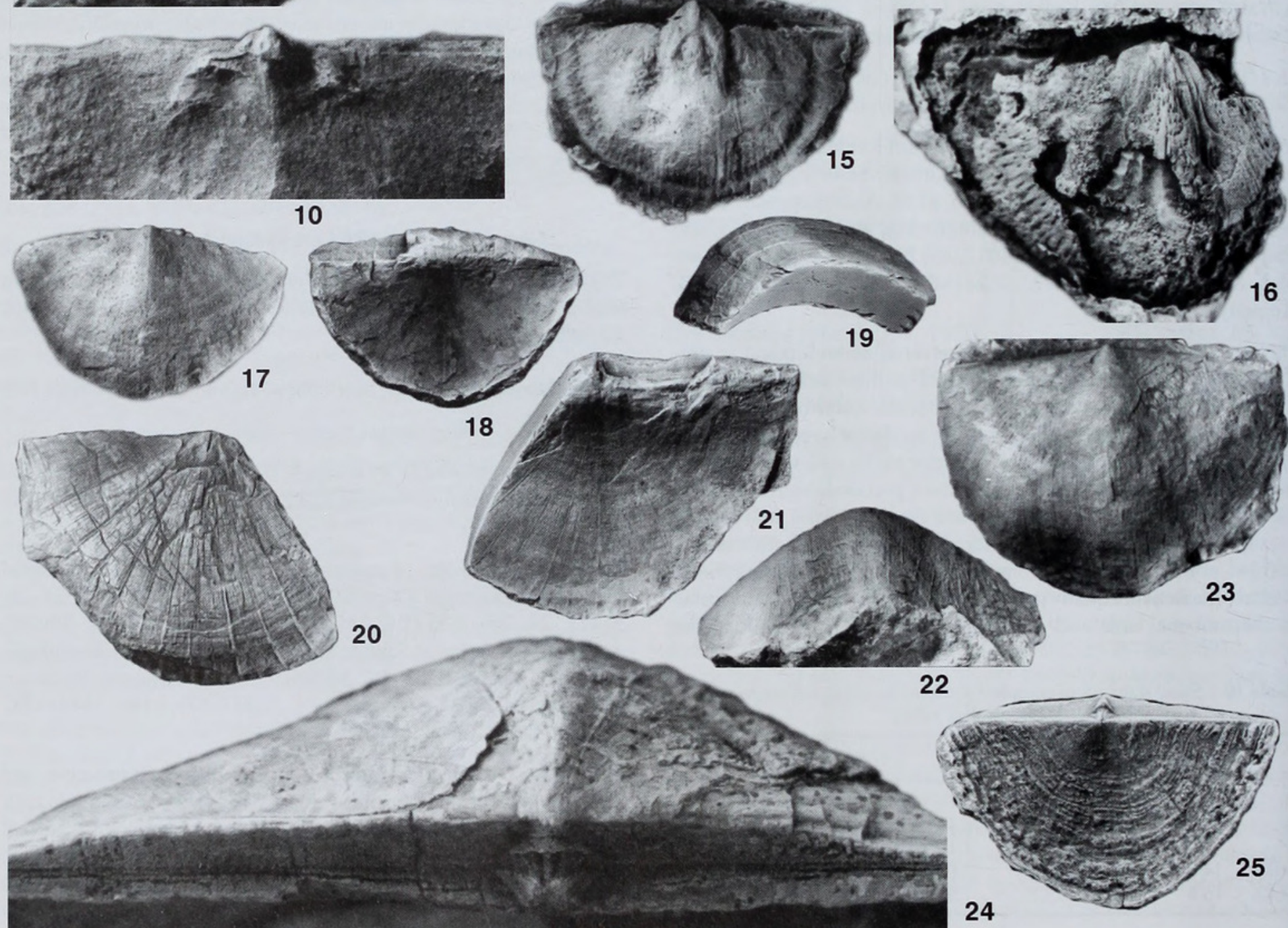

22

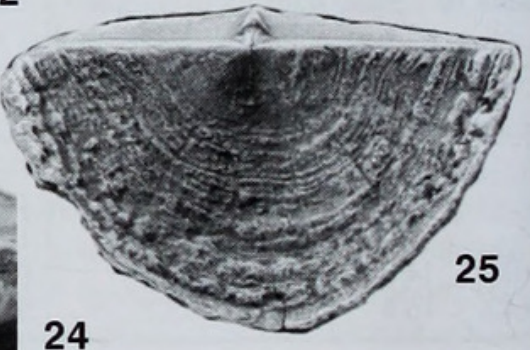


Table 11 Basic statistics of complete shells of Dulankarella larga sp. nov. from Sample F-1041a, Burultas valley.

\begin{tabular}{lcclcc}
\hline & Lv & W & T & Lv/W & T/Lv \\
\hline $\mathrm{N}$ & 9 & 9 & 7 & 9 & 7 \\
$\mathrm{X}$ & 16.9 & 24.6 & 7.7 & $69.7 \%$ & $46.1 \%$ \\
$\mathrm{~S}$ & 2.10 & 3.57 & 1.19 & 10.2 & 3.2 \\
$\mathrm{MIN}$ & 13.5 & 19.1 & 5.7 & $51.9 \%$ & $41.5 \%$ \\
MAX & 18.8 & 31.6 & 9.2 & $81.3 \%$ & $50.0 \%$ \\
\hline
\end{tabular}

with delthyrium partly covered by a convex pseudodeltidium. Dorsal valve strongly concave and slightly geniculate anteriorly. Dorsal interarea hypercline with chilidial plates joined apically. Sulcus broad and shallow, originating near mid-valve. Radial ornament unequally parvicostellate with 5-7 accentuated ribs originating at the umbo and two or three generations of accentuated costellae, totaling $31-38$ in number in full grown specimens. Parvicostellae between accentuated ribs very fine and closely spaced, about 12-16 per $\mathrm{mm}$ along the anterior margin.

Ventral valve interior with strong teeth supported by short dental plates, thickened at the base. Muscle field bilobed with strongly impressed, rounded subrhomboidal diductor scars separated by short, elongate subtriangular adductor scars. Paired nodose swellings anterolateral to the muscle field. Ventral mantle canals saccate with short, divergent vascula media. Dorsal interior with trifid cardinal process bearing a strong, ridge-like median lobe and up to 6 fine ridges on the lateral lobes. Socket ridges narrow, widely diverging. Median septum strongly raised and thickened anteriorly with the maximum height at the point of junction with the outer boundary of the lophopore platform accentuated by geniculation of the valve.

DisCUSSION. This species resembles the later Dulankarella magna Rukavishnikova (1956:139) in size and transverse profile, but differs in having a finer radial ornament with 5-7 strongly accentuated primary ribs and a characteristic rounded subrhomboidal outline of the ventral diductor scars, which only slightly touch each other anteriorly to the adductor scars. The differences from Dulankarella? partita Percival (1979b: 103) are in having a less transverse outline, evenly convex ventral valve, the ventral muscle field lacking a median ridge, and the rhomboidal outline of the ventral diductor scars.

Genus KAJNARIA Nikitin \& Popov, 1984

TYPE SPECIES. Kajnaria derupta Nikitin \& Popov in Klenina et al. (1984), from the Bestamak Formation (Lower Caradoc), Chingiz Range, Kazakhstan.
Kajnaria rugosa sp. nov.

Pl. 5, figs 6-18

ETYMOLOGY. After rugosus, Latin - wrinkled.

HolOTYPE. BC 56551, Pl. 5, figs 12, 13, a dorsal internal mould from Sample 628, Kujandysai section.

MATERIAL. 9 pairs of conjoined valves and three ventral valves from Samples 100 (BC 56545-47, 57436, 37), 626 (BC 56548), 8223a, Anderkenyn-Akchoku section; Sample 628 (=K107/1970) (BC 56551, 57439), Kujandysai section; Sample 1041a (BC 56543, 44), Burultas Valley: Sample 816 (BC 56549-50, 57438), Alakul lake.

DESCRIPTION. Shell strongly concavoconvex, semielliptical in outline, about $67-82 \%$ as long as wide with maximum width at the hinge line. Cardinal extremities acute and slightly alate in adult specimens. Ventral valve strongly convex in lateral profile, weakly geniculate in some specimens, with maximum thickness posterior to mid-length. Relatively weak umbo. Interarea anacline with narrow convex pseudodeltidium. Dorsal valve moderately and evenly convex with hypercline interarea. Notothyrium completely covered by convex chilidium. Radial ornament unequally parvicostellate with 5-7 primary accentuated ribs and two to three generations of accentuated costellae, with the interspaces between them covered by fine closely-spaced parvicostellae, about 7-14 per mm. Concentric ornament of up to 9 undulated rugellae in the posterior half of both valves.

Ventral interior with strong teeth lacking dental plates. Ventral muscle field small, strongly supported by raised muscle bounding ridges which merge centrally and anteriorly. A further pair of strong curved ridges originate posteriorly at one-third of the length of the hinge line on each side of the valve, and curve anterolaterally to form a w-shaped structure which terminates near the end of the bounding ridges at about quarter valve length. Mantle canals saccate with vascula media subparallel in the proximal part and diverging anteriorly. Dorsal interior with erect trifid cardinal process fused anteriorly to a strong median ridge. Sockets large. The median ridge merges near the mid-length with a high subperipheral rim bordering the lophophore platform.

Discussion. This species differs from Kajnaria derupta in the twice as large shell size and the well defined concentric rugellae in the posterior half of the valves.

\section{Genus $\boldsymbol{M A B E} \boldsymbol{L} \boldsymbol{L A}$ Klenina, 1984}

TYPE SPECIES. Leptellina (Mabella) semiovalis Klenina in Klenina et al. (1984), from the Taldyboy Formation, Dulankara Regional Stage (Upper Caradoc), Chingiz Range, Kazakhstan.

\section{PLATE 4}

Figs 1-5 Acculina kulanketpesica sp. nov. 1, Sample 1041a, Burultas Valley, BC 57413, dorsal interior, $\times 2.2$, Sample 8137, Anderkenyn-Akchoku section, BC 57417, latex cast of dorsal interior, $\times 3.3$, Sample 100, Anderkenyn-Akchoku section, BC 57414, dorsal exterior view of conjoined valves, $\times$ 2. 4, Sample 1018, area 7 km SW of Karpkuduk well, Kotnak Mountains, ventral internal mould, $\times 3.5$, Sample 85258, east of Uzunbulak River, BC 56491 , ventral internal mould, $\times 2$.

Fig. 6 Glyptambonites sp., Sample 628 (=K-107/70), west side of Kujandysai, BC 56510, ventral exterior, $\times 3$.

Figs 7, 8 Acculina sp. Sample 2538, Akchoku Mountain, Kujandysai section. 7, BC 56502, latex cast of dorsal interior, × 2. 8, BC 56501, ventral internal mould, $\times 1.5$.

Figs 9-25 Dulankarella larga sp. nov. 9, 10, 16, Sample 8231-40, Buldukbai-Akchoku section, west side of Kopalysai; 9, 10, BC 57421, holotype, dorsal interior, $\times 2.7$; cardinal process and socket plates, $\times 5$; 16, BC 57423, ventral internal mould, $\times 2.11-13,19-21,24,25$, Sample 1041a, Burultas Valley; 11-13, conjoined valves, lateral, ventral and dorsal views, $\times 2$; 19-21, BC 57425, conjoined valves, ventral, dorsal and lateral views, $\times 2 ; 24$, Sample 1041a, BC 56512, conjoined valves, posterior view showing interareas, $\times 6 ; 25$, BC 56967, dorsal view of conjoined valves, $\times 2$. 14, 15, 17, 18, 22, 23, Sample 100, Anderkenyn-Akchoku section; 14, BC 56514, incomplete dorsal valve interior, $\times 3$; 15, BC 57422, ventral internal mould, $\times 2$; 17, 18, BC 57424, conjoined valves, ventral and dorsal views, $\times 1.5 ; \mathbf{2 2}, \mathbf{2 3}$, BC 57426, ventral valve exterior, anterior and ventral views, $\times 2$. 


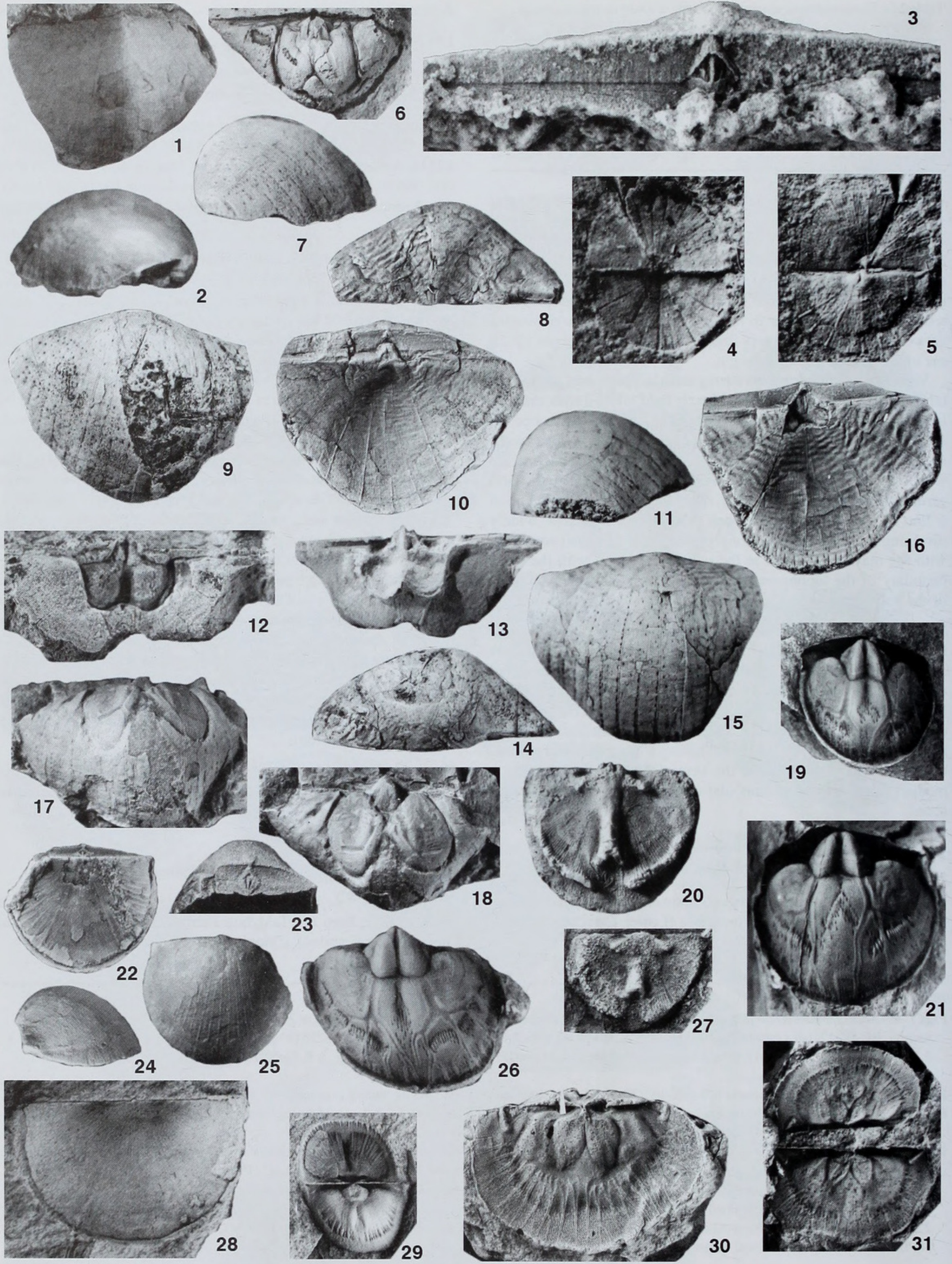


SPECIES INCLUDED. Leptellina (Mabella) semiovalis Klenina, in Klenina et al. 1984: 69, pl. 5, figs. 1, 3, 4; pl. 9, figs 4, 7 (=Leptellina (Mabella) obtusa Klenina, in Klenina et al. 1984: 71, pl. 5, figs 5, 6; pl. 6, fig. 2; =Leptellina (Mabella) incurvata Klenina, in Klenina et al. 1984: 72, pl. 5,fig. 2), Upper Caradoc, beds tb ${ }_{\text {II-V }}$ of Taldyboi Formation, Chingiz Range, Kazakhstan; Leptellina? conferta Popov, 1985: 56, pl. 2, figs 1-6, Lower Caradoc, Anderken Formation, ChuIli Range; Leptelloidea multicostata Rukavishnikova, 1956: 132; Wiradjuriella halis Percival, 1991: 138, fig. 12A-Z, Aa-Al, Upper Caradoc, New South Wales, Australia; Leptellina sp., Percival, 1979b, Ordovician, Goonumbla Volcanics, New South Wales, Australia.

DisCUSSION. Mabella differs from Leptellina in the distinctive median septum which enlarges anteriorly, and is sometimes bifurcating and tubular. However, Wiradjuriella, from the Caradoc of Australia (Percival 1991), has this same structure as Mabella and can be considered congeneric with it (Cocks \& Rong 2000).

\section{Mabella conferta (Popov, 1985)}

Pl. 5, figs 19-29

1985 Leptellina? conferta Popov: 56, pl. 2, figs 1-6, text-figs 1, 2. 1991 Wiradjuriella conferta (Popov) Percival: 140.

HoLOTYPE. CNIGR 17/11989, ventral internal mould from the Anderken Formation, Sample 100b, Anderkenyn-Akchoku section.

MATERIAL. 35 pairs of conjoined valves, 183 ventral and 66 dorsal valves from Samples 100, 100b, 843, 8128a, 8128b, 8137 (BC 56982-84), Anderkenyn-Akchoku section; Sample 7613, Kujandysai section; Samples 110, 8229, 8230 (BC 57440), 8257, BuldukbaiAkchoku; Sample 8228 (BC 57441, 43-46), east side of Kopalysai River; Samples 818a (BC 57442), 1041a (BC 56978-81), Burultas Valley; Samples 1018, 1018a, 7 km south-west of Karpkuduk well, Kotnak Mountains.

DESCRIPTION. Shell concavoconvex, transverse, semioval in outline, length about three-quarters of the width, with maximum width at the hinge line. Anterior commissure rectimarginate. Ventral valve strongly convex in transverse and lateral profiles with the maximum thickness slightly posterior to mid-length. Planar strongly apsacline interarea and small, convex pseudodeltidium. Dorsal valve gently concave to almost flat, with a planar, anacline interarea and disjunct chilidial plates. Radial ornament very fine, unequally parvicostellate, with up to five accentuated parvicostellae per $3 \mathrm{~mm}$ along the anterior margin of mature specimens.

Ventral interior with strong teeth lacking dental plates. Cordate muscle field with short, ridge-like adductor scars completely separating strongly impressed diductor scars. Strong, slightly divergent, saccate mantle canals. Dorsal interior with low, trifid cardinal process facing posteriorly, short socket ridges subparallel to the hinge line.
Lophophore platform about $90 \%$ valve length and $87 \%$ as wide as maximum valve width, bordered by a high, ridge-like rim divided medially. High median septum about three-quarters as long as the valve, not joined anteriorly with the subperipheral rim.

DISCUSSION. This species was originally assigned to Leptellina and later referred by Percival (1991) to Wiradjuriella. Percival also listed and discussed the differences between the various species of the genus, which is so far known only from Australia and Kazakhstan.

\section{Genus SHLYGINIA Nikitin \& Popov, 1983}

TYPE SPECIES. Shlyginia declivis Nikitin \& Popov, 1983, from the Andriushino Formation, Tselnograd Regional Stage (LlandeiloLower Caradoc), north-central Kazakhstan.

Discussion. The affinities of Shlyginia and its differences from Dulankarella were discussed by Nikitin \& Popov (1996).

Table 12 Measurements of complete shells of Shlyginia fragilis (Rukavishnikova) Sample 8228 and 8257 from Kopalysai section.

\begin{tabular}{lccccc}
\hline & Lv & W & T & L/W & T/L \\
\hline $\mathrm{N}$ & 16 & 16 & 16 & 16 & 16 \\
$\mathrm{X}$ & 10.4 & 16.3 & 4.2 & $64.0 \%$ & $40.4 \%$ \\
$\mathrm{~S}$ & 1.04 & 1.34 & 0.54 & 6.2 & 4.5 \\
MIN & 8.5 & 13.6 & 2.9 & $50.0 \%$ & $31.2 \%$ \\
MAX & 12.2 & 19 & 5.1 & $72.1 \%$ & $51.8 \%$ \\
\hline
\end{tabular}

Table 13 Measurements of ventral valves of Shlyginia fragilis (Rukavishnikova) Sample 8228 from Kopalysai section.

\begin{tabular}{lccllccc}
\hline & Lv & W & Ml & Mw & Lv/W & M//L & Ml/Mw \\
\hline $\mathrm{N}$ & 6 & 6 & 6 & 6 & 6 & 6 & 6 \\
$\mathrm{X}$ & 9.4 & 12.8 & 3.6 & 4.3 & $75.2 \%$ & $37.6 \%$ & $83.5 \%$ \\
$\mathrm{~S}$ & 2.47 & 3.61 & 1.13 & 1.05 & 11.2 & 4.5 & 16.3 \\
$\mathrm{MIN}$ & 5.3 & 5.8 & 1.8 & 2.6 & $60.0 \%$ & $30.5 \%$ & $67.9 \%$ \\
$\mathrm{MAX}$ & 12.8 & 15.5 & 5.3 & 5.6 & $91.4 \%$ & $41.4 \%$ & $110.4 \%$ \\
\hline
\end{tabular}

Table 14 Measurements of dorsal valves of Shlyginia fragilis (Rukavishnikova) Sample 8228 from Kopalysai section and sample 8229 from Buldukbai-Akchoku.

\begin{tabular}{lccllllll}
\hline & Ld & W & Sl & BB1 & BBw & Ld/W & Sl/L & BBw/W \\
\hline $\mathrm{N}$ & 6 & 6 & 3 & 6 & 6 & 6 & 3 & 6 \\
$\mathrm{X}$ & 8.1 & 12.1 & 5.5 & 1.2 & 3.8 & $67.7 \%$ & $79.2 \%$ & $31.7 \%$ \\
$\mathrm{~S}$ & 1.87 & 2.55 & 1.25 & 0.42 & 0.93 & 13.2 & 8.6 & 8.5 \\
$\mathrm{MIN}$ & 6.2 & 7.8 & 4.3 & 0.6 & 2.8 & $49.7 \%$ & $69.4 \%$ & $23.6 \%$ \\
MAX & 10.8 & 14.8 & 6.8 & 1.8 & 5.0 & $82.1 \%$ & $84.4 \%$ & $43.6 \%$ \\
\hline
\end{tabular}

\section{PLATE 5}

Figs 1-3 Dulankarella larga sp. nov. 1, 2, Sample 100, Anderkenyn-Akchoku, BC 57427, ventral exterior and lateral views, $\times 2.3$, Sample 1041 a, Burultas Valley, BC 56513, interareas of conjoined valves, $\times 8$.

Figs 4, 5 Chonetoidea sp. Sample 8255, Anderkenyn-Akchoku section, BC 56537, external and internal moulds of conjoined valves, $\times 8$.

Figs 6-18 Kajnaria rugosa sp. nov. 6, unnamed Lower Caradoc formation, about $4 \mathrm{~km}$ south-west of Lake Alakul, Sample 816, BC 57438, ventral internal mould, $\times 1.5 .7-11,14-16$, Sample 100, Anderkenyn-Akchoku; 7-10, BC 57436, conjoined valves, lateral, posterior, ventral and dorsal views, $\times 2$; 11, 1416, BC 57437, conjoined valves, lateral, posterior, ventral and dorsal views, $\times 2.12,13,17,18$, Sample 628, west side of Kujandysai River; 12, 13, BC 56551 , latex cast and dorsal internal mould, holotype, $\times 2 ; 17,18$, BC 57439, ventral internal mould, oblique posterior and oblique anterior views, $\times 2$.

Figs 19-29 Mabella conferta (Popov). 19, 21, 26, 28, 29, Sample 8228, east side of Kopalysai; 19, BC 57445, ventral internal mould, $\times 3 ; 21$, BC 57443, ventral internal mould, $\times 4 ; \mathbf{2 6}$, BC 57444, ventral internal mould, $\times 4 ; \mathbf{2 8}$, BC 57446, dorsal exterior, $\times 4$; 29, BC 57441, internal mould of conjoined valves of juvenile specimen, $\times 4$. 20, Sample 8230, Buldukbai-Akchoku section, west side of Kopalysai, BC 57440, latex cast of dorsal interior, $\times 3.22-$ 25, Sample 818a, Burultas Valley, BC 57442, conjoined valves, dorsal, posterior, lateral and ventral views, $\times 4$. 27, Sample 7613, Akchoku Mountain, Kujandysai section, CNIGR 20/11989, latex cast of dorsal interior of juvenile, $\times 3$.

Figs 30, 31 Tesikella necopina (Popov, 1980), Kopalysai, Rukavishnikova. 30, Sample 34, BC 56881, ventral internal mould, $\times 2$. 31, Sample 818a, Burultas Valley, BC $57435, \times 2.5$. 
Shlyginia fragilis (Rukavishnikova, 1956) Pl. 6, figs 11-25

1956 Dulankarella fragilis Rukavishnikova: 136, pl. 2, figs 1623.

1996 Shlyginia fragilis (Rukavishnikova) Nikitin \& Popov: 7.

HoLOTYPE. IGNA 28/1369, conjoined valves; Anderken Formation, east side of Kopalysai River.

MATERIAL. Eight pairs of conjoined valves, 57 ventral and 53 dorsal valves from Samples 100b (BC 56989), 620 (BC 56991-99), 843, 8128a, 8128b, 8135, 8137 (BC 57450), Anderkenyn-Akchoku section; Samples 628, 7613, 8258, Kujandysai section; Samples 110, 8230 (BC 57453), 8257, Buldukbai-Akchoku; Sample 8228 (BC 12881-88, 57447, 48, 52), east side of Kopalysai River; Samples 390, 818 (BC 57451), 1041a, Burultas Valley; Sample 1018, area 7 km south-west from Karpkuduk well, Kotnak Mountains, south Betpak-Dala.

DESCRIPTION. Shell concavoconvex, transverse, semielliptical in outline, length about two-thirds of the width, with maximum width slightly anterior to hinge line or at the hinge line, and $40 \%$ as thick as long. Cardinal extremities acute to slightly rounded. Anterior commissure rectimarginate. Ventral valve moderately convex in transverse profile with maximum thickness at about one-third of valve length. Interarea low, planar, apsacline with small triangular delthyrium, covered apically by the minute pseudodeltidium. Dorsal valve moderately convex, slightly geniculate anteriorly with low, planar, hypercline interarea and notothyrium covered laterally by disjunct chilidial plates. Radial ornament finely parvicostellate with 8-11 parvicostellae per $\mathrm{mm}$ at the anterior margin and 4-8 parvicostellae between the accentuated costellae which originate in the umbonal area, near the mid-valve and anterior to mid-valve in full grown specimens.

Ventral valve interior with small teeth lacking dental plates. Muscle field flabellate, on average $80 \%$ as long as wide and $40 \%$ as long as the valve. Diductor scars large, suboval, deeply impressed and completely enclosing small lanceolate adductor scars bisected by a fine median ridge. Ventral mantle canals saccate with short diverging vascula media. Dorsal interior with a trifid cardinal process widely diverging, low and short socket ridges and strong median ridge joined anteriorly with the peripheral rim. Dorsal adductor field large, subquadrate.

Discussion. This species differs from the type species Shlyginia declivis Nikitin \& Popov (1983: 238, pl. 3, figs 1-5) in its larger size and moderately concave lateral profile of the dorsal valve, which is also weakly geniculate anteriorly.
Subfamily PALAEOSTROPHOMENINAE Cocks \& Rong, 1989 Genus GLYPTAMBONITES Cooper, 1956

TYPE SPECIES. Glyptambonites musculosus Cooper, 1956, from the Oranda Formation (Caradoc) of Virginia, U.S.A.

\section{Glyptambonites sp. \\ Pl. 4 , fig. 6}

MATERIAL. Three ventral valves, from Sample 628 (BC 56510), Kujandysai, Sample 100, Anderkenyn-Akchoku section.

Discussion. Glyptambonites is a rare genus in the Anderken Formation and also uncommon in the overlying Dulankara Formation of the Chu-Ili Range. Its internal features are known from specimens from the latter, but not from the Anderken Formation. The exterior of our material appears similar to Glyptambonites glyptus Cooper, 1956 from the Llandeilo to early Caradoc of Virginia and Alabama.

Genus TESIKELLA gen. nov.

ETymology. After the River Tesik.

TYPE SPECIES. Palaeostrophomena necopina Popov, 1980, from the Anderken Formation, Chu-Ili Range.

DIAGNOSIS. Shell profile resupinate, ventral valve with low interarea; chilidial plates disjunct; radial ornament unequally parvicostellate; ventral interior with double teeth lacking dental plates; ventral muscle field enclosed by bilobed bounding ridges: adductor scars short; ventral subperipheral rim variably developed; dorsal interior with strong median septum coalescing anteriorly with platform.

Discussion. The subfamily Palaeostrophomeninae has the genera Palaeostrophomena, Apatomorpha, Glyptambonites, Ishimia, Lepidomena, Titanambonites and Toquimia definitely attributed to it, and Goniotrema is possibly a member (Cocks \& Rong 2000). Of these, all are of normal convexity apart from Palaeostrophomena which is generally resupinate and Toquimia, in which resupination develops anteriorly in larger specimens. Tesikella is also resupinate and in external features resembles Palaeostrophomena apart from the irregular rugae, which are variable in the latter. However, internally Tesikella has a dorsal platform which is absent in Palaeostrophomena, and also has a variably developed subperipheral rim in the ventral valve which in some specimens is fully developed but in others consists only of semi-continuous papillae. The ventral muscle field is enclosed by bilobed bounding ridges, which are not present in other members of the subfamily, but are developed in other Leptellinidae.

\section{PLATE 6}

Figs 1-6 Tesikella necopina (Popov, 1980), Sample 8129, Anderkenyn-Akchoku section. 1, BC 57433, ventral internal mould, $\times 2.2$, BC 57434, ventral exterior, $\times 2$. 3, 4, BC 57604, latex cast, $\times 3$, and dorsal internal mould, $\times 2.5,6$, BC 57432, latex cast, $\times 3$, and ventral internal mould, $\times 2$.

Figs 7-10 Sowerbyella (Sowerbyella) rukavishnikovae Popov. 7, Sample 100b, Anderkenyn-Akchoku section, CNIGR 41/11522, latex cast of dorsal exterior, $\times 5$. 8, Sample 110, Buldukbai-Akchoku section, BC 57801, ventral internal mould, $\times 4.9$, Sample 1018a, 7 km southwest of Karpkuduk well, Kotnak Mountains, south Betpak-Dala, CNIGR 44/11522, dorsal interior, $\times 2.5$. 10, Sample 100b, CNIGR 38/11989, dorsal interior, $\times 2.5$.

Figs 11-25 Shlyginia fragilis (Rukavishnikova). 11, 12, 17-19, 21, 23, 24, Sample 8228, east side of Kopalysai; 11, BC 57448, ventral internal mould, $\times$ 2; 12, BC 12882, ventral internal mould, $\times 3 ; \mathbf{1 7 - 1 9}$, BC 57447, ventral, dorsal and lateral views of conjoined valves, $\times 2 ; \mathbf{2 1}, \mathbf{2 3}, \mathbf{2 4}, \mathrm{BC} 57452$, conjoined valves, lateral, dorsal and ventral views, $\times 2$. 13-16. Sample 818 , Burultas Valley, BC 57451, conjoined valves, ventral, dorsal and lateral views, $\times 4$; posterior view of interareas, $\times 6.20$, Sample 8230, BC 57453, dorsal internal mould, $\times 3.22$, Sample 8137, Anderkenyn-Akchoku section, BC 57450 , ventral internal mould, $\times 3.25$, Sample 620, Anderkenyn-Akchoku section, BC 57449, ventral internal mould, $\times 3$.

Figs 26-33 Sortanella aff. quinquecostata Nikitin \& Popov. 26-30, Sample 2538, Akchoku Mountain, Kujandysai section; 26, BC 57488, ventral internal mould, $\times 2$; 27-29, BC56771, conjoined valves, dorsal, ventral and lateral views, $\times 4$; 30, BC 57460, ventral internal mould, $\times 4$. 31, Sample 626, Anderkenyn-Akchoku section, BC 57458, dorsal exterior, $\times 2$. 32, 33, Sample 100, Anderkenyn-Akchoku section, BC 57459, conjoined valves, dorsal and ventral views, $\times 2$. 


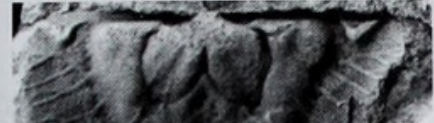 (1) of 1}
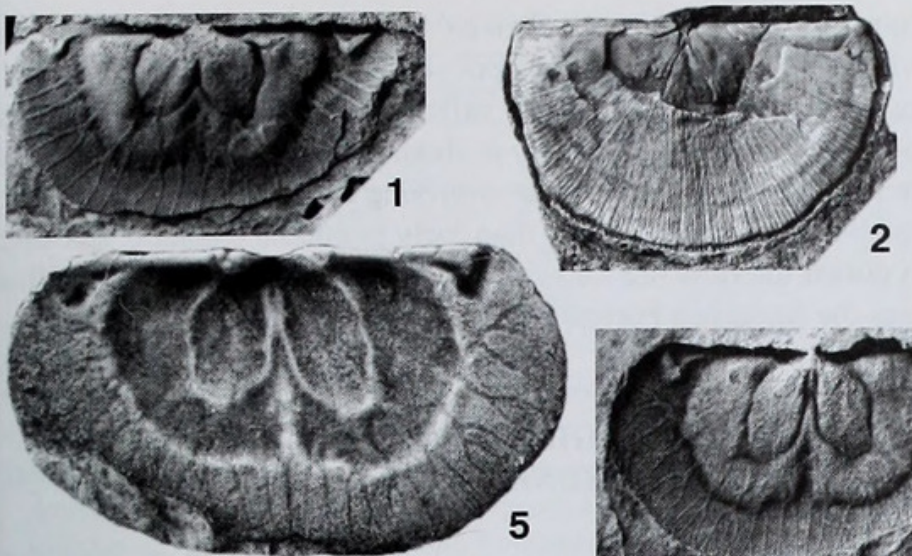

5

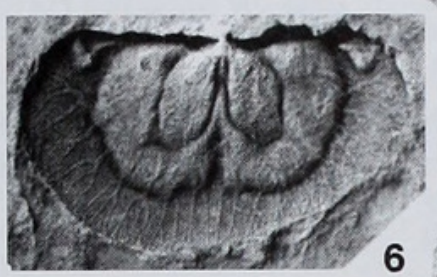

6

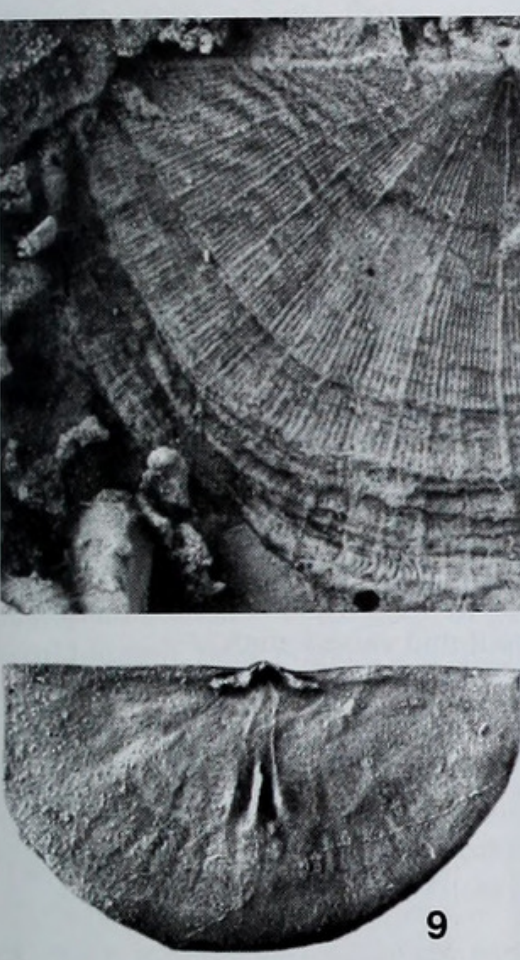

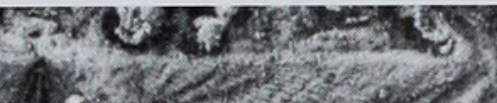
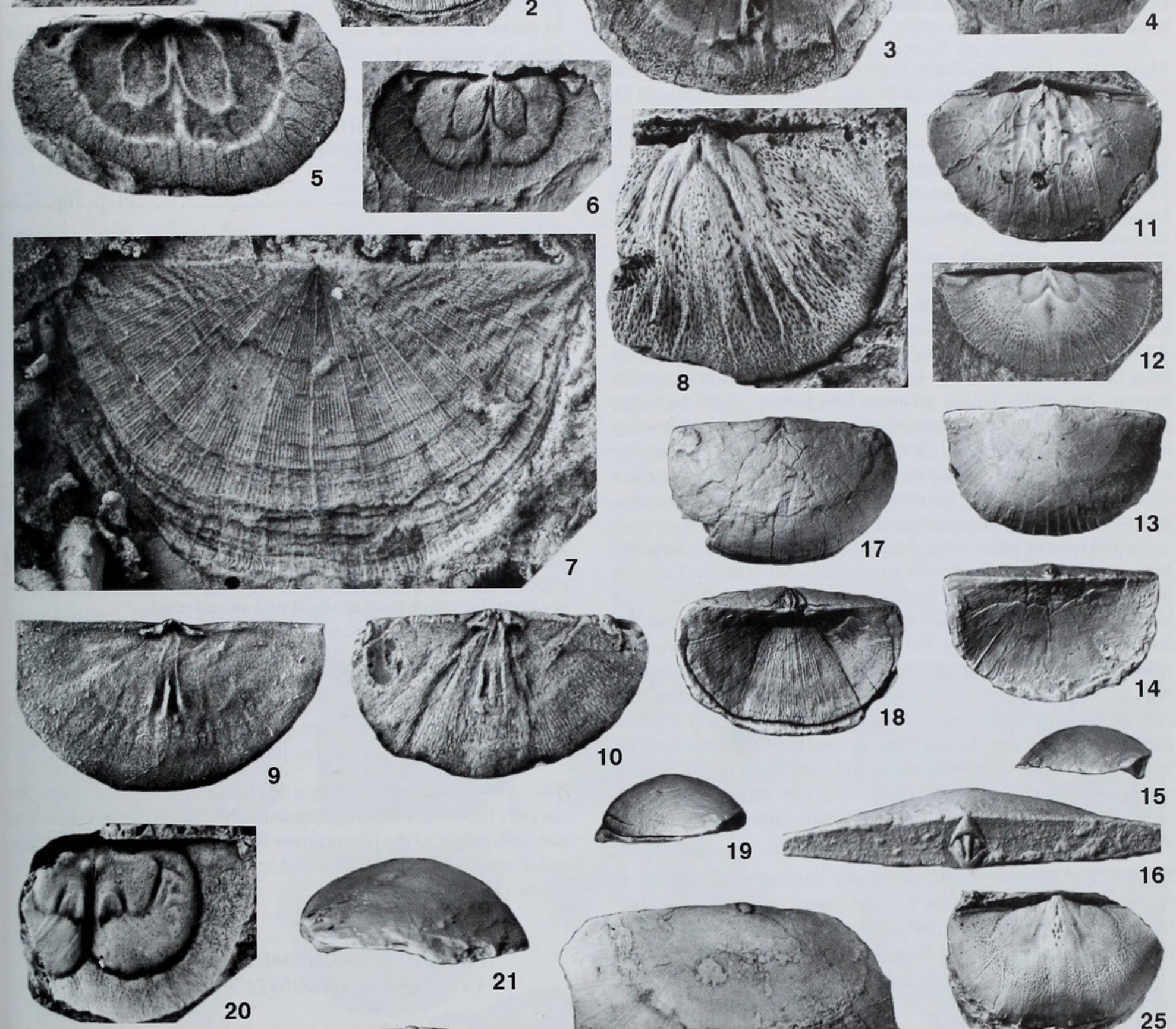

19
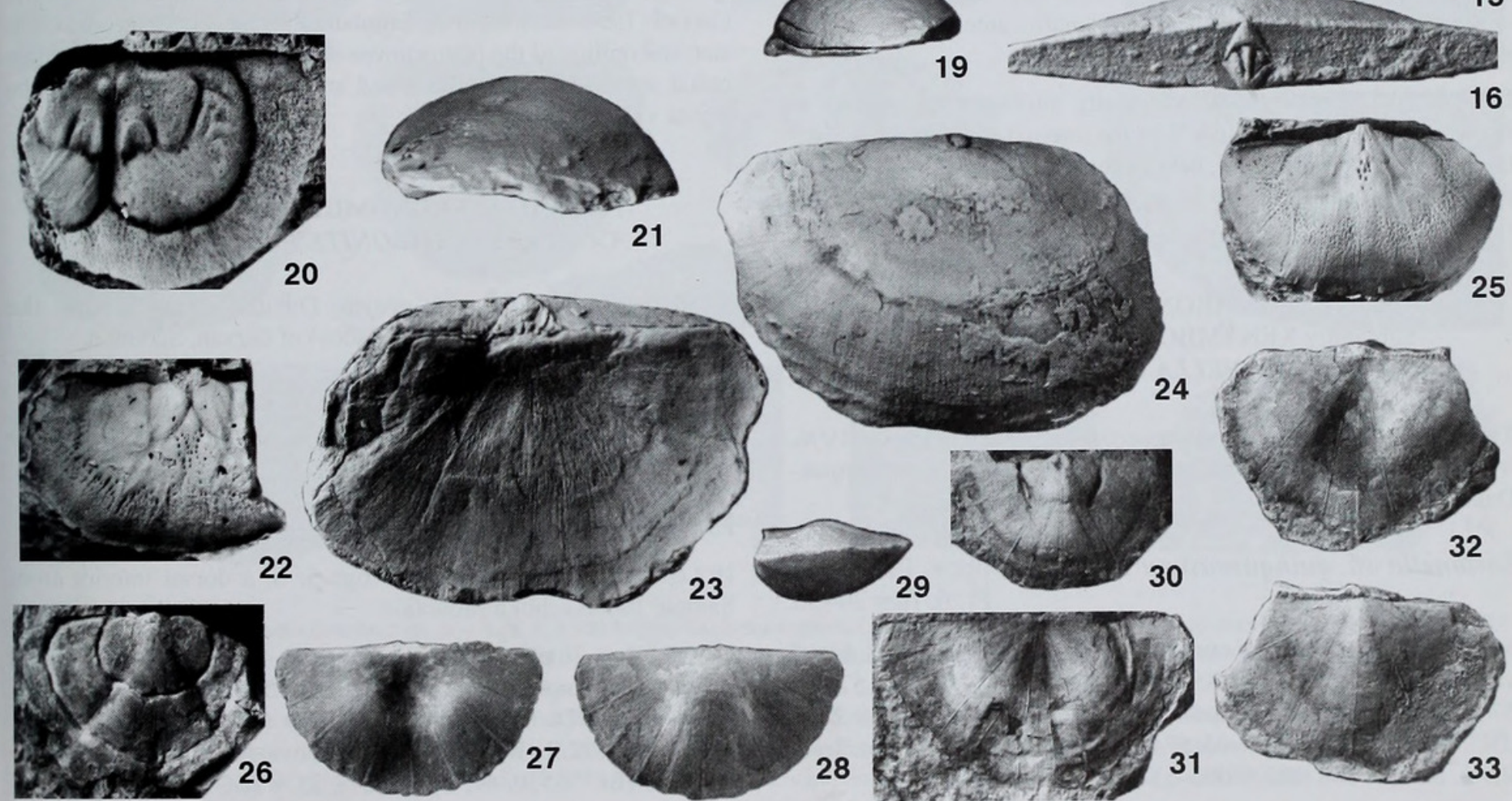

23
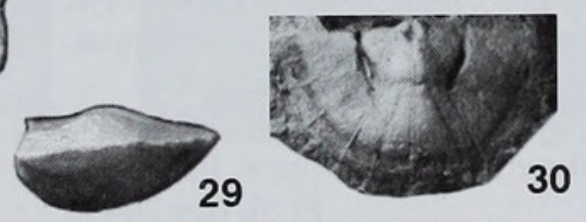

30

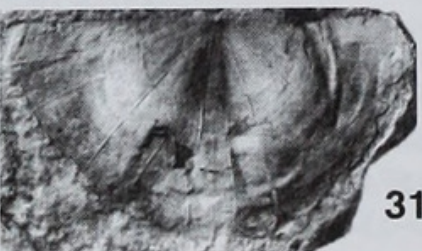

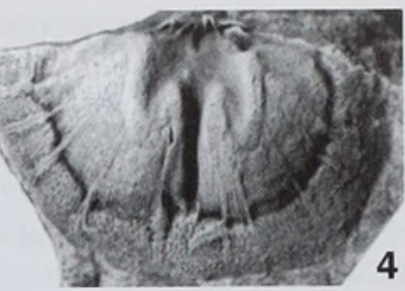

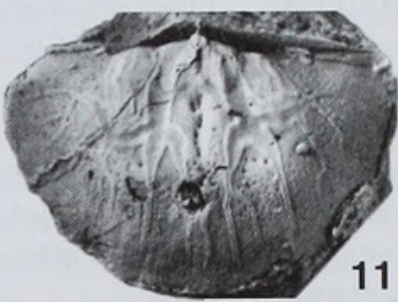

\section{2}

\section{3}
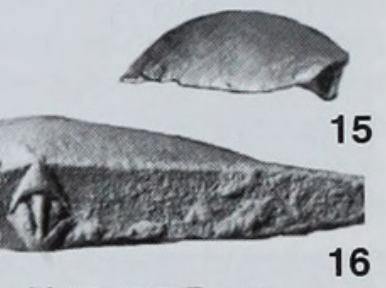
Tesikella necopina (Popov, 1980)

Pl. 5, figs 30 , 31, Pl. 6, figs $1-6$

1980 Palaeostrophomena necopina Popov: 145, pl. 1, figs 8-11.

HoLOTYPE. CNIGR 15/11523 ( $\mathrm{L}=11.4, \mathrm{~W}=16.8$ ), dorsal internal mould, Anderken Formation, east side of Kopalysai, Sample 127/K1970.

MATERIAL. Five pairs of conjoined valves, 60 ventral and 43 dorsal valves from Samples 8128, 8129 (BC 57432-34, 57604), 8138, Anderkenyn-Akchoku section; Sample 7613, Kujandysai section; Sample 127/K-1970 and Rukavishnikova (1956) Sample 34 (BC 56881), east side of Kopalysai; Sample 818a (BC 57435), Burultas Valley; Sample 1024b, east side of Karatal near Sorbulak well; Samples 1018, 1018a, area 7 km south-west of Karpkuduk well, Kotnak Mountains

DESCRIPTION. Shell profile resupinate, transversely subrectangular outline, about $55-60 \%$ as long as wide with maximum width at the hinge line. Cardinal extremities slightly acute to near right angled. Anterior commissure rectimarginate, broadly rounded. Ventral valve with lateral profile slightly convex in the umbonal area, gently concave anteriorly. Ventral interarea low, planar, catacline with a well developed, narrow pseudodeltidium. Dorsal valve with moderately convex lateral profile, flattened posteriorly with low anacline interarea and separate chilidial plates. Radial ornament parvicostellate with $10-12$ parvicostellae per $\mathrm{mm}$ in mature specimens and accentuated costellae of two-three generations.

Ventral interior with strong, double teeth lacking dental plates and large divided musle field with strong diductor scars and muscle bounding ridges extending anteriorly to the mid-valve. Adductor scars small, strip-like, divided by a fine median ridge, about half the length of the diductor scars. Subperipheral rim variably developed, posterior to which is a weak median ridge. Mantle canals saccate with very short vascula media branching just beneath the anterior margin of the diductor scars. Dorsal interior with trifid cardinal process on a low notothyrial platform and low, widely diverging socket ridges. Median septum strong and narrow, about $75 \%$ as long as the valve and joined anteriorly to a low subperipheral rim. Adductor scars radially arranged with smaller anterior pair extending anteriorly to mid-valve.

Discussion. Popov (1980) originally attributed the species to Palaeostrophomena, but since then the internal characteristics, particularly of the ventral valve, have become known, and it is clear that this species cannot properly be attributed to that genus.

Family XENAMBONITIDAE Cooper, 1956 Subfamily XENAMBONITINAE Cooper, 1956 Genus SORTANELLA Nikitin \& Popov, 1996

TYPE SPECIES. Sortanella quinquecostata Nikitin \& Popov, 1996, from the Dulankara Regional Stage (Upper Caradoc), north BetpakDala, Kazakhstan.

Sortanella aff. quinquecostata Nikitin \& Popov, 1996 Pl. 6, figs 26-33

MATERIAL. Ten pairs of conjoined valves, 7 ventral and 8 dorsal valves from Samples 100 (=K98/1970) (BC 57459), 626 (BC 57000, 57006-9, 57458), Anderkenyn-Akchoku section; Samples 628, 2538 (BC 56771, 56810, 57010-03, 57460, 88), Kujandysai section; Tesik River, Sample 948 (BC 57002-5).
DisCUSSION. These specimens closely resemble Sortanella quinquecostata Nikitin \& Popov (1996: 9) in radial ornament, posteriorly subcarinate ventral valve and gently uniplicate anterior commissure. The type locality is about $400 \mathrm{~km}$ to the north-west of our localities, and occurs in the overlying Dulankara Regional Stage which is late Caradoc rather than early to middle Caradoc. Because no dorsal interiors are known, the species cannot yet be identified from the Anderken Formation with certainty.

\section{Subfamily AEGIROMENINAE Havlíek, 1961 Genus CHONETOIDEA Jones, 1928}

\section{Chonetoidea sp.}

Pl. 5, figs 4,5

TYPE SPECIES. Plectambonites papillosa Reed, 1905, from the Slade and Redhill Mudstone Formation (Middle Ashgill), Pembrokeshire, Wales.

MATERIAL. One internal and one external mould of a pair of conjoined valves, BC 56537 ( $\mathrm{L}=3.2, \mathrm{~W}=5.1)$ from Sample 8255, Anderkenyn-Akchoku section.

DESCRIPTION. Shell planoconvex, transverse, semielliptical in outline with maximum width at the hinge line. Cardinal extremities acute. Anterior commissure rectimarginate. Ventral valve gently convex in lateral profile with maximum thickness slightly anterior to the apex. Interarea low, planar, anacline with minute apical pseudodeltidium. Dorsal valve flat with a low, anacline interarea. Chilidial plates separate. Radial ornament finely and unequally parvicostellate with five accentuated primary ribs and four secondary costellae originating at about mid valve length.

Ventral interior with small, bilobate muscle field bisected posteriorly by low median ridge. Dorsal interior with simple undercut cardinal process joined to minute socket ridges subparallel to the hinge line. Median ridge originating anterior to the deep alveolus and extending to mid-valve. Six septulae lateral to the anterior part of the median ridge near the mid-valve.

DISCUSSION. These specimens resemble Chonetoidea virginica Cooper (1956: 805), from the Edinburg Formation of Virginia, in the size and outline of the planoconvex shell, unequally parvicostellate radial ornament, and number and arrangement of septulae in the dorsal valve.

Family HESPERONOMIIDAE Cooper, 1956 Genus ANOPTAMBONITES Williams, 1962

TYPE SPECIES. Leptaena grayae Davidson, 1883, from the Craighead Limestone (Upper Caradoc) of Girvan, Scotland.

Anoptambonites convexus sp. nov.

Pl. 7, figs 5-26; Figs 12.1-12.6

1986 Anoptambonites sp.; Kolobova \& Popov, pl. 1, figs 7, 8.

ETYMOLOGY. After convexus, Latin - convex.

HolotyPe. BC 57462, Pl. 7, figs 5, 6, a dorsal interior from Sample 100, Akchoku Mountain.

MATERIAL. 36 pairs of conjoined valves, 21 ventral and 14 dorsal valves from Samples $100(=$ K98/1970) (BC 56540, 57014-32, 57462, 64, 69, 71), 626 (BC 57466, 68), 8214 (BC 57480), 8223 (BC 57063-68), 8223b (BC 57467), Anderkenyn-Akchoku section; Samples 628 (BC 56530, 42, 57043-51), 2538 (BC 56531, 57052-61, 
Table 15 Measurements of complete shells and ventral valves of Anoptambonites convexa sp. nov., Acculina-Dulankarella Association, samples 100 and 626 from Anderkenyn-Akchoku section.

\begin{tabular}{lcclcc}
\hline & Lv & W & T & Lv/W & T/Lv \\
\hline $\mathrm{N}$ & 18 & 17 & 8 & 17 & 8 \\
$\mathrm{X}$ & 12.1 & 16.5 & 6.9 & $71.6 \%$ & $47.1 \%$ \\
$\mathrm{~S}$ & 4.24 & 5.26 & 1.86 & 7.5 & 6.3 \\
MIN & 5.8 & 8.2 & 3.5 & $57.8 \%$ & $39.4 \%$ \\
MAX & 18.0 & 23.9 & 9.6 & $86.5 \%$ & $58.9 \%$ \\
\hline
\end{tabular}

Table 16 Measurements of complete shells and ventral valves of

Anoptambonites convexa sp. nov., Parastrophina-Kellerella Association, samples 2538,8217 and 8256 from Kujandysai section.

\begin{tabular}{lcclcc}
\hline & $\mathrm{Lv}$ & $\mathrm{W}$ & $\mathrm{T}$ & $\mathrm{Lv} / \mathrm{W}$ & $\mathrm{T} / \mathrm{Lv}$ \\
\hline $\mathrm{N}$ & 11 & 11 & 4 & 11 & 4 \\
$\mathrm{X}$ & 6.4 & 9.9 & 2.8 & $65.5 \%$ & $44.8 \%$ \\
$\mathrm{~S}$ & 1.13 & 2.33 & 0.57 & 7.6 & 6.1 \\
MIN & 5.2 & 6.6 & 2.0 & $57.0 \%$ & $38.5 \%$ \\
MAX & 9.0 & 15.3 & 3.2 & $79.3 \%$ & $51.6 \%$ \\
\hline
\end{tabular}

57461, 63, 65), 8217, 8256 (BC 57070-73), Kujandysai section; Samples 8230 (BC 57069), 8231-40, Buldukbai-Akchoku.

DESCRIPTION. Shell concavoconvex, transverse, semielliptical in outline, about $72 \%$ as long as wide with maximum width at hinge line and thickness $47 \%$ of valve length. Cardinal extremities slightly acute to rectangular. Anterior commissure rectimarginate. Ventral valve carinate posteriorly, strongly convex in lateral profile with the maximum thickness at the point of geniculation somewhat anterior to mid-length. Beak pointed and slightly erect posterior to the hinge line. Ventral interarea steeply apsacline to procline with mainly open delthyrium covered apically by the minute pseudodeltidium. Dorsal valve gently and unevenly concave in lateral profile, flat to midlength. A shallow sulcus originates at the umbo and fades towards the anterior margin. Dorsal interarea anacline with convex chilidium. Radial ornament finely and near equally multicostellate with 28-43 primary ribs originating near the umbo and $4-6$ ribs per $\mathrm{mm}$ at the anterior margin. Concentric ornament of fine, evenly spaced fila.

Ventral valve with teeth lacking dental plates. Muscle field small, cordate, bisected by fine median ridge separating small, lanceolate adductor scars. Vascula media short, widely diverging. Dorsal interior with undercut cardinal process bearing up to 8 ridges on both sides of strong central lobe. Lophophore platform semielliptical, bordered by a high rim joined to the median septum. Dorsal adductor muscle field subrectangular, about one-third as long as the valve.

VARIABILITY. The average size of Anoptambonites convexus from the Acculina-Dulankarella Association, which typically occurs within the nodular limestone deposited on the flanks of carbonate mud mounds (Sample 100), is one and half to two times larger than the average size of the shells from the pockets in the mud mound core (Samples 2538 and 8231-40) and the overlying bedded limestone (Samples 628, 8217, 8223, 8256) in which the ParastrophinaKellereila Association characteristically occurs. However, the specimens from the Parastrophina-Kellerella Association retain a similar outline, transverse and lateral profile of the shells from the Acculina-Dulankarella Association and are also characterized by their multicostellate ornament which consists of 26 to 36 primary ribs and 4 to 6 ribs along the anterior margin of full grown specimens.

DISCUSSION. This species differs from Anoptambonites grayae (Davidson), as revised by Williams (1962: 171) from the Craighead
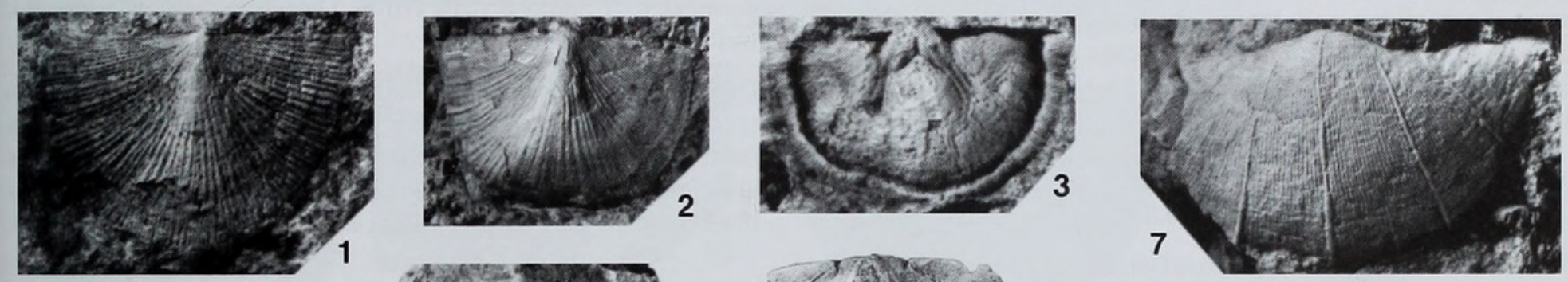
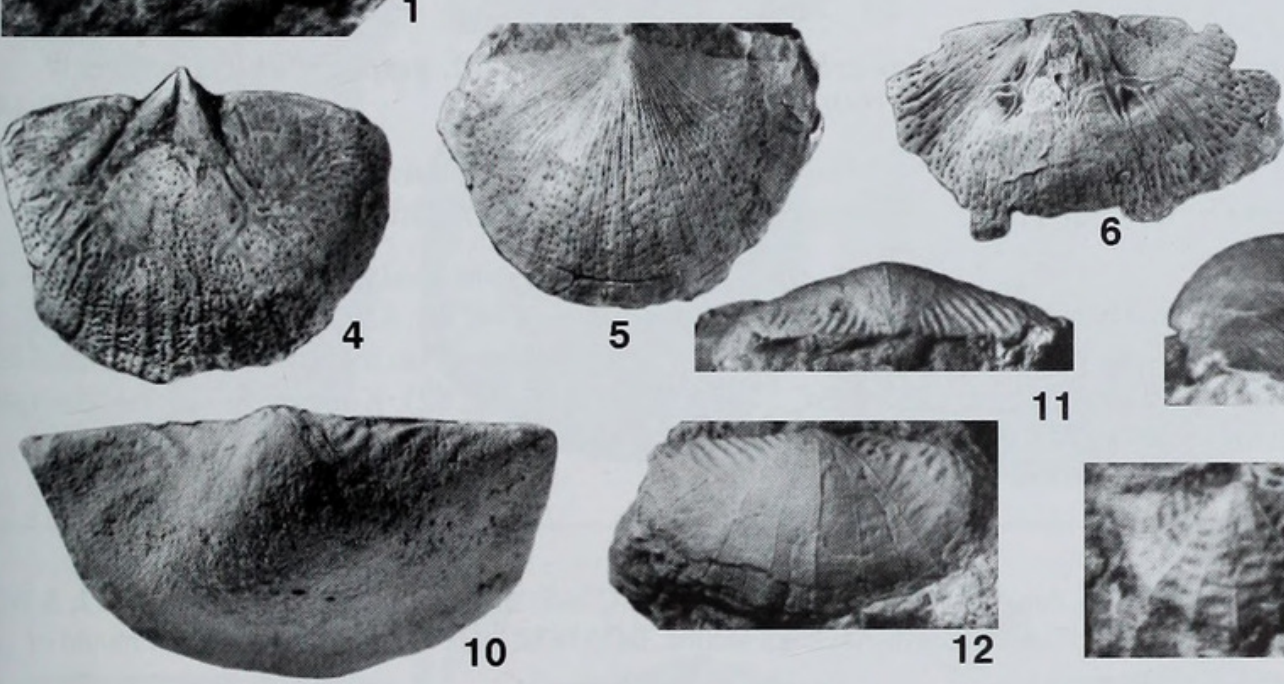

5

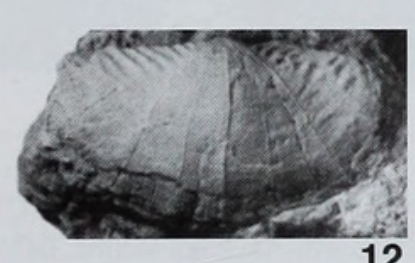

11
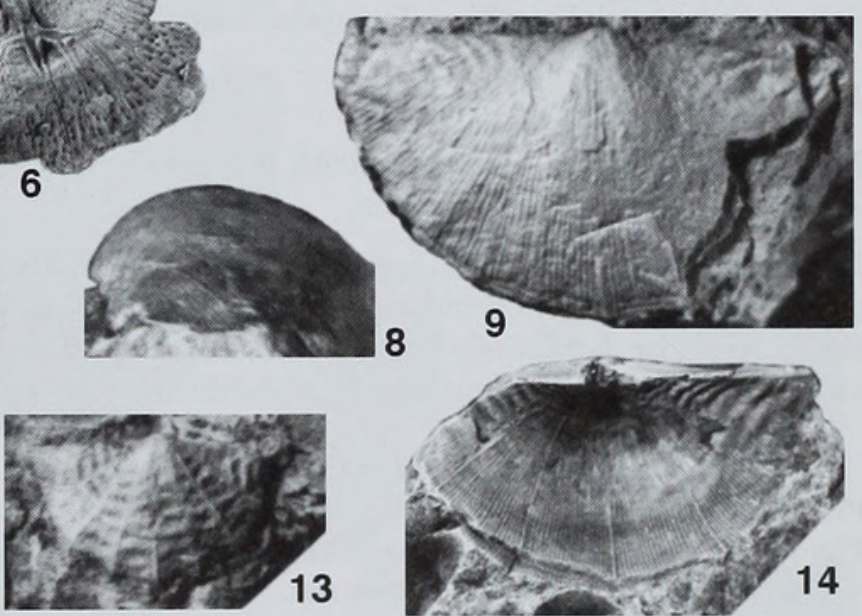

8

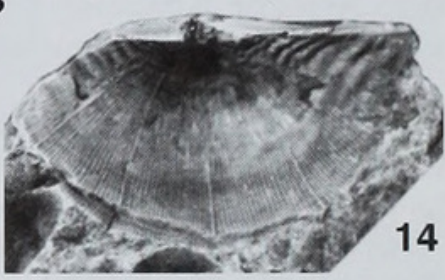

Fig. 12 1-6. Anoptambonites convexus sp. nov. 1, 4, 5, Anderkenyn-Akchoku section, 1, Sample 8223b, BC 57467, ventral exterior, $\times 3 ;$ 4, 5, Sample 100, 4, BC 57470, ventral internal mould, $\times 2$; 5, BC 57472, ventral exterior, $\times 2.3$, 6, Buldukbai section, 3, Sample 8230, BC 57069, ventral internal mould, $\times 3,6$, Sample 8231, BC 57473, ventral internal mould, $\times 1.5 .2$, Kujandysai section, Sample 8256, ventral exterior, $\times 2$.

7-14, Sowerbyella (Sowerbyella) aff. ampla (Nikitin \& Popov), 7-13, Kujandysai section, Sample 2538, 7, BC 57082, ventral exterior, $\times 3 ; \mathbf{8}, \mathbf{9}$, BC 57482 , lateral and ventral views of ventral exterior, $\times 4 ; \mathbf{1 0}$, BC 57081, ventral internal mould, $\times 3 ; \mathbf{1 1}, \mathbf{1 2}$, BC 57479, anterior and ventral views of ventral exterior, $\times 3$; 13, BC 57481, ventral exterior, $\times 3$.14, Anderkenyn-Akchoku section, Sample 8214, BC 57480, dorsal exterior, $\times 2.5$. 
Limestone (Upper Caradoc) of Girvan, in having a strongly concavoconvex lateral profile, a cardinal process with up to 8 vertical ridges on the lateral lobes, a shorter median septum and a relatively small lophophore platform extending anteriorly only to the mid-valve. Anoptambonites convexus differs from two somewhat younger Kazakh species, A. subcarinatus Nikitin \& Popov (1996:10) from the north Betpak-Dala and A. kovalevskii Popov, Nikitin \& Cocks (2000), from the Dulankara Mountains, both from the Dulankara Regional Stage (Upper Caradoc to lowermost Ashgill), in having equally multicostellate radial ornament and a weakly geniculate ventral valve profile, with the maximum height anterior to the midvalve and near the point of geniculation. It also differs from the former species in having a rectimarginate anterior commissure.

\section{Anoptambonites orientalis Popov, 1980 Pl. 7, figs 1-4, 27}

1980 Anoptambonites orientalis Popov:149; pl. 2, figs 12-17.

HolotyPE. CNIGR 30/11523, dorsal internal mould, from the Anderken Formation, Anderkenyn-Akchoku section, Sample 100b.

MATERIAL. Two pairs of conjoined valves, 14 ventral and 26 dorsal valves from Samples 100b, 8128a (BC 56533, 57476), 8128b, 8137 (BC 57478), Anderkenyn-Akchoku section; Sample 8230, Buldukbai-Akchoku section, and Sample 1018, about 7 km southwest of Karpkuduk well, Kotnak Mountains.

DisCUSSION. Detailed description of this species was provided by Popov (1980). It differs from the contemporaneous Anoptambonites convexus sp. nov. as well as from the somewhat younger $A$. subcarinatus Nikitin \& Popov, 1996 and A. kovalevskii Popov, Nikitin \& Cocks, 2000 in having a flattened shell, a carinate ventral valve with gently and evenly convex lateral profile lacking geniculation, a very weakly concave dorsal valve, and in the presence of a small but well-defined pseudodeltidium. The platform in mature specimens of $A$. orientalis reaches up to $75 \%$ of the valve length, whereas in $A$. convexus and $A$. kovalevskii it barely exceeds half the valve length.

\section{Genus KASSINELLA (KASSINELLA) Borissiak, 1956}

TYPE SPECIES. Kassinella globosa Borissiak, 1956, from the Lower Ashgill Kulunbulak Formation, Tarbagatai Range, Kazakhstan.

\section{Kassinella (Kassinella)? sp. $\quad$ Pl. 3, fig. 24}

MATERIAL. One dorsal internal mould, BC 56497, from Sample 2531, Anderkenyn-Akchoku section.

Discussion. A single dorsal valve shows the undercut cardinal process and lack of both bema and side septa characteristic of the Hesperomenidae. It possesses an evenly semicircular platform and a median septum not extending anterior of the platform. This evenly semicircular platform is unlike most species of Hesperomena, Anoptambonites, Aulie and Chaganella: within the family only Kassinella (Kassinella) has such a platform. However, without knowledge of the ventral interior and the exterior of both valves, generic assignment can only be provisional. Kassinella (Kassinella) is known from the late Caradoc and Ashgill of Kazakhstan, South China, Australia, Scotland, Bohemia and Sweden (Zhan \& Cocks 1998:36), but if the record from the Anderken Formation is confirmed then this may be its earliest occurrence.

Family SOWERBYELLIDAE Öpik, 1930 Subfamily SOWERBYELLINAE Öpik, 1930 Genus SOWERBYELLA (SOWERBYELLA) Jones, 1928

TYPE SPECIES. Leptaena sericea J. de C. Sowerby, 1839, from the Horderley Sandstone (Lower Caradoc) of Shropshire, England.

\section{Sowerbyella (Sowerbyella) rukavishnikovae Popov, 1980} Pl. 6, figs $7-10$

1980 Sowerbyella rukavishnikovae Popov: 151, pl. 2, figs 1-4. 1984 Sowerbyella rukavishnikovae Popov; Nikitin \& Popov in Klenina et al.:150, pl. 16, figs 17-22.

HolOTYPE. CNIGR 40/11523, a dorsal internal mould from the Anderken Formation, Anderkenyn-Akchoku section, Sample 100b.

MATERIAL. 70 ventral and 133 dorsal valves. Samples $100 \mathrm{~b}$ (BC 56554-5), 848, 8128a, 8128b, 8137, Anderkenyn-Akchoku section; Sample 7613, Kujandysai section; Samples 110 (BC 57801), 8229, 8230,8257 , Buldukbai-Akchoku; Sample 8228, east side of the Kopalysai River; Sample 1024b, east side of Karatal Valley, near Sorbulak well; Samples 1018, 1018a, 7 km south-west of Karpkuduk well, Kotnak Mountains.

DisCUSSION. Description, discussion and basic statistics of this species were provided by Popov (1980). Some further specimens from the Anderken Formation are illustrated here. This species is also reported from the upper Bestamak and lower Sargaldak Formations of the Chingiz Range (Nikitin \& Popov in Klenina et al. 1984).

\section{Sowerbyella (Sowerbyella) aff. ampla (Nikitin \& Popov, 1996)}

Figs $12.7-12.14$

1986 Anisopleurella sp. Kolobova \& Popov: pl. 1, fig. 6. aff.1996 Anisopleurella ampla Nikitin \& Popov: 12, figs 5K-R.

MATERIAL. 14 pairs of conjoined valves, 25 ventral and 8 dorsal valves from Samples 100 (=K98/70), 626, 2531, 8214 (BC 57480), $8215,8223 \mathrm{a}, 8223 \mathrm{~b}$, Anderkenyn-Akchoku section; Samples 628, 2538 (BC 57081, 82, 57479, 81, 82), Kujandysai section; Sample 948 (BC 57084-85), Tesik River.

\section{PLATE 7}

Figs 1-4, 27 Anoptambonites orientalis Popov. 1-3, Sample 8128a, Anderkenyn-Akchoku section; 1, BC 56533, latex cast of dorsal interior, $\times$ 4; 2, 3, BC 57476, ventral internal mould and latex cast, $\times 2.4,27$, Sample 8137, Anderkenyn-Akchoku section, BC 57478, latex cast and dorsal internal mould of immature specimen, $\times 4$.

Figs 5-26 Anoptambonites convexus sp. nov. 5, 6, 9, 10, 18, 20-22, Sample 100, Anderkenyn-Akchoku section; 5, 6, BC 57462, holotype, dorsal internal mould and latex cast, $\times 2 ; \mathbf{9}, \mathbf{1 0}$, BC 57464 , posterior view of conjoined valves showing interareas, $\times 1.5$ and $\times 5 ; \mathbf{1 8}$, BC 57469 , ventral exterior, $\times 2 ; \mathbf{2 0}$ 22, BC 57471, conjoined valves, ventral, lateral and dorsal views, $\times 2.7,8,11-16$, Sample 2538, Akchoku Mountain, Kujandysai section; 7, BC 57461, ventral internal mould, $\times 3 ; \mathbf{8}$, CNIGR 7/12361, ventral exterior, $\times 3 ; \mathbf{1 1}, \mathbf{1 2}$, BC 57465, latex cast and dorsal internal mould, $\times 3$; 13-16, BC 57463, conjoined valves, dorsal, lateral, ventral and posterior views, $\times 3.17,23-26$, Sample 626, Anderkenyn-Akchoku section; 17, BC 57466, ventral internal mould, $\times 1.5 ;$ 23-26, BC 57468, conjoined valves, dorsal, posterior, lateral and ventral views, $\times 2$. 19, Sample 628 (=K-107/70), west side of Kujandysai, BC 56542, ventral internal mould, $\times 2$. 

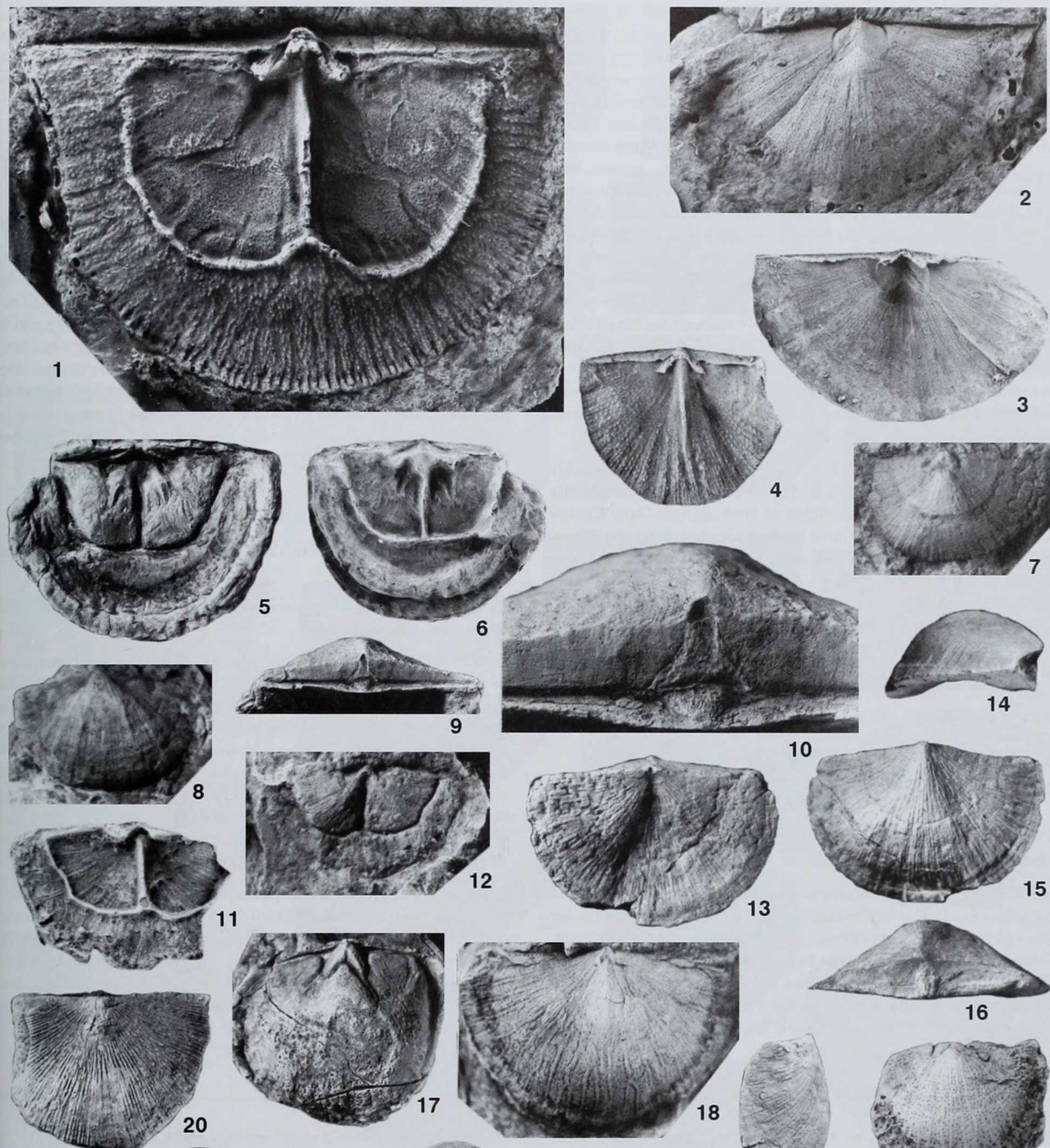

16
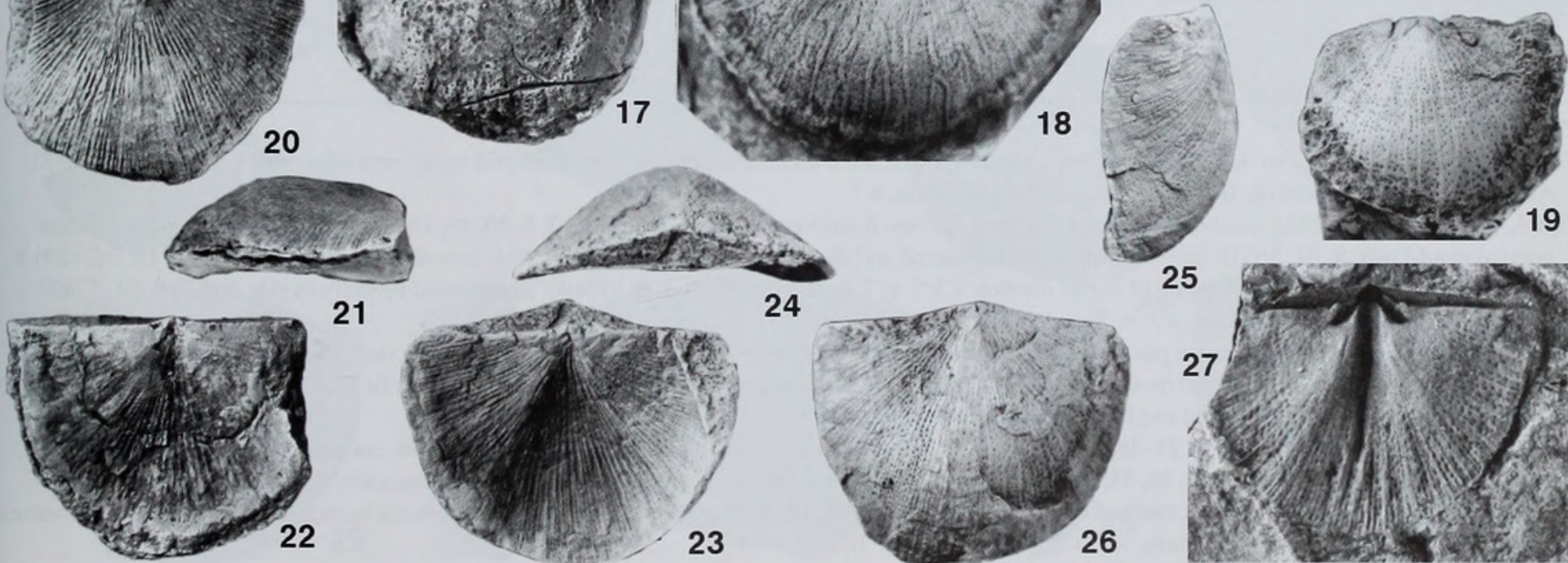

21

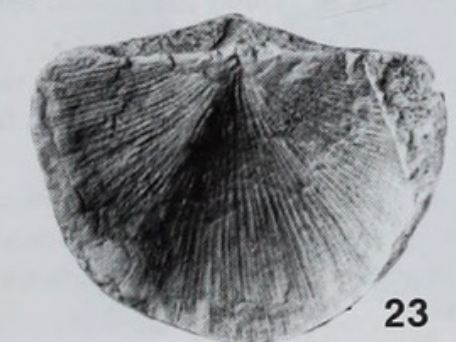

24

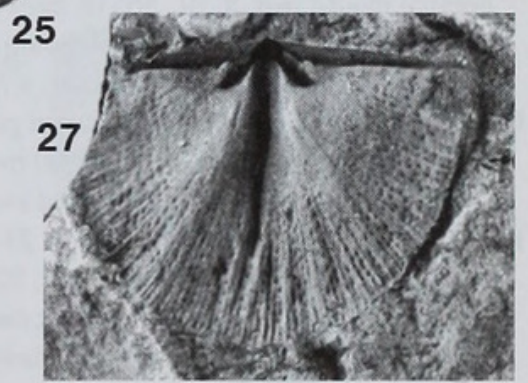


DESCRIPTION. Shell concavoconvex, transverse, semielliptical in outline, about $56 \%$ as long as wide, with maximum width at hinge line. Cardinal extremities acute and slightly alate. Anterior commissure broadly rounded and rectimarginate. Ventral valve moderately and unevenly convex in profile with the maximum thickness at about quarter valve length. Ventral interarea strongly apsacline and slightly curved in cross-section, with small triangular delthyrium covered apically by pseudodeltidium. Dorsal valve moderately concave, with hypercline interarea; notothyrium covered laterally by chilidial plates. Radial ornament unequally and finely parvicostellate with closelyspaced parvicostellae varying from 9 to 12 per mm. Five accentuated ribs originating at the umbo and four accentuated costellae inclined between them in the mid-valve. Indistinct radial plications developed sometimes along the accentuated ribs. About 6-9 strong concentric rugellae inclined below $30-40^{\circ}$ towards the hinge line.

Ventral interior with small teeth lacking dental plates and small bilobate muscle field with flabellate diductor scars completely surrounding small lanceolate adductor scars. Dorsal interior with undercut cardinal process, small curved socket ridges, bilobed bema, short median ridge and two widely divergent side septa.

Discussion. The Anderken specimens strongly resemble Anisopleurella ampla Nikitin \& Popov (1996) from the slightly younger Dulankara Regional Stage of north Betpak-Dala, Central Kazakhstan, in size and general shell shape, but differ slightly in having a finer radial ornament with 9-12 parvicostellae per $\mathrm{mm}$ instead of 7-10 in the Dulankara specimens, and an uneven ventral valve lateral profile. Anisopleurella ampla is reassigned here to Sowerbyella (Sowerbyella) mainly because it has two pairs of side septa including a closely-spaced more prominent pair. In the variable development of strong concentric ornament it is similar to the subgenus $S$. (Rugosowerbyella), but differs in having a median septum and the two pairs of side septa, and in the small, weakly impressed ventral muscle field.

\section{Genus ANISOPLEURELLA Cooper, 1956}

TYPE SPECIES. Anisopleurella tricostellata Cooper, 1956, from the Pratt Ferry Formation (Llandeilo) of Alabama, U.S.A.

DisCUSSION. The relationships of Anisopleurella and other genera are unresolved. The Ordovician genera within the subfamily are Sowerbyella, Anisopleurella, Eochonetes, Eoplectodonta, Gunningblandella and our new genera Olgambonites and Zhilgyzambonites. Eochonetes and Eoplectodonta may be interpreted as Sowerbyella with hinge lines modified to form denticles (which resulted in the subsequent loss of dental plates), and
Gunningblandella and Olgambonites are resupinate modifications of Sowerbyella, which was a very plastic stock. Anisopleurella has a much more distinctive and erect dorsal median septum and side septa than Sowerbyella, with the side septa bisecting the divided bema but not reaching to the anterior edge of it. Both genera occur in rocks of Llandeilo age, but which of the two was ancestral is not known.

\section{Anisopleurella sp.}

Pl. 8 , figs $1,2,5$

MATERIAL. One ventral and one dorsal internal mould from Samples 2531 (BC 57489), 8255 (BC 56539), Anderkenyn-Akchoku section.

Discussion. These specimens can be firmly assigned to Anisopleurella because they have the characteristic parvicostellate ornament with three accentuated ribs, a dorsal median ridge and a pair of widely diverging prominent side septa bisecting a bilobed bema. They are somewhat comparable to, and may be conspecific with, Anisopleurella yichangensis Zeng, 1987 from the early Caradoc Miaopo Formation of Hubei, South China, but the absence of wellpreserved exteriors of the Chinese species makes detailed comparison impossible.

\section{Genus OLGAMBONITES gen. nov.}

ETYMOLOGY. After the late Olga Ivanova Nikiforova, a pioneer in brachiopod studies.

TYPE SPECIES. Olgambonites insolita sp. nov. from the Anderken Formation, Chu-Ili Range.

DiAGNOSIS. Shell convexiconcave; anterior commissure rectimarginate to weakly uniplicate; ventral interarea procline to slightly apsacline with apical pseudodeltidium; dorsal interarea anacline with separate chilidial plates; radial ornament unequally parvicostellate; ventral interior with small teeth lacking dental plates and small bilobed muscle field with short adductor scars completely separating larger diductor scars; ventral mantle canals lemniscate; dorsal interior with simple undercut cardinal process joined to narrow socket ridges; fine median ridge and bilobed bema bordered by rim and crossed by up to 8 side septa.

DISCUSSION. Olgambonites possesses an undercut cardinal process, divided bema and side septa in the dorsal valve; all characteristic of the Sowerbyellidae, but it differs from most genera in the family in having a convexiconcave shell. The only other resupinate genus is Gunningblandella (Percival 1979b) from the Caradoc of Australia, but Olgambonites differs from that genus in having a dorsal median septum and numerous side septa.

\section{PLATE 8}

Figs 1, 2, 5 Anisopleurella sp. 1, 2, Sample 8255, Anderkenyn-Akchoku section, BC 56539, dorsal internal mould and latex cast, $\times 12.5$, Sample 2531, Anderkenyn-Akchoku section, BC 57489, ventral internal mould, $\times 7$.

Figs 3, 4, 6-10, 12, 13 Zhilgyzambonites extenuata gen. et sp. nov. Anderkenyn-Akchoku section. 3, 9, 10, 12, 13, Sample 8255; 3, BC 57493, ventral internal mould, $\times 6$; 9, BC 56538, latex cast of conjoined ventral and dorsal interiors, $\times 4$; 10, BC 57494, ventral internal mould, $\times 6$; 12, 13, BC 12915, holotype, latex cast and internal mould of dorsal interior, $\times 5.5 .4,7,8$, Sample $2531 ; \mathbf{4}$, BC 57490, latex cast of ventral exterior, $\times 6 ; 7,8$, BC 57492 , dorsal internal mould and latex cast, $\times 5$. 6, Sample 8215 , BC 57491, latex cast of dorsal exterior, $\times 6$.

Figs 11, 14-20 Olgambonites insolita gen. et sp. nov. Sample 8255, Anderkenyn-Akchoku section. 11, BC 56535, dorsal external mould, $\times 4$. 14, 15, BC 56534 , latex cast and ventral internal mould, $\times 4$. 16, 17, BC 56664, latex cast and ventral internal mould, $\times 4$. 18, BC 57592, ventral exterior, $\times 4$. 19, 20. BC 56663, holotype, internal mould and latex cast of dorsal valve, $\times 4$.

Figs 21-33 Gacella institata sp. nov. 21-25, 32, 33. Sample 100, Anderkenyn-Akchoku section; 21-25, BC 57496, conjoined valves, posterior, anterior, dorsal, ventral and lateral views, $\times 2 ; 32,33$, BC 57500, conjoined valves, holotype, dorsal and ventral internal moulds, $\times 2.26,27$, Sample 85258 , Kujandysai section, BC 56576, latex cast and dorsal internal mould, $\times 3$. 28-31. Sample 626, Anderkenyn-Akchoku section, BC 57497, conjoined valves, anterior, ventral, lateral and dorsal views, $\times 2$. 

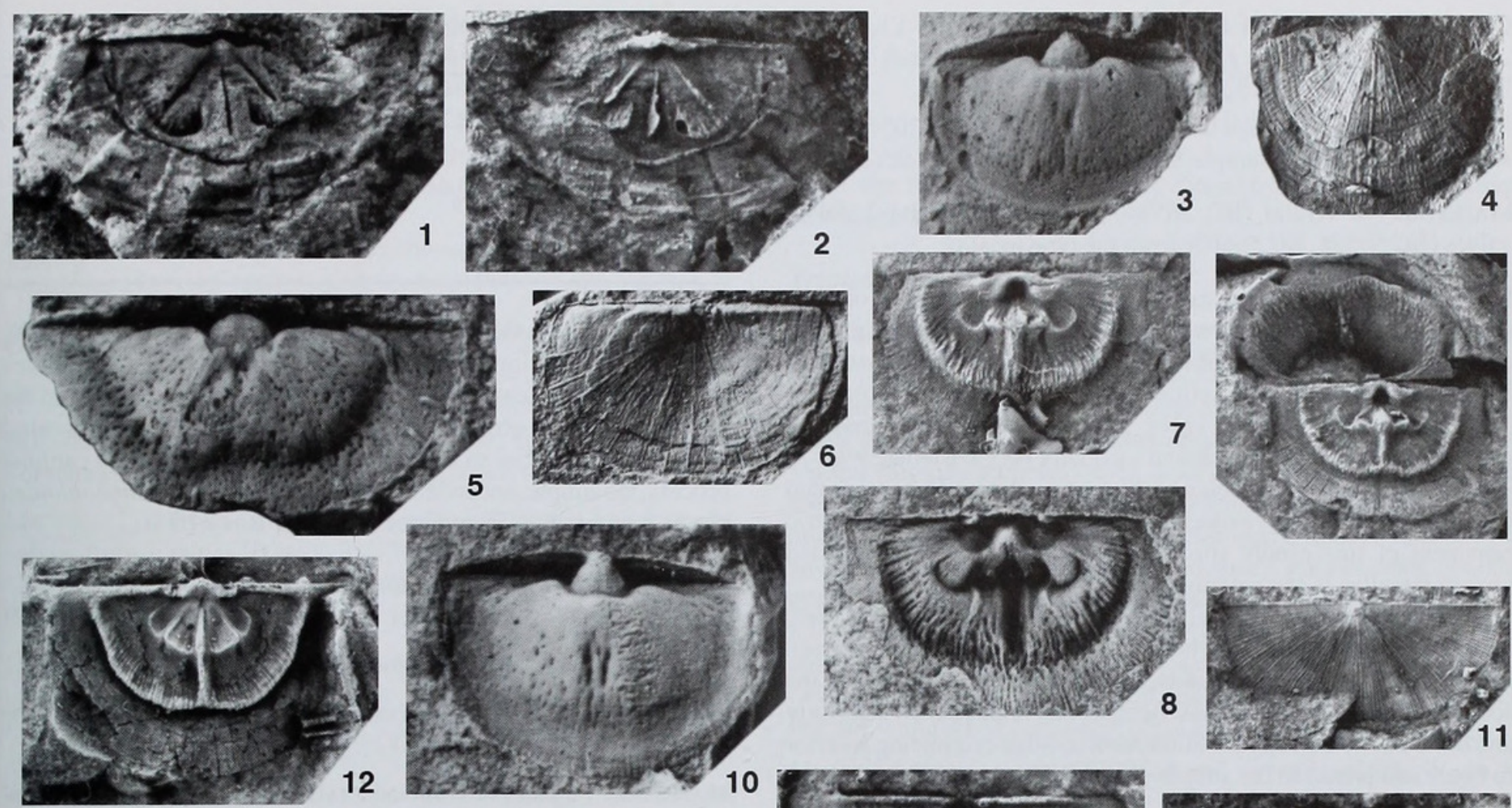
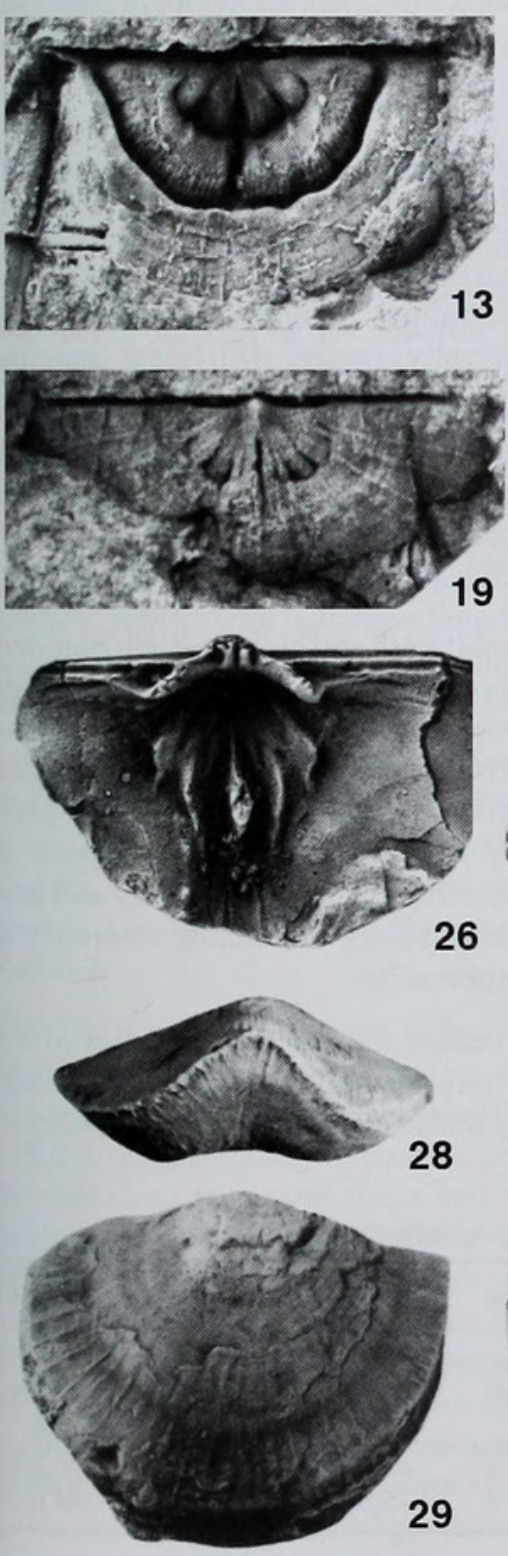
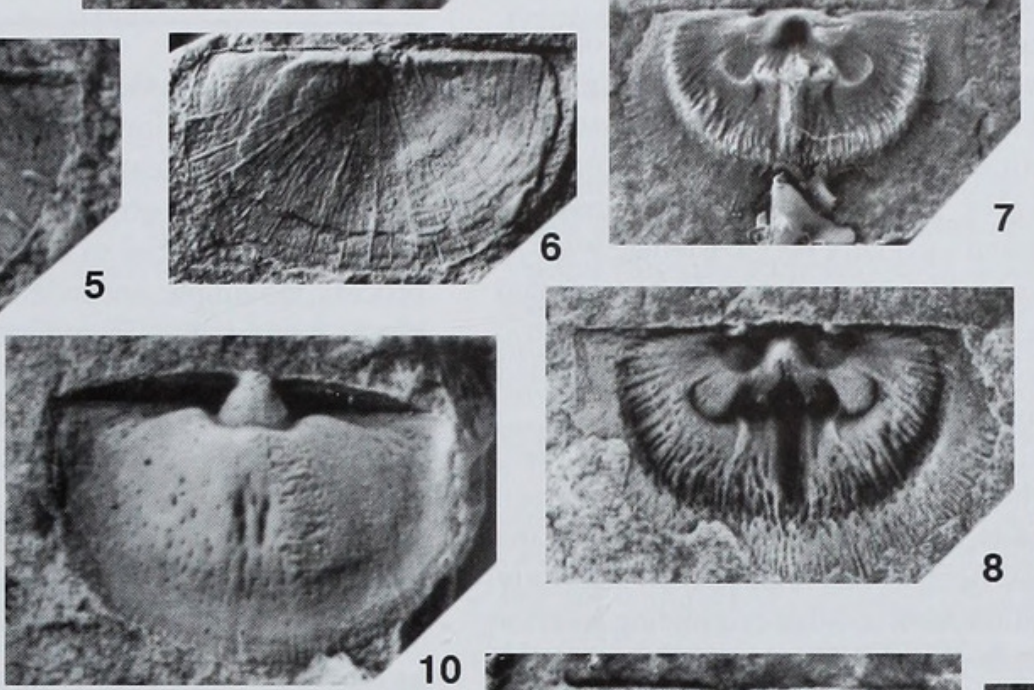

8
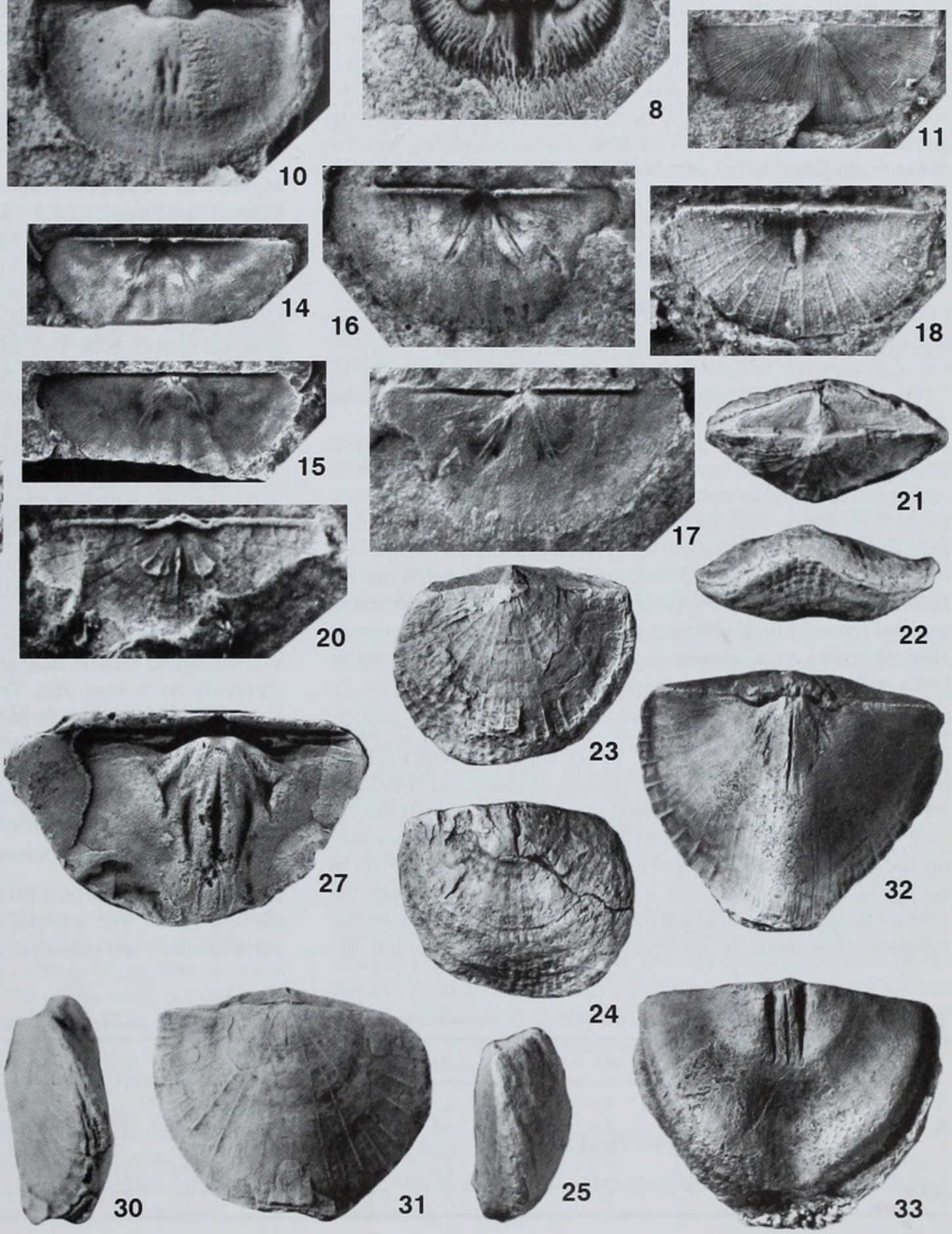

24
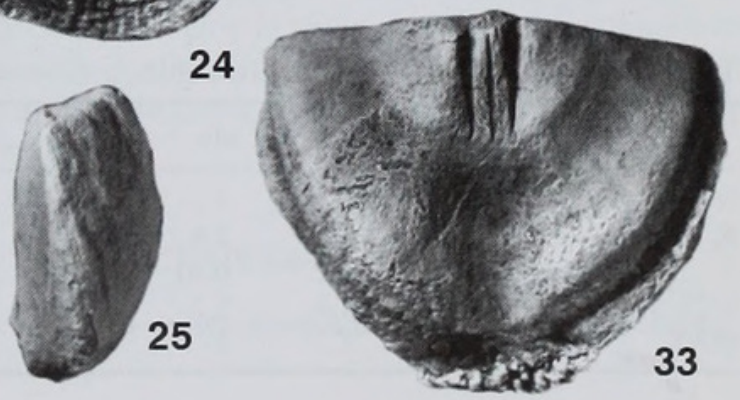
Olgambonites insolita sp. nov.

Pl. 8, figs $11,14-20$

ETYMOLOGY. After insolitus, Latin -extraordinary.

Holotype. BC 56663, a dorsal valve (Pl. 8, figs 19, 20) from the Anderken Formation, Sample 8255, Anderkenyn-Akchoku section.

MATERIAL. 3 ventral (BC 56534-36, BC 56664) and 2 dorsal valves (BC 56538, BC 56663) from the type locality.

DESCRIPTION. Shell convexoconcave, semielliptical in outline, about half as long as wide, with maximum width at the hinge line, and acute cardinal extremities. Ventral valve gently concave in lateral profile with apsacline interarea and narrow convex pseudodeltidium. Dorsal valve gently convex with anacline pseudointerarea. Radial ornament inequally parvicostellate with $7-$ 9 primary accentuated ribs and two generations of accentuated costellae. Very fine parvicostellae, about $10-11$ per $\mathrm{mm}$. Concentric ornament of fine evenly spaced rugellae and very fine crowded growth lamellae in the anterior half of the shell.

Ventral interior with small teeth and highly raised, rounded, subrectangular muscle field bordered anteriorly by the steep rim. Dorsal interior with simple undercut cardinal process joined to the socket ridges and small alveolus. Bema entire, highly raised anteriorly and bordered by a steep rim. Short median ridge originating anterior to bema and joined to the subperipheral rim.

Discussion. The new species is known only from the type locality.

\section{Genus ZHILGYZAMBONITES gen. nov.}

Etymology. After Zhilgyz well, Betpak-Dala Desert.

TYPE SPECIES. Zhilgyzambonites extenuata sp. nov. from the Anderken Formation, Chu-Ili Range.

DIAGNOSIS. Shell concavoconvex, with rectimarginate posterior commissure, ventral interarea apsacline with delthyrium completely covered by pseudodeltidium; dorsal interarea anacline with complete chilidium; radial ornament finely and unequally parvicostellate; ventral valve with small teeth lacking dental plates; ventral muscle field small, highly raised anteriorly; dorsal interior with undercut cardinal process joined to socket ridges, deep alveolus and strongly elevated, entire bema; median ridge fine, originating anteriorly to bema and joined anterioriy to the subperipheral rim.

Discussion. Zhilgyzambonites is somewhat similar to Aulie (Nikitin \& Popov in Klenina et al. 1984), which is within the Hesperomenidae, in the characteristic pseudodeltidium and chilidium, the ventral valve, which lacks dental plates and has a small muscle field which is strongly raised anteriorly, and the dorsal interior with the deep alveolus and an undercut cardinal process; but it differs in having an elevated bema and a short median ridge between the anterior margin of the bema and the subperipheral rim. However, the presence of a bema in Zhilgyzambonites places it within the
Table 17 Measurements of ventral valves of Zhilgyzambonites extenuata sp. nov., Samples 2531, 8251, 8255, from Anderkenyn-Akchoku section.

\begin{tabular}{lllc}
\hline & Lv & W & Lv/W \\
\hline $\mathrm{N}$ & 7 & 7 & 7 \\
$\mathrm{X}$ & 3.7 & 5.2 & $70.9 \%$ \\
$\mathrm{~S}$ & 0.78 & 0.97 & 5.4 \\
MIN & 2.2 & 3.2 & $61.1 \%$ \\
MAX & 4.4 & 6.2 & $78.6 \%$ \\
\hline
\end{tabular}

Sowerbyellidae on the criteria established by Cocks \& Rong (1989). The dorsal interior of the new genus somewhat resembles Diambonioidea (Zeng 1987), but the Kazakh genus differs from the latter in having a strongly raised ventral muscle field, a ventral median ridge anterior to the muscle field, and an undercut cardinal process; the simple, not undercut, cardinal process of Diambonioidea places it within the Grorudiidae (Cocks \& Rong 2000).

\section{Zhilgyzambonites extenuata sp. nov.}

$$
\text { Pl. 8, figs 3, 4, 6-10, 12, } 13
$$

ETYMOLOGY. After extenuatus, Latin - little, weak.

HolOTYPE. BC 12915, a dorsal valve (Pl. 8, figs 12, 13) from the Anderken Formation, Sample 8255, Anderkenyn-Akchoku section.

MATERIAL. 2 pairs of conjoined valves, 10 ventral and 10 dorsal valves from Samples 2531 (BC 57490, 92), 8255 (BC 12915-21, $57493,94)$ and possibly 8215 (BC 57089, 91, 57491), AnderkenynAkchoku section.

DESCRIPTION. Shell concavoconvex, semielliptical in outline, on average $70 \%$ as long as wide with maximum width at the hinge line. Cardinal extremities nearly right angled. Ventral valve moderately and evenly convex in lateral profile with apsacline interarea and narrow convex pseudodeltidium completely covering the delthyrium. Dorsal valve moderately concave with linear, anacline interarea and convex chilidium. Radial ornament unequally parvicostellate with 7-9 accentuated primary ribs and two generations of accentuated costellae. Parvicostellae very fine, about 10-11 per $\mathrm{mm}$. Concentric ornament of fine evenly spaced rugellae and very fine crowded growth lamellae in the anterior half of the shell.

Ventral valve interior with small teeth and highly raised, rounded, subrectangular muscle field about $20 \%$ valve length and bordered anteriorly by a steep rim. Dorsal interior with simple undercut cardinal process joined to narrow, strongly curved socket ridges; small alveolus. Dorsal adductor scars with anterior pair slightly larger than posterior, strongly impressed, divided by a pair of transmuscle septa. Bema entire, strongly raised anteriorly and bordered by a steep rim. Short median ridge originating anteriorly to bema and joined to the subperipheral rim.

DisCUSSION. As far as is yet known, this is the only species within the new genus. The material from Sample 8215 does not include valve internals and is thus only doubtfully referred to the species.

Table 18 Measurements of dorsal valves of Zhilgyzambonites extenuata sp. nov., Samples 2531, 8251, 8255, from Anderkenyn-Akchoku section.

\begin{tabular}{|c|c|c|c|c|c|c|c|c|c|c|c|c|c|c|}
\hline & $\mathrm{Ld}$ & W & Ml & $\mathrm{Mw}$ & LPI & $\mathrm{LPw}$ & $\mathrm{BBl}$ & $\mathrm{BBw}$ & $\mathrm{Ld} / \mathrm{W}$ & $\mathrm{Ml} / \mathrm{Ld}$ & $\mathrm{Ml} / \mathrm{Mw}$ & $\mathrm{PLI} / \mathrm{Ld}$ & $\mathrm{LPw} / \mathrm{W}$ & $\mathrm{BBw} / \mathrm{W}$ \\
\hline $\mathrm{N}$ & 8 & 8 & 3 & 3 & 3 & 3 & 3 & 3 & 8 & 3 & 3 & 3 & 3 & 3 \\
\hline X & 3.8 & 6.1 & 1.5 & 2.6 & 2.9 & 4.8 & 0.3 & 2.3 & $62.5 \%$ & $35.1 \%$ & $58.6 \%$ & $67.4 \%$ & $73.9 \%$ & $35.7 \%$ \\
\hline S & 0.53 & 0.67 & 0.17 & 0.40 & 0.21 & 0.20 & 0.06 & 0.72 & 6.0 & 2.4 & 10.3 & 7.2 & 0.3 & 12.6 \\
\hline MIN & 3 & 5.2 & 1.4 & 2.2 & 2.7 & 4.6 & 0.3 & 1.7 & $54.0 \%$ & $33.3 \%$ & $46.7 \%$ & $62.2 \%$ & $73.5 \%$ & $26.2 \%$ \\
\hline MAX & 4.5 & 6.8 & 1.7 & 3 & 3.1 & 5 & 0.4 & 3.1 & $71.7 \%$ & $37.8 \%$ & $65.4 \%$ & $75.6 \%$ & $74.2 \%$ & $50.0 \%$ Order \\
\hline
\end{tabular}


ORTHOTETIDA Waagen, 1884

Suborder ORTHOTETIDINA Waagen, 1884

Superfamily CHILIDIOPSOIDEA Boucot, 1959

Family CHILIDIOPSIDAE Boucot, 1959

Subfamily GACELLINAE Williams \& Brunton, 2000

Genus GACELLA Williams, 1962

TYPE SPECIES. Gacella insolita Williams, 1962, from the Stinchar Limestone (Lower Caradoc), Girvan, Scotland.

Gacella institata sp. nov. Pl. 8, figs 21-33, Pl. 9, figs 1-4

ETYMOLOGY. After instita, Latin - a swathe.

Holotype. BC 57500, Pl. 8, figs 32, 33, from the Anderken Formation, Sample 100, Anderkenyn-Akchoku section.

MATERIAL. 10 pairs of conjoined valves, 2 ventral and 8 dorsal valves, from Samples 100 (=K-98/1970) (BC 57496, 98, 99, 57500), 626 (BC 57497), Anderkenyn-Akchoku section; Samples 628, 85258 (BC 57092-3, 56576), Kujandysai Section..

DESCRIPTION. Shell subequally biconvex, transverse, semielliptical in outline about $80 \%$ as long as wide, with maximum width at hinge line. Cardinal extremities acute to rectangular. Anterior commissure gently uniplicate. Ventral valve convex in lateral profile with maximum thickness slightly anterior to the umbo and with flattened sides. Sulcus shallow, originating about $2-3 \mathrm{~mm}$ from the umbo. Ventral interarea planar, apsacline with a broad, convex pseudodeltidium perforated apically by a minute foramen. Lateral profile of the dorsal valve gently convex with maximum thickness near the anterior margin. Dorsal median fold low, rounded in cross-section, originating in the umbonal area but very weakly defined until the mid-valve. Dorsal interarea planar, anacline, with convex chilidium. Radial ornament unequally parvicostellate with two to three generations of acentuated ribs, about 4-5 per $3 \mathrm{~mm}$ along the anterior margin of mature specimens. Concentric ornament of numerous fine growth lamellae anteriorly.

Ventral interior with teeth supported by long subparallel but slightly divergent dental plates and narrow, elongate subtriangular muscle field divided by median ridge. Numerous fine crenulations on the outer surface of the teeth. Dorsal interior with bilobed cardinal process on a high notothyrial platform: adductor scars elongated slightly, shorter than half valve length, crossed by two pairs of short transmuscle septa. Median ridge fine and faint, originating some distance from the notothyrial platform.

MEASUREMENTS. (471/12375) conjoined valves, $\mathrm{L}=14.0, \mathrm{~W}=16.9$, $\mathrm{T}=6.3, \mathrm{Sw}=8.9 ;(474 / 12375)$ conjoined valves, $\mathrm{L}=20.4, \mathrm{~W}=21.0$, $\mathrm{T}=11.2, \mathrm{Sw}=8.7 ;(475 / 12375)$ conjoined valves, $\mathrm{L}=22.9, \mathrm{~W}=24.5$, $\mathrm{T}=10.2, \mathrm{Sw}=12.8 ;(476 / 12375)$ conjoined valves, $\mathrm{L}=16.5, \mathrm{~W}=19.8$, $\mathrm{T}=6.5, \mathrm{Sw}=11.2 ;(479 / 12375)$ conjoined valves, $\mathrm{L}=10.5, \mathrm{~T}=6.7$, $\mathrm{Sw}=6.7$.

Discussion. This species differs from others of the genus in having a concentric ornament of strong growth lamellae and coarser accentuated ribs. It can be compared to Gacella ponderosa Williams, 1962, from the Confinis Formation (Llandeilo) of Girvan, south Scotland, in the general shape and size of the shell, but differs in having a less convex lateral profile in both valves in addition to the patterns of radial and concentric ornament.

Gacella institata differs from $G$. sulcata Misius (in Misius \& Ushatinskaya 1977), from the Tabylgaty Formation (Upper Caradoc) of the Moldo-Too Range, Kyrgizstan, in having a shallow ventral median sulcus and low dorsal median fold usually originating in the umbonal region; the convex, not flat, lateral profile of the ventral valve, and in the absence of geniculation in the dorsal valve.
Suborder TRIPLESIIDINA Moore, 1952

Superfamily TRIPLESIOIDEA Schuchert, 1913

Family TRIPLESIIDAE Schuchert, 1913

GENUS TRIPLESIA Hall, 1859

TYPE SPECIES. Atrypa extans Emmons, from the Trenton Group (Caradoc), New York, U.S.A.

\section{Triplesia sp.}

Pl. 9, figs 22-26

MATERIAL. Two ventral and three dorsal valves (BC 57512) from Sample 8228, Kopalysai.

DESCRIPTION. Shell dorsibiconvex, transverse suboval in outline, about $80 \%$ as long as wide with uniplicate anterior commissure. Ventral valve moderately convex, with maximum thickness at about one-third valve length. Ventral interarea anacline. Sulcus originating near mid-valve, strongly deepening anteriorly, flanked laterally by angular plications. Dorsal valve moderately convex with swollen umbo. Strong median fold with steep sides, originating anteriorly of mid-valve, bisected medianly by fine groove. Shell surface smooth with rare, slightly irregular growth lamellae anteriorly. Ventral interior with teeth supported by short subparallel dental plates. Dorsal interior with forked cardinal process on a short shaft.

MEASUREMENTS. (488/12375) dorsal valve, $\mathrm{L}=16.2, \mathrm{~W}=16.9$, $\mathrm{T}=4.5$.

DisCUSSION. These shells are comparable with large specimens of Triplesia aff. subcarinata, but differ in having a narrow groove bisecting the dorsal median fold and a ventral sulcus which is more rounded in cross-section and a dorsal median fold. However, the shape of the dorsal fold and ventral sulcus varies significantly and it is difficult to evaluate observed morphological differences in this species because of the small number of shells available.

Triplesia aff. subcarinata Cooper, 1956

Pl. 10, figs $1-8,19$

MATERIAL. 6 conjoined valves, 2 ventral and 3 dorsal valves from Samples 100 (=K-98/1970), 626 (BC 57515), 8251a (BC 57514), Anderkenyn-Akchoku section; Samples 85258 (BC 57094-5), Kujandysai section; Sample 1041a, Burultas Valley.

Discussion. This species resembles Triplesia carinata Cooper, 1956, from the Pratt Ferry Formation of Alabama and T. subcarinata Cooper, 1956, from the Lebanon Formation of Tennessee, as well as specimens of that species from the Bestamak Formation (LlandeiloLower Caradoc) of the Chingiz range, Kazakhstan (Nikitin \& Popov in Klenina et al.1984), in having a well-developed sulcus and a carinate dorsal median fold originating near the mid length, but it differs from both in having a larger shell, a strongly convex lateral profile in the dorsal valve with maximum height near the anterior margin, and a variable transverse profile of the dorsal median fold which has a tendency to be rounded in most specimens. Triplesia aff. subcarinata differs from T. ainca Severgina, 1978, from the Lower Ashgill Gurianovka Formation and Marinikha Limestone of the Sayano-Altai Mountain Region in having a strongly dorsibiconvex lateral profile with a slightly accentuated ventral beak erect posteriorly, a narrow ventral sulcus and a dorsal median fold usually rounded in cross-section.

\section{Genus BICUSPINA Havlí̌ek, 1950}

TYPE SPECIES. Orthis cava Barrande, 1848, from the Lower Caradoc of Bohemia. 
L.E. POPOV, L.R.M. COCKS AND I.F. NIKITIN
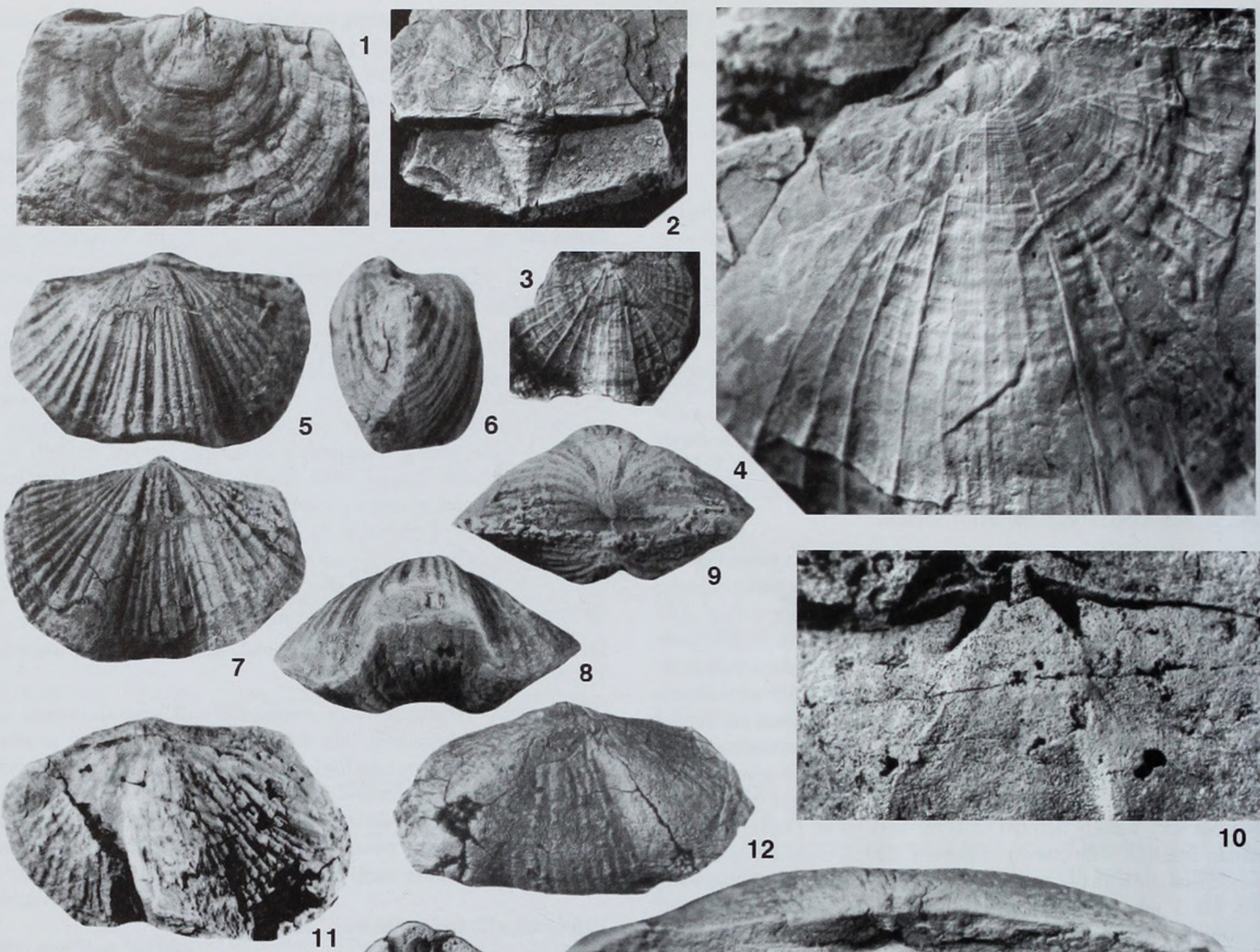

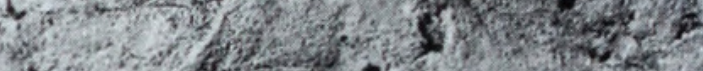

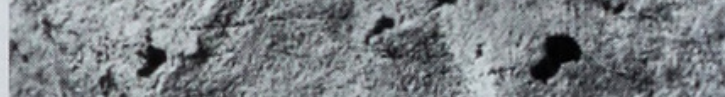

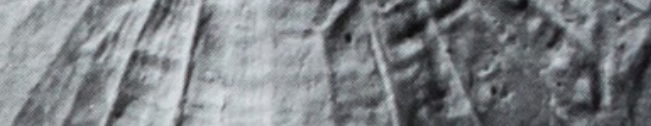
(a)
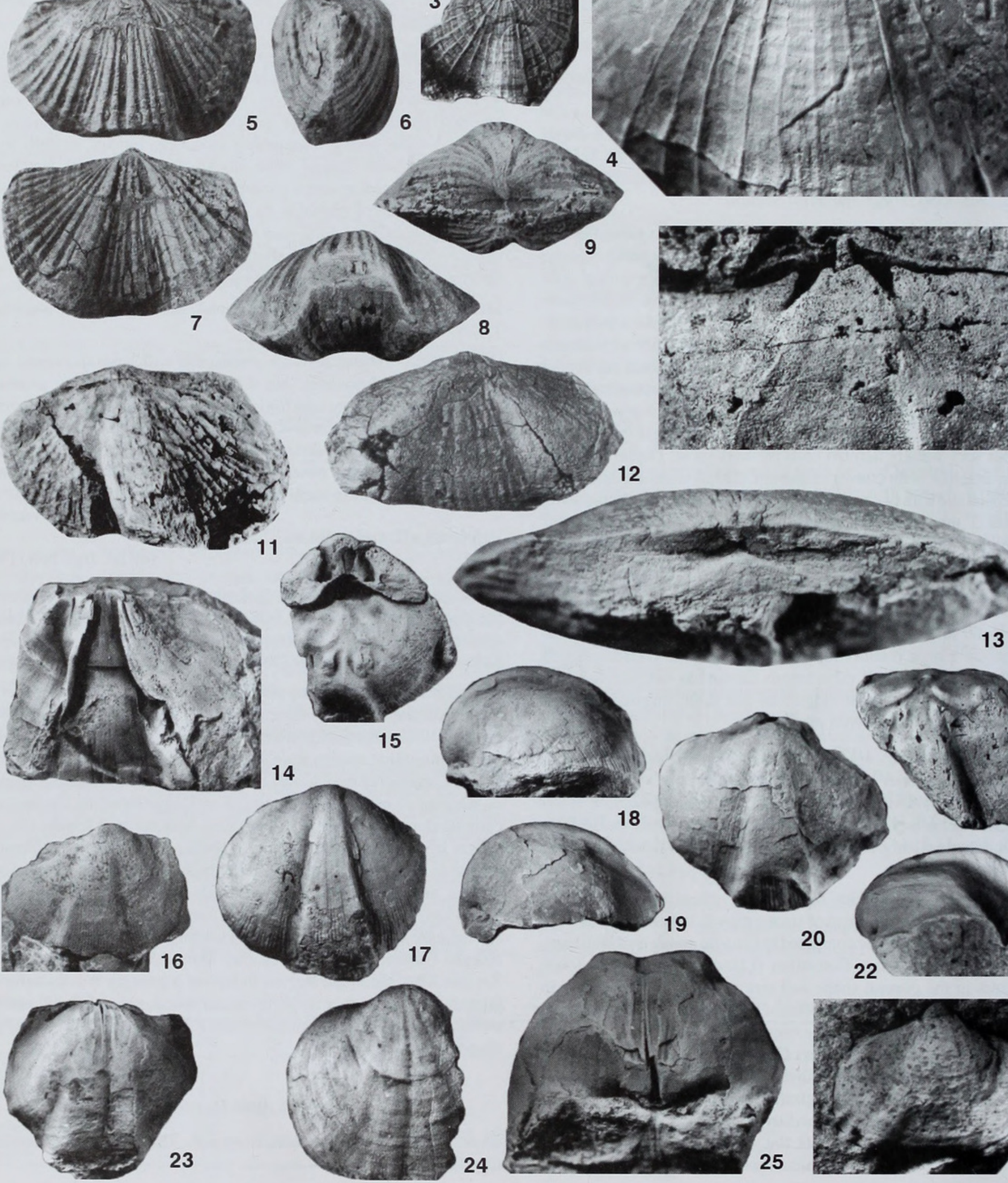

20

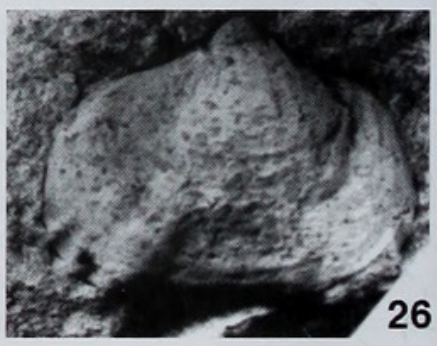




\section{Bicuspina rukavishnikovae Klenina, 1984 Pl. 9, figs 5-13}

1984 Bicuspina rukavishnikovae Klenina in Klenina et al.: 62, pl. 5, figs 7,8 .

1985 Bicuspina attrita Popov: 61, pl. 3, figs 2-4.

HoLOTYPE. IGNA 411/89, conjoined valves, from the Abai Formation (Lower Caradoc), Ordotas Mountains, Chingiz Range, Kazakhstan.

MATERIAL. Five conjoined valves, one ventral and 9 dorsal valves from Samples 100 (=K-98/1970) (BC 57505), 626, AnderkenynAkchoku section; Sample 1018 (including the holotype of B. attrita CNIGR 32/11989), area 7 km southwest of Karpkuduk well, Kotnak Mountains.

DESCRIPTION. Shell dorsibiconvex, about half as thick as long and about $90 \%$ as long as wide. Hinge line short, about two-thirds maximum width. Ventral valve gently convex in lateral profile with maximum thickness at about one-third valve length. Beak small, slightly curved. Ventral interarea low, planar, apsacline with small pseudodeltidium bisected by monticulum. Ventral median sulcus originating in umbonal area with flattened bottom and steep lateral sides about $60 \%$ valve width. Well-developed semioval tongue. Dorsal valve strongly convex with maximum thickness at midlength and flattened umbonal area. Median fold high, originating near umbo, with steep lateral slopes. Radial ornament costellate with 6-11 ribs in the fold and sulcus and 13-21 ribs on the lateral sides of mature shells.

Ventral interior with small teeth supported by short diverging dental plates. Ventral muscle field open anteriorly, weakly impressed. Umbonal area with a short internal pedicle tube (Pl. 9, fig.10). Dorsal interior with forked cardinal process on a short, thickened shaft, and small curved socket ridges.

MEASUREMENTS. (471/12375) conjoined valves, $\mathrm{L}=14.0, \mathrm{~W}=16.9$, $\mathrm{T}=6.3, \mathrm{Sw}=8.9 ;(474 / 12375)$ conjoined valves, $\mathrm{L}=20.4, \mathrm{~W}=21.0$, $\mathrm{T}=11.2, \mathrm{Sw}=8.7 ;(475 / 12375)$ conjoined valves, $\mathrm{L}=22.9, \mathrm{~W}=24.5$, $\mathrm{T}=10.2, \mathrm{Sw}=12.8 ;(476 / 12375)$ conjoined valves, $\mathrm{L}=16.5, \mathrm{~W}=19.8$, $\mathrm{T}=6.5, \mathrm{Sw}=11.2 ;(479 / 12375)$ conjoined valves, $\mathrm{L}=10.5, \mathrm{~T}=6.7$, $\mathrm{Sw}=6.7$.

DISCUSSION. Coarsely ribbed triplesiides are characteristic of the Caradoc of West Gondwana (Havlícek 1950; Melou 1990) and Avalonia (Williams 1963; 1974), but they are apparently absent from China and Australia and very rare in Kazakhstan. Specimens from the Chu-Ili Range were previously known as Bicuspina attrita Popov (1985). They differ from Bicuspina rukavischnikovae, described by Klenina (in Klenina et al. 1984) from the Abai Formation of the Chingiz Range, only in having a slightly uneven lateral profile of the ventral valve with maximum height posterior to midlength, and in a more apsacline ventral interarea. These differences are regarded here as intraspecific, and specimens of Bicuspina from the Chu-Ili and Chingiz ranges are therefore conspecific. Klenina mentioned the presence of a forked cardinal process and internal pedicle tube in the original description of the species, but the interiors of both valves were not illustrated.

The published Llanvirn age of B. rukavischnikovae in the Ordotas Mountains of the Chingiz Range, which is the type locality, is not supported by analysis of the associated brachiopod assemblage. It co-occurs with Hesperorthis karaadirensis Klenina, which is probably synonymous with Paralenorthis numerosa (Nikitin \& Popov) and rhynchonellids, suggesting that the age of the assemblage is not older than Llandeilo to early Caradoc.

\section{Genus GRAMMOPLECIA Wright \& Jaanusson, 1993}

TYPE SPECIES. Grammoplecia triplesioides Wright \& Jaanusson, 1993, from the Boda Limestone (Ashgill) of Dalarna, Sweden.

\section{Grammoplecia wrighti sp. nov. $\quad$ Pl. 9, figs 14-21}

ETYMOLOGY. After A.D. Wright, to honour his triplesioid studies.

Holotype. BC 57509, Pl. 9, figs 17, 18, a dorsal valve from the Anderken Formation, Sample 8214, Anderkenyn-Akchoku section.

MATERIAL. Three pairs of conjoined valves, three ventral and 9 dorsal valves, from Samples 620 (BC 57100-04, 57506, 07, 10, 11), 626 (BC 57105-6), Anderkenyn-Akchoku section; Samples 8214 (BC 57099, 57508-11), 8215b (BC 57107), west side of Ashchisu River; Sample 628, Kujandysai Section,.

DESCRIPTION. Shell dorsibiconvex, slightly transverse, subrectangular to suboval in outline, about $83 \%$ as long as wide. Hinge line straight, not exceeding two-thirds shell width. Anterior commissure uniplicate. Ventral valve moderately convex with low, apsacline interarea and flat pseudodeltidium bisected by monticulum. Ventral sulcus originating about $3-5 \mathrm{~mm}$ from the umbo, ending in wide, trapezoidal tongue about $83 \%$ as wide as the valve. Dorsal valve strongly convex with maximum thickness at about one-third valve length. Strong dorsal median fold, flat centrally with steep lateral slopes. Lateral slopes convex in cross-section, strongly inclined to the commissural plane. Radial ornament of fine capillae about 5-7 per $\mathrm{mm}$ crossed by fine, closely-spaced concentric fila.

Ventral interior with strong teeth and long, diverging, widely spaced dental plates. Ventral muscle field large, about two-fifths valve length, slightly raised anteriorly with wide, subtriangular adductor track dividing narrow, strip-like diductor scars. Dorsal interior with forked cardinal process on strong short shaft joined to low and short socket plates. Adductor field quadripartite with anterior and posterior pairs separated by strong, transverse ridges. Low

\section{PLATE 9}

Figs 1-4 Gacella institata sp. nov., Sample 100, Anderkenyn-Akchoku section. 1, BC 57498, ventral valve, umbonal area, $\times 5.2$, Sample 100, BC 57502, enlargement of interarea of conjoined valves, $\times 3.3,4$, BC 57499, dorsal valve exterior, $\times 2$, and umbonal area showing radial ornament, $\times 6$.

Figs 5-13 Bicuspina rukavishnikovae Klenina, 1984. 5-9, Sample 100, Anderkenyn-Akchoku section, BC 57505, conjoined valves, dorsal, lateral, ventral anterior and posterior views, $\times 2$. 10-13, Sample 1018, area 7 km southwest of Karpkuduk well, Kotnak Mountains; 10, CNIGR 31/11989, ventral internal mould showing internal pedicle tube, $\times 5$; 11, CNIGR 32/11989, dorsal exterior, $\times 2$; 12, 13, CNIGR 33/11989, conjoined valves, ventral view, $\times$ 2 , posterior view, $\times 5$.

Figs 14-21 Grammoplecia wrighti sp. nov. Anderkenyn-Akchoku section. 14, 15, 19-21, Sample 620; 14, BC 57506, ventral internal mould, $\times 2$; 15, BC 57507 , conjoined valves, oblique posterior view of internal mould showing cardinal process, $\times 2 ; \mathbf{1 9}, \mathbf{2 0}$, BC 57510, dorsal and lateral views of exterior, $\times$ 2; 21, BC 57511, dorsal internal mould, $\times 2$. 16-18, Sample $8214 ; \mathbf{1 6}$, BC 57508, dorsal exterior, $\times 2$; 17, 18, BC 57509, holotype, dorsal exterior and lateral views, $\times 2$

Figs 22-26 Triplesia sp. Sample 8228, east side of Kopalysai. 22, 23, 25, dorsal internal mould, lateral and dorsal views, $\times 2$, posterior view showing cardinal process, $\times 3 . \mathbf{2 4}$, BC 57512 , latex cast of dorsal exterior, $\times 2.26$, ventral internal mould, $\times 2$. 


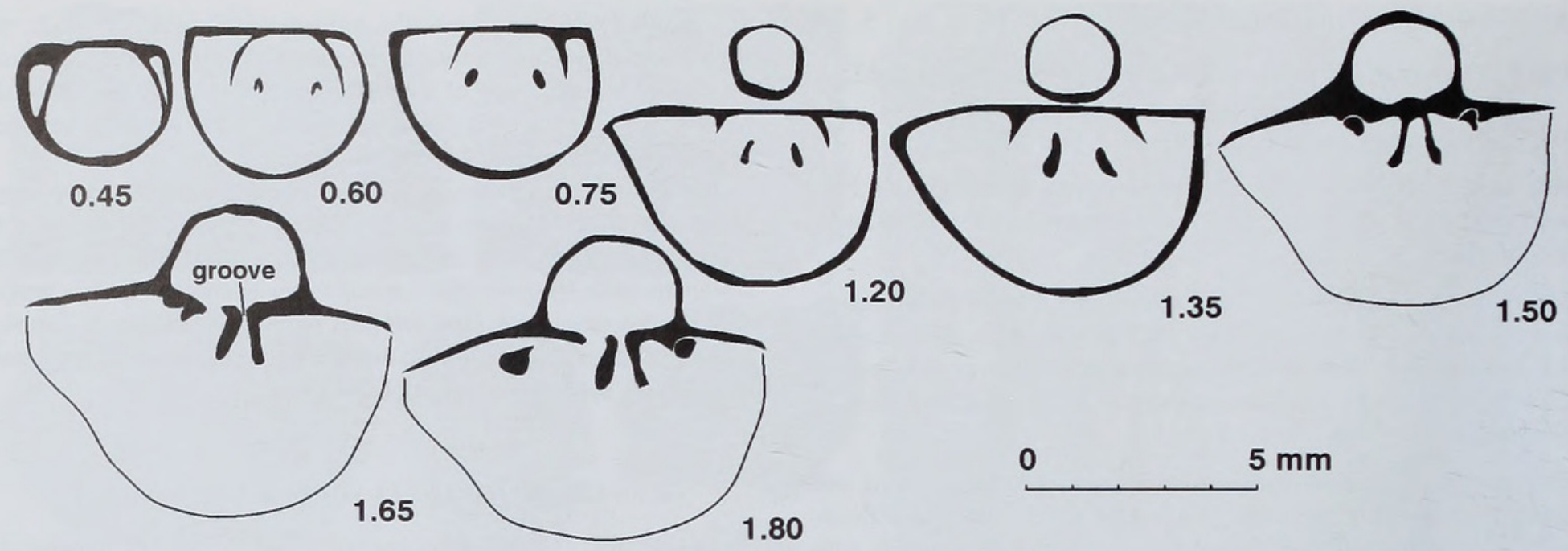

Fig. 13 Transverse serial sections of Placotriplesia spissa sp.nov., BC 57605 from Sample 628. Distance in mm is measured from the posterior tip of ventral beak. Dorsal valve uppermost.

and narrow median ridge extending to anterior border of the muscle field.

MeAsurements. (490/12375) dorsal valve, $\mathrm{L}=17.2, \mathrm{~W}=19.2$, $\mathrm{T}=8.2, \mathrm{Sw}=9.6 ;(491 / 12375)$ dorsal valve, $\mathrm{L}=17.2, \mathrm{~W}=21.0, \mathrm{~T}=8.6$, $\mathrm{Sw}=8.2 ;(495 / 12375)$ dorsal valve, $\mathrm{L}=10.2, \mathrm{~W}=15.3, \mathrm{~T}=7.8, \mathrm{Sw}=4.6$.

DISCUSSION. This species differs from Grammoplecia triplesioides Wright \& Jaanusson, 1993, G. globosa (Nikitin \& Popov, 1985), from the Andryushinka Formation (Llandeilo-Lower Caradoc) of north-central Kazakhstan, G. krotovi (Chernyschev, 1887) from the Upper Caradoc to Lower Ashgill of Novaya Zemlya, Vaigach and the Urals (Bondarev 1968) and G. sibirica (Nikiforova, 1955) from the Upper Caradoc of Siberia, in having a more transverse shell outline, a ventral sulcus and dorsal median fold with steep lateral sides and flat centrally, a strongly and evenly convex dorsal profile with maximum height at mid-length and a broader hinge line.

\section{Genus PLACOTRIPLESIA Amsden, 1968}

TYPE SPECIES. Triplesia praecipta Ulrich \& Cooper, 1936a, from the Wenlock of Arkansas, U.S.A.

\section{Placotriplesia spissa sp. nov.}

Holotype. BC 57517, Pl. 10, figs 9-13, from Sample 2538, Anderken Formation, Akchoku Mountain, Kujandysai section.

MATERIAL. 9 pairs of conjoined valves, 6 ventral and 12 dorsal valves from Samples 8214, 8215, 8223, Anderkenyn-Akchoku section; Samples 628, 2538 (BC 57517), 8219, 8256, Kujandysai section.

DESCRIPTION. Shell smooth, dorsibiconvex profile, about $80 \%$ as thick as long and $75 \%$ as long as wide, transverse and suboval in outline, with maximum width at mid-length. Hinge-line short, less than half valve width. Anterior commissure strongly uniplicate. Ventral valve moderately convex, with an erect beak and minute apical foramen. Ventral interarea high, planar, apsacline with flat pseudodeltidium. Ventral sulcus originating from quarter to half valve length, strongly deepening anteriorly, with strong geniculated tongue about $75 \%$ valve width, and inclined at less than a right angle towards commisural plane. Lateral sides of sulcus accentuated by angular plications. Dorsal valve strongly convex, with swollen incurved beak; dorsal median fold strong and rounded in crosssection. Ventral interior with delicate teeth and short divergent dental plates. Dorsal interior with grooved forked cardinal process with strongly curved prongs posteriorly with distal parts subparallel to commisural plane, separated proximally and fused with narrow curved socket ridges.

Discussion. This species represents the earliest record of

\section{PLATE 10}

Figs 1-8, 19 Triplesia aff. subcarinata Cooper. Anderkenyn-Akchoku section. 1-4, 19, Sample 8251a, BC 57514, conjoined valves, ventral, dorsal, posterior and anterior views, $\times 2$, dorsal view of the umbonal area showing pseudodeltidium with monticulus, $\times 4.5-8$, Sample 100 , BC 57515, conjoined valves, $\times 2$.

Figs 9-18 Placotriplesia spissa sp.nov. 9-14, Sample 2538, Akchoku Mountain, Kujandysai section. 9-13, BC 57517, holotype, conjoined valves, ventral, dorsal, anterior, posterior and lateral views, $\times 2.14$, CNIGR 3/12361, conjoined valves showing ventral interarea with pseudodeltidium lacking monticulum, $\times$ 5. 15-18, Sample 8214, Anderkenyn-Akchoku section, CNIGR 3/12361, conjoined valves, ventral, dorsal, anterior and lateral views, $\times 2$.

Figs 20-22 Skenidioides sp. Sample 8214, west side of Ashchisu River, BC 57518, conjoined valves, ventral, dorsal and posterior views, $\times 6$.

Figs 23-29, 31-36 Dolerorthis pristina sp. nov. 23-25, 32, 34, Sample 626, Anderkenyn-Akchoku section. 23-25, 32, BC 57519, conjoined valves, ventral, lateral and dorsal views, $\times 2$, detail of the shell surface, $\times 8 ; 34$, BC 57522, ventral internal mould, $\times 2$. 26-29, 31, Sample 620, AnderkenynAkchoku section, BC 57520, holotype, conjoined valves, dorsal, ventral, lateral, posterior and anterior views, $\times 2$. 33, 35, Sample 2538, Akchoku Mountain, Kujandysai section; 33, BC 57521, ventral exterior, $\times 2 ; 35$, BC 56768, dorsal interior, $\times 3$. 36, Sample 8214, Anderkenyn-Akchoku section, BC 57523, dorsal internal mould, $\times 2$.

Figs 37-42 Glyptorthis sp., Kujandysai section. 37, Sample 2538, BC 57524, ventral internal mould, $\times 3.38-42$, Sample 628 (=K-107/70), west side of Kujandysai, BC 57525, conjoined valves, anterior, dorsal, lateral and ventral views, $\times 3$, dorsal view, $\times 6$.

Fig. 43 Plectorthis? burultasica sp. nov. Sample 1018, area 7 km SW of Kotnak mountains, south Betpak-Dala, CNIGR 2/11989, latex cast of ventral interior, $\times 2$ 


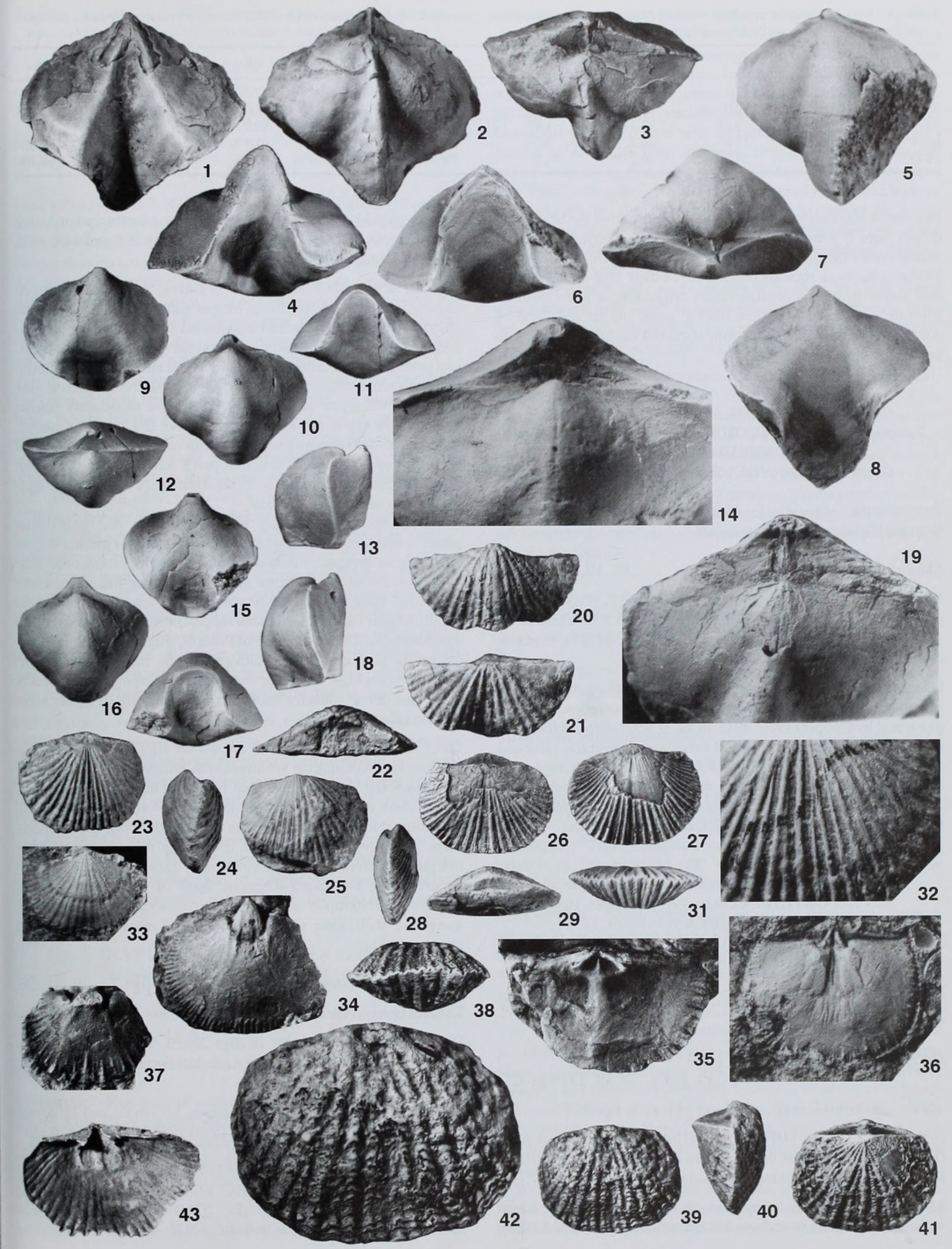


Table 19 Measurements of complete shells of Placotriplesia spissa sp. nov., Sample 2538. Kujandysai section, 8221 from Anderkenyn-Akchoku section and Sample F-1041a from Burultas valley.

\begin{tabular}{|c|c|c|c|c|c|c|c|c|c|}
\hline & $\mathrm{L}$ & W & $\mathrm{T}$ & Sw & $\mathrm{St}$ & $\mathrm{L} / \mathrm{W}$ & $\mathrm{T} / \mathrm{L}$ & $\mathrm{Sw} / \mathrm{W}$ & $\mathrm{St} / \mathrm{Sw}$ \\
\hline $\mathrm{N}$ & 7 & 7 & 7 & 7 & 3 & 7 & 7 & 7 & 3 \\
\hline$X$ & 13.9 & 19.0 & 11.5 & 10.4 & 7.7 & $73.9 \%$ & $81.6 \%$ & $75.5 \%$ & $73.2 \%$ \\
\hline $\mathrm{S}$ & 2.61 & 4.27 & 3.13 & 1.43 & 3.04 & 7.9 & 12.7 & 6.1 & 22.3 \\
\hline MIN & 10.5 & 13.6 & 6.8 & 8.2 & 3.3 & $60.4 \%$ & $61.7 \%$ & $67.9 \%$ & $37.5 \%$ \\
\hline MAX & 16.3 & 24.5 & 14.7 & 11.5 & 7.6 & $83.9 \%$ & $90.2 \%$ & $83.0 \%$ & $69.1 \%$ \\
\hline
\end{tabular}

Placotriplesia, which is otherwise known only from the Silurian. It differs from $P$. praecipta, $P$. juvenis Ulrich \& Cooper (1936a), $P$. waldronensis (Miller \& Dyer), and P. rostellata (Ulrich \& Cooper 1936a) in having a strongly dorsibiconvex shell, high dorsal median fold and deep ventral median sulcus originating at some distance from the umbo. It also differs from $P$. praecipta, as redefined by Amsden (1968), in having a strongly curved cardinal process with posteriorly-directed prongs.

Order PROTORTHIDA Schuchert \& Cooper, 1931 Superfamily PROTORTHOIDEA Schuchert \& Cooper, 1931 Family SKENIDIIDAE Kozlowski, 1929

Genus SKENIDIOIDES Schuchert \& Cooper, 1931

TYPE SPECIES. Skenidioides billingsi Schuchert \& Cooper, 1931, from the Caradoc of Ontario, Canada.

\section{Skenidioides sp.}

Pl. 10, figs 20-22

MATERIAL. One pair of conjoined valves $(\mathrm{L}=2.7, \mathrm{~W}=5.4, \mathrm{~T}=1.7)$, one ventral and one dorsal valves from Samples 8223b and 8226 , Anderkenyn-Akchoku section; Sample 8214 (BC 57518), west side of Ashchisu River.

Discussion. The shells from the Anderken Formation closely resemble Skenidioides anthonensis (Sardeson), as redescribed and illustrated by Cooper (1956: 491), in the general shape of the shell, narrow median sulcus in the dorsal valve, carinate ventral valve and characters of radial ornament, but differ somewhat in having a more flattened dorsal valve. Although the exterior is characteristic of Skenidioides, the absence of known interiors in the specimens from the Anderken Formation precludes specific identification.

Order ORTHIDA Schuchert \& Cooper, 1932 Suborder ORTHIDINA Schuchert \& Cooper, 1932

Superfamily ORTHOIDEA Woodward, 1852 Family HESPERORTHIDAE Schuchert \& Cooper, 1931 Genus DOLERORTHIS Schuchert \& Cooper, 1931

TYPE SPECIES. Orthis interplicata Foerste, from the Niagara Group (Silurian) of Indiana, U.S.A.

\section{Dolerorthis expressa Popov, 1980}

$$
\text { Pl. 1, fig. 29, Pl. 11, figs } 1,2
$$

1980 Dolerorthis expressa Popov: 144, pl. 1, figs 5-7.

HOLOTYPE. CNIGR 11/11523, ventral internal and external moulds ( $\mathrm{L}=18.4, \mathrm{~W}=24,7$ ), from the Anderken Formation, Sample 1018, 7 km southwest of Karpkuduk well, Kotnak Mountains.

MATERIAL. One pair of conjoined valves, 12 ventral and 11 dorsal valves, internal and external moulds, from Sample 8137 (BC 57526),
Anderkenyn-Akchoku; Sample 817, about 4 km south-west of Alakul Lake; Sample 1018 (BC 57368),7 km southwest of Karpkuduk well, Kotnak Mountains, south Betpak-Dala.

DESCRIPTION. Shell subequally biconvex, transverse, subrectangular in outline, about $75 \%$ as long as wide with maximum width anterior to hinge line. Cardinal extremities slightly rounded; anterior commissure weakly unisulcate; ventral valve gently convex in lateral profile with maximum thickness at about one-third from anterior margin; ventral interarea apsacline, slightly curved in cross-section with open triangular delthyrium. Dorsal valve moderately convex with shallow sulcus originating at the umbo. Interarea low, planar, anacline. Radial ornament variably multicostellate with costellae of two to three generations. $4-6$ ribs per $3 \mathrm{~mm}$ along the posterior margin of adult specimens. Concentric ornament of fine, ridge-like, evenly spaced fila, 3-4 per mm.

Ventral interior with strong teeth supported by diverging dental plates continuing anteriorly as elevated muscle bounding ridges enclosing an elongate, subrhomboidal muscle field about two-fifths as long as the valve. Adductor scars narrow, strip-like, completely separating large, deeply impressed diductor scars of about equal length. Mantle canals saccate with subparallel to slightly converging vascula media. Dorsal interior with simple, ridge-like cardinal process on the high notothyrial platform slightly inclined posteriorly. Brachiophores high, triangular with slightly diverging bases. Weakly impressed dorsal adductor scars divided posteriorly by a very short median ridge.

Discussion. This species is somewhat similar to Dolerorthis tenuicostata Williams (in Whittington \& Williams 1955: 406) from the Lower Caradoc of Wales, but differs in having a more transverse shell outline, lateral profile of the ventral valve with maximum thickness anterior to the mid-length in full grown specimens and a weak dorsal sulcus continuing towards the anterior margin. It differs from Dolerorthis aff. hubeiensis Zeng, which occurs in the Dulankara Regional Stage of north Betpak-Dala, Kazakhstan (Nikitin et al. 1996), in having a subequally biconvex transverse shell, finer radial ornament and more widely spaced concentric fila.

Dolerorthis pristina sp. nov. Pl. 10, figs 23-29, 31-36

ETYMOLOGY. After pristinus, Latin - former.

HolotyPE. BC 57520, Pl. 10, figs 26-29, 31, conjoined valves ( $\mathrm{L}=9.7, \mathrm{~W}=12.6, \mathrm{~T}=4.2$ ) from the Anderken Formation, Sample 620, Anderkenyn-Akchoku section.

MATERIAL. 8 pairs of conjoined valves, 15 ventral and 18 dorsal valves from Samples 100 (=K-98/1970) (BC 57110-7), 620 (BC 57520), 626 (BC 57130-32, 57519), 8223a (BC 57158, 59), 8223b, Anderkenyn-Akchoku; Sample 8214 (BC 57150-54, 57523), Ashchsu River; Samples 628 (BC 57133-5), 2538 (BC 56768, 57141-45, 57521, 22), 8217 (BC 57156-7), Kujandysai near Akchoku Mountain; Sample 948 (BC 57136-40), Tesik River. 
Table 20 Measurements of complete shells of Dolerorthis pristina sp. nov., Samples 100 and 626 from Anderkenyn-Akchoku section.

\begin{tabular}{lcclcccc}
\hline & Lv & W & T & Iw & Lv/W & T/L & Iw/W \\
\hline $\mathrm{N}$ & 10 & 10 & 6 & 10 & 10 & 6 & 9 \\
$\mathrm{X}$ & 10.0 & 11.8 & 4.2 & 10.3 & $85.2 \%$ & $47.6 \%$ & $87.9 \%$ \\
$\mathrm{~S}$ & 3.04 & 3.36 & 1.11 & 2.63 & 10.0 & 6.5 & 9.5 \\
$\mathrm{MIN}$ & 5.9 & 7.5 & 2.8 & 6.5 & $70.2 \%$ & $40.0 \%$ & $75.0 \%$ \\
MAX & 14.2 & 18.2 & 5.5 & 13.7 & $103.6 \%$ & $56.3 \%$ & $100.0 \%$ \\
\hline
\end{tabular}

DESCRIPTION. Shell weakly ventribiconvex, slightly transverse, suboval in outline, on average $82 \%(\mathrm{~S}=7.0, \mathrm{~N}=10)$ as long as wide and $48 \%(\mathrm{~S}=6.0, \mathrm{~N}=6)$ as high as long. Anterior commissure slightly shorter than maximum shell width at mid-length. Cardinal extremities obtuse. Anterior commissure rectimarginate or weakly sulcate. Radial ornament costellate with up to 17 primary costae and costellae branching near the mid-length and near the anterior and lateral margins. $6-8$ costellae per $3 \mathrm{~mm}$ along the anterior margin and varying from 31 to 54 in full-grown specimens.

Ventral valve moderately and unevenly convex with maximum thickness at about one-third valve length from the small, pointed beak. Ventral interarea apsacline, slightly curved in cross-section with open, narrow delthyrium. Dorsal valve weakly convex with maximum thickness slightly anterior from the beak. Interarea low, planar, linear. Shallow sulcus usually well defined in the posterior half of the dorsal valve, but fading anteriorly

Ventral interior with small teeth and low, divergent dental plates. Muscle field small, slightly elongate, subpentagonal in outline. Adductor scars narrow, completely separating diductor scars of about equal length. Mantle canals saccate with slightly divergent proximal parts of vascula media. Dorsal valve interior with high, subtriangular brachiophores diverging anteriorly. Cardinal process ridge-like with crenulated myophore, situated on a low subtriangular notothyrial platform. Adductor muscle field subrectangular with anterior adductor scars slightly larger than posterior. Median ridge low and broad, bisecting the entire adductor muscle field.

Discussion. Dolerorthis pristina differs from D. expressa (Popov 1980 ) in its less convex dorsal valve, much smaller size (less than half $D$. expressa), and in its evenly convex ventral profile, in contrast to $D$. expressa in which the ventral profile is relatively flat near the umbo, but increases greatly anteriorly. In addition, $D$. pristina has finer radial ornament.

Zeng (1987) erected Paradolerorthis as a subgenus within Dolerorthis. However, his quoted distinctions and equivocal illustrations do not allow us to recognize his subgenus as useful, but the type species D. (Paradolerorthis) calla appears similar to D. pristina.

\section{Family GLYPTORTHIDAE Schuchert \& Cooper, 1931 Genus GLYPTORTHIS Foerste, 1914}

TYPE SPECIES. Orthis insculpta Hall, 1847, from the Richmondian (Ashgill), New York, U.S.A.

\section{Glyptorthis sp.}

Pl. 10, figs $37-42$

MATERIAL. Five pairs of conjoined valves, 7 ventral and 6 dorsal valves from Samples 620 (BC 57163, 64), 8223a, AnderkenynAkchoku; Sample 8214, Ashchisu River; Samples 2538 (BC 57166-69, 57524), 8256, Kujandysai near Akchoku Mountain; Sample 628 (BC 57165, 57525), east side of Kujandysai; Sample 948, Tesik River.

DESCRIPTION. Shell slightly ventribiconvex, transverse, rounded subrectangular in outline, about $80 \%$ as long as wide. Hinge line slightly narrower than maximum shell width at mid-length. Cardinal extremities slightly obtuse. Anterior commissure varying from slightly sulcate to rectimarginate. Ventral valve moderately convex with maximum thickness at umbo. Interarea moderately high, triangular, planar, catacline, divided by narrow triangular, open delthyrium. Dorsal valve gently convex with maximum thickness at about onequarter valve length from the beak. Dorsal sulcus shallow and narrow, originating at umbo and fading anteriorly. Dorsal interarea low, linear, orthocline. Radial ornament coarsely costellate with up to 16 primary ribs and $25-30$ costellae (up to 5 costellae per $3 \mathrm{~mm}$ ) in adult specimens. Secondary costellae in the median part of the dorsal valve bifurcate internally. Concentric ornament of crowded, evenly spaced growth lamellae.

Ventral interior with teeth supported by short and high dental plates. Muscle field small, situated entirely within delthyrial chamber. Mantle canals saccate with straight, slightly diverging anteriorly vascula media. Dorsal interior not observed.

DisCUSSION. These specimens closely resemble Glyptorthis balcletchiensis (Davidson, 1883) from the Upper Caradoc of the Girvan District, Scotland (Williams 1962) in the size, general outline and convexity of the shell, as well as in the number and bifurcation of the costellae. It differs from another coarsely ribbed Kazakh species Glyptorthis? bestamaki Nikitin \& Popov (in Klenina et al. 1984) from the lower Bestamak Formation (Nemagraptus gracilis Zone) of the Chingiz Range in having a rectimarginate or slightly sulcate anterior commissure and a dorsal sulcus not reversed anteriorly into the median fold.

Family PLAESIOMYIDAE Schuchert, 1913 Genus AUSTINELLA Foerste, 1909

TYPE SPECIES. Orthis kankakensis McChesney, from the Maquoketa Formation (Ashgill) of Iowa, U.S.A.

Austinella sarybulakensis sp. nov.

Pl. 11, figs 15-22

ETYMOLOGY. After Sarybulak River, $10 \mathrm{~km}$ west of the type locality.

HolOtYPE. BC 56507, Pl. 11, figs 15-18, conjoined valves; Anderken Formation, Sample 85258, east side of Uzunbulak River.

MATERIAL. Three conjoined valves, one ventral and one dorsal valve from Sample 85258 (BC 56505-8), east side of Uzunbulak River; Sample 818a, Burultas Valley.

DESCRIPTION. Shell subequally biconvex, transverse, subrectangular in outline about $93-97 \%$ as long as wide and $54-60 \%$ as thick as long. Hinge line somewhat shorter than maximum shell width at the mid-length. Anterior commissure uniplicate. Ornament costellate with $8-9$ costellae per $5 \mathrm{~mm}$ along the anterior margin and 25-28 primary ribs near the umbo. Ventral valve moderately convex with maximum thickness slightly anterior to the umbo. Ventral pseudointerarea high, triangular with open, triangular delthyrium. Shallow sulcus originating at about 7 to $9 \mathrm{~mm}$ anterior to the beak, widening and deepening anteriorly. Lateral sides of the valve gently and evenly convex in transverse section. Dorsal valve moderately and unevenly convex. Dorsal interarea low, planar, orthocline. Shallow dorsal sulcus in the umbonal area reverses into a median fold at 5-7 $\mathrm{mm}$ from the umbo.

Ventral interior with strong teeth and short, slightly divergent dental plates. Muscle field strongly raised anteriorly in a form of pseudospondylium, rounded subtriangular in outline, about two- 

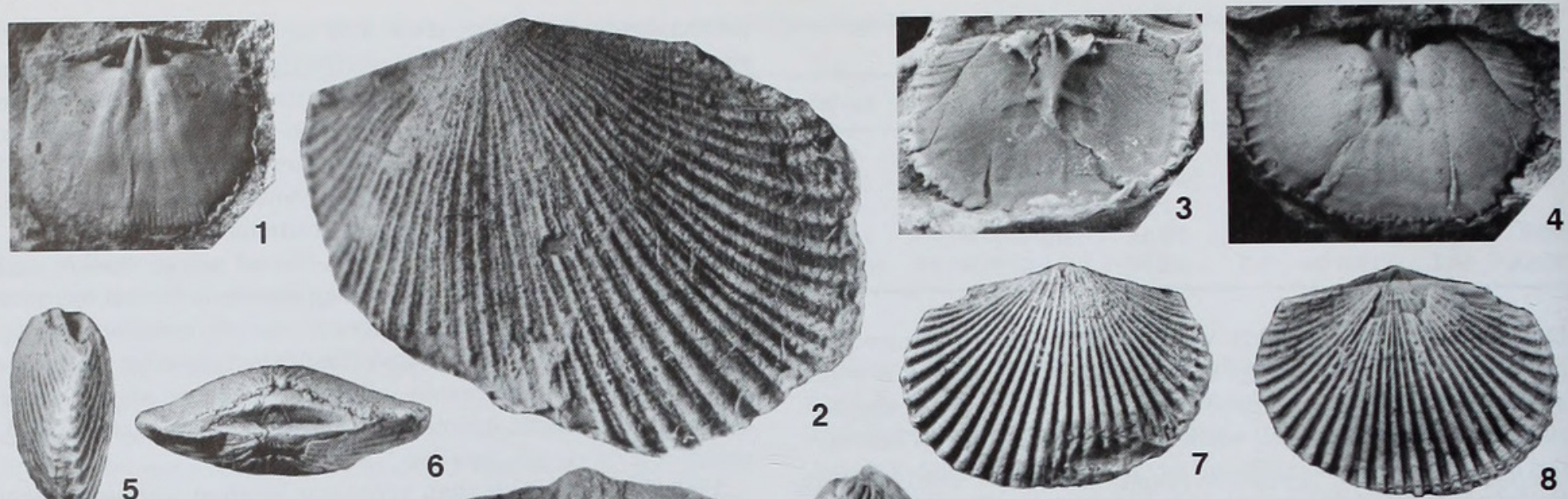

(1) 5
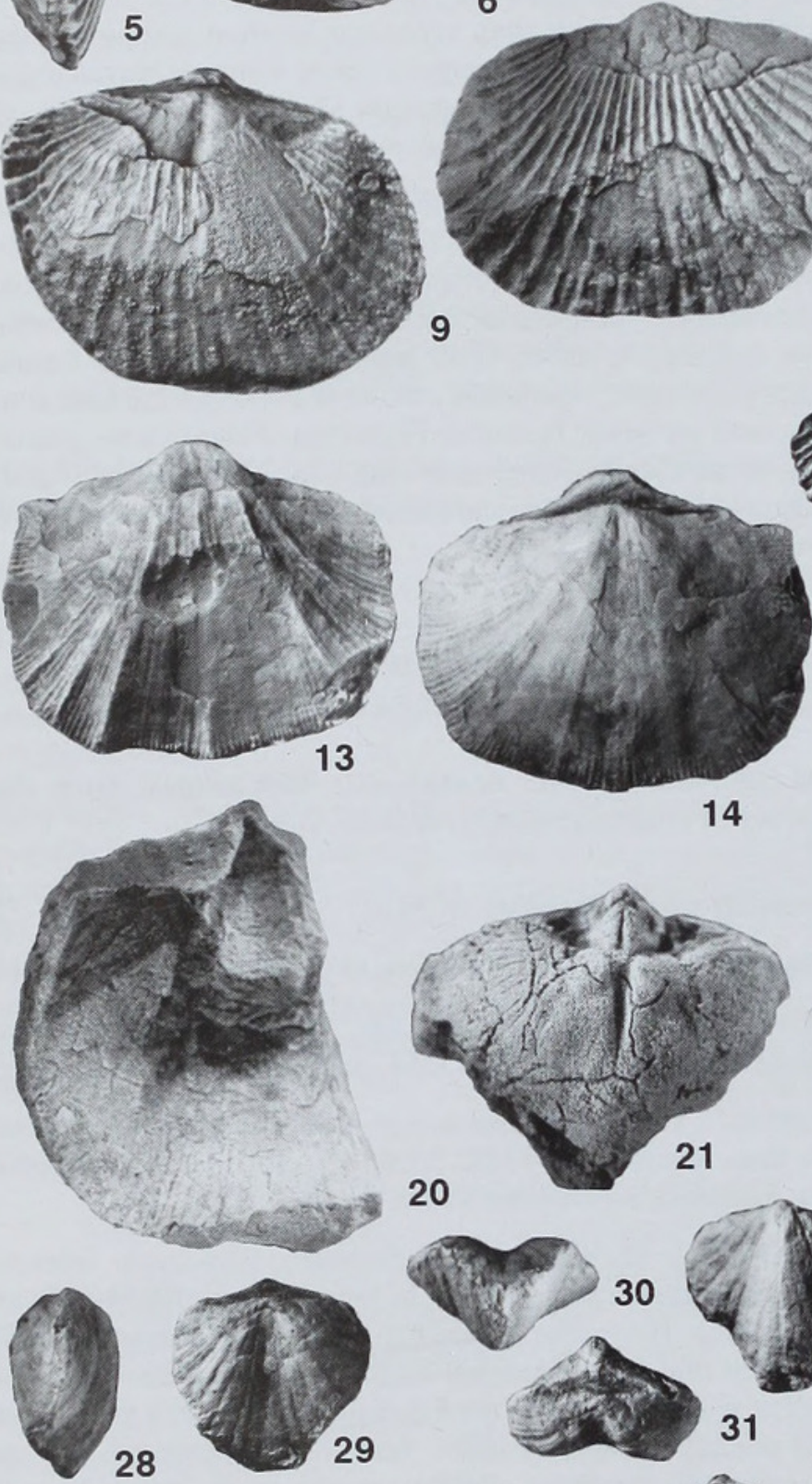

20
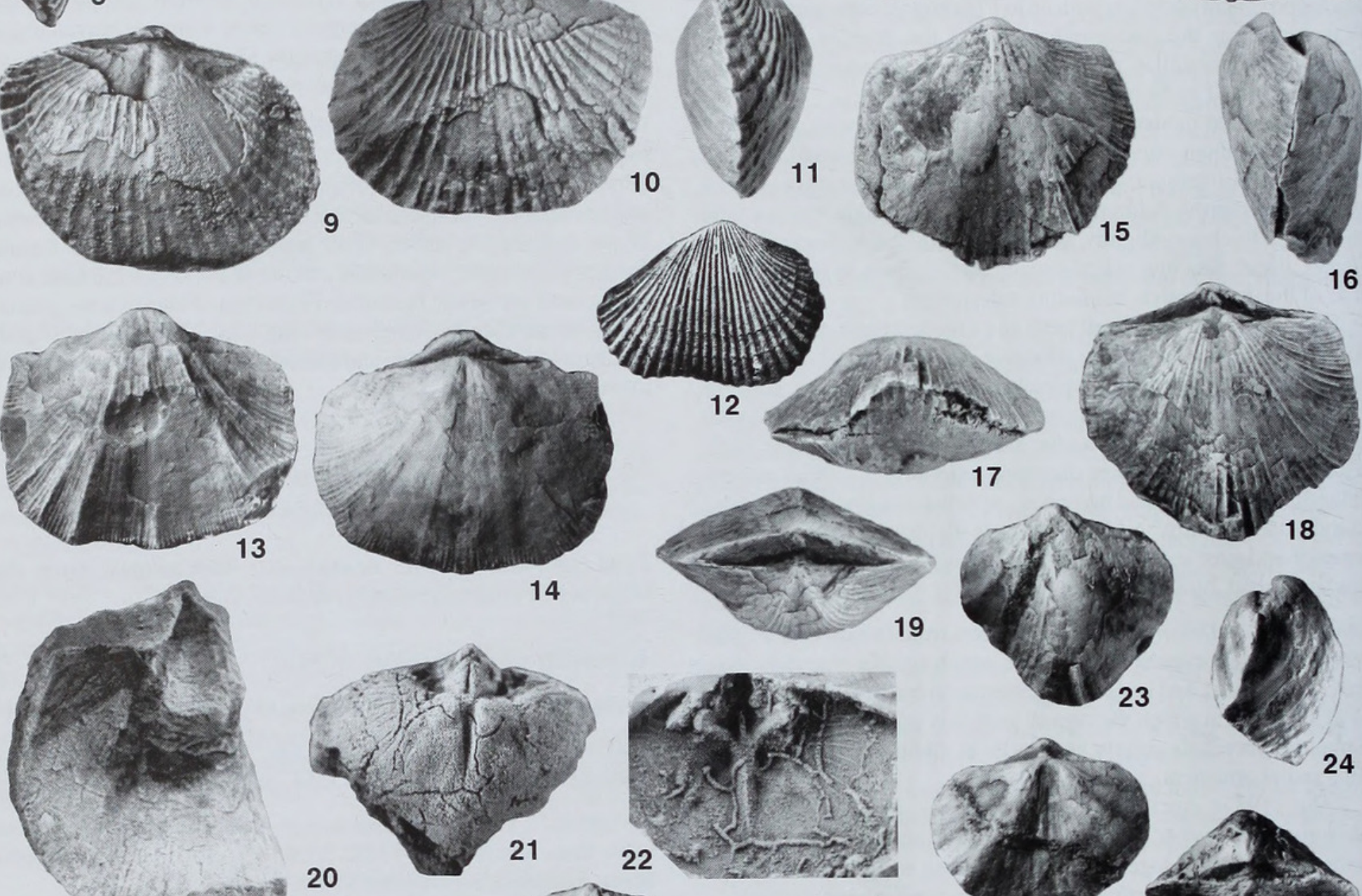

14
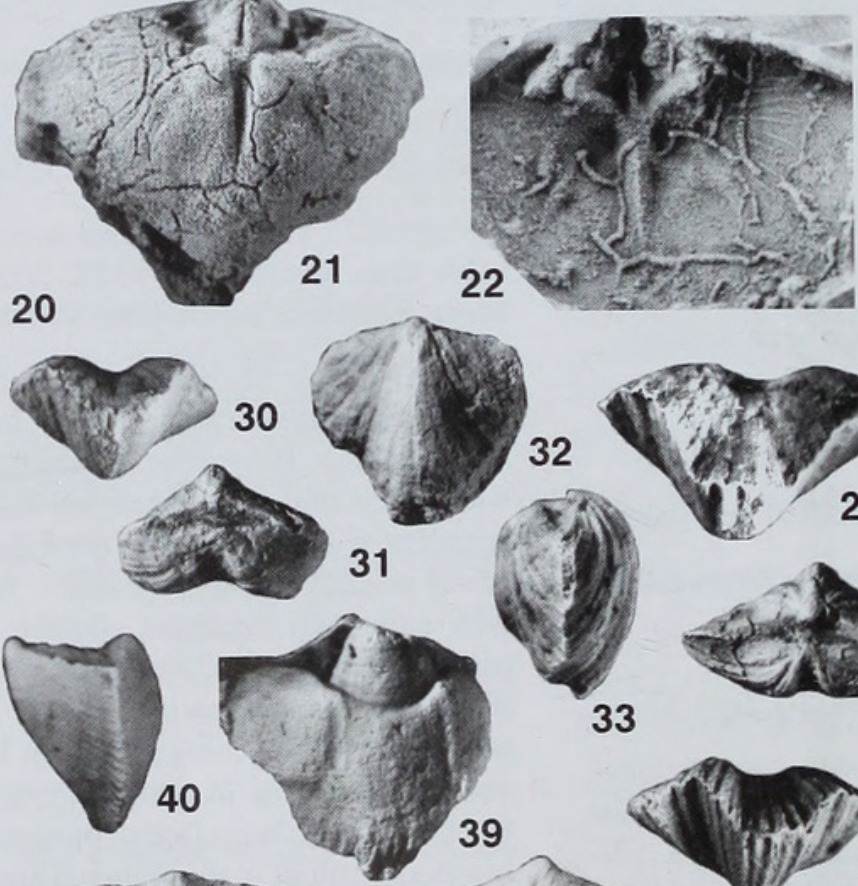

19
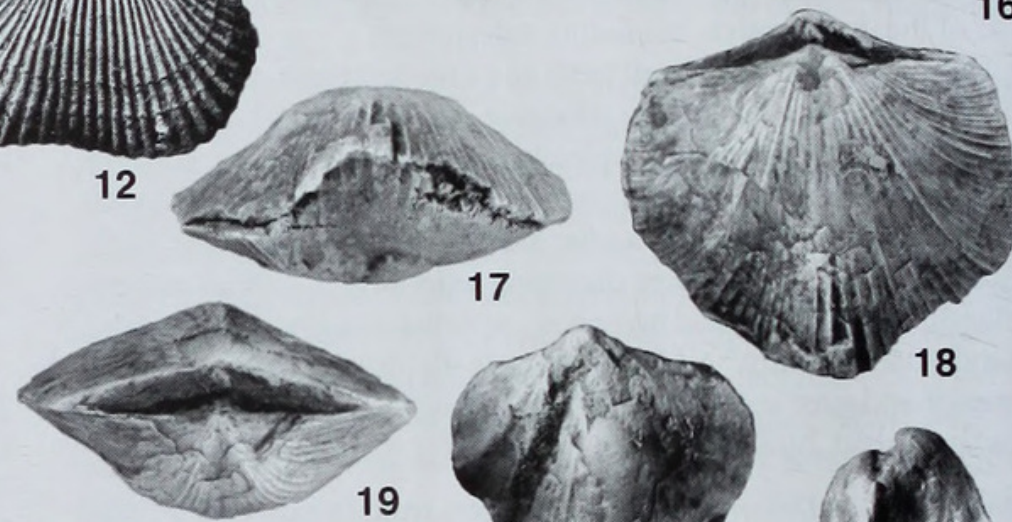

16
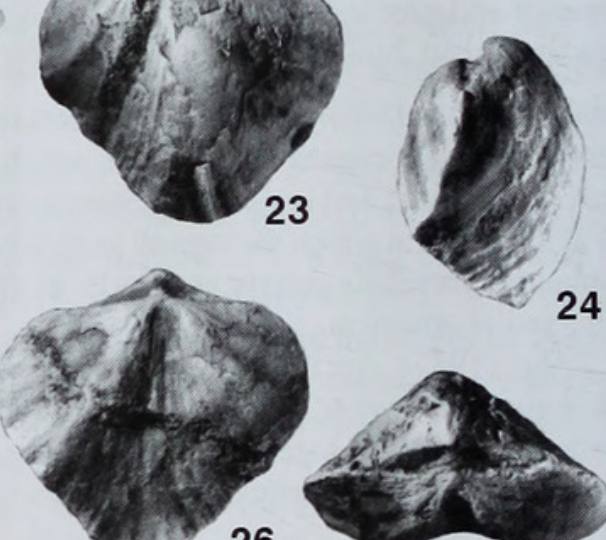

24

26

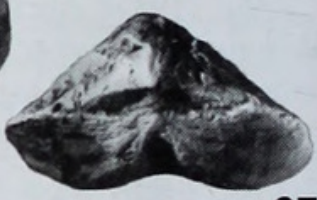

27
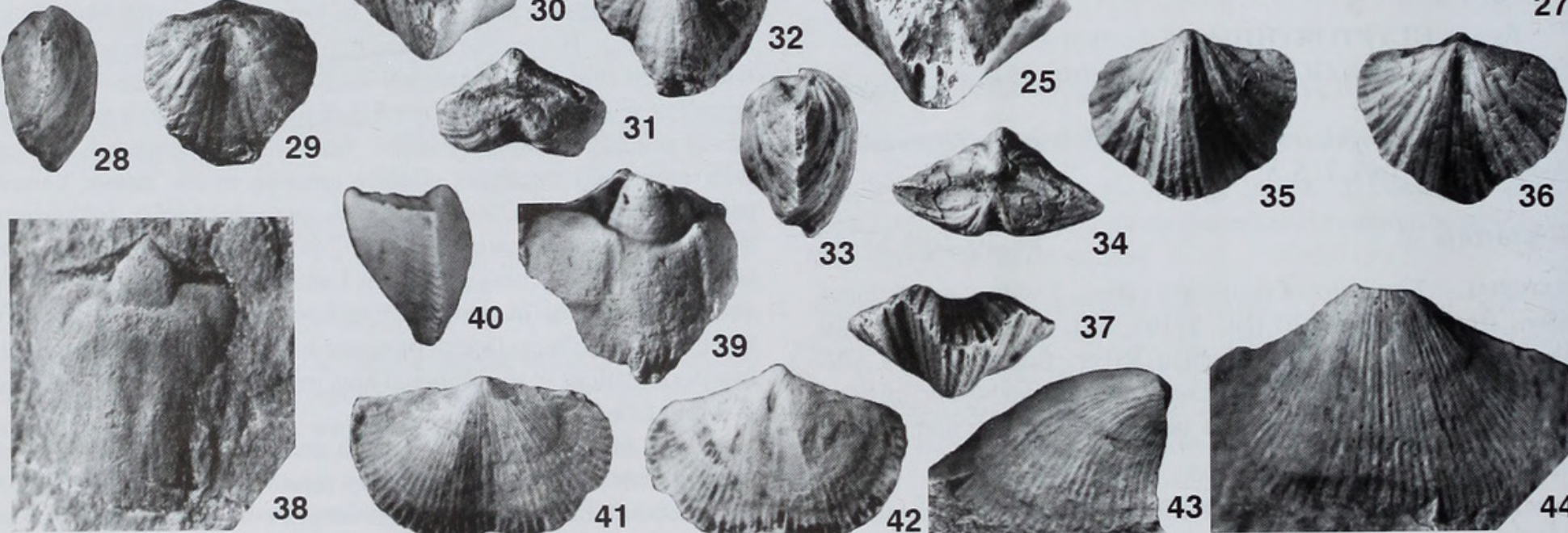

33

34

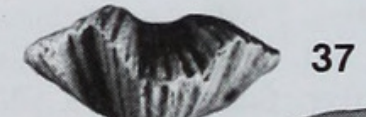
(ij)

82 
fifths as long as the valve. Mantle canal system saccate with short, diverging vascula media. Dorsal interior with blade-like cardinal process situated on a high subtriangular notothyrial platform. Brachiophores high, subtriangular with strongly thickened, slightly divergent bases. Adductor field weakly impressed, quadripartite, bisected by a low median ridge. Anterior adductors larger than posterior ones.

MEASUREMENTS. Conjoined valves; [BC 56507, $\mathrm{L}=22.2, \mathrm{~W}=24.0$, $\mathrm{T}=12.2, \mathrm{Sw}=14.4, \mathrm{St}=6.4 ; \mathrm{BC} 56508, \mathrm{~L}=25.1, \mathrm{~W}=26.3, \mathrm{~T}=14.8$, $\mathrm{Sw}=14.6, \mathrm{St}=6.8]$.

DisCUSSION. This species can be distinguished from other species of the genus such as Austinella whitfieldi (Winchell \& Schuchert) and A. kankakensis (McChesney), re-described by Wang (1949) from the Ashgill Maquoketa Formation of Iowa, by its uniplicate anterior commissure with the dorsal sulcus reversed into the median fold posterior to the mid-valve.

\section{Superfamily PLECTORTHOIDEA Schuchert, 1929 Family PLECTORTHIDAE Schuchert, 1929 Subfamily PLECTORTHINAE Schuchert, 1929 Genus PLECTORTHIS Hall \& Clarke, 1892}

TYPE SPECIES. Orthis plicatella Hall, from the Cincinnatian (Lower Ashgill), of the U.S.A.

Plectorthis? burultasica sp. nov. Pl. 10, fig. 43, Pl. 11, figs 3-12

1985 Plectorthis aff. altaica Severgina; Popov: 51, pl. 1, figs 1, 2.

ETYMOLOGY. After the type locality in the Burultas Valley.

HolotyPE. BC 57528, Pl. 11, figs 3-4, dorsal valve, Anderken Formation, Sample 7613, Akchoku Mountain, Kujundysai section.

MATERIAL. Five conjoined valves, 8 ventral and 9 dorsal valves from Samples 2538, 7613 (BC 57528), Kujandysai near Akchoku Mountain; Sample 626 (BC 57170, 71), 843, 8128 (BC 57530), Anderkenyn-Akchoku; all Chu-Ili Range; Sample 1041a (BC 57529), Burultas Valley; Sample 1018 (BC 57367), 7 km southwest of Karpkuduk well, Kotnak mountains, south Betpak-Dala.

DESCRIPTION. Shell subequally biconvex, transversely subrectangular in outline, about $60 \%$ as thick as long and three-quarters as long as wide, with maximum width at mid-length. Cardinal extremities obtuse to slightly rounded. Anterior commissure rectimarginate. Ventral valve moderately and gently convex in lateral profile with low, strongly apsacline interarea slightly curved in cross-section. Dorsal valve moderately and evenly convex in lateral profile with low, linear, orthocline interarea and shallow umbonal sulcus fading at mid-length. Radial ornament of 28-32 rounded costellae bifurcating at the posterior half of the shell and separated by interspaces of about equal width as ribs. Radial rows of fine rounded exopunctae on both sides of each rib.

Ventral valve with teeth supported by thin diverging dental plates about one-third shorter than length of the elongate subpentagonal muscle field. Adductor scar narrow triangular, slightly raised anteriorly, about the same length as strongly impressed diductor scars. Dorsal valve interior with high, triangular brachiophores with bases converging anteriorly. Notothyrial platform high and narrow, crossed by ridge-like cardinal process with crenulated myophore. Median ridge strong, extending anteriorly to mid-valve. Dorsal anterior and posterior adductor scars about equal size, separated by fine, slightly oblique, transverse ridges.

Discussion. Criteria for generic separation amongst the Plectorthidae require revision. The type species of Plectorthis, $P$. plicatella, has never been fully revised, although Schuchert \& Cooper (1932, pl. 11, figs 4, 9) illustrated ventral and dorsal interiors from the Maysville Formation of Cincinnati, Ohio. Material labelled as $P$. plicatella in the Natural History Museum (eg. BB 14835) from Cincinnati includes well preserved exteriors with no trace of exopunctae. However, our new species has well-developed rows of exopunctae on both sides of each costa, as have other species attributed to Plectorthis, e.g. Plectorthis? punctata illustrated by Cooper (1956), P. obesa, mentioned but not illustrated by Cooper (1956), and the Plectorthis sp. of Neuman (1971:21). Thus, until comparable exopunctae have been found in true $P$. plicatella, we attribute the exopunctate species to Plectorthis with a query.

Plectorthis? burultasica resembles Plectorthis altaica Severgina, 1967 from the Khankhara Formation (Caradoc) of Gornyi Altai in radial ornament, size and outline, but differs in having a weak umbonal dorsal sulcus fading to the mid-valve and a more ventribiconvex profile. Plectorthis? punctata has a slightly sulcate dorsal valve by comparison with $P$ ? burultasica as well as fewer rib bifurcations. It is also considerably smaller. In addition, $P$ ? obesa has a more strongly convex dorsal valve and fewer bifurcations in the ribbing.

\section{PLATE 11}

Figs 1, 2 Dolerorthis expressa Popov, Sample 8137, Anderkenyn-Akchoku section, BC 57526, dorsal internal mould, $\times 2$, and latex of external mould, $\times$ 6.

Figs 3-12 Plectorthis? burultasica sp. nov. 3, 4, Sample 7613, Akchoku Mountain, Kujandysai section. BC 57528, holotype, dorsal latex cast and internal mould, $\times 2$. 5-8, Sample 1041a, Burultas, BC 57529, conjoined valves, lateral, posterior, ventral and dorsal views, $\times 2$. 9-11, Sample 1018, area $7 \mathrm{~km}$ SW of Kotnak mountains, south Betpak-Dala, CNIGR 1/11989, conjoined valves, dorsal, ventral and lateral views, $\times 2$. 12, Sample 8128 , AnderkenynAkchoku section, BC 57530, ventral exterior, latex cast, $\times 2$.

Figs 13, 14 Phaceloorthis? sp. Sample 2538, Akchoku Mountain, Kujandysai section, BC 57531, conjoined valves, ventral and dorsal views, $\times 1.5$.

Figs 15-22 Austinella sarybulakensis sp. nov. Sample 85258, east side of Kujandysai. 15-18, BC 56507, conjoined valves, holotype, ventral, lateral, anterior and dorsal views, $\times 1.5 .19$, BC 56508, conjoined valves, posterior view, $\times 1.5 .20$, BC 56505, ventral interior, $\times 2.21,22$, BC 56506, dorsal internal mould and latex cast, $\times 2$.

Fig. 23-37 Bowanorthis? devexa sp. nov. Sample 2538, Akchoku Mountain, Kujandysai section. 23-27, BC 57532, conjoined valves, holotype, ventral, lateral, anterior, dorsal and posterior views, $\times 3.28-32$, BC 57533, conjoined valves, lateral, dorsal anterior, posterior, and ventral views, $\times 3.33-37$, BC 57534 , conjoined valves, lateral, posterior, ventral, dorsal and anterior views, $\times 3$.

Figs 38-44 Phragmorthis conciliata Popov. 38, Sample 1018, area 7 km SW of Kotnak mountains, south Betpak-Dala, CNIGR 11/11989, ventral internal mould, $\times$ 4. 39, Sample 7613, Akchoku Mountain, Kujandysai section. BC 57535, ventral internal mould, $\times 5$. 40-42, Sample 2538, Akchoku Mountain, Kujandysai section, BC 57536, conjoined valves, lateral, dorsal and ventral views, × 4. 43, 44, Sample 626, Anderkenyn-Akchoku section, BC 57537, ventral exterior and lateral view, $\times 4$. 
Genus PHACELOORTHIS Percival, 1991

TYPE SPECIES. P. decoris Percival, 1991, from the Quondong Limestone (Caradoc) of New South Wales, Australia.

Phaceloorthis? sp.

Pl. 11, figs 13,14

MATERIAL. One pair of conjoined valves (BC 57531) ( $\mathrm{L}=20.8$, $\mathrm{W}=25.6, \mathrm{~T}=9.8$ ) from Sample 2538, Kujandysai, near Akchoku Mountain.

DESCRIPTION. Shell subequally biconvex, transversely subrectangular in outline with hinge line somewhat shorter than maximum shell width at mid-length. Anterior margin rectimarginate. Ventral valve moderately convex in lateral profile with maximum thickness at one-third valve length. Ventral interarea almost orthocline, slightly curved in cross-section with open, narrow triangular delthyrium. Dorsal valve moderately convex with maximum thickness near the mid-valve. Umbonal area with shallow sulcus fading towards midvalve. Dorsal interarea anacline, planar, linear. Shell surface with 9 low, angular radial plications and sumperimposed finely fascicostellate ribs 7-9 per $3 \mathrm{~mm}$ along the anterior margin. Interior of both valves unknown.

DisCUSSION. The interior of this species remains unknown, which makes its generic attribution highly provisional, but there are only a few impunctate mid and late Ordovician orthide genera with fascicostellate ornament and they are mostly related to the family Giraldiellidae. Otherwise fascicostellate ribbing is characteristic of the plectorthid genus Phaceloorthis. This single specimen somewhat resembles Phaceloorthis recondita Popov, Nikitin \& Cocks, 2000 from the Otar Member (Upper Caradoc) of the Dulankara Moutains in its general shell shape and size and fascicostellate ornament, but differs in having an orthocline ventral interarea and weak radial plications.

Family WANGYUIIDAE Zeng, 1989

Genus BOWANORTHIS Percival, 1991

TYPE SPECIES. Bowanorthis fragilis Percival, 1991, from the Caradoc of New South Wales, Australia.
Bowanorthis? devexa sp. nov. Pl. 11, figs 23-37; Fig. 14

ETYMOLOGY. After devexus, Latin - hollow.

HolotyPe. BC 57532, Pl. 11, figs 23-27, conjoined valves, from the Anderken Formation, Sample 2538, Kujandysai, near Akchoku Mountain.

MATERIAL. Twelve conjoined valves from Samples 2538 (BC 57178, 57532-34), 8217 (BC 57179) Kujandysai, near Akchoku Mountain; Sample 948 (BC 57172-77), Tesik River.

DESCRIPTION. Shell ventribiconvex, slightly transverse and semioval, about $85-98 \%$ as long as wide with hinge line slightly shorter than maximum width at one-quarter shell length. Anterior commissure sulcate. Ventral valve carinate posteriorly, strongly convex in lateral profile with maximum thickness at about one-third valve length. Beak small, erect. Ventral interarea apsacline, incurved in cross-section, with small subtriangular delthyrium. Ventral median fold originating at the umbonal area with steep lateral slopes flanked by folds. Lateral sides of the valves less convex. Dorsal valve evenly convex with linear, anacline interarea and deep, V-shaped median sulcus originating at the beak and ending in a low semioval tongue occupying slightly less than half of the valve length. Radial ornament fascicostellate with three strong angular ribs and 4-5 costellae per mm along the anterior margin of mature specimens. Interior of both valves unknown.

Measurements. Conjoined valves; (58/12375) $\mathrm{L}=6.4, \mathrm{~W}=6.7$, $\mathrm{T}=3.8, \mathrm{Sw}=3.3 ;(59 / 12375), \mathrm{L}=4.5, \mathrm{~W}=4.6, \mathrm{~T}=2.7, \mathrm{Sw}=2.6 ;(60$ / 12375), $\mathrm{L}=4.8, \mathrm{~W}=5.6, \mathrm{~T}=3.1, \mathrm{Sw}=2.4$.

DISCUSSION. This species is provisionally included within Bowanorthis because of the small ventribiconvex shell with strongly sulcate anterior commissure, carinate ventral valve, fascicostellate ornament and receding dental plates, all resembling $B$. fragilis from the Caradoc of New South Wales (Percival 1991); however, it differs in having a strongly apsacline ventral interarea and a less transverse shell outline. The general morphology of the cardinal process and brachiophores in the Kazakh species looks similar to B. fragilis, but the presence of the characteristic sigmoidal plates is impossible to
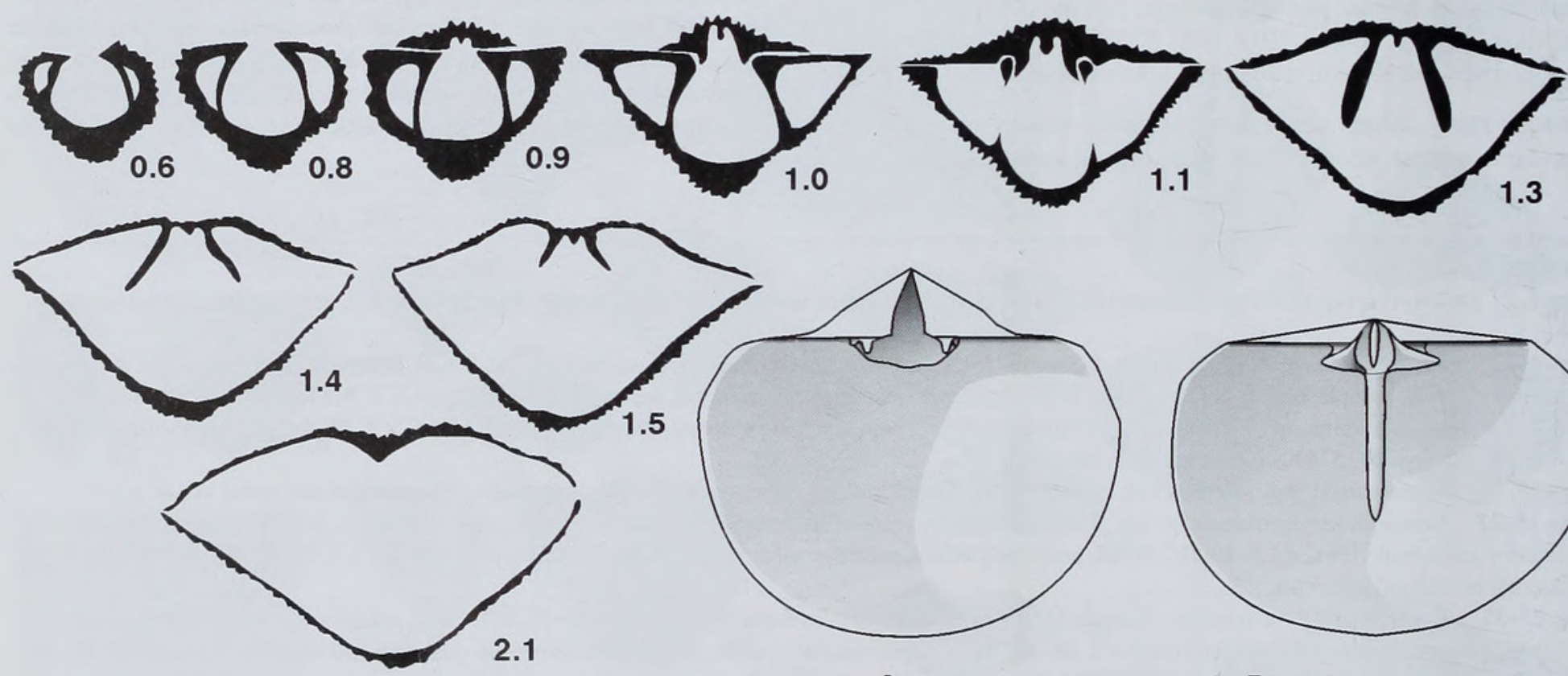

0

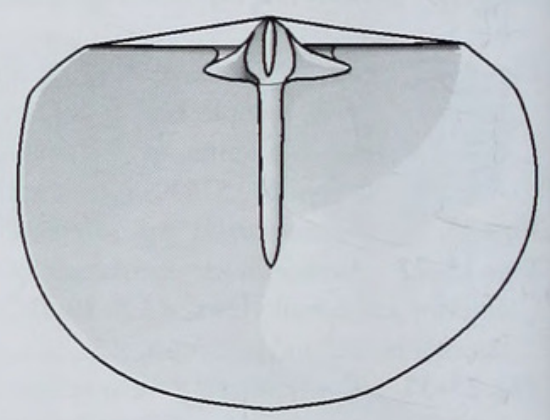

$5 \mathrm{~mm}$

Fig. 14 Transverse serial sections of Bowanorthis? devexa sp.nov. from Sample 2538, Kujandysai section. Distance in mm is measured from the posterior tip of ventral beak. Dorsal valve uppermost. Also reconstructions of the ventral and dorsal interiors. 
confirm from our sections (Fig. 14). In general shell shape and fascicostellate radial ornament the Anderken material is similar to Ranorthis Öpik (1939) from the Volkhov and Kunda Stages of Baltica. However, the generic attribution of devexa is tentative and it may represent an undescribed genus.

\section{Family RANORTHIDAE Havlí̌ek, 1949}

Genus EODALMANELLA Havlíłek, 1950

TYPE SPECIES. Orthis socialis Barrande, 1879; from the Sarká Formation (Llanvirn) of Bohemia.

\section{Eodalmanella extera Popov, 1985 Pl. 12, figs 10-12, 15}

1985 Eodalmanella extera Popov: 54, pl. 1, figs 3-8.

HoLOTYPE. CNIGR 4/11989, ventral internal mould ( $\mathrm{L}=4.1$, $\mathrm{W}=6.1$ ), from the Anderken Formation, Anderkenyn-Akchoku section, Sample 843.

MATERIAL. Five pairs of conjoined valves, 42 ventral and 48 dorsal valves, internal and external moulds, from Samples 100b, 620 (BC 57189), 843, Anderkenyn-Akchoku section; Sample 1018, 7 km southwest of Karpkuduk well, Kotnak Mountains.

DESCRIPTION. Shell ventribiconvex, transverse, subrectangular in outline, about $85 \%$ as wide as long with maximum width at midlength. Anterior commissure gently sulcate. Ventral profile moderately convex, about one-third as thick as long, with maximum thickness at about one-quarter valve length. Dorsal valve gently convex in transverse profile with maximum thickness slightly anterior to the umbo and with shallow median sulcus originating in the umbonal area. Dorsal interarea linear, strongly anacline. Radial ornament multicostellate with 3-6 ribs per mm along the anterior margin of mature specimens. Concentric ornament of very fine ridge-like, evenly spaced fila, often branching anteriorly.

Ventral interior with teeth supported by short, divergent dental plates and rounded subtriangular, slightly elongate muscle field about $37 \%$ as long as the valve. Ventral adductor scars narrow, subtriangular, slightly shorter than diductor scars. Cardinal process ridge-like with bilobed, crenulated miophore. Brachiophores high, triangular, with widely diverging bases. Fulcral plates well developed. Dorsal adductor scars quadripartite, extending anteriorly to mid-valve, bordered laterally by low ridges.

DisCUSSION. This species strongly resembles Scaphorthis? aulacis Percival (1979a) from the Caradoc Goonumbla Volcanics of New South Wales in the impunctate shell, radial ornament and internal morphology of both valves. The Kazakh species differs in having longer dental plates, a cardinal process with a long shaft crossing all the bottom of the notothyrial cavity and well defined lateral ridges bordering the dorsal adductor field. A detailed discussion and basic statistics of this species were provided by Popov (in Nikitin \& Popov 1985).
Family CREMNORTHIDAE Williams, 1963

Genus PHRAGMORTHIS Cooper, 1956

TYPE SPECIES. Phragmorthis buttsi Cooper, 1956, from the EffnaRich Valley Formations (Llandeilo-Lower Caradoc) of Virginia, U.S.A.

\section{Phragmorthis conciliata Popov, 1985 \\ Pl. 11, figs 38-44; Pl. 12, figs 1-9}

1985 Phragmorthis conciliata Popov: 52, pl. 1, figs 9-12.

HolotyPe. CNIGR 10/11989 (Pl. 12, figs 1, 2), dorsal valve internal mould ( $\mathrm{L}=4.5, \mathrm{~W}=7.2$ ), from the Anderken Formation, $7 \mathrm{~km}$ south-west of Karpkuduk well, Kotnak Mountains, Sample 1018.

MATERIAL. Two pairs of conjoined valves, 6 ventral and 8 dorsal valves, internal and external moulds, from Samples 626 (BC 57537), 8223a, Anderkenyn-Akchoku section; Samples 2538 (BC 57536), 7613 (BC 57535), Kujandysai section; Sample 8230, BuldukbaiAkchoku section; Sample 1018, 7 km southwest of Karpkuduk well Kotnak Mountains; Sample 1024b, south side of Karatal River, south of Sorbulak spring.

DiAGNOSIS. Shell ventribiconvex, transverse, subrectangular outline about $77 \%$ as wide as long with maximum width at mid-length, anterior commissure gently unisulcate; ventral valve strongly convex with maximum thickness between the umbo and mid-valve; ventral interarea high triangular, apsacline with narrow open delthyrium; dorsal valve moderately and evenly convex with narrow and shallow sulcus originating at the umbo; radial ornament finely and equally multicostellate with 5 ribs per $\mathrm{mm}$ along the anterior margin of mature specimens. Ventral interior with elongate subtriangular muscle field on pseudospondylium $21-26 \%$ as long as the valve. Dorsal interior with simple, ridge-like cardinal process on the high notothyrial platform which is strongly raised anteriorly; high, blade-like median septum $88 \%$ valve length; large, deeply impressed adductor scars, radially arranged, about $66 \%$ valve length.

Discussion. This species differs from Phragmorthis buttsi Cooper (1956: 510) in its transverse subrectangular outline and lesser convexity of both valves. It is on average about half the size of Phragmorthis crassa Cooper (1956: 511) and has finer radial ornament. Both $P$. buttsi and $P$. crassa have a subcarinate ventral valve, which is another difference from the Kazakh species.

Table 21 Measurements of ventral valves of Pionodema opima sp. nov., Sample 8228 from Kopalysai Section, sample 8230 from BuldukbaiAkchoku and Sample 7613 from Kujandysai section.

\begin{tabular}{lllllccc}
\hline & Lv & W & Ml & Mw & Lv/W & Ml/L & Iw/W \\
\hline $\mathrm{N}$ & 9 & 9 & 5 & 6 & 9 & 5 & 5 \\
$\mathrm{X}$ & 7.6 & 9.4 & 3.2 & 3.5 & $81.2 \%$ & $38.5 \%$ & $90.5 \%$ \\
$\mathrm{~S}$ & 1.38 & 2.16 & 0.63 & 1.26 & 8.6 & 4.9 & 14.9 \\
MIN & 5.0 & 7.3 & 2.6 & 2.3 & $68.5 \%$ & $34.2 \%$ & $64.9 \%$ \\
MAX & 9.8 & 13.8 & 4.1 & 5.7 & $93.2 \%$ & $46.6 \%$ & $103.6 \%$ \\
\hline
\end{tabular}

Table 22 Measurements of dorsal valves of Pionodema opima sp. nov., Sample 8228 from Kopalysai Section, sample 8229 from Buldukbai-Akchoku and Sample 7613 from Kujandysai section.

\begin{tabular}{|c|c|c|c|c|c|c|c|c|c|}
\hline & $\mathrm{Ld}$ & W & $\mathrm{BBl}$ & $\mathrm{BBw}$ & Ml & $\mathrm{Mw}$ & $\mathrm{Lv} / \mathrm{W}$ & $\mathrm{Ml} / \mathrm{L}$ & $\mathrm{BBw} / \mathrm{W}$ \\
\hline $\mathrm{N}$ & 7 & 7 & 5 & 5 & 3 & 3 & 4 & 3 & 5 \\
\hline$X$ & 7.6 & 9.5 & 1.6 & 2.6 & 3.4 & 3.1 & $82.8 \%$ & $41.2 \%$ & $60.4 \%$ \\
\hline S & 2.36 & 2.86 & 0.15 & 0.34 & 0.32 & 0.10 & 10.7 & 2.9 & 9.9 \\
\hline MIN & 3.2 & 4.0 & 1.4 & 2.3 & 3.2 & 3.0 & $70.1 \%$ & $38.8 \%$ & $50.0 \%$ \\
\hline MAX & 10.5 & 12.9 & 1.7 & 3.1 & 3.8 & 3.2 & $96.1 \%$ & $44.4 \%$ & $73.9 \%$ \\
\hline
\end{tabular}


Suborder DALMANELLIDINA Moore, 1952

Superfamily ENTELETOIDEA Waagen, 1884

Family DRABOVIIDAE Havlícek, 1950

Subfamily DRABOVIINAE Havlícek, 1950

Genus PIONODEMA Foerste, 1912

TYPE SPECIES. Orthis subaequata Conrad, from the Caradoc of Missouri, U.S.A.

\section{Pionodema opima sp. nov. Pl. 12, figs 13, 14, 16-27}

ETYMOLOGY. After opimus, Latin - fat.

HoLOTYPE. BC 57545, Pl 12, figs 17-18, internal mould of conjoined valves, from the Anderken Formation, Sample 7613, Kujandysai section.

MATERIAL. Nine pairs of conjoined valves, 70 ventral and 64 dorsal valves from Sample 7613 (BC 57545), Kujandysai section; Sample 8128, Anderkenyn-Akchoku; Sample 8228 (BC 57185, 57547, 48), east side of Kopalysai; Samples 110, 8229 (BC 57546), 8230 (BC 57803), 8257 (BC 57544), Buldukbai-Akchoku section; Sample 818a (BC 57802), Burultas Valley.

DESCRIPTION. Shell slightly dorsibiconvex, transverse, suboval in outline, about $84 \%$ as long as wide and $53 \%$ as thick as long. Hinge line slightly shorter than the maximum shell width at mid-length. Anterior commissure uniplicate. Ventral valve gently convex with maximum thickness at the umbonal area. Beak curved, pointed and slightly erect posterior to hinge line. Ventral interarea subtriangular, apsacline, weakly curved in cross-section, with open triangular delthyrium. Shallow sulcus originating near mid-valve. Dorsal valve moderately convex with maximum thickness at quarter valve length. Umbonal area with shallow V-shaped sulcus reversed into a low and narrow median fold flanked laterally by weak plications. Radial ornament multicostellate with 28-30 primary ribs and about 3-5 costellae per mm along the anterior margin of full grown specimens. Growth lines fine, ridge-like, crowded, evenly spaced.

Ventral interior with teeth and long, diverging dental plates continuing into ridges bordering laterally slightly elongate suboval muscle field. Ventral adductor scars narrow and subtriangular, raised anteriorly and somewhat shorter than the strongly impressed elongate suboval diductor scars. Ventral mantle canals lemniscate, straight, widely diverging. Dorsal interior with high, triangular brachiophores with slightly diverging bases. Fulcral plates variably developed. Cardinal process ridge-like with crenulated myophore. Dorsal adductor scars bisected by fine median ridge and bordered laterally by subparallel ridges starting from the ends of the brachiophore bases.
DISCUSSION. This species is characterised by a uniplicate anterior commissure with low dorsal median fold and shallow ventral sulcus, which is unusual for Pionodema (Cooper 1956), and can be compared only with $P$. uniplicata Cooper, but differs from that species in its more transverse outline and the weak umbonal dorsal sulcus reversing into a median fold at about mid-length. The Anderken specimens also lack the prominent ridge anterior to the ventral muscle field of $P$. uniplicata (Cooper 1956: pl. 154, figs $31-32)$.

Order PENTAMERIDA Schuchert \& Cooper, 1931 Suborder SYNTROPHIIDINA Ulrich \& Cooper, 1936 Superfamily CAMARELLOIDEA Hall \& Clarke, 1894 Family CAMARELLIDAE Hall \& Clarke, 1894 Genus PARASTROPHINA Schuchert \& LeVene, 1929

TYPE SPECIES. Atrypa haemiplicata Hall, 1847, from the Trenton Limestone (Caradoc), New York, U.S.A.

Parastrophina iliana sp. nov.

Pl.13, figs 30-50; Figs 15, 16

1956 Camerella haemiplicata (Hall) var. rotunda (Winchell \& Schuchert); Rukavishnikova: 129, pl. 2, figs 1, 3 (non fig. 2).

1975 Parastrophina haemiplicata (Hall); Sapelnikov \& Rukavishnikova: 25, pl. 1, figs 1-8.

1986 Parastrophina haemiplicata (Hall); Kolobova \& Popov; pl. 1, fig. 4 .

HolOTYPE. BC 57557, Pl. 13, figs 38-42, conjoined valves from Sample 100, Anderkenyn-Akchoku section.

MATERIAL. 52 pairs of conjoined valves, one ventral and 3 dorsal valves from Samples 100 (=K-98/1970) (BC 56643-46, 57557), 626 (BC 56634-6), Anderkenyn-Akchoku section; Samples, 628 (BC 56633, 56642, 57559), 2538 (BC 56637-41), 8217 (BC 57556), 8256 (BC 57558), 85258, Kujandysai Section; Sample 948 (BC 57192-99), Tesik River; Sample 1041a, Burultas Valley.

DESCRIPTION. Shell dorsibiconvex to biconvex, transverse, semielliptical in outline, about $90 \%$ as long as wide and $75 \%$ as thick as long. Anterior commissure uniplicate. Ventral valve gently convex with maximum thickness somewhat posterior to mid-valve. Sulcus originating about 5-6 $\mathrm{mm}$ from the umbo, deepening anteriorly and terminating in broad, semioval tongue

\section{PLATE 12}

Figs 1-9 Phragmorthis conciliata Popov. 1, 2, Sample 1018, area 7 km SW of Karpkuduk well, Kotnak Mountains, CNIGR 10/11989, holotype, latex cast and dorsal internal mould, $\times$ 4.3, 5-9, Sample 2538, Akchoku Mountain, Kujandysai section; 3, BC 57538, dorsal exterior, × 4; 5-8, BC 57539, conjoined valves lateral, dorsal, posterior and ventral views, $\times 4 ; 9$, CNIGR $12 / 11989$, latex cast of dorsal exterior, $\times 4.4$, Sample, 8230, BuldukbaiAkchoku section, west side of Kopalysai, BC 57603, dorsal internal mould, $\times 5$.

Figs 10-12, 15 Eodalmanella extera Popov. 10, Sample 1018, area 7 km SW of Karpkuduk well, Kotnak Mountains, CNIGR 9/11989, ventral exterior, $\times$ 4. 11, Sample 620, Anderkenyn-Akchoku section, BC 57189, dorsal exterior latex cast, $\times 5.12$, 15, Sample 843, Anderkenyn-Akchoku section; 12, CNIGR 5/11989, dorsal internal mould, $\times 4$; 15, CNIGR 3/11989, ventral internal mould, $\times 4$.

Figs 13, 14, 16-27 Pionodema opima sp. nov. 13, 14, Sample 8257, Buldukbai-Akchoku section, west side of Kopalysai, BC 57544, internal mould, dorsal and ventral views, $\times 3$. 16, Sample 8230, east side of Kopalysai, BC 57803, latex cast of dorsal external mould, $\times 2.7 .17$, 18, Sample 7613, Akchoku Mountain, Kujandysai section, BC 57545, holotype, internal mould of conjoined valves, dorsal and ventral views, $\times 3$. 19-24, Sample 818 a, Burultas valley, BC 57802, conjoined valves, detail of radial ornament, $\times 8$, and lateral, ventral, dorsal, posterior and anterior views, $\times 4.25$, Sample, 8229, Buldubai-Akchoku section, west side of Kopalysai, BC 57546, dorsal internal mould, $\times 3$. 26, 27, Sample 8228, east side of Kopalysai; 26, BC 57548, ventral internal mould, $\times 3 ; 27$, BC 57547, ventral internal mould, $\times 2$.

Figs 28-35 Ilistrophina tesikensis gen. et sp. nov., Sample 948, Tesik River. 28-31, BC 56824, conjoined valves, lateral, anterior, ventral and dorsal views, $\times 4$. 32-35, BC 56823, conjoined valves, holotype, dorsal, ventral, lateral and anterior views, $\times 4$. 

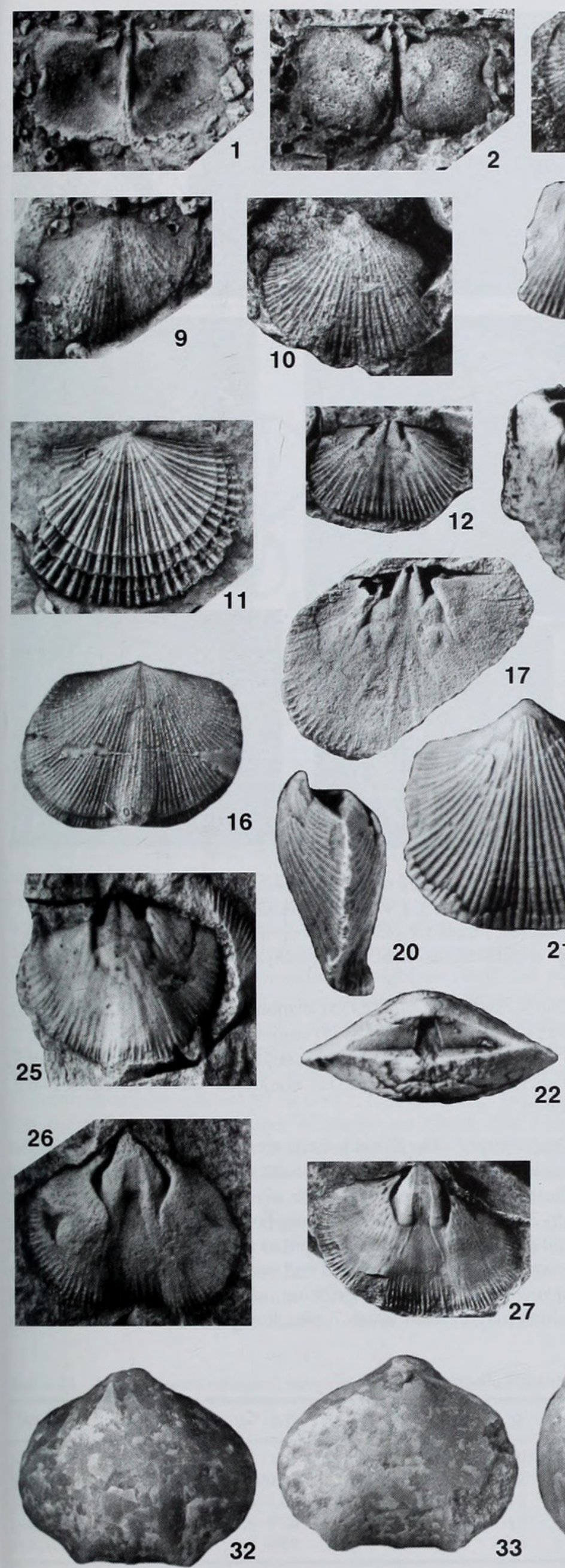
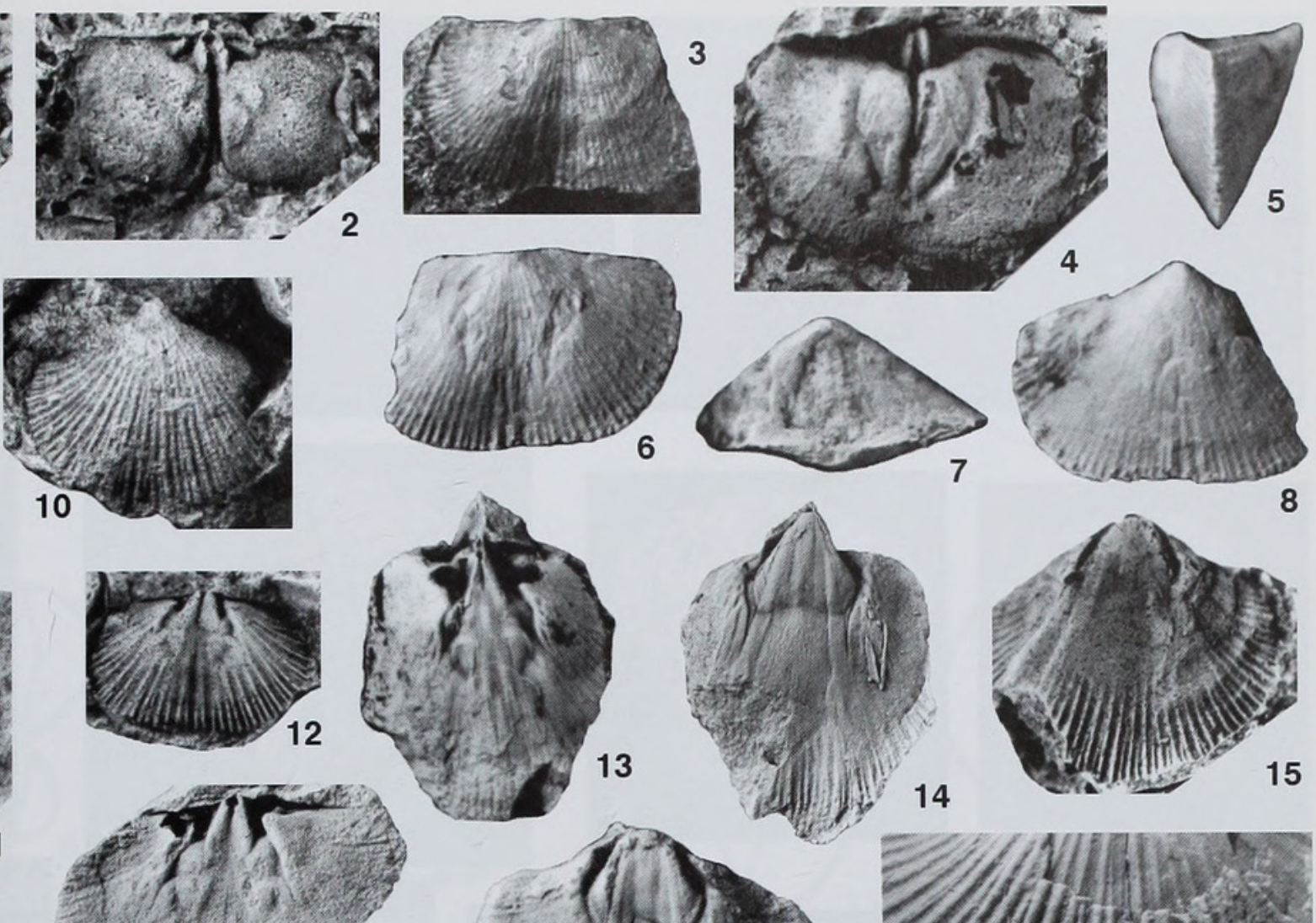
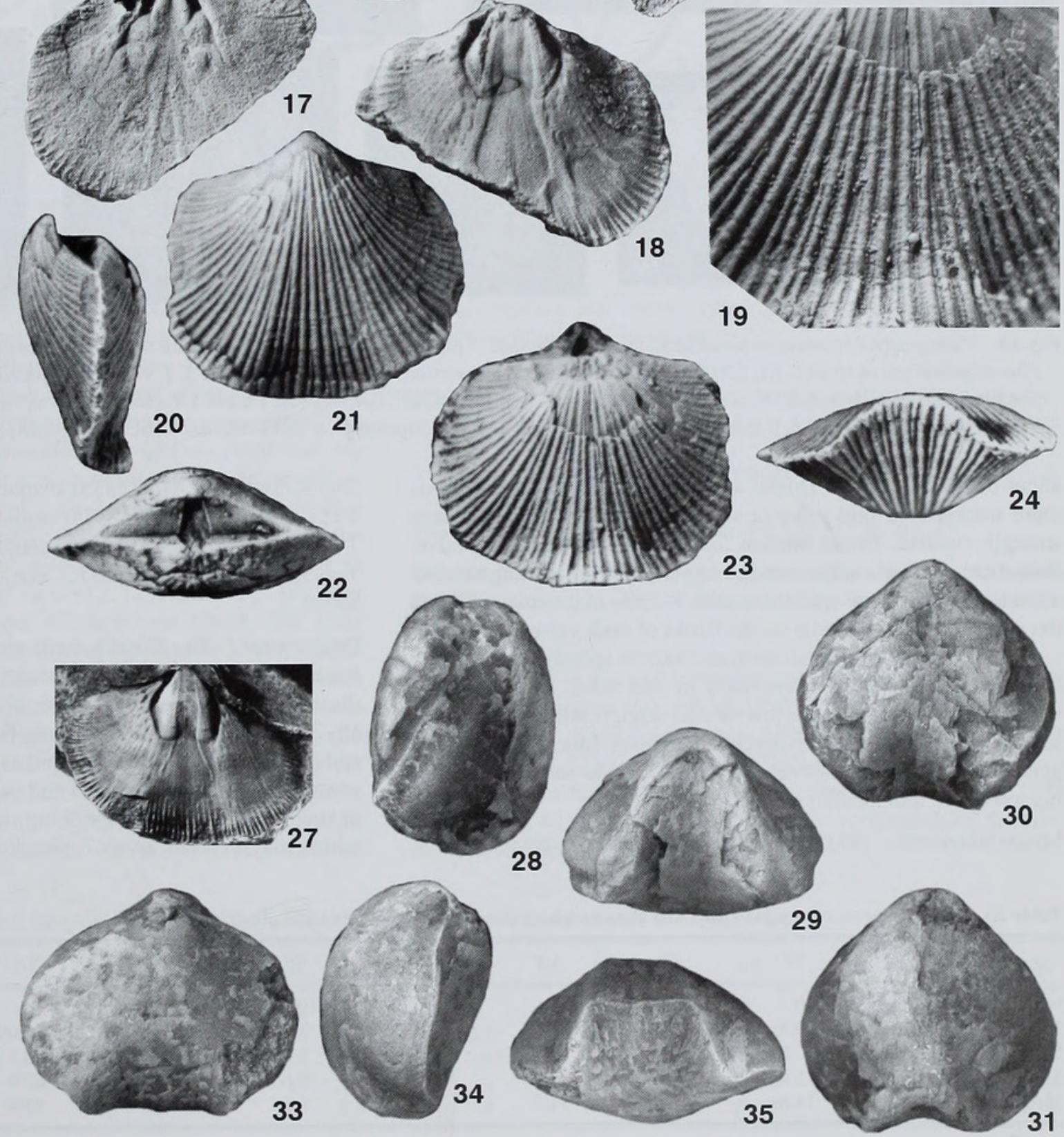

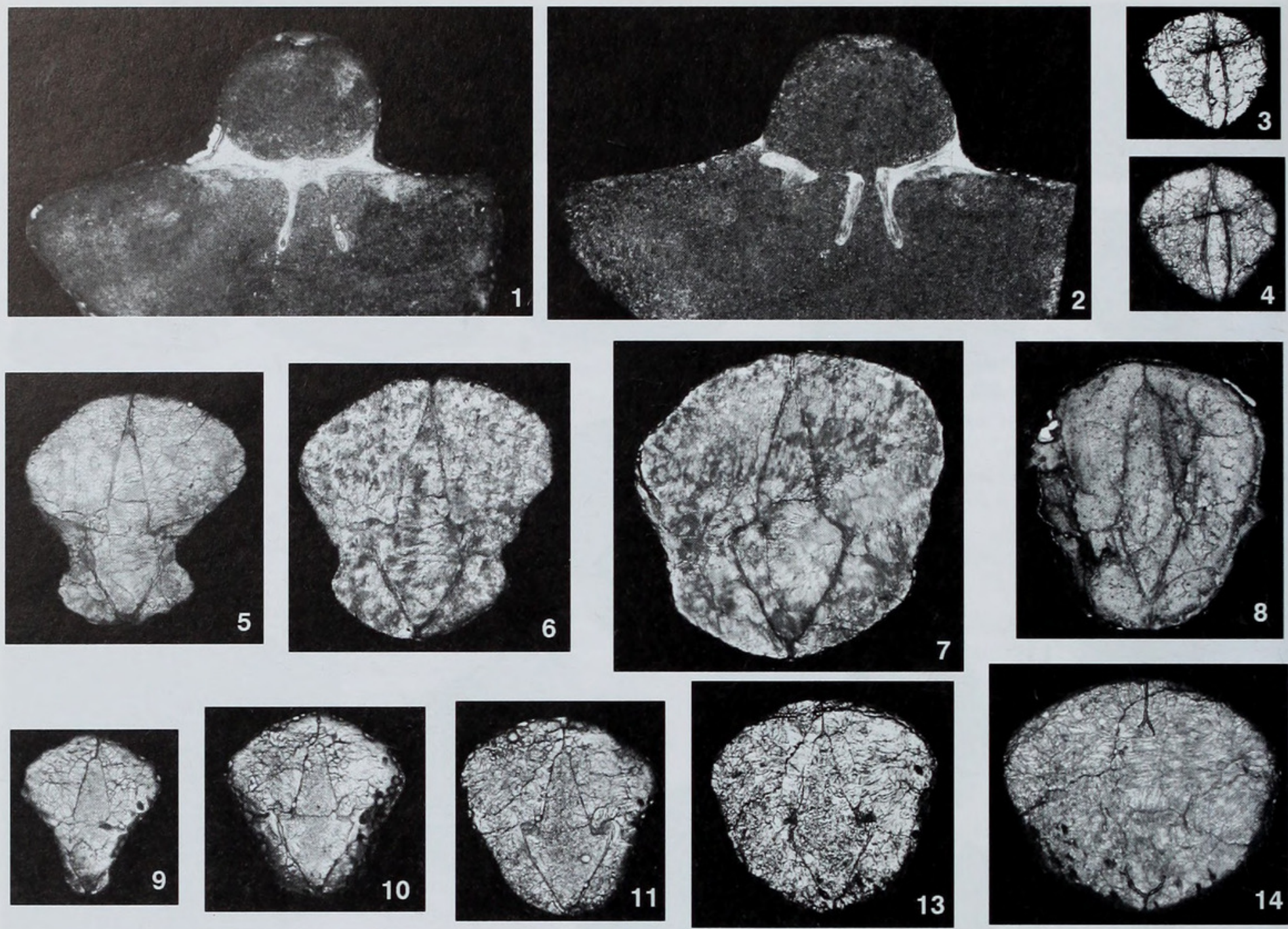

Fig. 15 Photographs of transverse serial sections, $\times 12$. Distance in $\mathrm{mm}$ is measured from the posterior tip of ventral beak. Dorsal valve uppermost. 1-2, Placotriplesia spissa sp.nov., BC 57605, Sample 628, Kujandysai section; 1, 1.5 mm; 2, 1.8 mm. 3, 4, 9-14, Ilistrophina tesikensis gen. et sp. nov., Sample 948, Tesik River, 3,4, BC 57606, 0.3 and 0.4 mm; 9-14, BC 57607, 0.4, 0.6, 0.8, 1.0 and 1.4 mm; 5-7, Parastrophina iliana sp. nov., BC 56560, Sample 948, Tesik River; 0.6, 0.8 and 1.2 mm; 8, Parastrophina plena Sapelnikov \& Rukavishnikova, BC 57564, Sample 948, Tesik River, 1.0 mm.

about $66 \%$ valve width. Dorsal valve strongly convex with maximum thickness at mid-valve or slightly anteriorly. Umbonal area strongly swollen. Broad median fold originating near mid-valve. Radial ornament of coarse rounded-angular ribs originating anterior to mid-valve in mature specimens with 1-3 ribs in the sulcus, 2-4 on the median fold and up to 6 on the flanks of both valves.

Ventral interior with small teeth and narrow spondylium on a low median septum extending anteriorly to mid-valve. Dorsal interior with narrow cruralium on the low median septum. Alate plates small, projecting anteriorly as short brachial processes. Inner plates narrow, gently curved. Outer plates nearly straight in cross-section, converging towards a thin median septum.

MEASUREMENTS. (471/12375) conjoined valves, $\mathrm{L}=14.0, \mathrm{~W}=16.9$,
$\mathrm{T}=6.3, \mathrm{Sw}=8.9 ;(474 / 12375)$ conjoined valves, $\mathrm{L}=20.4, \mathrm{~W}=21.0$, $\mathrm{T}=11.2, \mathrm{Sw}=8.7 ;(475 / 12375)$ conjoined valves, $\mathrm{L}=22.9, \mathrm{~W}=24.5$, $\mathrm{T}=10.2, \mathrm{Sw}=12.8 ;(476 / 12375)$ conjoined valves, $\mathrm{L}=16.5, \mathrm{~W}=19.8$, $\mathrm{T}=6.5, \mathrm{Sw}=11.2 ;(479 / 12375)$ conjoined valves, $\mathrm{L}=10.5, \mathrm{~T}=6.7$, $\mathrm{Sw}=6.7$.

Discussion. The Kazakh shells are comparable to Parastrophina haemiplicata (Hall), and in particular with specimens described and illustrated by Cooper (1956: 606, pl. 106, figs 33-44; pl. 117, figs 19-27) from the lower Martinsburg Formation of Virginia, in outline and profile of both valves, as well as in the characters of the radial ornament, dorsal median fold and ventral sulcus, but they differ in having more conspicuous ribbing on the flanks of mature shells, which may possess up to 7 ribs; however, the number of ribs is

Table 23 Measurements of complete shells of Parastrophina iliana sp. nov., Sample 948, Tesik river.

\begin{tabular}{lcccccccccc}
\hline & $\mathrm{L}$ & $\mathrm{W}$ & $\mathrm{T}$ & $\mathrm{Ld}$ & $\mathrm{Sw}$ & $\mathrm{St}$ & $\mathrm{L} / \mathrm{W}$ & $\mathrm{T} / \mathrm{L}$ & $\mathrm{Ld} / \mathrm{W}$ & $\mathrm{Sw} / \mathrm{W}$ \\
\hline $\mathrm{N}$ & 11 & 10 & 10 & 11 & 10 & 10 & 10 & 10 & 10 \\
$\mathrm{X}$ & 8.2 & 9.1 & 5.8 & 8.1 & 6.1 & 3.6 & $89.2 \%$ & $74.0 \%$ & $87.7 \%$ & $65.6 \%$ \\
$\mathrm{~S}$ & 2.05 & 2.87 & 1.16 & 2.10 & 1.65 & 1.52 & 6.3 & 10.4 & 5.2 & 6.5 \\
MIN & 5.5 & 5.6 & 4.2 & 5.3 & 3.2 & 1.6 & $80 \%$ & $62 \%$ & $79 \%$ & $57 \%$ \\
MAX & 11.9 & 14.8 & 7.4 & 11.7 & 8.5 & 6.6 & $98 \%$ & $95 \%$ & $95 \%$ & $78 \%$ \\
\hline
\end{tabular}




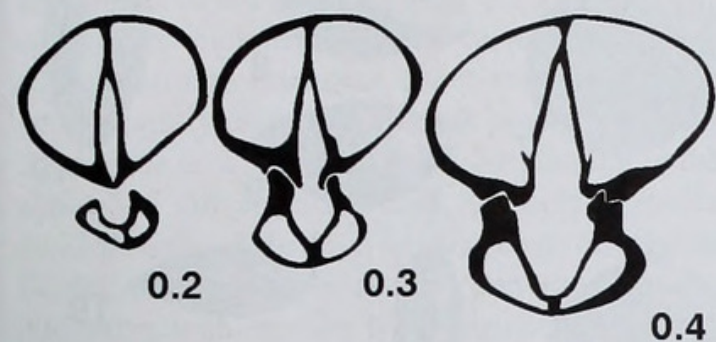

0

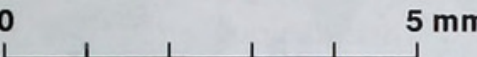

$5 \mathrm{~mm}$

0.4

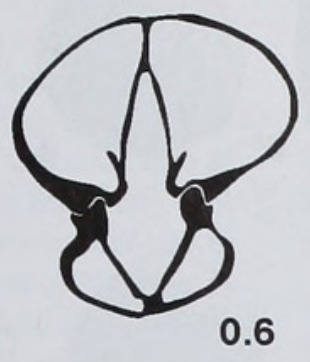

0.6

.

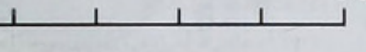

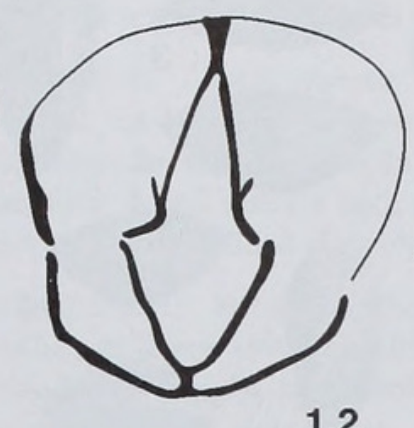

1.2

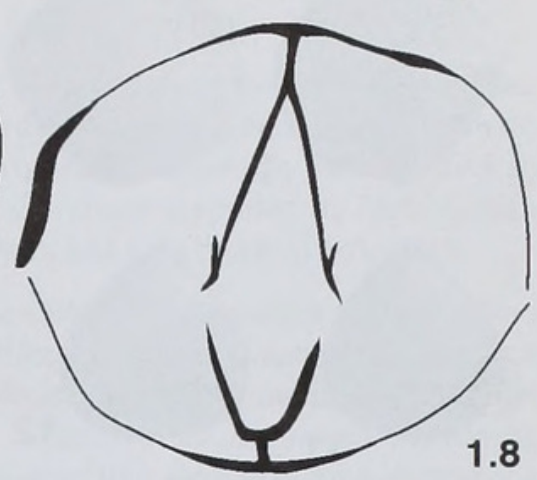

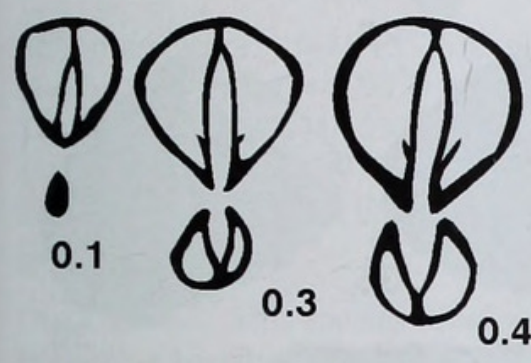
0.4
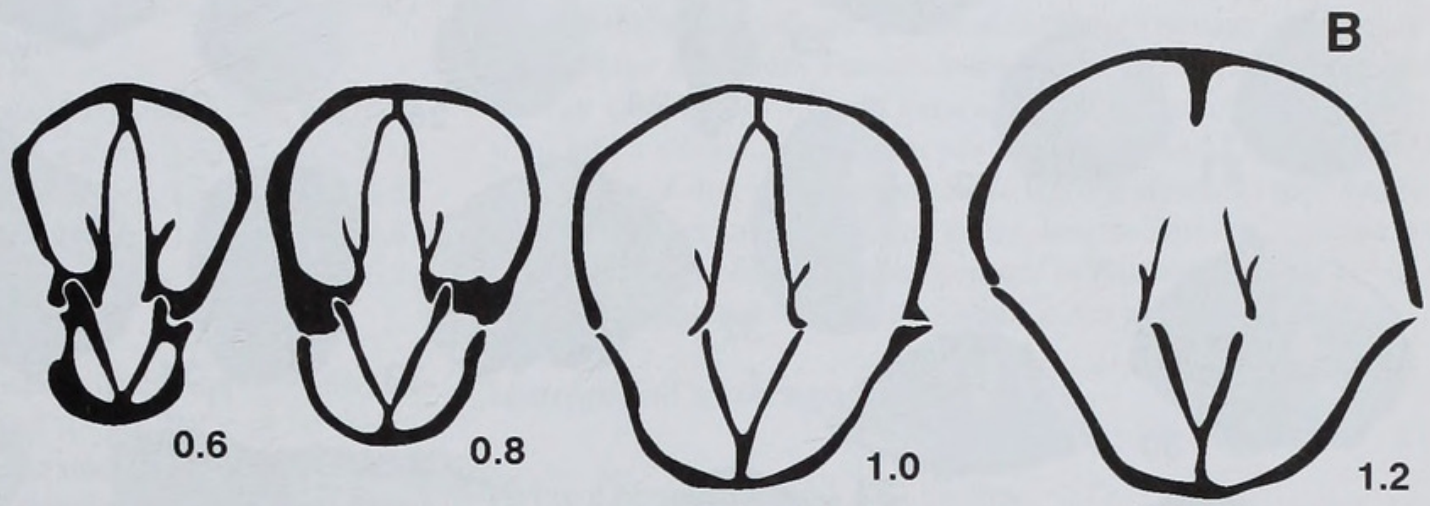

0

$5 \mathrm{~mm}$

Fig. 16 Transverse serial sections from Sample 948, Tesik River. A, Parastrophina iliana sp. nov., BC 57560; B, Parastrophina plena Sapelnikov \& Rukavishnikova, BC 57564. Distance in mm is measured from the posterior tip of ventral beak. Dorsal valve uppermost.

variable in the studied samples. There is also a strong tendency to asymmetry in the anterior commissure of the Kazakh shells. However, as mentioned by Cooper, his specimens were somewhat different from Hall's types and the species needs more substantial revision. Specimens from the Anderken Formation described by Rukavishnikova (1956) as Camerella haemiplicata (Hall) var. rotunda seem likely to represent a mixture of several taxa. In particular, the specimens illustrated on her pl. 2, fig. 2 may belong to Liostrophia, but others appear to be conspecific with ours. It is possible that the Kazakh shells are conspecific with the specimens described as Parastrophina haemiplicata by Fu (1982: 129, pl. 36, fig. 16) from the Jinhe Formation (Caradoc) of northwest China. The only illustrated specimen is similar to some of the juvenile Kazakh shells in ribbing and in the lateral profile of both valves, but it is impossible to estimate the limits of morphological variation in the Chinese population of Parastrophina from the published illustrations and description. There is remarkable general similarity between the brachiopod assemblage from the Jinhe Formation and the fauna from the carbonate mud-mounds in the upper Anderken Formation. In particular, both assemblages contain distinctive genera such as
Schizostrophina and Pectenospira (Popov et al. 1999) which are otherwise unknown elsewhere.

Parastrophina plena Sapelnikov \& Rukavishnikova, 1975 Pl. 13, figs 51-58; Figs 15, 16

1975 Parastrophina plena Sapelnikov \& Rukavishnikova: 27, pl. 1, figs 12-14.

1982 Parastrophina uniplicata Fu:130, pl. 36, fig. 17.

HoLOTYPE. IGNA 436/1861, conjoined valves, from the Anderken Formation, Sample 302 of Keller (1956), Anderkenyn-Akchoku section.

MATERIAL. 102 pairs of conjoined valves, 1 ventral and 2 dorsal valves from Samples 100 (=K-98/1970), 8223a (BC 56595), 8223b (BC 57248-52), 8226, Anderkenyn-Akchoku section; Samples 8214 (BC 57216-37, 57563), 8215 (BC 57238-47), west side of Ashchisu River; Samples 628 (BC 56598-600), 2536 (BC 56605-10), 2538 (BC 57562), 8217, 8219, 8256 (BC 56603-4), Kujandysai Section; Sample 948 (BC 57200-15), Tesik River.

Table 24 Measurements of ventral valves of Parastrophina plena Sapelnikov and Rukavishnikova, Sample 948, Tesik river.

\begin{tabular}{|c|c|c|c|c|c|c|c|c|c|c|}
\hline & $\mathrm{L}$ & W & $\mathrm{T}$ & Ld & Sw & $\mathrm{St}$ & $\mathrm{L} / \mathrm{W}$ & $\mathrm{T} / \mathrm{L}$ & $\mathrm{Ld} / \mathrm{W}$ & $\mathrm{Sw} / \mathrm{W}$ \\
\hline $\mathrm{N}$ & 34 & 34 & 34 & 34 & 31 & 33 & 34 & 34 & 34 & 31 \\
\hline$X$ & 6.6 & 7.1 & 4.8 & 6.7 & 4.3 & 3.1 & $93.6 \%$ & $72.7 \%$ & $94.3 \%$ & $60.7 \%$ \\
\hline $\mathrm{S}$ & 0.74 & 0.95 & 0.91 & 0.75 & 0.55 & 0.82 & 5.7 & 8.7 & 5.5 & 5.3 \\
\hline MIN & 5.5 & 5.8 & 3 & 5.5 & 3.4 & 1.4 & $83.0 \%$ & $52.6 \%$ & $83.6 \%$ & $52.9 \%$ \\
\hline MAX & 9 & 9.7 & 7.5 & 9 & 5.4 & 4.8 & $107.5 \%$ & $87.7 \%$ & $107.5 \%$ & $76.8 \%$ \\
\hline
\end{tabular}



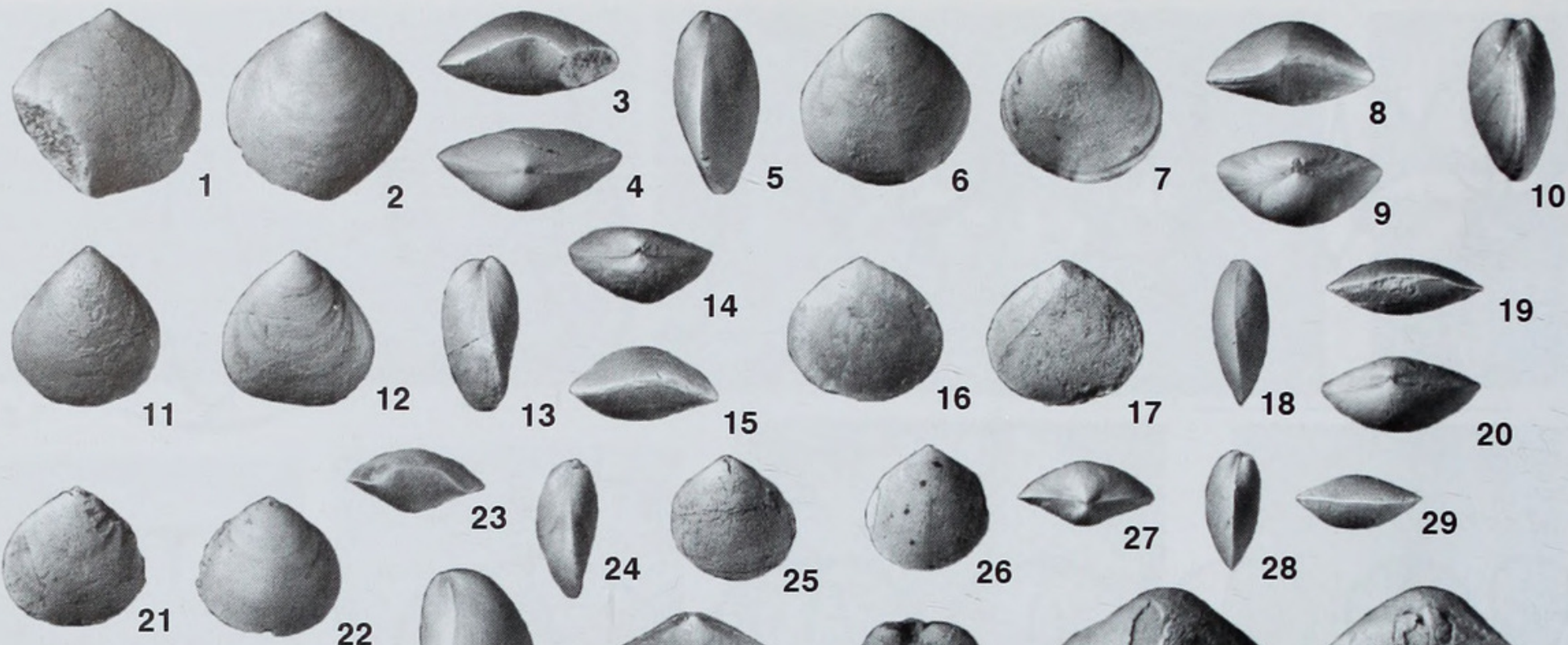

20
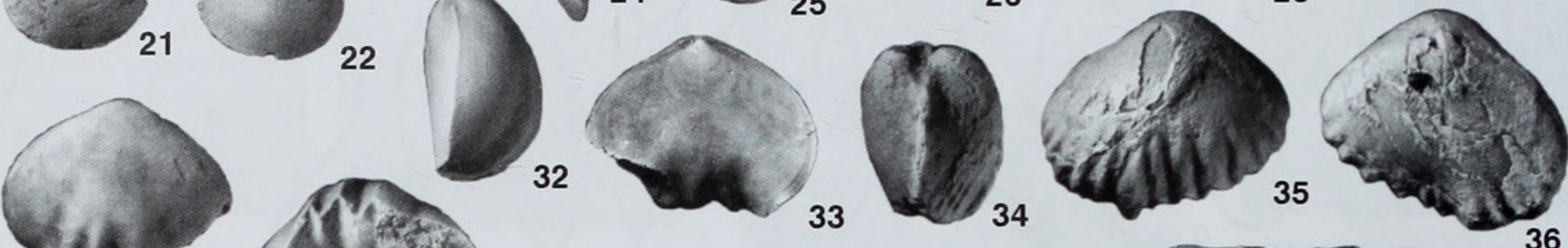

Q14 30
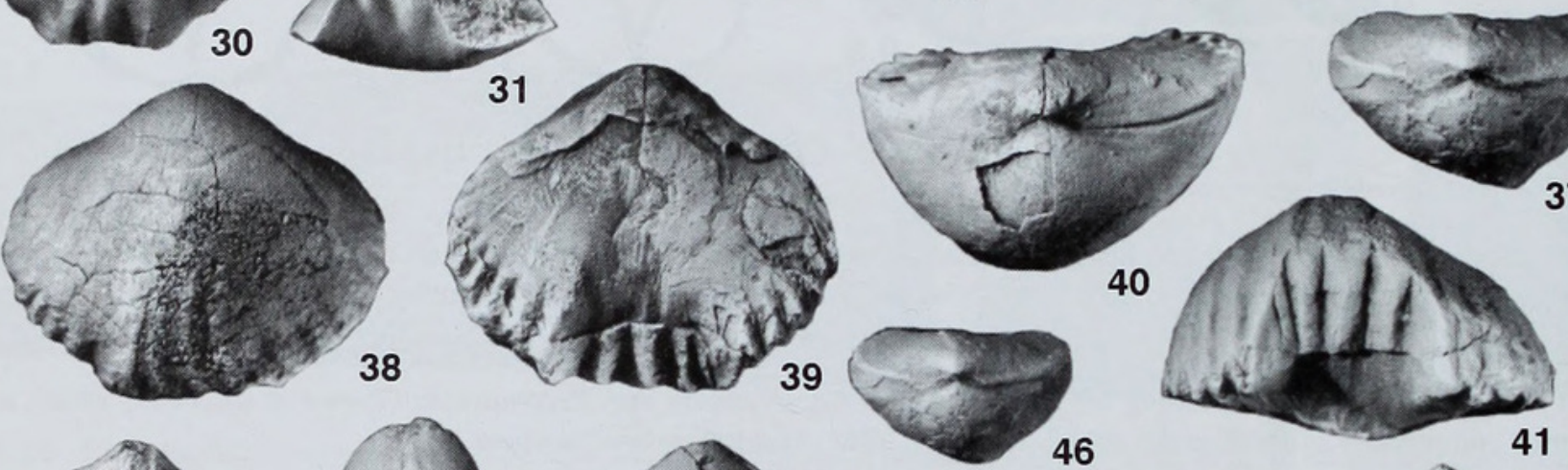

36
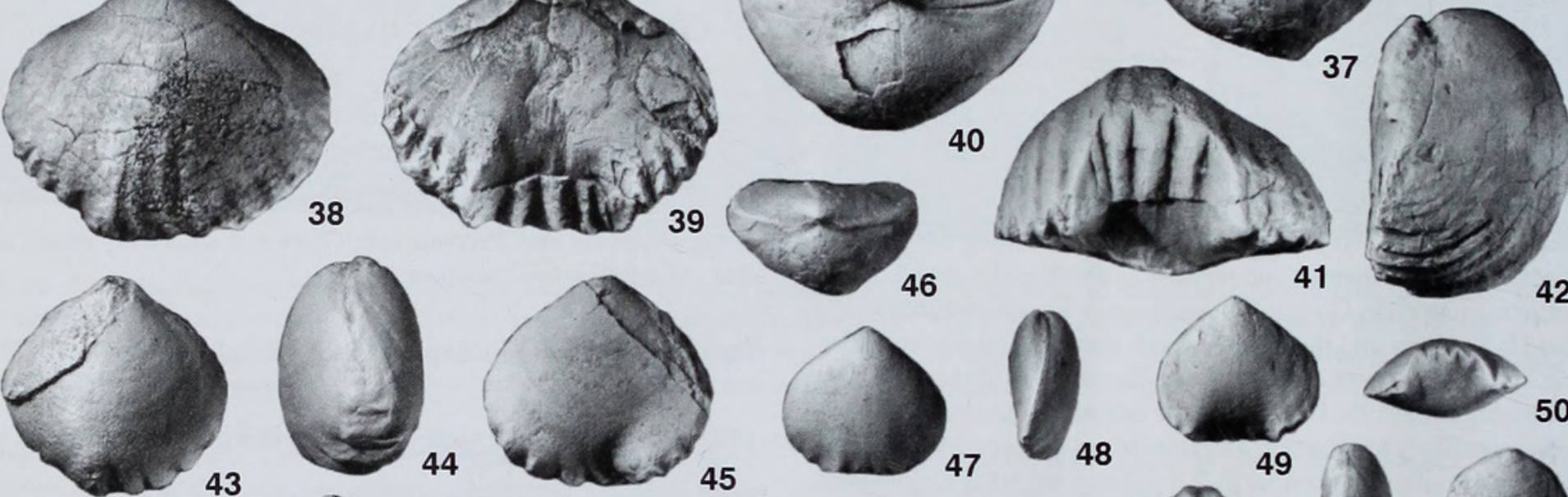

42
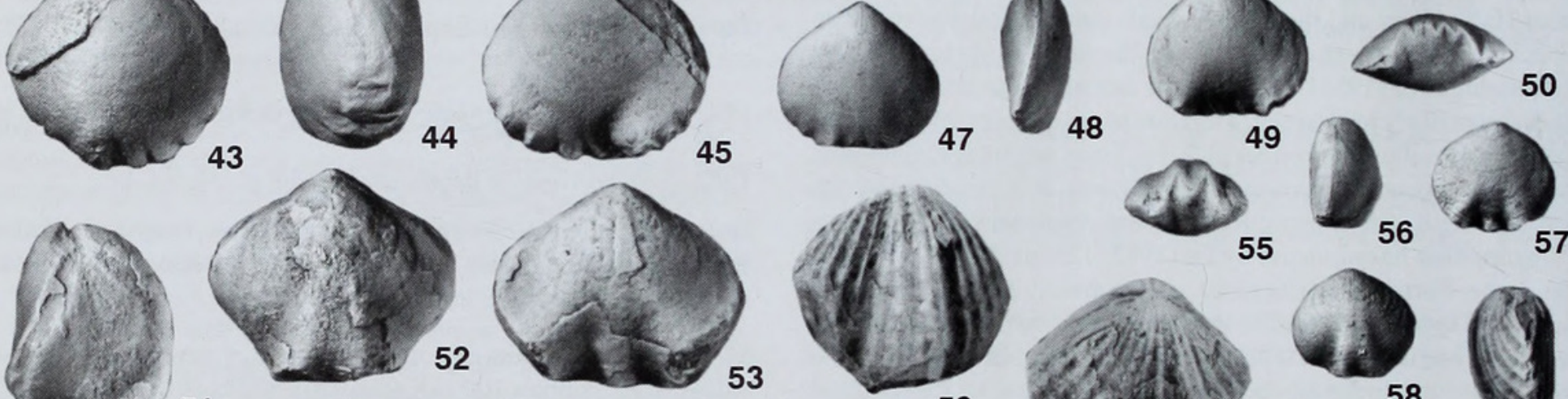

59

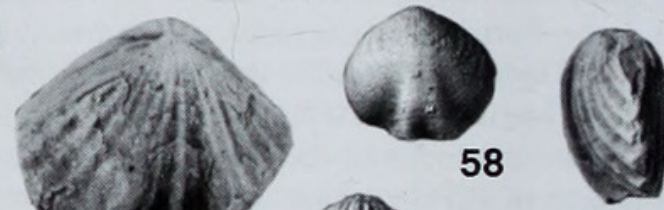

57
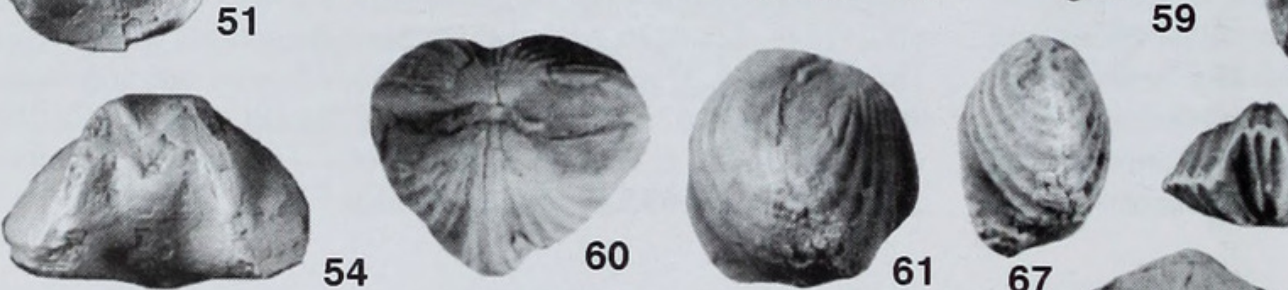

63
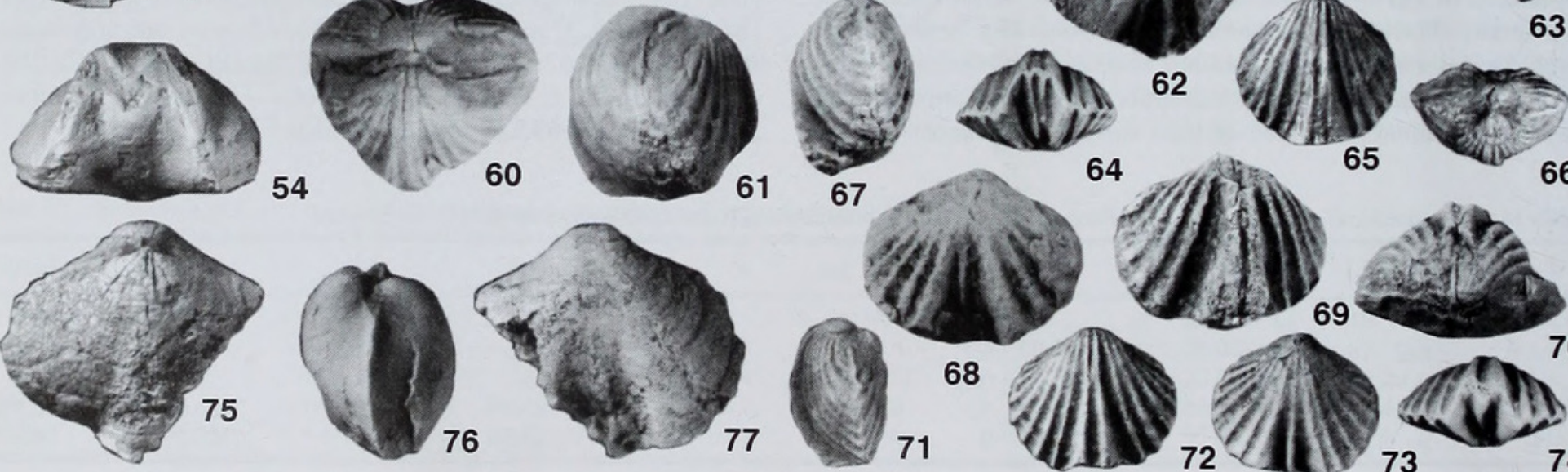
DESCRIPTION. Shell smooth, dorsibiconvex, subpentagonal in outline, about $70 \%$ as thick as long and $95 \%$ as long as wide. Anterior commisure sulciplicate. Ventral valve gently convex in lateral profile with maximum thickness about one-third valve length from the small, slightly erect pointed beak posterior to the hinge line. Sulcus about $60 \%$ as wide as the valve, originating in the umbonal area at about 4-5 mm from the beak, strongly deepening anteriorly and divided medianly by high angular costa originating near mid-valve. Dorsal valve strongly and evenly convex with maximum thickness at mid-valve with median fold originating slightly anterior to midvalve and bearing two strong angular ribs.

Ventral interior with small teeth and deep, narrow spondylium on the low median septum. Dorsal interior with narrow cruralium raised anteriorly on a low median septum extending anteriorly not more than $1.5 \mathrm{~mm}$ in adults. Inner plates small, thickened, slightly curved in cross-section. Brachial processes short.

MEASUREMENTS. (471/12375) conjoined valves, $\mathrm{L}=14.0, \mathrm{~W}=16.9$, $\mathrm{T}=6.3, \mathrm{Sw}=8.9 ;(474 / 12375)$ conjoined valves, $\mathrm{L}=20.4, \mathrm{~W}=21.0$, $\mathrm{T}=11.2, \mathrm{Sw}=8.7 ;(475 / 12375)$ conjoined valves, $\mathrm{L}=22.9, \mathrm{~W}=24.5$, $\mathrm{T}=10.2, \mathrm{Sw}=12.8 ;(476 / 12375)$ conjoined valves, $\mathrm{L}=16.5, \mathrm{~W}=19.8$, $\mathrm{T}=6.5, \mathrm{Sw}=11.2 ;(479 / 12375)$ conjoined valves, $\mathrm{L}=10.5, \mathrm{~T}=6.7$, $\mathrm{Sw}=6.7$.

DisCUSSION. This species usually occurs in the upper Anderken Formation together with Parastrophina iliana, but can be easily distinguished in being half the size, in the smooth shell with a single costa in the sulcus and two in the fold of mature specimens, and in the sulciplicate anterior commissure.

Parastrophina plena closely resembles Parastrophina uniplicata $\mathrm{Fu}, 1982$ from the Jinhe Formation (Caradoc) of northwest China in its smooth shell, sulciplicate anterior commissure, and in the characters of the dorsal fold and ventral sulcus. They may be conspecific.
Genus ILISTROPHINA Gen.nov.

TYPE SPECIES. Ilistrophina tesikensis sp.nov.

DIAGNOSIS. Shell smooth, ventribiconvex with well-developed dorsal median fold and ventral sulcus; ventral interior with spondylium sessile posteriorly, raised anteriorly on low median septum; dorsal interior with cruralium supported by high median septum; well defined alate plates and long brachial processes.

DISCUSSION. Externally Ilistrophina is most similar to Eostrophina (Zhan \& Rong 1995) but differs in having a narrow spondylium sessile posteriorly, raised anteriorly on a low median septum and well developed alate plates. It differs from Liostrophia in having strongly raised cruralium supported by a median septum instead of a sessile cruralium or separated outer plates; however, present knowledge of the interior of type species of the former remains inadequate. Ilistrophina resembles Parastrophina and Parastrophinella in the interior morphology of both valves, but differs in having a smooth shell and a sessile spondylium posteriorly. Jin and Copper (1997) demonstrated that in Parastrophinella the cruralium is supported by the median septum along its entire length, but, in contrast to Ilistrophina, the dorsal median septum in Parastrophinella is very low and buried within secondary shell in the apical area.

Ilistrophina tesikensis sp. nov.

Pl. 12. figs $28-35$; Figs 15,17

ETYMOLOGY. After the type locality.

HolOtyPe. BC 56823, Pl. 12, figs 32-35, conjoined valves, from Sample 948, Tesik River.

MATERIAL. 14 pairs of conjoined valves (including BC 56823-24) and one dorsal valve, all from Sample 948, Tesik River.

DESCRIPTION. Shell smooth, dorsibiconvex, subcircular in outline,

Table 25 Measurements of ventral valves of Ilistrophina tesikensis sp. nov., Sample 948, Tesik river.

\begin{tabular}{llllllllccc}
\hline & $\mathrm{L}$ & $\mathrm{W}$ & $\mathrm{T}$ & $\mathrm{Ld}$ & $\mathrm{Sw}$ & $\mathrm{St}$ & $\mathrm{L} / \mathrm{W}$ & $\mathrm{T} / \mathrm{L}$ & $\mathrm{Ld} / \mathrm{W}$ & $\mathrm{Sw} / \mathrm{W}$ \\
\hline $\mathrm{N}$ & 9 & 9 & 9 & 9 & 9 & 8 & 9 & 9 & 9 \\
$\mathrm{X}$ & 7.5 & 8.2 & 5.1 & 7.5 & 5.7 & 3.9 & $92.3 \%$ & $68.2 \%$ & $92.2 \%$ & $70.2 \%$ \\
$\mathrm{~S}$ & 1.01 & 1.46 & 0.82 & 0.98 & 0.96 & 0.94 & 4.7 & 6.6 & 4.9 & 5.4 \\
MIN & 6.2 & 6.4 & 4.2 & 6.2 & 4.6 & 2.4 & $83.8 \%$ & $58.3 \%$ & $82.9 \%$ & $63.9 \%$ \\
MAX & 9.8 & 11.7 & 6.8 & 9.7 & 7.8 & 5 & $97.5 \%$ & $79.4 \%$ & $97.5 \%$ & $80.7 \%$ \\
\hline
\end{tabular}

\section{PLATE 13}

Figs 1-29 Liostrophia pravula sp. nov., Akchoku Mountain, Kujandysai section. 1-15, Sample 8256; 1-5, BC 57550, conjoined valves, ventral, dorsal, anterior, posterior and lateral views, $\times 2$; 6-10, BC 57551, conjoined valves, dorsal, ventral, anterior, posterior and lateral views, $\times 2$; 11-15, BC 57552, conjoined valves, dorsal, ventral, lateral, posterior and anterior views, $\times 2.16-29$, Sample 2538; 16-20, BC 57553, holotype, conjoined valves, dorsal, ventral, lateral, anterior and posterior views, $\times 2$; 21-24, BC 57554, conjoined valves, ventral, dorsal, anterior and lateral views, $\times 2 ; 25-29$, BC 57555, conjoined valves, ventral, dorsal, posterior, lateral and anterior views, $\times 2$.

Figs 30-50 Parastrophina iliana sp.nov. 30-33, Sample 8217, Kujandysai section, BC 57556, conjoined valves, dorsal, anterior, lateral and ventral views, $\times 2.34-37$, Sample 2538, Kujandysai section, CNIGR 4/12361, conjoined valves, lateral, dorsal, ventral and posterior views, $\times 2$. 38-42, Sample 100, Anderkenyn-Akchoku section, BC 57557, holotype, conjoined valves, dorsal, ventral, posterior, anterior and lateral views, $\times 2.43-46$, Sample 8256, Kujandysai section, BC 57558, conjoined valves, dorsal, lateral, ventral and posterior views, $\times 2.47-50$, Sample 628, Kujandysai section, BC 57559, conjoined valves, dorsal, lateral, ventral and anterior views, $\times 2$.

Figs 51-58 Parastrophina plena Sapelnikov \& Rukavishnikova, 1975. 51-54, Sample 2538, Kujandysai section, BC 57562, conjoined valves, lateral, dorsal, ventral and anterior views, $\times 2$. 55-58, Sample 8214, Anderkenyn-Akchoku section, BC 57563, conjoined valves, anterior, lateral, ventral and dorsal views, $\times 2$.

Figs 59-74 Plectosyntrophia unicostata sp. nov., Anderkenyn-Akchoku section. 59-62, 67-70, Sample 626; 59-62, BC 57568, conjoined valves, dorsal, posterior, lateral, and ventral views, $\times 2 ; \mathbf{6 7 - 7 0}$, BC 57570, conjoined valves, holotype, lateral, ventral, dorsal and posterior views, $\times 2$. 63-66, 71-74, Sample 100; 63-66, BC 57569, conjoined valves, lateral, anterior, dorsal and posterior views, $\times 2$; 71-74, BC 57571, conjoined valves, lateral, dorsal ventral and anterior views, $\times 2$.

Figs 75-77 Didymelasma cf. transversa Fu, Sample 2538, Kujandysai section, BC 57573, conjoined valves, dorsal, lateral and ventral views, $\times 2$. 


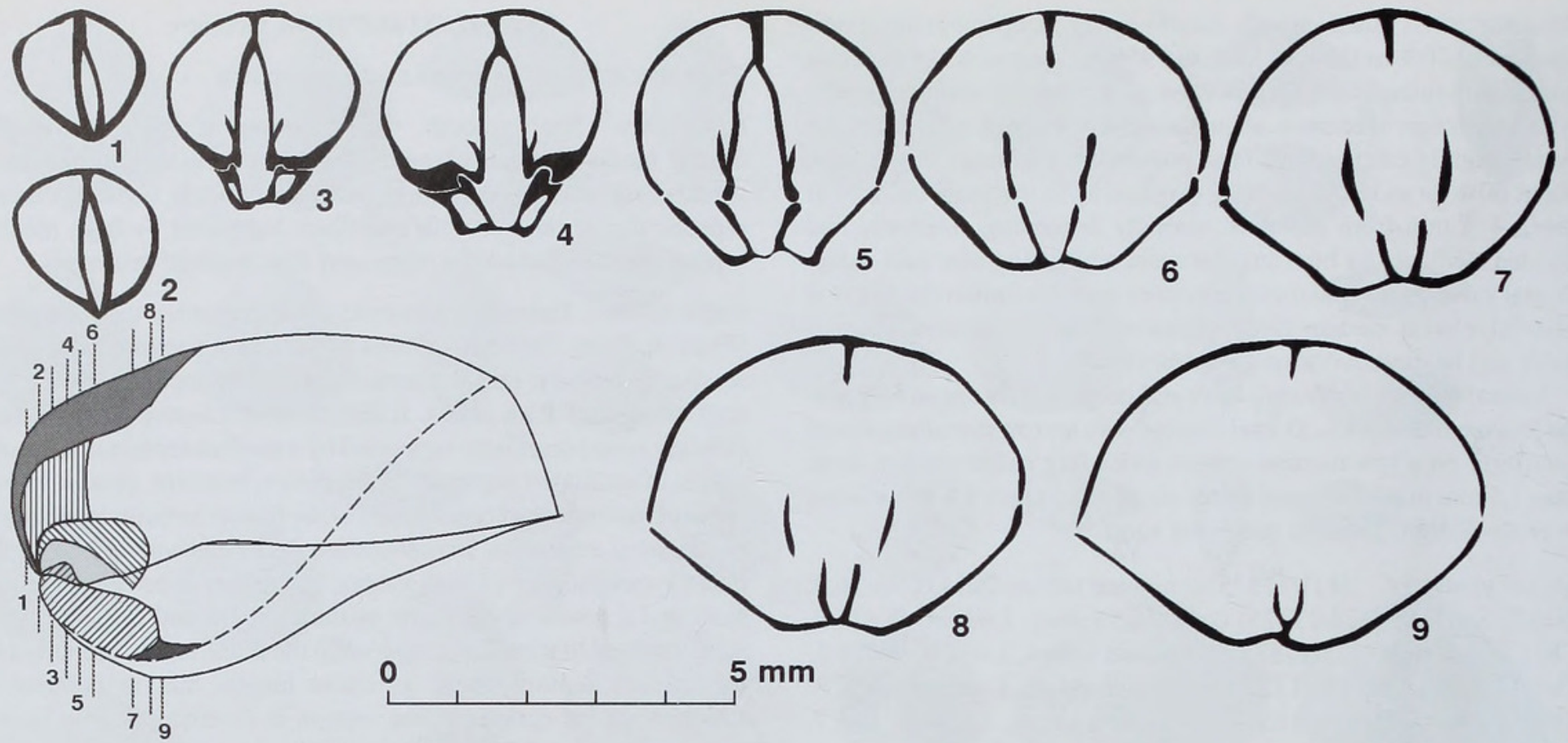

Fig. 17 Transverse serial sections of Ilistrophina tesikensis gen. et sp. nov., BC 57606, Sample 948, Tesik River. Distance in mm is measured from the posterior tip of ventral beak (dorsal valve uppermost), also an axial diagram showing the plates.

about $65 \%$ as high as long and $90 \%$ as long as wide with maximum width at mid-length. Anterior commissure strongly uniplicate. Ventral valve gently convex in lateral profile with maximum thickness somewhat posterior to mid-length. Beak small, curved towards the hinge line. Sulcus originating about $4-5 \mathrm{~mm}$ from the umbo, strongly deepening anteriorly and terminating with a high semioval tongue about $70 \%$ valve width. Dorsal valve with moderately convex lateral profile. Beak slightly swollen, curved. Dorsal median fold originating anterior to mid-length, semioval in cross-section.

Ventral interior with small teeth and narrow spondylium, bellshaped in cross-section, sessile posteriorly and raised anteriorly on a low, thick median septum extending to mid-valve length. Dorsal interior with cruralium supported by high median septum along its entire length. Inner plates present.

MEASUREMENTS. conjoined valves, $\mathrm{Lv}=9.8, \mathrm{~W}=11.7, \mathrm{~T}=6.8$, $\mathrm{Sw}=7.8, \mathrm{St}=4.0$; conjoined valves, $\mathrm{Lv}=7.8, \mathrm{~W}=8.2, \mathrm{~T}=5.7 ; \mathrm{Sw}=5.5$, $\mathrm{St}=4.7$.

Discussion. This species is externally comparable to Eostrophina uniplicata from the Middle Ashgill Xiazhen Formation of South China, but can be easily distinguished in its smaller size, which does not exceed $10 \mathrm{~mm}$ in length in the largest specimens, and in having a dorsal median fold evenly rounded in cross-section and originating anteriorly to the mid-valve.

Genus LIOSTROPHIA Cooper \& Kindle, 1936

TYPE SPECIES. Liostrophia glabra Cooper \& Kindle, 1936, from the Ashgill of Canada.

\section{Liostrophia pravula sp. nov.}

Pl. 13, figs 1-29; Fig. 18

ETYMOLOGY. After pravus, Latin - bowed.

HolotyPE. BC 57553, pl. 13, figs 16-20, conjoined valves, from the Anderken Formation, Sample 2538, Akchoku Mountain, Kuyandysai section.
MATERIAL. 30 pairs of conjoined valves, one ventral and 7 dorsal valves, from Samples 100 (=K-98/1970) (BC 57253-56), 626 (BC 57263-65), 8223, Anderkenyn-Akchoku section; Samples 2538 (BC 57266-69, 57553-55), 8256 (BC 57550-52), Kuyandysai section; Sample 948 (BC 57257-62), Tesik River.

DESCRIPTION. Shell slightly dorsibiconvex, transverse, subcircular in outline, about $51 \%$ as thick as long and $90 \%$ as long as wide, with maximum width at mid-length. Anterior commissure gently uniplicate. Ventral valve gently convex in lateral profile, with maximum thickness somewhat posterior to mid-length. Small, pointed beak, slightly erect and posterior to hinge line. Broad shallow sulcus, originating near the anterior margin, usually asymmetrical in crosssection. Dorsal valve moderately and evenly convex in profile with slightly swollen, curved beak. Dorsal median fold usually absent but weakly developed anteriorly in mature specimens. Shell surface smooth with one or two ribs in the fold and sulcus near the anterior margin of the largest specimens.

Ventral interior with teeth and spondylium supported anteriorly by very low septum enclosed posteriorly by a secondary shell thickening (Fig. 18). Dorsal interior with sessile cruralium formed by high outer plates joined at the valve floor. Alate plates small, appearing at some distance from the umbo. Inner plates small, slightly thickened, strongly curved in cross-section with the outer parts located almost within comissural plane. Brachial processes thin and relatively long.

MEASUREMENTS. (518/12375) conjoined valves, $\mathrm{L}=7.6, \mathrm{~W}=7.9$,

Table 26 Measurements of ventral valves of Liostrophia pravula sp. nov., Sample 2538, Kujandysai section.

\begin{tabular}{lcccccccc}
\hline & $\mathrm{L}$ & $\mathrm{W}$ & $\mathrm{T}$ & $\mathrm{Sw}$ & $\mathrm{St}$ & $\mathrm{L} / \mathrm{W}$ & $\mathrm{T} / \mathrm{L}$ & $\mathrm{Sw} / \mathrm{W}$ \\
\hline $\mathrm{N}$ & 11 & 11 & 11 & 10 & 10 & 9 & 9 & 9 \\
$\mathrm{X}$ & 5.7 & 6.3 & 2.9 & 4.1 & 1.5 & $89.7 \%$ & $50.9 \%$ & $61.8 \%$ \\
$\mathrm{~S}$ & 1.45 & 1.56 & 1.05 & 0.75 & 0.18 & 7.6 & 6.3 & 3.7 \\
MIN & 3.3 & 3.5 & 1.3 & 3.2 & 1.2 & $81.5 \%$ & $42.6 \%$ & $57.1 \%$ \\
MAX & 8.2 & 9.2 & 5.1 & 5.7 & 1.8 & $103.8 \%$ & $62.2 \%$ & $70.2 \%$ \\
\hline
\end{tabular}



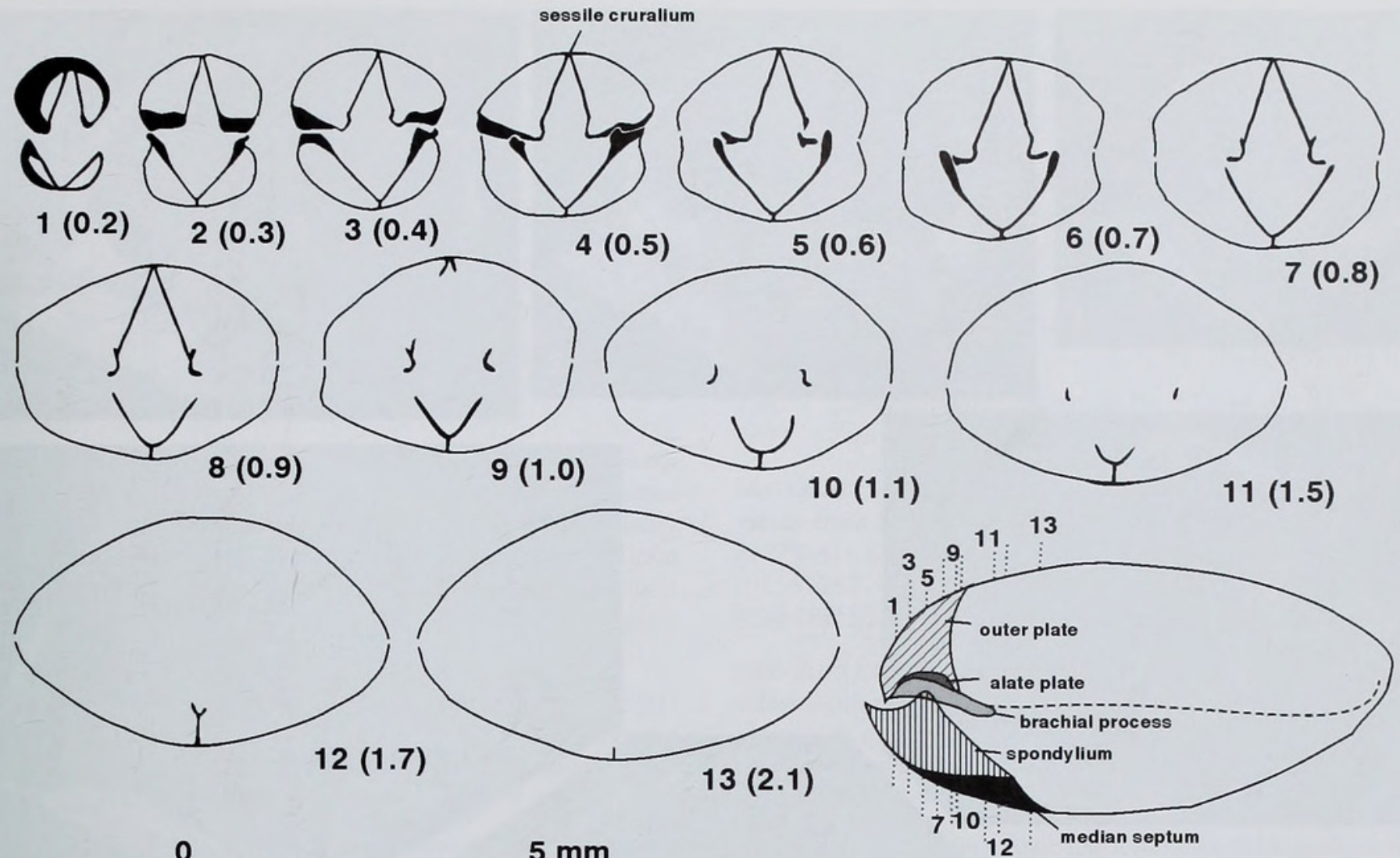

0

$5 \mathrm{~mm}$

12

Fig. 18 Transverse serial sections of Liostrophia pravula sp.nov., Sample 2538, Kujandysai section. Distance in mm is measured from the posterior tip of ventral beak. Dorsal valve uppermost. Also lateral view to show section positions and schematic reconstruction.

$\mathrm{T}=3.4 ;(519 / 12375)$ conjoined valves, $\mathrm{L}=5.2, \mathrm{~W}=5.7, \mathrm{~T}=2.0 ;(520 /$ $12375)$ conjoined valves, $\mathrm{L}=7.9, \mathrm{~W}=7.9, \mathrm{~T}=3.2 ;(521 / 12375)$ conjoined valves, $\mathrm{L}=8.7, \mathrm{~W}=8.2, \mathrm{~T}=4.1 ;(522 / 12375)$ conjoined valves, $\mathrm{L}=5.8, \mathrm{~T}=6.3, \mathrm{Sw}=3.7 .1 ;(523 / 12375)$ conjoined valves, $\mathrm{L}=10.6$, $\mathrm{T}=10.5, \mathrm{Sw}=4.7$.

DisCUSSION. This species differs from Liostrophia glabra Cooper \& Kindle in having a subcircular outline, weak ventral sulcus and in the absence of a dorsal median fold. The characters of the dorsal interior in the type species remain inadequately known. In particular it is unclear from the existing illustrations whether or not it has a sessile cruralium or if it is supported anteriorly by a very short septum. In external morphology, particularly in the smooth, rounded shell with an uniplicate anterior commissure but without a distinct dorsal median fold, Liostrophia pravula resembles Psilocamera planisulcata Fu, 1982 from the the Jinhe Formation (Caradoc) of north-west China. However, in the single transverse section provided by Fu (1982, text-fig. 18A) the outer plates appear to be completely separate and there are no alate plates or inner plates illustrated.

Liostrophia pravula differs from juvenile specimens of Ilistrophina

Table 27 Measurements of ventral valves of Plectosyntrophia unicostata sp. nov., samples 100 and 626 from Anderkenyn-Akchoku section.

\begin{tabular}{lcclllccc}
\hline & $\mathrm{L}$ & $\mathrm{W}$ & $\mathrm{T}$ & $\mathrm{St}$ & $\mathrm{Sw}$ & $\mathrm{L} / \mathrm{W}$ & $\mathrm{T} / \mathrm{L}$ & $\mathrm{Sw} / \mathrm{W}$ \\
\hline $\mathrm{N}$ & 6 & 6 & 6 & 6 & 6 & 6 & 6 & 6 \\
$\mathrm{X}$ & 9.5 & 10.7 & 7.2 & 4.0 & 5.8 & $89.4 \%$ & $74.1 \%$ & $156.2 \%$ \\
$\mathrm{~S}$ & 1.37 & 2.10 & 2.77 & 1.87 & 1.82 & 4.6 & 18.3 & 28.4 \\
MIN & 7.8 & 8.4 & 4.6 & 2.2 & 3.5 & $82.9 \%$ & $59.0 \%$ & $119.6 \%$ \\
MAX & 11 & 13.2 & 11.2 & 6.5 & 7.9 & $92.9 \%$ & $101.8 \%$ & $177.1 \%$ \\
\hline
\end{tabular}

tesikensis not only in its larger size and sessile cruralium (which hardly exceeds half the maximum length), but also in the absence of a dorsal median fold. A ventral sulcus is present in Ilistrophina tesikensis when specimens are 4-5 $\mathrm{mm}$ long, whereas in Liostrophia pravula it is visible only in mature specimens which exceed the average shell size of about $6 \mathrm{~mm}$.

\section{Subfamily ANASTROPHIINAE Nikiforova, 1960 Genus PLECTOSYNTROPHIA Fu, 1982}

TYPE SPECIES. Plectosyntrophia qilianshanensis $\mathrm{Fu}, 1982$, from the Yingou Group (Middle Ordovician) of North China.

\section{Plectosyntrophia unicostata sp. nov.}

Pl. 13, figs 59-74; Fig. 19

HolotyPE. BC 57570, Pl. 13, figs 67-70, conjoined valves from Sample 626, Anderkenyn-Akchoku section.

MATERIAL. Seven pairs of conjoined valves and one dorsal valve from Samples 100 (=K-98/1970) (BC 57569, 71), 620 (BC57360), 626 (BC 57271-73, 57568, 70, 72), 8214 (BC 57361), AnderkenynAkchoku section; Samples 2538, 8217 (BC 57362), Kujandysai Section.

DESCRIPTION. Shell subequally biconvex, transverse, subpentagonal in outline, about $75 \%$ as thick as long and about $89 \%$ as long as wide with maximum width slightly anterior to mid-length. Anterior commissure uniplicate. Ventral valve moderately convex with curved beak slightly raised above a narrow triangular, apsacline interarea. Ventral sulcus narrow and shallow, but with steep lateral 


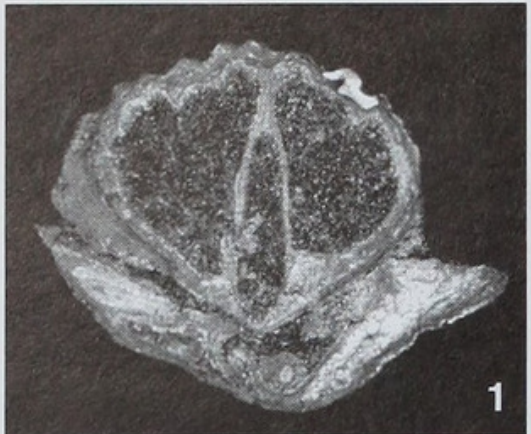

1

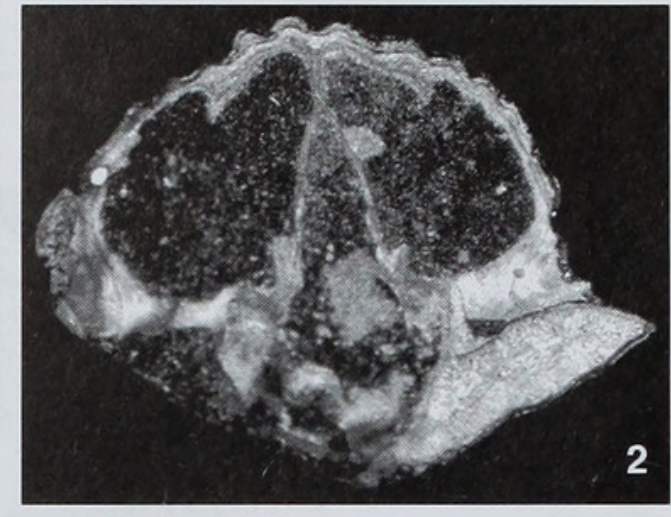

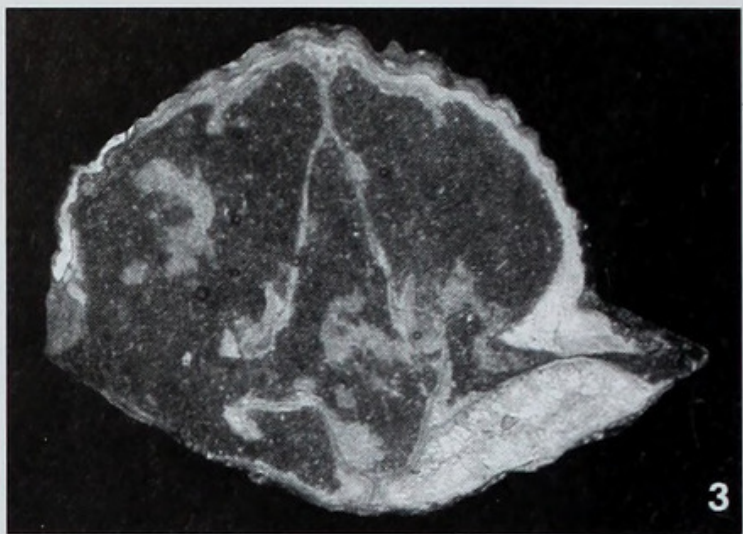

3

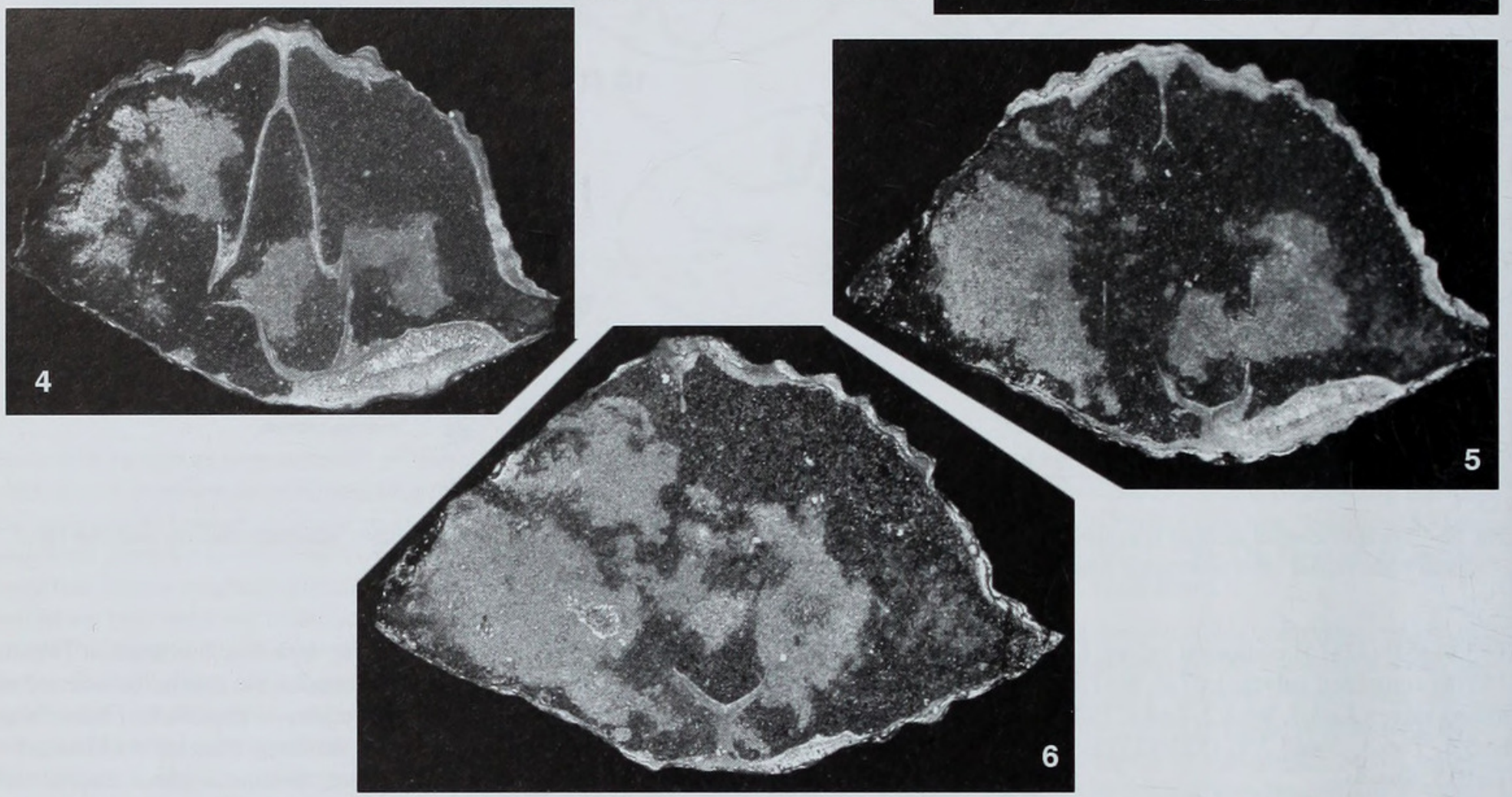

Fig. 19 Photographs of transverse serial sections of Plectosyntrophia unicostata sp. nov., BC 57572, from Sample 626, Anderkenyn-Akchoku section; ×

12. Distance in $\mathrm{mm}$ is measured from the posterior tip of ventral beak. Dorsal valve uppermost.

slopes, originating slightly posteriorly to mid-valve, and ending with a shallow, narrow, trapezoidal tongue about $40 \%$ valve width. Dorsal valve strongly convex in lateral profile with maximum thickness near mid-length. Beak slightly swollen and strongly curved towards the hinge line. A low, flattened median fold originates from the umbo. Radial ornament mainly costate, with occasional bifurcating ribs and with 1 primary rib in the sulcus, 2 primary ribs in the median fold and 6-9 on the lateral slopes of the valves. In some specimens one or two small secondary costellae originate in the median fold and dorsal sulcus between the umbo and mid-length. Ventral interior with strong teeth; bell-shaped spondylium in transverse section, sessile posteriorly and raised anteriorly on a low median septum partly covered by secondary shell (Fig. 19). Dorsal interior with narrow cruralium on a high median septum extending anteriorly up to $3 \mathrm{~mm}$ in adults. Inner plates narrow, curved; alate plates narrow, bordered laterally by a pair of high subparallel muscle bounding ridges.

MEASUREMENTS. (CNIGR 471/12375) conjoined valves, $\mathrm{L}=14.0$, $\mathrm{W}=16.9, \mathrm{~T}=6.3, \mathrm{Sw}=8.9 ;(474 / 12375)$ conjoined valves, $\mathrm{L}=20.4$, $\mathrm{W}=21.0, \mathrm{~T}=11.2, \mathrm{Sw}=8.7 ;(475 / 12375)$ conjoined valves, $\mathrm{L}=22.9$, $\mathrm{W}=24.5, \mathrm{~T}=10.2, \mathrm{Sw}=12.8 ;(476 / 12375)$ conjoined valves, $\mathrm{L}=16.5$,
$\mathrm{W}=19.8, \mathrm{~T}=6.5, \mathrm{Sw}=11.2 ;(479 / 12375)$ conjoined valves, $\mathrm{L}=10.5$, $\mathrm{T}=6.7, \mathrm{Sw}=6.7$.

DISCUSSION. The generic attribution of unicostata is tentative because the interior of Plectostrophia qilianshanensis is inadequately known. In particular, there is no record of the presence of alate plates in the type species, but some illustrations provided in the original description (Fu 1982, text-fig. 17) suggest their presence. The characters of the ventral interior, in particular the presence of a sessile spondylium slightly raised near its anterior margin on a short septum, also needs confirmation, because Fu's illustrations are schematic and it could be a preservational pattern. In the Kazakh species alate plates are well defined, whereas the sessile spondylium is present only in the earliest ontogenetic stages and is characterised by a spondylium supported by a low median septum partly covered by secondary shell. Plectosyntrophia qilianshanensis has 3 ribs in the ventral sulcus and 4 in the dorsal fold, which makes it more similar to Eoanastrophia kurdaica than to our species.

P. unicostata differs from Eoanastrophia kurdaica Sapelnikov \& Rukavishnikova (1975) from the Keskentas Formation (Caradoc), of the Kendyktas Range, south Kazakhstan, in having a more pronounced dorsal median fold with two primary ribs and a ventral 
sulcus with a single accentuated primary rib originating in the umbonal area. The coarsely ribbed radial ornament, well defined dorsal median fold and ventral sulcus resembles numerous species of Plectocamara described by Cooper (1956) from the Caradoc of North America, but there is no evidence of the presence of alate plates in the former genus.

\section{Family PARALELLELASMATIDAE Cooper, 1956 Genus SCHIZOSTROPHINA Fu, 1982}

TYPE SPECIES. Schizostrophina margarita Fu, 1982, from the Jinhe Formation (Caradoc), northwest China.

DiAGNOSIS (emended). Shell equally biconvex with parasulcate anterior commissure; shallow ventral median sulcus and dorsal median fold originating in umbonal area; radial ornament of variably developed coarse angular ribs in posterior half of the shell; ventral interior with delicate teeth and spondylium supported posteriorly and free anteriorly; dorsal interior with separated outer plates, slightly diverging distally, and well-defined brachial processes.

DISCUSSION. Schizostrophina was erected originally by Fu (1982) without proper illustrations and detailed description of the interior in the type species. However, the very distinctive exterior morphology of the shell, which is unique in late Ordovician syntrophiidines, leaves no doubt that the Kazakh shells from the Anderken Formation belong to the same genus and species. Their internal morphology confirms the original assignment of the genus to the Paralellelasmatidae and suggests a close affinity to Paralellelasma, but Schizostrophina lacks the radial capillae and the characteristic truncated margins of the ribs along the commissure of the former genus. Another difference is the parasulcate anterior commissure.

\section{Schizostrophina margarita $\mathrm{Fu}, 1982$}

Pl. 14, figs 2-27; Fig. 20

1982 Schizostrophina margarita Fu: 132, pl. 37, fig. 5.

1982 Schizostrophina shaanxiensis Fu: 133, pl. 37, fig. 6.

MATERIAL. 26 pairs of conjoined valves, 6 ventral and 4 dorsal valves from Samples 100 (=K-98/1970) (BC 57275-7), 626 (BC 57279-81), 8223, Anderkenyn-Akchoku section; Samples 628, 2538 (BC 57282-92, 57574-78), 8219 (BC 57294), 8220 (BC 57295), 8256 (BC 57296-9), Kujandysai Section.

DESCRIPTION. Shell equally biconvex, subpentagonal to subtriangular in outline; about as long as wide, with maximum width anterior to mid-valve. Anterior commissure parasulcate. Beaks of both valves swollen and strongly curved. Ventral valve moderately

Table 28 Measurements of ventral valves of Schizostrophina margarita Fu, Samples 626, 2538, 8256 from Anderkenyn-Akchoku and Kujandysai sections.

\begin{tabular}{lcccccccccc}
\hline & $\mathrm{L}$ & $\mathrm{W}$ & $\mathrm{T}$ & $\mathrm{Sw}$ & $\mathrm{St}$ & $\mathrm{L} / \mathrm{W}$ & $\mathrm{T} / \mathrm{L}$ & $\mathrm{Sw} / \mathrm{W}$ & $\mathrm{Ld} / \mathrm{W}$ & $\mathrm{Sw} / \mathrm{W}$ \\
\hline $\mathrm{N}$ & 18 & 18 & 18 & 17 & 3 & 18 & 18 & 17 & 9 \\
$\mathrm{X}$ & 5.8 & 6.2 & 4.2 & 4.3 & 4.3 & $94.8 \%$ & $71.4 \%$ & $71.7 \%$ & $92.2 \%$ & $70.2 \%$ \\
$\mathrm{~S}$ & 1.24 & 1.68 & 1.25 & 1.55 & 0.92 & 6.0 & $9.3 \%$ & 14.5 & 4.9 & 5.4 \\
MIN & 3.6 & 3.7 & 2.1 & 2.6 & 3.2 & $79.6 \%$ & $54.5 \%$ & $45.2 \%$ & $82.9 \%$ & $63.9 \%$ \\
MAX & 8.0 & 9.8 & 6.2 & 7.8 & 4.8 & $102.2 \%$ & $90.4 \%$ & $100.0 \%$ & $97.5 \%$ & $80.7 \%$ \\
\hline
\end{tabular}

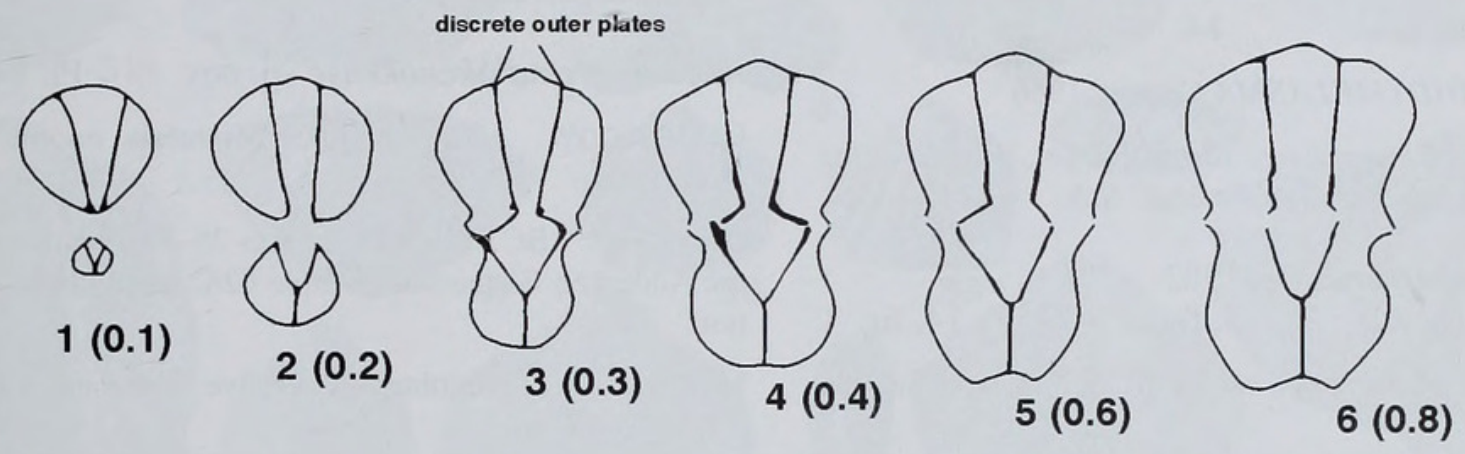

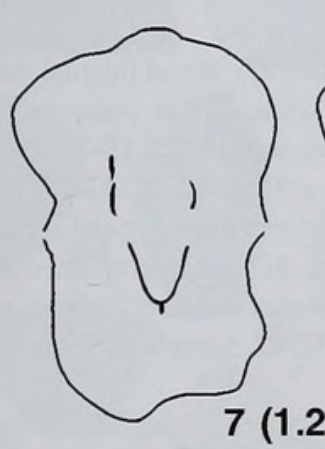

0

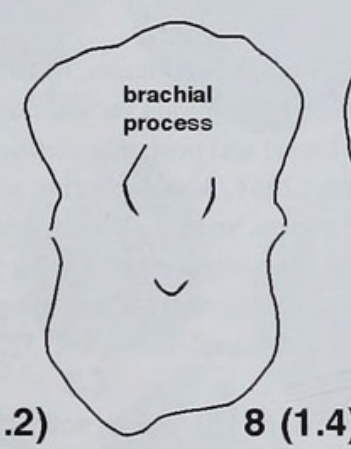

$5 \mathrm{~mm}$

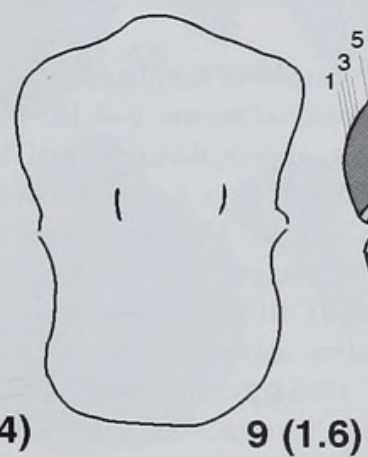

9 (1.6)
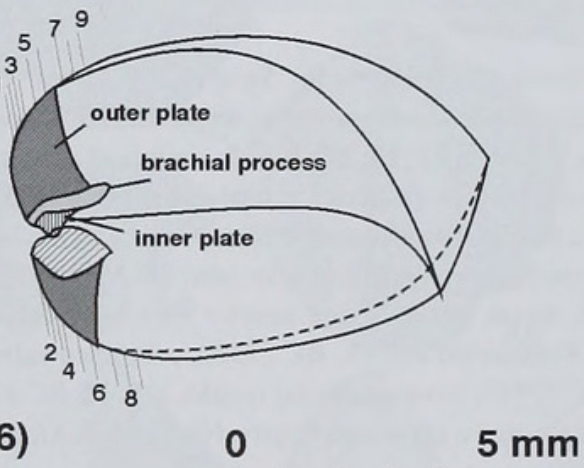

Fig. 20 Transverse serial sections of Schizostrophina margarita Fu, Sample 2538, Kujandysai section. Distance in mm is measured from the posterior tip of ventral beak. Dorsal valve uppermost. Also lateral view to show section positions and schematic reconstruction. 
convex in lateral profile with maximum thickness slightly posterior to mid-valve. Ventral sulcus originating near the umbo, broad and shallow with low trapezoidal tongue slightly inclined anteriorly. Lateral slopes steep, slightly convex in cross-section. Dorsal valve with moderately convex lateral profile strongly curved posteriorly. Median fold shallow, slightly rounded in transverse section, originating near the beak, flanked by two strong plications. Radial ornament with angular ribs originating near mid-length, 1-3 ribs in the sulcus and 2-4 in the median fold. Pair of ribs occasionally on the lateral slopes of both valves. Ventral interior with deep, narrow spondylium about one-sixth valve length, supported posteriorly by high median septum, free anteriorly. Dorsal interior with separated outer plates, slightly diverging distally, short subtriangular brachial plates and well-defined brachial processes.

MEASUREMENTS. conjoined valves, $\mathrm{L}=7.9, \mathrm{~W}=8.6, \mathrm{~T}=5.9, \mathrm{Sw}=6.9$; conjoined valves, $\mathrm{L}=9.8, \mathrm{~W}=11.2, \mathrm{~T}=6.7, \mathrm{Sw}=8.2$; conjoined valves, $\mathrm{L}=7.8, \mathrm{~W}=8.2, \mathrm{~T}=6.2, \mathrm{Sw}=6.8$; conjoined valves, $\mathrm{L}=6.8, \mathrm{~W}=7.2$, $\mathrm{T}=6.2, \mathrm{Sw}=5.4$; conjoined valves, $\mathrm{L}=5.7, \mathrm{~W}=5.8, \mathrm{~T}=3.4, \mathrm{Sw}=4.6$.

DISCUSSION. Schizostrophina margarita, the type species of the genus, came from the same unit and locality, the Jinhe Formation (Lower Caradoc) of north-west China, as S. shaanxiensis and differs from the latter in having a single poorly defined rib in the ventral sulcus and smooth lateral sides of the valve. The Kazakh shells demonstrate a strong variability in the number and characters of radial ornament with growth. The small shells (about 5-6 mm long) usually lack ribs on the lateral sides of the shell, and the radial ornament in the ventral sulcus and dorsal fold is poorly developed or absent (Pl.14, figs 22-24), whereas mature specimens possess a radial ornament closely comparable to one of the specimens referred by $\mathrm{Fu}(1982)$ to $S$. shaanxiensis. This suggests that all the shells described by Fu represent a single species, which should be termed $S$. margarita. Since there appear to be no constant morphological differences between the Kazakh and Chinese specimens of Schizostrophina, they are regarded here as conspecific.

\section{Genus DIDYMELASMA Cooper, 1956}

TYPE SPECIES. Didymelasma longicrurum Cooper, 1956 from the Lebanon Formation (Caradoc), Tennessee, U.S.A

\section{Didymelasma cf. transversa $\mathrm{Fu}, 1982$}

$$
\text { Pl. 13, figs 75-77, Pl. 14, fig. } 1
$$

MATERIAL. One pair of conjoined valves, BC 57573, from Sample
2538, Kujandysai Section; one dorsal internal mould (BC 57366) from Sample 1018, 7 km southwest of Karpkuduk well, Kotnak Mountains.

DESCRIPTION. Shell smooth, subequally biconvex, transverse to suboval in outline with uniplicate posterior commissure. Ventral valve lateral profile moderately convex with maximum thickness about one-third valve length. Ventral beak swollen and slightly curved. Sulcus originating near mid-length, strongly deepening towards the anterior margin, with low median rib. Tongue semielliptical. Dorsal valve moderately convex in lateral profile with maximum thickness at about two-thirds valve length. Median fold originating somewhat posteriorly to mid-valve, clearly separated from the slightly convex lateral sides of the valve. Ventral interior unknown, except for median septum, possibly supporting spondylium. Dorsal interior with separated, long, subparallel outer plates.

MEASUREMENTS. conjoined valves, $\mathrm{L}=13.4, \mathrm{~T}=8.2$.

Discussion. The Kazakh specimens closely resemble Didymelasma transversa Fu, 1982, from the Caradoc Jinhe Formation of northwest China, in the external features of their smooth shells, including the shape of the dorsal median fold and ventral sulcus, but our material is insufficient to make a precise attribution to this species. Fu (1982, text-fig. 23) also demonstrated the presence of separated, subparallel outer plates in the Chinese shells, which supports their assignation to Didymelasma.

\section{Order RHYNCHONELLIDA Kuhn, 1949 Superfamily RHYNCHOTREMATOIDEA Schuchert, 1913 Family RHYNCHOTREMATIDAE Schuchert, 1913 Genus RHYNCHOTREMA Hall, 1860}

TYPE SPECIES. Atrypa increbescens Hall, 1847, from the Trenton Formation (Caradoc), New York, U.S.A.

\section{Rhynchotrema akchokense sp. nov. $\quad$ Pl. 14, figs 28-42}

ETYMOLOGY. After Akchoku Mountain on the east side of Kopalysai.

HoLOTYPE. BC 57579, Pl. 14, figs 28-32, conjoined valves, from the Anderken Formation, Sample 626, Anderkenyn-Akchoku section.

MATERIAL. 11 conjoined valves, five ventral and six dorsal valves

\section{PLATE 14}

Fig. 1 Didymelasma cf. transversa Fu, Sample 1018, area 7 km SW of Karpkuduk well, Kotnak Mountains, BC 57366, dorsal internal mould, $\times 2$.

Figs 2-27 Schizostrophina margarita Fu, Sample 2538, Kujandysai section. 2-6, BC 57574, conjoined valves, dorsal, ventral, posterior, lateral and anterior views, $\times 3 . \mathbf{7 - 9}, \mathbf{1 1}, \mathbf{1 4}$, BC 57575, conjoined valves, anterior, dorsal, ventral, lateral and posterior views, $\times 3 . \mathbf{1 0}, \mathbf{1 2}, \mathbf{1 5 - 1 7}$, BC 57576, conjoined valves, anterior, posterior, dorsal, lateral and ventral views, $\times 3.13$, CNIGR 5/12361, dorsal exterior, $\times 3.18-22$, BC 57577, conjoined valves, lateral , dorsal, ventral, anterior and posterior views, $\times 3$. 23-27, BC 57578, conjoined valves, ventral, dorsal, lateral, posterior and anterior views, $\times 3$.

Figs 28-42 Rhynchotrema akchokense sp. nov. 28-32, 38-41, Sample 626, Anderkenyn-Akchoku section; 28-32, BC 57579, conjoined valves, holotype, ventral, lateral, dorsal, posterior and anterior views, $\times 2$; 38-41, BC 57582, conjoined valves, dorsal, ventral, anterior and lateral views, $\times 3.33-\mathbf{3 6}$, Sample 2538, Kujandysai section, BC 57580, conjoined valves, anterior, dorsal, ventral and lateral views, $\times 2.37$, 42, Sample 843 , Anderkenyn-Akchoku section; 37, BC 57581, ventral internal mould, $\times 3 ; \mathbf{4 2}$, BC 57583, dorsal internal mould, $\times 5$.

Figs 43-46 Pectenospira pectenata Popov, Nikitin \& Sokiran, Sample 948, Tesik River, BC 57320, dorsal, anterior, ventral and lateral views of conjoined valves, $\times 5.5$.

Figs 47-57 Nikolaispira guttula sp.nov. 47-53, Sample 2538, Kujandysai section; 47-49, BC 57584, conjoined valves, anterior, dorsal and ventral views, $\times 3 ; \mathbf{5 0 - 5 3}$, BC 57585, conjoined valves, holotype, ventral, anterior, lateral and dorsal views, $\times 3.54-57$, Sample 8221 , Anderkenyn-Akchoku section, BC56770, conjoined valves, anterior, ventral, dorsal and lateral views, $\times 4$.

Figs 58-61 Kellerella misiusi Popov, Nikitin \& Sokiran, Sample 8214, Anderkenyn-Akchoku section. BC 56773, conjoined valves, anterior, ventral, lateral and dorsal views, $\times 3$ 
UPPER ORDOVICIAN BRACHIOPODS FROM KAZAKHSTAN
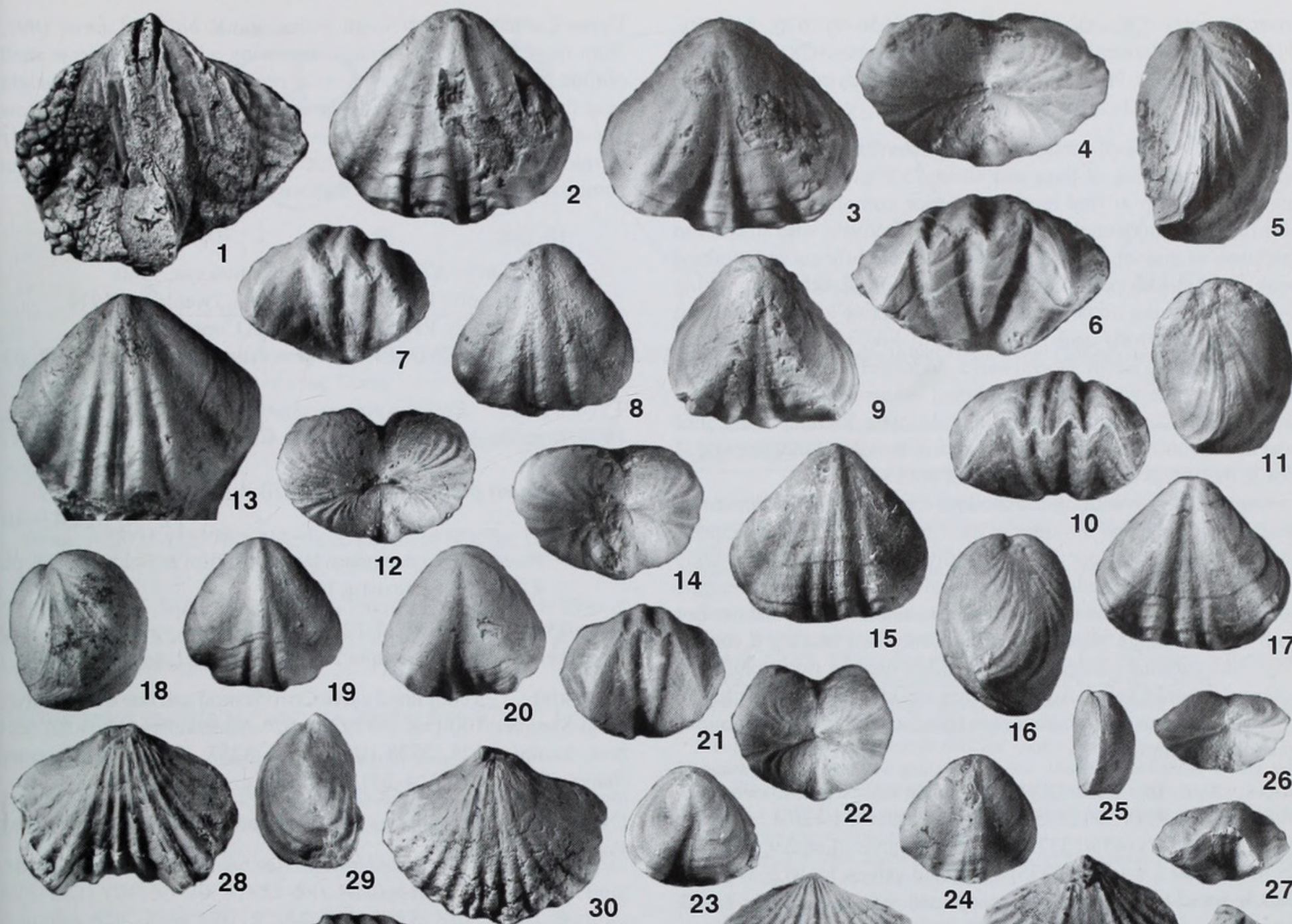

15
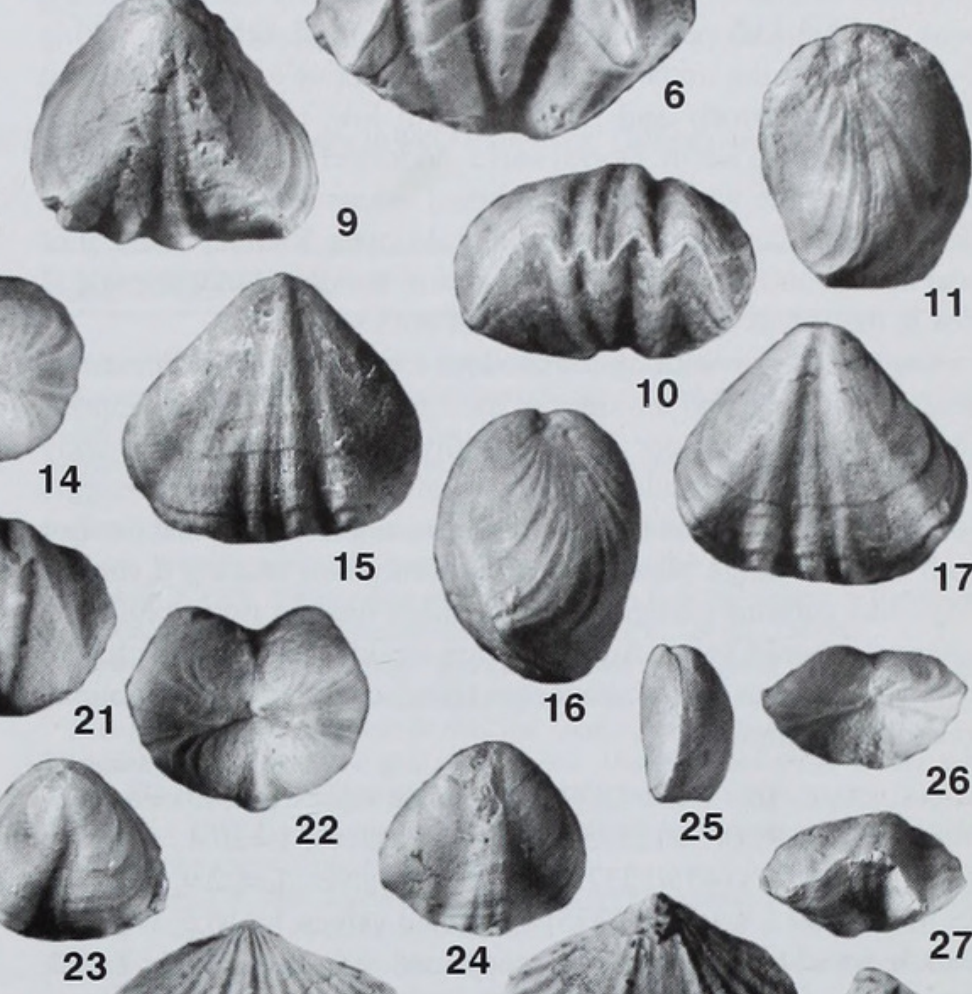
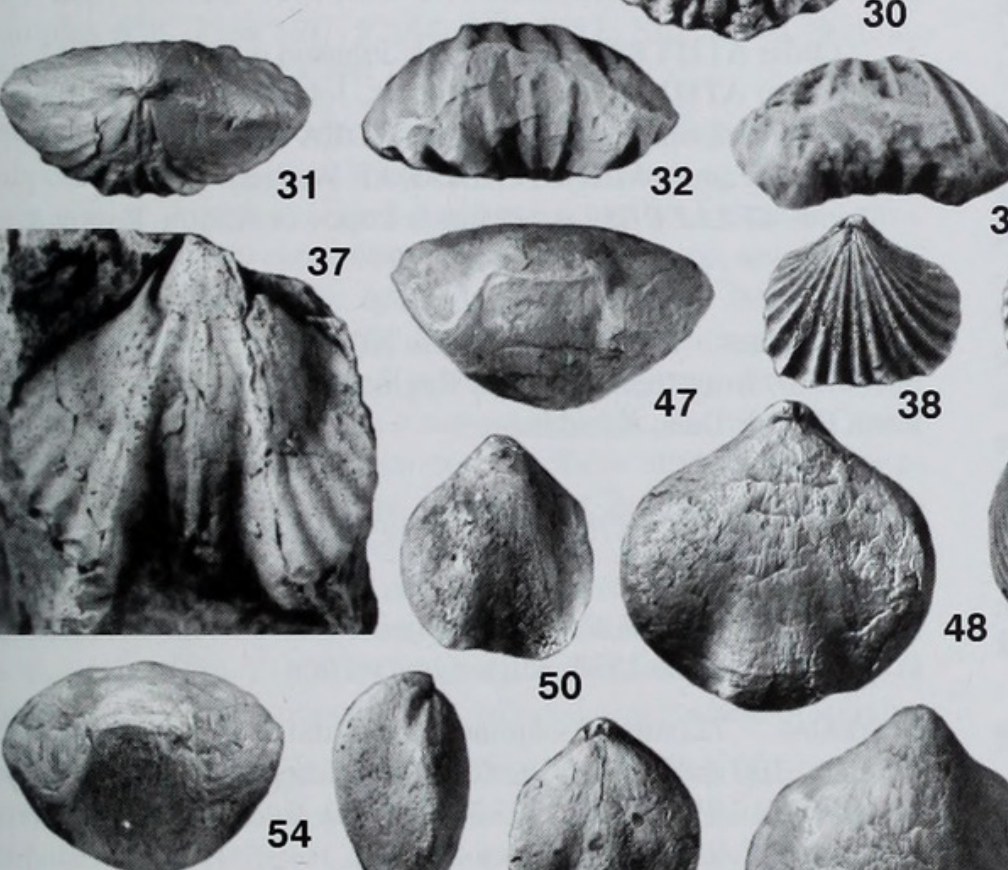

54
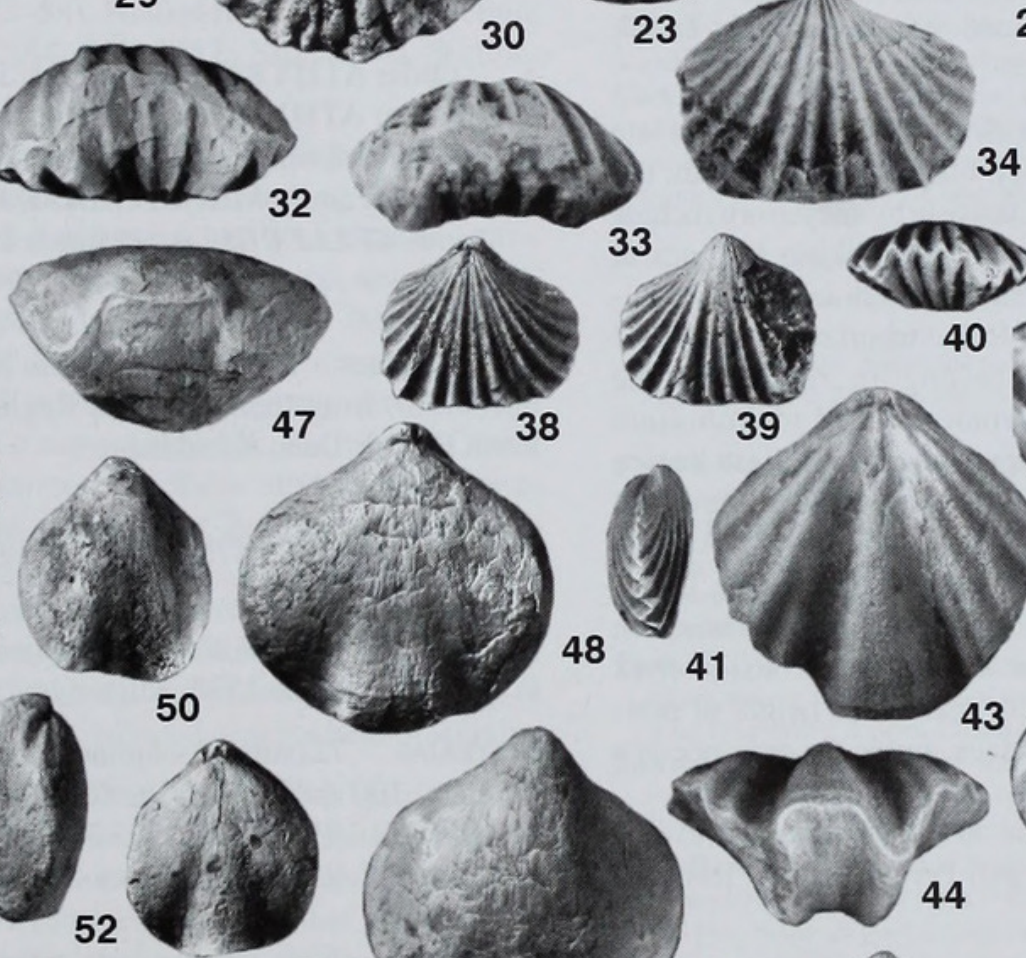

34
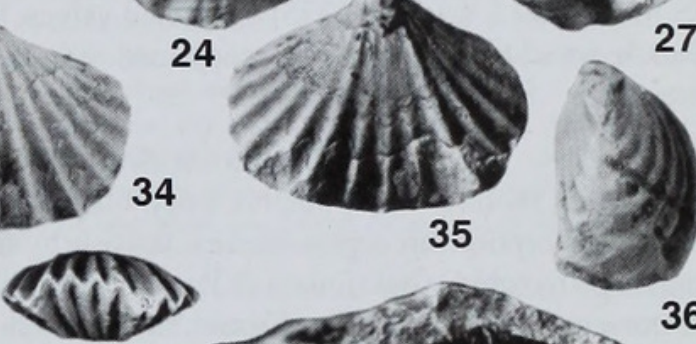

$40-159620$ 36 38
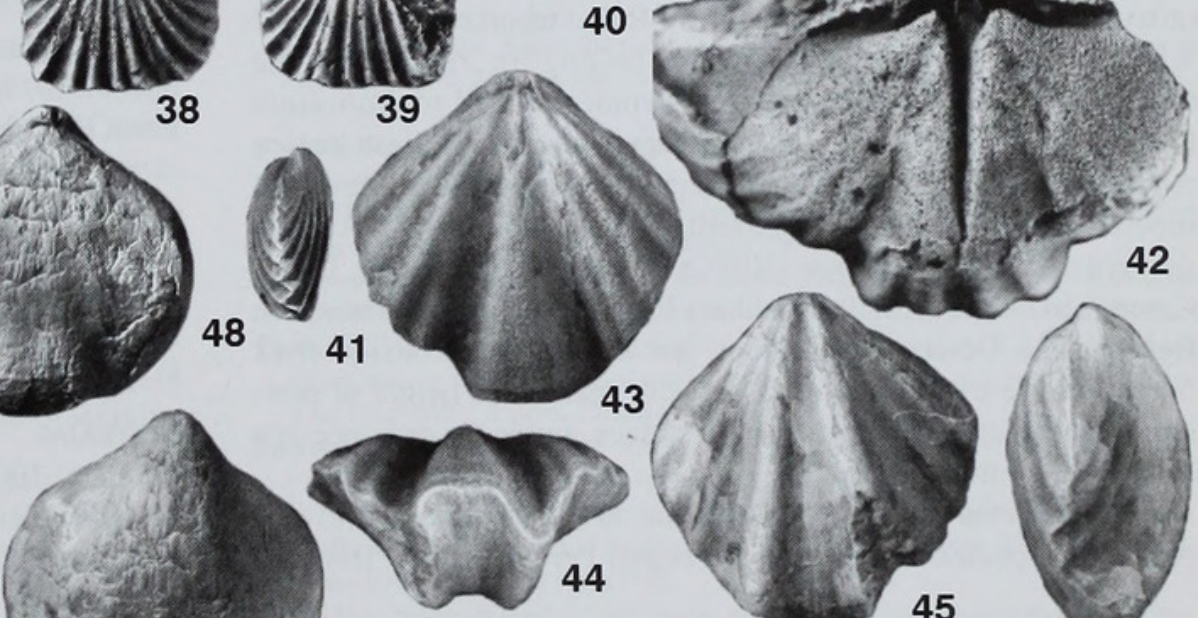
48
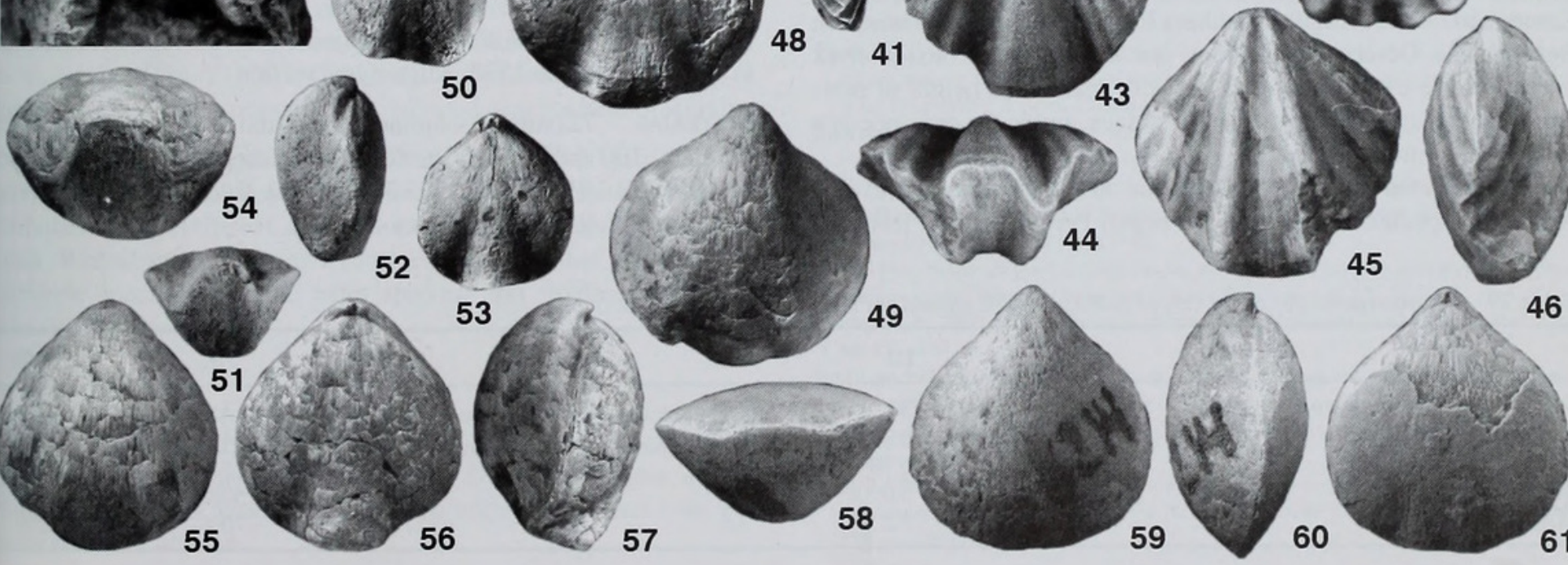
from Samples 100 (=K-98/1970) (BC 56656-9), 626, 843 (BC 57581-83), Anderkenyn-Akchoku section; Samples 628 (BC 56661), 2538 (BC 57580), 7613 (BC 56649-55), Kujandysai Section; Sample 948 (BC 57311-2), Tesik River.

DESCRIPTION. Shell dorsibiconvex to biconvex, slightly transverse, about $73 \%$ as thick as long and about $75 \%$ as long as wide with maximum width at mid-length. Anterior commissure uniplicate. Ventral valve moderately convex in lateral profile with maximum thickness at quarter valve length from the slightly curved, pointed beak. Delthyrium open, narrow triangular. Ventral sulcus originating 2-3 mm from the umbo, very shallow posterior to mid-valve, but deepening anteriorly and terminating in low, trapezoidal tongue about $79 \%$ valve width. Dorsal valve moderately and evenly convex in lateral profile with shallow umbonal sulcus inverting into a low flattened median fold with steep lateral slopes. Radial ornament of coarse angular ribs, usually with 4 ribs in the dorsal median fold, 3 ribs in the sulcus and 6-8 on flanks of both valves.

Ventral interior with cyrtomatodont teeth and short, thin dental plates flaring close to the sides of the valve. A pedicle base impression occupies the floor of the delthyrial cavity; large, weakly impressed ventral muscle field with small, lanceolate adductor scars completely surrounded by diductor scars anteriorly. Dorsal interior with disjunct hinge plate and narrow cruralium bearing a simple, ridge-like cardinal process and long, high median ridge extending anteriorly to mid-valve. Adjustor scars weakly impressed with posterior and anterior pair of about equal size, separated by fine, oblique transmuscle ridges.

MEASUREMENTS. (471/12375) conjoined valves, $\mathrm{L}=14.0, \mathrm{~W}=16.9$, $\mathrm{T}=6.3, \mathrm{Sw}=8.9 ;(474 / 12375)$ conjoined valves, $\mathrm{L}=20.4, \mathrm{~W}=21.0$, $\mathrm{T}=11.2, \mathrm{SW}=8.7 ;(475 / 12375)$ conjoined valves, $\mathrm{L}=22.9, \mathrm{~W}=24.5$, $\mathrm{T}=10.2, \mathrm{Sw}=12.8 ;(476 / 12375)$ conjoined valves, $\mathrm{L}=16.5, \mathrm{~W}=19.8$, $\mathrm{T}=6.5, \mathrm{Sw}=11.2 ;(479 / 12375)$ conjoined valves, $\mathrm{L}=10.5, \mathrm{~T}=6.7$, $\mathrm{Sw}=6.7$.

DiscUSSION. Rhynchonellides are widespread in the mid and late Ordovician shallow-water benthic assemblages of Kazakhstan, but with few exceptions are represented exclusively by ancystrorhynchids and oligorhynchids (Nikiforova \& Popov 1981; Nikitin \& Popov in Klenina et al. 1984). All other Kazakh rhynchonellide species previously described as Rhynchotrema by Rukavishnikova (1956) and Klenina (in Klenina et al.1984) belong in reality to the ancystrorhynchid Altaethyrella or atrypides related to Nalivkinia (Popov et al. 2000). This species represents the earliest known record of rhynchonellides with the cruralium supported by the dorsal median septum in Kazakstan. Externally it is similar to Rostricellula sarysuica Nikitin \& Popov (Nikitin et al. 1996) from the Upper Caradoc to Lower Ashgill Dulankara Regional Stage of the northern Betpak-Dala Desert, Kazakhstan, but differs in the less convex lateral profile of the dorsal valve, with maximum height at midlength, the relatively shallow ventral sulcus, and in the presence of a ridge-like cardinal process.

Rhynchotrema akchokense is similar in radial ornament to two Australian species of the genus, $R$. oepiki Percival, 1991, from the
Upper Caradoc of New South Wales, and R. bailliei Laurie, 1991, from the Caradoc of Tasmania, in having a more transverse shell outline, a less convex dorsal valve profile, with maximum height near the mid-length, a relatively shallow ventral sulcus and a low dorsal median fold. $R$. bailliei is also characterized by its poorly developed cardinal process, which makes its generic assignment somewhat questionable, although we refer it to Rhynchotrema.

Order ATRYPIDA Rzhonsnitskaya, 1960

Superfamily LISSATRYPOIDEA Twenhofel, 1914

Family PROTOZYGIDAE Copper, 1986

Genus PECTENOSPIRA Popov, Nikitin \& Sokiran, 1999

TYPE SPECIES. Pectenospira pectenata Popov, Nikitin \& Sokiran, 1999, from the Anderken Formation, Chu-Ili Range.

\section{Pectenospira pectenata Popov, Nikitin \& Sokiran, 1999}

Pl. 14, figs $43-46$

1999 Pectenospira pectenata Popov, Nikitin \& Sokiran: 648, pl. 4, figs 21-32, text-fig. 10 .

Holotype. CNIGR 23/12986, conjoined valves, from the Anderken Formation, Sample 2538, Kujandysai section.

MATERIAL. 23 conjoined valves, two ventral and one dorsal valve, from Samples 100 (=K-98/1970), 626 Anderkenyn-Akchoku section; Samples 628, 2538 (BC57363), 8257, Kujandysai Section; Sample 948 (BC 57314-20), Tesik River.

Discussion. This species was described and discussed in detail by Popov et al. (1999).

Order ATHYRIDIDA Boucot, Johnson \& Staton, 1964 Suborder ATHYRIDIDINA Boucot, Johnson \& Staton, 1964 Superfamily MERISTELLOIDEA Waagen, 1883 Family MERISTELLIDAE Waagen, 1883

Genus KELLERELLA Nikitin \& Popov in Nikitin, Popov \& Holmer, 1996

TYPE SPECIES. Kellerella ditissima Nikitin \& Popov in Nikitin et al. (1996), from the Dulankara Regional Stage (Upper Caradoc), north Betpak-Dala, Kazakhstan.

\section{Kellerella misiusi Popov, Nikitin \& Sokiran, 1999}

Pl. 14, figs 58-61

HoLOTYPE. CNIGR 26/12986, conjoined valves from the Anderken Formation, Sample 2538, Kujandysai section.

MATERIAL. 72 pairs of conjoined valves and one dorsal valve, from Samples 100 (=K-98/1970), 626, Anderkenyn-Akchoku section; Sample 8214 (BC56773, 57334-9), west side of Aschisu River; Samples 628, 2538, Kujandysai Section.

Table 29 Measurements of ventral valves of Nikolaispira guttula sp. nov., Sample 948, Tesik river.

\begin{tabular}{lcccccccc}
\hline & $\mathrm{L}$ & $\mathrm{W}$ & $\mathrm{T}$ & $\mathrm{Ld}$ & $\mathrm{Sw}$ & $\mathrm{St}$ & $\mathrm{L} / \mathrm{W}$ & $\mathrm{T} / \mathrm{L}$ \\
\hline $\mathrm{N}$ & 13 & 13 & 13 & 13 & 13 & 13 & 13 & 13 \\
$\mathrm{X}$ & 6.5 & 5.6 & 4.2 & 6.0 & 2.9 & 1.2 & $117 \%$ & $64 \%$ \\
$\mathrm{~S}$ & 0.72 & 0.57 & 0.66 & 0.70 & 0.45 & 0.29 & 5.2 & 5.1 \\
MIN & 5.6 & 4.9 & 2.8 & 5.0 & 2.2 & 0.5 & $110 \%$ & $50 \%$ \\
MAX & 7.6 & 6.7 & 5.3 & 7.2 & 3.6 & 1.6 & $127 \%$ & $70 \%$ \\
\hline
\end{tabular}



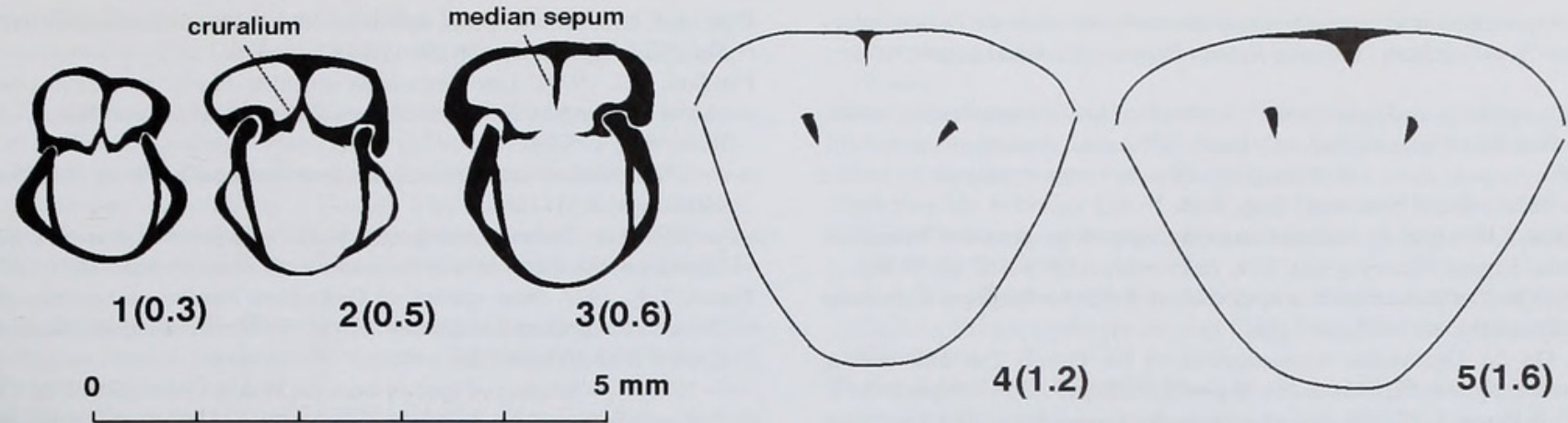

Fig. 21 Transverse serial sections of Nikolaispira guttula sp. nov., 1-3, BC 57588; 4-5, BC 57589, Sample 948, Tesik River. Distance in mm is measured from the posterior tip of ventral beak. Dorsal valve uppermost.

Discussion. This species was described and discussed in detail by Popov et al. (1999).

\section{Genus NIKOLAISPIRA Nikitin \& Popov in Nikitin, Popov \& Holmer, 1996}

TYPE SPECIES. Nikolaispira rasilis Nikitin \& Popov in Nikitin $e t$ al., 1996, from the Dulankara Regional Stage (Upper Caradoc), north Betpak-Dala, Kazakhstan.

\section{Nikolaispira guttula sp. nov. $\quad$ Pl. 14, figs 47-57; Fig. 21}

ETYMOLOGY. After guttula, Latin - small drop.

HOLOTYPE. BC 57585, Pl. 14, figs 50-53, conjoined valves, from the Anderken Formation, Sample 2538, Kujandysai section.

MATERIAL. 38 conjoined valves from Samples 100 (=K-98/1970), 626, 8221 (BC 56770, 37857-58), Anderkenyn-Akchoku section; Samples 628, 2538 (BC 57584, 85), 8257, Kujandysai Section; Sample 948 (BC 57588, 89), Tesik River.

DESCRIPTION. Shell smooth, ventribiconvex, slightly elongate, subpentagonal in outline, about $64 \%$ as thick as long and $117 \%$ as long as wide. Anterior commissure parasulcate. Ventral valve profile strongly and evenly convex with maximum thickness near the midvalve. Delthyrium small, open, narrow triangular. Beak slightly acuminate, erect posteriorly. Shallow ventral sulcus originating slightly posterior of the mid-valve, flanked by two low, rounded plications and terminating in a narrow, semicircular tongue. Dorsal valve gently convex with maximum thickness slightly posterior to mid-length. Median fold low and narrow, originating near midvalve. Ventral interior with delicate teeth and short, thin dental plates placed closely to the lateral sides of the valve. Dorsal interior with small cruralium on a thin, long median septum extending anteriorly to mid-valve (Fig. 21). Spiralia laterally directed comprising up to three whorls. Jugal processes short, situated near the bese of spiralia.

DisCUSSION. This species differs from Nikolaispira rasilis Nikitin \& Popov (in Nikitin, Popov \& Holmer 1996), which occurs in the Dulankara Stage (Upper Caradoc to Lower Ashgill) of north BetpakDala, Kazakhstan, in having a more elongate outline, like the most elongate specimens of the latter species, and smaller number of whorls of the spiralia.

ACKNOWLEDGMENTS. We thank Rong Jia-yu (Nanjing) for discussion on Chinese material and M.G. Bassett for helpful comments on the manuscript. LEP acknowledges support from the Royal Society of London and the National Museum of Wales. LRMC acknowledges travel funds from The Natural History Museum.

\section{REFERENCES}

Amsden, T.W. 1968. Articulate brachiopods of the St.Clair Limestone (Silurian), Arkansas, and the Clarita Formation (Silurian), Oklahoma. Memoirs of the Paleontological Society, 1: 1-117

Apollonov, M. K. 1975. Ordovician trilobite assemblages of Kazakhstan. Fossils and Strata, 4: $375-380$.

Bancroft, B.B. 1933. Correlation tables of the stages Costonian-Onnian in England and Wales. Privately printed, Blakeney, Gloucestershire; 4 pp.

Barrande, J. 1879. Systeme Silurien du Centre de la Boheme, Volume 5, Classe des Mollusques, Ordre des Brachiopodes. Prague \& Paris, 226 pp., 153 pls.

Bondarev, V.I. 1968. Stratigraphy and characteristic brachiopods of the Ordovician deposits of southern Novaya Zemlya, the island of Vaigach and northern Pai- Khoi Nauchno-Issledovatelskii Institut Geologii Arkitiki (NIIGA) Trudy, 157: 3-144.

Borissiak, M.A. 1956. The genus Kassinella. Materiali vsesoyuznovo nauchnoissledovatelskii Geologisckeskova Instituta, Moskva, 12: 50-52.

Boucot, A. J. 1975. Evolution and extinction rate controls. Developments in Paleontology and Stratigraphy, 427 pp., Elsevier, Amsterdam.

Chernyschev, T.N. 1887. Fauna of the middle and upper Devonian of the western slopes of the Urals. Trudy Geolicheskovo Komiteta, St Petersburg, 3: 1-208.

Chugaeva, M. N. 1958. Trilobites from the Ordovician of Chu-Ili Range. Trudy geologicheskogo Instituta Akademii Nauk SSSR, Moscow, 9: 5-138.

Cocks, L.R.M. 2001. Ordovician and Silurian global geography. Journal of the Geological Society, London, 158: 197-210.

_ \& Rong Jia-yu 1988. A review of the late Ordovician Foliomena brachiopod fauna with new data from China, Wales, and Poland. Palaeontology, 31: 53-67, pls 8 ,

- \& - 1989. Classification and review of the brachiopod Superfamily Plectambonitacea. Bulletin of the British Museum (Natural History), London, Geology, 45: 77-163.

- \& - 2000. Strophomenida. In Kaesler, R. (ed.) Treatise on Invertebrate Paleontology, H, Brachiopoda (Revised). Volume 2, University of Kansas Press: 216 348.

Cooper, G.A. 1956. Chazyan and related brachiopods. Smithsonian Miscellaneous Collections, 127:1-1245, pls 1-269.

— \& Kindle, C.H. 1936. New brachiopods and trilobites from the Upper Ordovician of Perce, Quebec. Journal of Paleontology, 10: 348-372.

Davidson, T. 1883. A Monograph of the British Fossil Brachiopoda, Vol. V, Silurian Supplement, part 2: 135-242, pls 8-17. Palaeontographical Society Monographs.

Etter, W. 1999. Community Analysis: 285-360. In Harper, D. A. T. (ed.) Numerical palaeobiology. Computer-based modelling and analysis of fossils and their distributions. John Wiley \& Sons, Chichester \& New York, 468 pp.

Foerste, A.F. 1909. Preliminary notes on Cincinnatian fossils. Bulletin of the Denison University Scientific Laboratories, 14: 209-228, pl. 4

1912. Strophomena and other fossils from Cincinnatian and Mohawkian horizons, chiefly in Ohio, Indiana and Kentucky. Bulletin of the Denison University Science Laboratories, 17: 17-173, pls 1-8.

1914. Notes on the Lorraine faunas of New York and the province of Quebec Bulletin of the Denison University Science Laboratories, 17: 247-328, pls 1-5.

Fortey, R. A. 1997. Late Ordovician trilobites from southern Thailand. Palaeontology, 40: $451-459$.

Fu Li-pu 1982. Brachiopoda. In Xian Institute of Geology and Mineral Resources (ed) Paleontological Atlas of Northwest China, Shaanxi-Gansu-Ningxia Volume, Part 1, Precambrian and Early Paleozoic. Geological Publishing House, Beijing: 95-178, pls $30-45$

Hall, J. 1847. Palaeontology of New York, vol. 1. Containing descriptions of the organic remains of the lower division of the New-York System. van Benthuysen, New York. 338 pp., 100 pls. 
- 1859. Observations on genera of Brachiopoda. Contributions to the Palaeontology of New York, New York State Cabinet of Natural History, $12^{\text {th }}$ Annual Report, Albany: 8-110.

1860. Observations on Brachiopoda. Contributions to the Palaeontology of New York, New York State Cabinet of Natural History, $13^{\text {th }}$ Annual Report, Albany: 65-75 1883. Brachiopoda plates and explanations. New York State Geologists $2^{\text {nd }}$ Annual Report for 1882. Albany, New York. 17pp., 6 pls.

— \& Clarke, J.M. 1892. An introduction to the study of the genera of Palaeozoic Brachiopoda. Natural History of New York, Palaeontology, 8: 1-367, pls 1-20.

Havlícek, V. 1950. The Ordovician Brachiopoda from Bohemia. Rozpravy Ústredniho ústavu geologického, 13: 1-72, pls 1-13.

- 1952. On the Ordovician representatives of the Family Plectambonitidae (Brachiopoda). Sbornik Ústredniho ústavu geologického, 19: 397-428, pls 1-3.

Holmer, L.E. \& Popov, L.E. 2000. Class Lingulata. In, Kaesler, R. (editor), Treatise on Invertebrate Paleontology, Vol. H, Brachiopoda (Revised), Vol. 2: 30-146. University of Kansas Press.

Jin Jisuo \& Copper, P. 1997. Parastrophinella (Brachiopoda); its paleogeographic significance at the Ordovician/Silurian boundary. Journal of Paleontology, 71: 369 380.

Jones, O.T. 1928. Plectambonites and some allied genera. Memoirs of the Geological Survey of Great Britain, Palaeontology, 1: 367-527, pls 21-25.

Kaesler, R. (editor). 2000. Treatise on Invertebrate Paleontology, Vol. H, Brachiopoda (Revised), Vols 2, 3. University of Kansas Press. 919 pp.

Keller, B.M. 1956. General survey of the Ordovician stratigraphy of the Chu-Ili Mountains. In, Ordovician of Kazakhstan, Part I, Nauk, Alma-Ata

Khalfin, L. L. 1958. Plastinchatozhabernyye mollyuski Chu-Iliiskikh gor [Bivalved molluscs of Chu-Ili mountains]. Trudy geologicheskogo Instituta Akademii Nauk SSSR, 9:139-156, pls 1-7. [In Russian.]

Klenina, L.N., Nikitin, I.F. \& Popov, L.E. 1984. Brachiopods and biostratigraphy of the Middle and Upper Ordovician of the Chinghiz Ranges. Nauka, Alma-Ata. 196 pp., pls 1-20.

Kolobova, I.M. \& Popov, L.E. 1986. Faunal characteristics of the Middle Ordovician Anderken Regional Stage in the Chu-Ili Range (Southern Kazakhstan). Ezhegodnik Vsesojuznogo Paleontologicheskovo Obshchestva, 29: 246-261.

Koren, T.N., Lytochkin, V.N., Popov, L.E. \& Tolmacheva, T.J. 1993 Biostratigraficheskii analiz pelagicheskikh strukturno-veshchestvennykh komplexoy paleozoja dlja tselej GSR-50 i-200. VSEGEI, St Petersburg, 79 pp

Kutorga, S.S. 1848. Ueber die Brachiopoden-Familie der Siphonotretaceae. Russich Kaiserliche Mineralogische Gesellschaft zu St.Petersburg Verhandlungen [for 1847] 250-286, pls 6,7.

Laurie, J.R. 1991. Articulate brachiopods from the Ordovician and Lower Silurian of Tasmania. Association of Australasian Palaeontologists Memoir, 11: 1-106.

Melou, M. 1990. Brachiopodes articules de la Coupe de l'Isle de Rosan (Crozon, Finistère); Formation des Tufs et Calcaires de Rosan (Caradoc-Ashgill). Geobios, 23 539-560, pls $1-10$

Misius, P.P. \& Ushatinskaya, G.T. 1977. New Ordovician and Silurian strophomenids from Kazakhstan and northern Kirgiz. Novye Vidy Drevnikh Rastenii i Bespozvonochnykh SSSR, 4: 113-116

Neuman, R. B. 1971. An early middle Ordovician brachiopod assemblage from Maine New Brunswick and northern Newfoundland. Smithsonian Contributions to Paleobiology, 3: 113-124, pls 1,2

Nikiforova, O.I. \& Popov, L.E. 1981. New species of Ordovician rhynchonelloids from Kazakhstan and Central Asia. Paleontologeski Zhurnal, 1981: 54-67.

Nikitin, I.F. 1972. The Ordovician of the Chingiz Range. Nauka, Alma-Ata: 126-166, pls 13-20.

1973. The Ordovician of Kazakhstan, Part 2, Palaeogeography, Palaeotectonics Nauka, Alma-Ata, 100 pp.

— , Apollonov, M. K., Tsai, D. T., \& Rukavishnikova. T. B. 1980. Ordovician System: 44-78. In, Abdulin, A. A. (editor) Chu-Iliiskii rudnyi poyas. Part 1. Geologiya Chu-Iliiskogo regiona. Nauka, Alma-Ata.

_, Frid, N. M. \& Zvontsov, V. S. 1991. Paleogeography and main features of volcanicity in the Ordovician of Kazakhstan and North Tien-Shan, Geological Survey of Canada Paper, 90 (9): 259-270.

- Gnilovskaya, M.B., Zhuravleva, I.T., Luchinina, V.A. \& Myagkova, E.I. 1974. Anderken bioherm range and history of its origin. Trudy Instituta Geologii i Geofyziki (IGIG), Akademii Nauk SSSR, Sibirskoe Otlodenie, 84: 122-159

— \& Popov, L.E. 1983. Middle Ordovician orthides and plectambonitaceans from the northern Pri-Ishim and the Akzhar River Basin in central Kazakhstan (brachiopods) Ezhegodnik vsesoyuznovo Paleontologicheskovo Obshchestva, 26: 228-247, pls 1-3.

— \& 1985. Ordovician strophomenids (Brachiopods) from north Priishim (central Kazakhstan). Ezhegodnik vsesoyuznovo Paleontologicheskovo Obshchestva, 28: $34-49$, pls $1-3$

— $\&$ - 1996. Strophomenid and triplesiid brachiopods from an Upper Ordovician carbonate mound in central Kazakhstan. Alcheringa, 20: 1-20.

—_ — \& Holmer, L.E. 1996. Late Ordovician brachiopod assemblage of HibernoSalairian type from Central Kazakhstan. GFF, 117: 83-96.

Nikitina, O.I. 1985. A new brachiopod association from the Middle Ordovician of southern Kazakhstan. Paleontologeski Zhurnal, 1985 (4): 21-29
Öpik, A.A. 1939. Brachiopoden und Ostrakoden aus dem Expansusschiefer Norwegens. Norsk Geologisk Tidsskrift, 19: 117-142, pls 1-6.

Percival, I.G. 1979a. Late Ordovician articulate brachiopods from Gunningbland, central western New South Wales. Proceedings of the Linnean Society of New South Wales, 103: 175-187

1979b. Ordovician plectambonitacean brachiopods from New South Wales. Alcheringa, 3: 91-116.

- 1991. Late Ordovician articulate brachiopods from central New South Wales. Memoirs of the Association of Australasian Palaeontologists, 11:107-177.

Popov, L.E. 1977. New species of Ordovician inarticulate brachiopods from the Chinghiz Range (East Kazakhstan). Novye Vidy Drevnik Rastenii i Bespozvonochnych SSSR, 4: 102-105, pls 1,2.

1980. New brachiopod species from the Middle Ordovician of the Chu-Ili Hills. Ezhegodnik Vsesoyuznovo Palaeontologicheskovo Obshchestva, 23: 139-158.

1985. Brachiopods of the Anderken horizon of the Chu-Ili Hills (Kazakhstan). Ezhegodnik Vsesoyuznovo Palaeontologicheskovo Obshchestva, 28: 50-68, pls 1-3.

, Nikitin, I.F. \& Cocks, L.R.M. 2000. Late Ordovician brachiopods from the Otar Member of the Chu-Ili Range, Kazakhstan. Palaeontology, 43: 833-870, pls 1-6.

- $\&$ Sokiran, E.V. 1999. The earliest atrypides and athyridides (Brachiopoda) from the Ordovician of Kazakhstan.Palaeontology, 42: 625-661, pls 1-4.

Potter, A.W. 1991. Discussion of the systematic placement of the Ordovician brachiopod genera Cooperea and Craspedelia by Cocks and Rong (1989). Journal of Paleontology, 65: $742-755$.

Reed, F.R.C. 1905. New fossils from the Haverfordwest district IV. Geological Magazine, 5: 433-436, 444-454, pls 14, 23.

Rong Jia-yu, Harper, D. A. T., Zhan Ren-bin \& Li Rong-yu 1994. KassinellaChristiania Associations in the early Ashgill Foliomena fauna of South China Lethaia, 27: 19-28.

—, Zhan Ren-bin \& Harper, D. A. T. 1999. Late Ordovician (Caradoc-Ashgill) brachiopod faunas with Foliomena based on data from China. Palaios, 14: 412-431

Rouault, M. 1850. Note preliminaire sur une nouvelle formation découverte dans le terrain Silurien de la Bretagne. Bulletin de la Societé géologique de France, (2) 7 : 724-744

Rukavishnikova, T.B. 1956. Ordovician brachiopods from Kazakhstan. Trudy Akadeemia Nauk SSSR Geologicheskii Institut, 1: 105-168, pls 1-5.

Sapelnikov, V.P. \& Rukavishnikova, T.B. 1975. Upper Ordovician, Silurian and Lower Devonian pentamerids of Kazakhstan. Nauka, Moscow. 226 pp., 43 pls.

Schuchert, C. \& Cooper, G.A. 1931. Synopsis of the brachiopod genera of the suborders Orthoidea and Pentameroidea, with notes on the Telotremata. American Journal of Science, (5), 22: 241-255.

_ \& 1932. Brachiopod genera of the suborders Orthoidea and Pentameroidea. Memoirs of the Peabody Museum of Natural History, 4: 1-270, pls 1-29.

— \& LeVene, C.M. 1929. Brachiopoda (generum et genotyporum index et bibliographia). In, Pompeckj, F. (ed.) Fossilium Catalogus, Vol. 1, Animalia, Pars 42. Junk, Berlin. 140 pp.

Sengor, A.M.C. \& Natalin, B.A. 1996. Paleotectonics of Asia: fragments of a synthesis. In, Yin, A. \& Harrison, M. (eds) The tectonic evolution of Asia. Cambridge University Press: 486-640.

Severgina, L.G. 1967. New species and genera of Ordovician brachiopods from the Sayano-Altai Hill District. Nekotoryie Voprosy Geologii Zapadnoi Sibiri, 63: 120 140 , pls $1-5$

1978. Brachiopods and stratigraphy of the Upper Ordovician of the Gornoi Altai, Salair and Gornoi Shoria. Trudy Akademiia Nauk SSSR, Sibirskoe Otdelenie, Institut Geologii i Geofyziki (IGIG), 405: 3-41.

Sharpe, D. 1848. On Trematis, a new genus belonging to the family of brachiopodous Mollusca. Quarterly Journal of the Geological Society of London, 4: 66-69.

Sinclair, G.W. 1945. Some Ordovician lingulid brachiopods. Transactions of the Royal Society of Canada, 39: 55-82, pls 1-4

Sowerby, J. de C. 1839. Shells. In, Murchison, R.I. The Silurian System. John Murray, London: 579-712, pls 1-29

Stukalina, G.A. 1988. Studies in Paleozoic crinoid-columnals and stems. Palaeontographica, A204: 1-66, pls 1-15

Toporova, R.P., Malitskii, N.P., Mikhailov, N.P. \& Moskaljeva, N.V. 1971. Magmatizm i metamorfism, Chu-Baikashskii Rayon. Geologya SSSR, 40 (2): $34-46$.

Tsai, D. T. 1976. Graptolity srednego ordovika Kazakhstana [Graptolites of the Middle Ordovician of Kazakhstan]: 76 pp. Nauka, Alma-Ata [In Russian].

Ulrich, E.O \& Cooper, G.A. 1936a. New Silurian brachiopods of the family Triplesiidae. Journal of Paleontology, 10: 331-347, pls 48-50.

$-1936 \mathrm{~b}$. New genera and species of Ozarkian and Canadian brachiopods. Journal of Paleontology, 10: 616-631

Wang Yu 1949. Maquoketa Brachiopoda of Iowa. Geological Society of America Memoir, 42: 1-55, pls 1-12.

Weber, V. N. 1948. Trilobity siluriiskikh otlozhenii SSSR. Vyp. 1. Nizhnesiluriiskie trilobity [Trilobites of the Silurian deposits of USSR. Vol. 1. Lower Silurian trilobites.]. Monografii po paleontologii SSSR, 69: 1-113. [In Russian]

Whittington, H.B. \& Williams, A. 1955. The fauna of the Derfel Limestone of the Arenig District. Philosophical Transactions of the Royal Society of London, B238: $397-430$, pls $1-3$ 
Williams, A. 1962. The Barr and Lower Ardmillan Series (Caradoc) of the Girvan District, southwest Ayrshire. Geological Society of London Memoir, 3: 1-267, pls 125.

1963. The Caradocian brachiopod faunas of the Bala District, Merionethshire Bulletin of the British Museum (Natural History), Geology, 8: 327-471, pls 1-16 - 1974. Ordovician Brachiopoda from the Shelve District, Shropshire. Bulletin of the British Museum (Natural History), Geology Supplement, 11: 1-163, pls 1-28.

- Lockley, M.G. \& Hurst, J.M. 1981. Benthic palaeocommunities represented in the Ffairfach Group and coeval Ordovician successions of Wales. Palaeontology, 24 661-694.

Wright, A.D. \& Jaanusson, V. 1993. New genera of Upper Ordovician triplesiid brachiopods from Sweden. Geologiska Foreningens i Stockholm Forhandlingar, 115 93-118.

Xu Han-kui, Rong Jia-yu \& Liu Di-yong 1974. Ordovician brachiopods. In, Nanjing
Institute of Geology and Palaeontology, Academia Sinica (editors), Handbook of Stratigraphy and Palaeontology in Southwest China, Beijing, 144-154, pls $64-66$ (in Chinese)

Zeng Quing-luan 1987. Brachiopoda. In, Wang Xiao-feng et al, Biostratigraphy of the Yangste Gorge Area 2, Early Palaeozoic Era. Geological Publishing House, Beijing. 614 pp (English summary pp. 489-555), pls 8-18

Zhan Ren-bin \& Cocks, L.R.M. 1998. Late Ordovician brachiopods from the South China Plate and their palaeogeographical significance. Special Papers in Palaeontology, 59: 1-70, pls 1-9.

— \& Rong Jia-yu 1995. Four new Late Ordovician brachiopod genera from the Zhejiang-Jiangxi border region, east China. Acta Palaeontologica Sinica, 34: 549 574, pls $1-4$

Ziegler, A.M., Cocks, L.R.M. \& Bambach, R.K. 1968. The composition and structure of Lower Silurian marine communities. Lethaia, 1: 1-27. 


\section{$2 \mathrm{BHL}$ Biodiversity Heritage Library}

Popov, L E, Cocks, L R M, and Nikitin, I F. 2002. "Upper Ordovician brachiopods from the Anderken Formation, Kazakhstan: their ecology and systematics." Bulletin of the Natural History Museum. Geology series 58, 13-79. https://doi.org/10.1017/s0968046202000025.

View This Item Online: https://www.biodiversitylibrary.org/item/113713

DOI: https://doi.org/10.1017/s0968046202000025

Permalink: https://www.biodiversitylibrary.org/partpdf/140860

\section{Holding Institution}

Natural History Museum Library, London

\section{Sponsored by}

Natural History Museum Library, London

\section{Copyright \& Reuse}

Copyright Status: Public domain. The BHL considers that this work is no longer under copyright protection.

This document was created from content at the Biodiversity Heritage Library, the world's largest open access digital library for biodiversity literature and archives. Visit BHL at https://www.biodiversitylibrary.org. 